\title{
Considerações sobre a Sacralização do Cânon e a Canonização da Crítica
}

\author{
Jean Pierre Chauvin
}

Ensaios sobre Letras Luso-Brasileiras, Historiografia Literária e Retórica Musical, submetidos ao Concurso para obtenção do título de Livre-Docente em Editoração, na Escola de Comunicações e Artes da Universidade de São Paulo.

São Paulo

2021 


\section{Advertência}

Este volume contém três seções.

$\mathrm{Na}$ primeira (Perspectiva Crítica), propõe-se uma discussão em torno do chamado Arcadismo Brasileiro, descrito nos manuais sobre Historiografia Literária produzidos no Brasil desde a primeira metade do século XIX. O capítulo envolve a preparação de aulas para a disciplina Cultura e Literatura Brasileira (ministrada para os alunos do curso de Editoração, no Departamento CJE, da ECA), a atuação no programa de Pós-Graduação na FFLCH e o projeto de pós-doutorado, desenvolvido entre 2019 e 2020 na Escola de Filosofia, Letras e Ciências Humanas da UNIFESP (Campus Guarulhos).

A segunda parte (Registros) contempla materiais ensaios sobre a historiografia das letras. Os artigos têm por objeto sermões de Antônio Vieira e produções de poetas luso-brasileiros que viveram entre os séculos XVII, XVIII e XIX. A seção final (Excurso) contém um estudo de Poética Musical aplicado ao Requiem de Mozart.

Este livro reproduz a tese de livre-docência examinada pela Comissão Julgadora em 24 de fevereiro de 2021, na Escola de Comunicações e Artes da Universidade de São Paulo. Sou muito grato a Marisa Midori Deaecto, Sílvia Maria Azevedo, Maria Augusta da Costa Vieira, Pedro Puntoni e Mônica Isabel Lucas pela atenta e generosa acolhida dos textos.

J.P. C. 


\section{Sumário}

I-Perspectiva Crítica

1. A Construção do Arcadismo Brasileiro

II - Estudos

2. Revisão de Bento Teixeira. Revista Todas as Musas, São Paulo, v. 10, n. 1, pp. 71 $87,2018$.

3. "Pictórico", Categoria do Seiscentos? Revista Teresa (FFLCH/USP), n. 18, São Paulo, pp. 133-149, 2018.

4. Hierarquia e Adulação em Antônio Vieira. Publicado na Revista Remate de Males (UNICAMP), Campinas, em 2020.

[80]

5. A Expulsão dos Jesuítas como Lugar-Comum. In: FRANCO, José Eduardo et al (orgs.). Jesuítas e Ilustração: Rupturas e Continuidades. São Leopoldo: Editora Unisinos, 2019, pp. 272-298.

6. Retrato de Anarda ou A Lira Aguda de Manuel Botelho de Oliveira. Revista Opiniães (FFLCH/USP), São Paulo, n. 6/7, pp. 237-250, 2016.

7. A Conquista de Goa, Exercício Poético [inédito]

8. Marquês de Pombal, Arauto do Segundo Império (Brasileiro)? e-Letras com Vida. Revista de Humanidades e Artes (CLEPUL/FCT), n. 4, Lisboa, pp. 129-142, 2020.

9. Lei, Argumento e Arte no Uraguay [inédito]

10. Revisão do Caramuru [inédito]

11. Retórica, Controvérsia do Oitocentos. Revista Patrimônio \& Memória (CEDAP/UNESP), Assis, v. 13, n. 2, pp. 14-27, 2017.

12. (Anti)retórica em Gonçalves de Magalhães. Revista Grapho (UFPB), v. 21, n. 2, pp. 28-41, 2020.

III - Excurso

13. Ut Musica Poesis: leitura do Requiem de Mozart (1791). Submetido à revista Cerrados (UnB), em 2020. 
I - PERSPECTIVA CRÍTICA 
Quando Anarda me desdenha afetos de um coração, é diamante Anarda? não, não diamante, porque é penha (Manuel Botelho de Oliveira) $^{1}$

A meus olhos dão recreio Um monte, um vale, uma penha; A cascata que entre rochas Com ruído se despenha (Marquesa de Alorna) $^{2}$

Aqui bramando, um rio se devolve, Qual serpente feroz medo incutindo; Co'uma arcada de pedra o homem cobre-o; Ele a derruba? - Nova arcada o doma (Gonçalves de Magalhães) $^{3}$

1 “Comparações no rigor de Anarda". In: Música do Parnaso, 2005, pp. 23-24 [org. por Ivan Teixeira].

2 "[Cantiga] LXXI". In: Obras Poéticas, Tomo II, 1844, p. 311.3

3 “Deus, e o Homem”. In: Suspiros Poéticos e Saudades, 1986, p. 83. 


\title{
A Construção do "Arcadismo Brasileiro"
}

\author{
JPC - Você não quer se sentar? \\ JAH - Não, não. Isso não é uma carteira; é uma barreira. Eu não furo greve. ${ }^{4}$
}

\section{Arcádia}

Em 1995, Jorge Antonio Ruedas de la Serna questionava o menor interesse dos estudiosos brasileiros em abordar as letras produzidas durante o chamado Arcadismo. Para o pesquisador mexicano, isso se devia ao fato de a poesia daquele período carregar ambiguidade estilística e política, em adesão à hipótese formulada por Antonio Candido em Formação da Literatura Brasileira, em 1959.

No ano seguinte, Ivan Teixeira propôs-se a abordar aspectos sincrônicos e diacrônicos da poesia árcade, com ênfase na produção de Basílio da Gama. Em 1997, Joaci Pereira Furtado questionou o emprego de termos imprecisos em manuais de literatura brasileira, que haviam sedimentado a imagem de que os homens letrados que ocuparam ou passaram pelas vilas da capitania de Minas Gerais teriam sido despertados pelo sentimento nativista. Inventados como poetas dotados de gênio, sua obra se confundira com a trajetória ambígua entre a burocracia cortesã e a denúncia versificada. A discussão, no âmbito das letras, foi complementada por Marco Antonio Silveira que, no mesmo ano, discutiu a composição estratificada de Vila Rica, em que o esforço de se distinguir social e politicamente justificaria, em parte, o empenho dos bacharéis em se distinguir numa estrutura orientada por um sem número de códigos, leis e preceptivas.

Quarenta anos após Formação da Literatura Brasileira ser publicada, Ivan Teixeira volta ao cenário nacional com o impressionante Mecenato Pombalino e Poesia Neoclássica: obra decisiva para que se reavaliasse os textos produzidos sob a lupa da Inquisição, o poder de Sebastião José de Carvalho e Melo e as preceptivas vigentes naquele tempo. Em 2001, Alcir Pécora incluiu o relevante capítulo "Amor à Convenção", em torno da poesia de Silva Alvarenga, em Máquina de Gêneros. Mais dois anos se passam, até que a Revista USP publica o dossiê Brasil Colônia, tema do 53ํ número do

\footnotetext{
${ }^{4}$ Diálogo na Unifesp Guarulhos, diante de uma pilha de carteiras em frente à sala 207, com João Adolfo Hansen, em 4.X.2019, por volta das 9h25.
} 
periódico, com várias colaborações em torno das matérias ditas coloniais, com destaque para os artigos de Luciana Gama e Ricardo Martins Valle - este, no ano anterior à conclusão de sua tese de doutorado em torno de Cláudio Manuel da Costa.

De lá para cá tornou-se mais difícil (se não constrangedor) ignorar ou desprezar os estudos relacionados à poesia e às artes produzidas durante o século XVIII, no Estado do Brasil. Além dos trabalhos relacionados, chamam atenção os estudos realizados por Luiz Eduardo Oliveira (na Universidade Federal do Sergipe), em profícua parceria com José Eduardo Franco, em Portugal. Mais recentemente, devem ser mencionadas a dissertação de mestrado (2017) e a tese de doutorado realizadas por Caio César Esteves de Souza, que descobriu poemas inéditos atribuídos a Alvarenga Peixoto.

Esta pesquisa deve muito a esses estudos. Neste trabalho, discutem-se textos líricos que vieram a ser classificados imprecisamente como "árcades", nos florilégios, coletâneas e manuais de literatura brasileira escritos a partir do século XIX. Para evitar o anacronismo, pretende-se situar e caracterizar de outro modo a poesia produzida no universo luso-brasileiro, entre a segunda metade do Setecentos e a primeira metade do Oitocentos, o que implica percorrer versos produzidos por numerosos homens letrados que viveram aquém e além-mar naquele período. Durante a pesquisa, serão cotejadas as edições em que os textos foram publicados. Para melhor discorrer sobre a matéria, o trabalho concentrar-se-á em três vértices: 1. Revisão da historiografia "literária" lusobrasileira, especialmente aquela feita no país; 2 . Resgate de leis, preceptivas, tratados de cortesania e congêneres, que circularam nas possessões do reino português durante os séculos XVII e XVIII; 3. Análise de obras produzidas em Portugal e no Estado do Brasil, durante o período.

Sobre o terceiro item, recupero o que disse Evaldo Cabral de Mello (2002, p. 15): “[Em 1822,] os nacionalistas não éramos nós, mas os portugueses de Portugal que, dentro e fora das Cortes de Lisboa, clamavam contra o que Ihes parecia a escandalosa inversão de papéis pela qual o Brasil transformara-se no centro da monarquia lusitana, relegando a metrópole à posição de colônia". A poesia atribuída aos homens letrados do Setecentos será considerada como texto e pretexto para ilustrar a tentativa de filiação à auctoritas (modelos colhidos na tradição greco-latina, medieval e moderna), e claro, discorrer sobre os usos da retórica e da poética nos versos produzidos, sob a túnica eclesiástica e o manto Real (KANTOROWICZ, 1997). Recorrer-se-á, também, a 
certos dogmas embasados ao direito canônico e às penas previstas pelas Ordenações, sob o reinado hispano-português de Filipe II (vigentes nas "partes" do reino desde 1603), também como forma de sugerir o caráter protocolar aplicado aos poemas e à performance dissimulada dos homens letrados ${ }^{5}$, durante o período - que não tinha relação com "nativismo", nem envolvia "espontaneidade" de sentimentos "inspirados" pela natureza local.

\section{Arcadismo}

O "Arcadismo" (ou aquilo que a palavra representava em meados do século XIX) é termo controverso. De acordo com os autores que nossa geração consultava nos tempos de colégio", ele traduzia uma etapa, "pré-romantismo", e constituía um movimento com feição "antilusitana", situado entre 1768 (ano de publicação das Obras, de Cláudio Manuel da Costa) e 1808 (chegada da família real, que fugira das tropas francesas, em novembro de 1807); ou esticado até 1823 (quando foi publicada a declaração de Independência, assoprada em setembro de 1822, de um córrego, pelo majestoso Pedro I); ou mesmo, 1836 - quando se publicou o manifesto romântico na revista Niterói, redigido por um grupo de jovens brasileiros sob a tutela de Gonçalves de Magalhães, a respirar "patrioticamente" os ares de Paris.

Via de regra também desaprendíamos, com a ajuda de manuais compactos, mas totalizantes, que um punhado de poetas-burocratas (HESPANHA, 2006; SCHWARTZ, 2011; STUMPF, 2014; ATALLAH, 2016; SOUZA, 2016) e mineradores (BOXER, 1963; SOUZA, 2017b) que circularam entre Vila Rica, Lisboa, Coimbra, e Roma, durante a segunda metade do século XVIII, estariam ligados à assim chamada "Inconfidência Mineira" - "movimento" que teria permitido à certa historiografia ufanista confundir os papéis do alferes conhecido como Tiradentes, durante os atos de contestação a medidas implementadas pelo governo local, sob o aval da Coroa. Como se sabe, demorou muito

\footnotetext{
${ }^{5}$ Como percebeu Ricardo Martins Valle (2003, p. 119), ao ler Cláudio Manuel da Costa, “A fábula inventa a criação de um rio, nascido de uma pedra, desentranhada de uma terra, que mais tarde sustentará os cuidados dos homens presentes. O mito inflete duas quedas, a do pai e a própria, e três numes atuam, como machina, sobre a tragédia: Júpiter, Apolo e Amor. Para aquela civilização regida pelas ordenanças régias, as potências do concerto e do desconcerto do mundo se sustentavam sobre os atributos dessas três deidades pagãs as quais deviam servir de ornamentos ao documento dos versos de Cláudio".

${ }^{6}$ Refiro-me, em particular, ao manual de José de Nicola (Língua, Literatura \& Redação. São Paulo: Scipione, 1989), fatiado em três volumes.
} 
tempo até que Kenneth Maxwell ${ }^{7}$ sugerisse outra denominação para o movimento, deflagrado e descoberto em 1789.

No que diz respeito às letras produzidas naquele tempo, hoje se sabe que se atribuíram sentidos bem diversos em relação àqueles pretendidos pelos poetas em seus versos, na segunda metade do Setecentos. Joaci Pereira Furtado sintetizou-o em estudo incontornável sobre a recepção às cartas satíricas, atribuídas a Tomás Antônio Gonzaga:

A recepção das Cartas Chilenas [...] é um bom exemplo do quanto a leitura pode falar do leitor - ou às vezes mais do que do próprio texto. Escrita às vésperas da Inconfidência Mineira, fato mais tarde içado à condição de momento fundador da nacionalidade brasileira, as "cartas" de Critilo se confundem com a conjura, sob a maioria dos olhos que percorreram seus versos entre 1845 e 1989. Porta-voz dos conspiradores, anunciador da revolta iminente ou testemunha de uma situação irrevogavelmente condenada ao desfecho insurrecional, o poeta refletiria de alguma forma o contexto da conjuração (FURTADO, 1997, p. 32).

Desde o final da década de 1980, o maior interesse no que se passara na capitania das Minas, duzentos anos antes, não permitia conciliar a aparente "sinceridade" e "brasilidade" dos escritores com a sua linguagem artificial. Até então, mal se levava em consideração o fato de os homens letrados ocuparem altos postos na administração reinol: prevalecia a postura de viés pseudorrevolucionário. Tampouco compreendíamos por que aqueles tipos enalteciam o bucolismo, se viviam na cidade. Em termos culturais, quase nunca se aprofundavam aproximações entre a produção dos poetas árcades luso-brasileiros e as obras atribuídas a Teócrito, Virgílio (LOPES, 1997b), Horácio (TEIXEIRA, 1999), Petrarca, Sannazaro (MARNOTO, 1996), Camões, Correia Garção (SERNA, 1995) etc.

No período de 1960 a 1990, dois métodos ganharam força. De um lado, sobrevalorizava-se a literatura produzida no país a partir do Oitocentos e atribuía-se aos textos da "era colonial" o papel de prenúncios, de "manifestações" antecipadas do que se fez "honestamente" e "sem regras" a partir do Romantismo. Salvo raras exceções, o lastro "evolutivo" dessa vertente crítica eram os manuais da historiografia tradicional. Suas matrizes remontavam a Januário da Cunha Barbosa (1829), Francisco Adolfo de

\footnotetext{
${ }^{7}$ Cf. A devassa da devassa (2001), em que o historiador sugere atribuir o nome de "Conjuração Mineira".
} 
Varnhagen (1850), Sílvio Romero (1888), João Ribeiro (1906), José Veríssimo (1916), Ronald de Carvalho (1919) etc.

Em outro grupo, constituído entre 1980 e 1990, propunha-se aproximação bem diferente. Esses pesquisadores passaram a considerar os aspectos históricos, protocolos de leitura, a aplicação de preceptivas, a emulação de modelos pelos poetas lusobrasileiros, os meios de circulação oral/escrita (DAHER, 2018) - razão pela qual valorizam a "materialidade" e o "suporte" textual - de que fala Roger Chartier (2017), com que objetivam reconstituir a "primeira legibilidade" dos textos, como defende João Adolfo Hansen (1989; 2004; 2013) e confirmam Alcir Pécora (1994; 2001), Adma Muhana (1997), Maria do Socorro Fernandes de Carvalho (2007), Marcello Moreira (2013), entre outros.

Além de evitar o uso de conceitos e categorias anacrônicas, há que se levar em conta não a pretensão de "verdade" (quase sempre um decalque biográfico a partir dos versos que o poeta tivesse, muito narcisicamente, legado para a posteridade), mas a filiação dos homens letrados aos modelos que emula; o respeito aos códigos ao compor versos; os protocolos de leitura; a produção oral e circulação de poesia e outros gêneros. Desde então, leva-se em conta a forma mentis, a civilidade, a memória e o repertório cultural daqueles homens letrados, devolvidos ao seu tempo, circunstância e lugar.

Evidentemente, esse modo de ver não se restringe aos pesquisadores daqui. Para mencionar um exemplo, no estudo sobre a Arcadia, de Jacopo Sannazaro, Rita Marnoto (1996, p. 23) relembrava que:

Num universo que se rege por normas muito claras e peremptórias, e onde todos os acontecimentos giram em torno de um núcleo semântico bem definido, não é de admirar que atitudes e situações se repitam quase inalteradas em vários momentos diacrónicos da evolução do género, dando lugar a inúmeros topoi: o lupus stabulis, o pastor que procura a ovelha perdida, o repouso na hora da canícula o que encontra a sua correspondente, ao nível textual, na prática da citação literária. A evocação de gestos milenares, que se repetem desde os primórdios da humanidade, está para a reutilização das formas literárias através das quais esse mesmo gesto foi dito - o que faz do texto bucólico um encadeado de outros textos.

Como se se tratasse de um movimento menos relevante e avulso - espécie de alavanca metafórica que (pré)acionasse a roda positivista da história dita "nacional", o 
"Arcadismo" luso-brasileiro também era percebido como uma espécie de intermezzo ilustrado - mas também despótico e carola - entre o obscurantismo "barroco" e a "sinceridade" romântica ${ }^{8}$. A despeito das constantes alusões à tradição poética de outros tempos, não éramos estimulados a estabelecer relações entre o movimento e a região de Arcádia, na Grécia antiga, figurada por Teócrito, Virgílio ou Sannazaro.

Será adequado propor uma transição nos estudos em torno desse período, nas Letras luso-brasileiras? A partir da década de 1990, as pesquisas relativas ao movimento "árcade" perderam o caráter panorâmico e concentraram-se na trajetória de um menor número de poetas. Quer dizer, são trabalhos de teor monográfico, com recortes mais específicos. O sobrevoo da periodização cedeu lugar à leitura vertical, nem sempre isenta de equívocos tomados de empréstimo ao ideário pseudocientífico, formulado ao longo do século XIX e repisado, pelo menos, até a década de 1970.

Por razões óbvias, o poeta árcade não poderia prever a independência do Brasil em relação à Coroa, tampouco conceber que os seus versos constituiriam um degrau da excelsa historiografia pátria, que se pretendia "nacionalista", apesar de depender economicamente da Inglaterra havia mais de um século ${ }^{9}$. Seria igualmente ingênuo supor que o "árcade" se contrapusesse visceralmente contra a estética do "Barroco". Ricardo Martins Valle (2003, p. 107) chamou atenção para o suposto entrelugar ocupado por Cláudio Manuel da Costa, segundo incerta crítica:

Os que situam Cláudio entre "barroco" e "árcade" supõem deduzir do "Prólogo ao Leitor" tal esquema. Partindo do prólogo, em 1805, Bouterwek, o primeiro leitor da cadeia de sua recepção, já considerara Cláudio um dos introdutores de "um estilo mais nobre na poesia portuguesa", se bem que ainda transparecesse "a poesia empolada dos sonetistas do século XVII", do "marinismo português". Seu

\footnotetext{
8 "Obviamente, a racionalidade do eu poético das liras é só uma construção verossímil, isto é, retórica; no caso, essa verossimilhança não pretende apenas parecer verdadeira, como é típico da representação seiscentista da experiência humana no grande teatro do mundo em que a hierarquia define uma máscara social para cada um. Como construção retórica, a representação do eu poético nas liras de Gonzaga também resulta da aplicação de um efeito, ou de uma verossimilhança, mas é um efeito que deseja ser lido como falta de efeito, como se a poesia fosse representação direta de uma experiência universal da verdade que dispensa a retórica, nas exposições de um eu magistral que vai ensinando a Marília as verdades de uma humanidade ilustrada [...]" (HANSEN, 1997, p. 46 - grifo do autor).

9 “Além de suas amplas leituras e observações pessoais, [Sebastião José de] Carvalho e Melo apercebeuse do controle que a Inglaterra exercia sobre Portugal - não só em função das dificuldades econômicas e sociais de sua pátria como pelo rápido progresso da economia britânica. Acreditava ele que o tratado cromwelliano de 1654 estabelecera em Portugal, recém-independente, um sistema de controle que o tornara mais escravizado aos interesses britânicos do que o jamais o fora aos da Espanha. Os ingleses tinham obtido a posse sem o domínio" (MAXWELL, 2001, p. 23).
} 
esquema, porém, foi reproduzido por Sismondi, Garrett, Varnhagen, Sílvio Romero, José Veríssimo, Antonio Candido, etc.

Quando teria começado o "Arcadismo" nas partes do Brasil? Exceção feita aos volumes do Movimento Academicista, de José Aderaldo Castello (1969), até a década de 1990 não se considerava que, quarenta e quatro anos antes do marco "didático" 1768 ("início do movimento árcade" no "Brasil"), havia sido fundada na capitania da Bahia a Academia Brasílica dos Esquecidos, que teve no historiador Sebastião da Rocha Pita um dos sete ilustres membros, "O Acadêmico Vago". Rocha Pita compunha poemas laudatórios, muito deles dirigidos aos colegas da agremiação. Essa informação poderia despertar maior interesse nos estudantes de nosso tempo, tendo em vista o diálogo entre a cultura, as práticas sociais e a concepção portuguesa sobre o Estado do Brasil, meio século antes da escalada e esgotamento do ouro, nas Minas:

Ao longo da primeira metade do século XVIII, o movimento academicista ajudou a desencadear uma nova percepção sobre o estatuto político do território colonial, estimulando, assim, a reflexão sobre a natureza dos laços que prendiam a América ao Reino: amarras simultaneamente jurídicas, familiares, linguísticas, econômicas e culturais. Tal percepção da natureza dos vínculos entre Colônia e Metrópole não se cristalizou de maneira linear, homogênea ou definitiva, dado que os colonos portugueses na América compreendiam a si próprios com extensão do corpo místico ${ }^{10}$ imperial lusitano (KANTOR, 2004, p. 16).

\section{Persona}

É sintomático que, algum tempo, não tivéssemos maior contato com o “Arcadismo", durante a graduação. Entre 1995 e 1998, saltávamos de Antônio Vieira para os versos ora lacrimosos, ora cômicos, de Álvares de Azevedo; e da sátira atribuída a Gregório de Matos para o humour à inglesa e com acento francês, de Machado de Assis. Depois deles, praticamente ignorávamos José de Alencar, Raul Pompeia, escutávamos apenas menções a Aluísio Azevedo e desembocávamos, cheios de pseudo-

\footnotetext{
${ }^{10}$ Durante a Idade Média, Igreja e Reinos disputaram a primazia de serem os representantes primordiais do Corpo Místico, como sugeria o apóstolo São Paulo, na primeira epístola aos Coríntios. Somente a partir do século XII, o Vaticano e os reis chegaram a um acordo relativo ao emprego de "corpo místico", como fusão das alçadas espiritual e temporal, repartidas entre Estado e Igreja (Cf. Ernst Kantorowicz, 1981).
} 
rebeldia burguesa, nos versos de Oswald, Mário, Bandeira, Drummond, Murilo e Cabral, para finalmente perder qualquer sobra de autossuficiência, ao lidar, "mire veja", com a prosa rosiana, os sonetos de Glauco Mattoso etc.

Para além das controvérsias em torno da estética, ideologia, ou movimento "árcade(s)", retroalimentadas não exclusivamente em livros didáticos destinados ao ensino médio, haveria que se repensar o lugar daquela vertente nas letras lusobrasileiras, produzidas na segunda metade dos Setecentos. A sociedade colonial se conduzia de modo cifrado. Em parte, porque seguia rigorosamente as leis do reino; mas também porque os súditos temiam a Deus e reforçavam, sempre que possível, a vassalagem fidedigna à mitra papal e ao trono português ${ }^{11}$.

Sobretudo, a elite letrada era ciosa de certos modos de como se deveria falar, vestir-se, comportar-se, agir e habitar. Rodrigo Bentes Monteiro observou que, imediatamente após a Guerra dos Emboabas, entre 1709 e 1710, a administração da capitania tratou de aclimatar o casario e os edifícios públicos ao contorno da paisagem citadina.

[...] parece ter sido prática corrente no império ultramarino português a adaptação de estruturas administrativas às diversidades próprias das características regionais, adaptação já sentida na construção das cidades em harmonia com a paisagem - o que curiosamente associava a geografia física do lugar à sua vida social - e no apaziguamento das forças conflitantes ao término da Guerra dos Emboabas (MONTEIRO, 2002, p. 294).

Num universo supostamente ditado por Deus, codificado pela etiqueta e regrado em acordo com as vontades do Rei (na forma de cartas-régias, forais, alvarás, leis extravagantes etc) ${ }^{12}$, era de se esperar que os versos produzidos por aquele punhado de membros da elite luso-brasileira dialogassem, em alguma medida, com a postura, os

\footnotetext{
11 “Estabeleceu-se em Portugal, na verdade, um arranjo particular do 'processo civilizatório'. Ser civilizado dependia do título adquirido ou do papel desempenhado na estrutura burocrático-patrimonialista; porém, significava, acima de tudo, ser um 'bom vassalo' e um 'bom cristão'." (SILVEIRA, 1997, p. 49).

12 “[...] as tendências de caráter centralizador e de reforçamento do poder metropolitano, que buscavam ampliar as bases da empresa colonizadora, marcaram as medidas político-administrativas adotadas pelo Estado português a partir de 1640. Na primeira metade do século XVIII essas tendências intensificaramse com o impulso da atividade mineradora. Após 1760 , com o declínio na extração de metais, somado à redução das rendas régias em vários setores da economia colonial, a tônica centralista foi ampliada e se intentou uma racionalização administrativa mais eficaz, como alternativa para viabilizar a continuidade das práticas mercantilistas na Colônia" (SALGADO, 1985, p. 61).
} 
modos e as ações adotadas pelos "homens bons" do lugar: fidalgos, súditos (submetidos) ao cetro real, fidelíssimos ao absolutismo político e moral (TOCQUEVILLE, 2017; ELIAS, 2001 e 2011; BURKE, 1994; REVEL, 2009; ANDERSON, 2016). Versejar constituía um dos pré-requisitos reservados aos homens letrados que viviam nas partes do reino. ${ }^{13}$ Vitorino Magalhães Godinho afirmava que:

Sob a hierarquia, legalmente fixada, há uma constante tensão com as realidades sociais em mudança; mas a ordem tradicional defende-se com a promulgação de medidas constrangentes, e apega-se às distinções. [...] as pessoas inscrevem-se imediatamente em categorias que se distinguem pelo nome, pela forma de tratamento, pelo traje e pelas penas a que estão sujeitas (GODINHO, 1971, p. 58).

Marco Antonio Silveira (1997, p. 30) observou que, "Ao lado dos apelos da etiqueta, toda uma prática social definida pelos excessos de violência e licenciosidade compunha também o cotidiano da nobreza - além, é claro, de perpassar a sociabilidade dos grupos populares". Como os historiadores assinalaram (SILVA, 1997; ARAÚJO, 2008), uma das contradições fundamentais dos homens que viveram durante o século XVIII residia no fato de constituírem uma

[...] nobreza profundamente mercantilizada [...] os grupos de mercadores e negociantes buscam por todos os meios integrar-se na ordem nobiliárquica: a realidade é o mercador-cavaleiro e o cavaleiromercador, o fidalgo-negociante e o negociante-enobrecido, não sendo por isso fácil a existência de uma burguesia autônoma, com seus valores próprios (GODINHO, 1971, p. 84).

No que se refere aos textos produzidos em Vila Rica, Lisboa, Coimbra, Angola ou Moçambique, não há sentido em atribuir aos "pastores" figurados em verso o papel de

\footnotetext{
13 "Apesar das variadas classes sociais existentes no interior do Império lusitano, o que definia primordialmente a participação no grupo dirigente era o prestígio; daí o fato de a sociedade portuguesa apresentar uma estratificação estamental. Tal prestígio, capaz de conferir 'nobreza' aos membros do estamento, cada vez menos, durante a época moderna, constituía privilégio exclusivo das antigas famílias proprietárias de terra. Pelo contrário, à proporção que as conquistas no Ultramar avançavam e tornavase mais evidente que a economia lusa era eminentemente mercantil, os títulos honoríficos e a incrustação na máquina administrativa afirmavam-se como meios de distinção. Ambos os caminhos, afinal, aproximavam do rei. De outro lado, todo o aparato estético, valorativo e comportamental relativo à honra apresentava-se como indispensável na definição do lugar de cada um na sociedade" (SILVEIRA, 1997, pp. 46-7).
} 
"homens" sensíveis ${ }^{14}$, praticantes de uma poesia confessional; nem sinceros, porque libertos do "cultismo" ou "culteranismo" (COUTINHO, 1984; CANDIDO, 2000) praticado até o século anterior; tampouco "espontâneos" (BOSI, 2001), por abordarem temas insuflados pela natureza, ao calor e segundo o impulso de ditames anímicos. Tratava-se de instâncias de um "eu" figurado, previstas e projetadas como éthos no discurso, em acordo com a conveniência - como recomendavam os manuais de Retórica e Poética, lidos e aplicados pelos homens afeitos à convenção literária, em seu tempo. Por extensão, não há por que classificar essa poesia convencional, produzida na segunda metade do Setecentos, sob o estatuto teleológico de "pré-romântica". ${ }^{15}$

Nas liras de Gonzaga, como se sabe, quase invariavelmente o eu poético constitui a personagem Marília como ouvinte silenciosa de pequenas tramas que formam estórias da experiência passada e projetos de vida futura, de modo que a fala deliberativa de Dirceu também poderia ser caracterizada estilisticamente conforme 0 modelo do gênero tragicômico pastoral doutrinado por Guarani. Sua diç̧ão funde situações narrativas e caracteres de estilo baixo com os de estilo alto (HANSEN, 1997, p. 45).

Tão discutível seria atribuir ao que se produziu na capitania de Minas Gerais, possessão do reino português, prenúncios da formação da cultura e "identidade nacional":

[...] parte importante da tradição crítica brasileira tem reconhecido traços realistas do poeta [Silva Alvarenga], sobretudo por interesse histórico moderno de estabelecê-los como indícios da superação do seu próprio período nas letras coloniais, isto é, mais precisamente, com o intuito de descobrir nos poemas os signos da formação daquilo que posteriormente se definiria como sistema particular de uma literatura nacional (PÉCORA, 2001, pp. 191-192).

\footnotetext{
14 “A recusa da empiria que a caracteriza [lira de Gonzaga] não significa, porém, que recusa o sensível. Ao contrário, porque é aristotélica e horaciana, pressupõe que o sensível é a condição para a experiência do pensamento, só que não aceita como matéria de arte o sensível tal como aparece na experiência imediata dos sentidos, pois ela o quer aristotelicamente selecionado, corrigido e sublimado [...]" (HANSEN, 1997, p. 49).

${ }^{15} \mathrm{O}$ "Romantismo pariu entre nós o indianismo, que foi uma expressão mofina da ambição de construir o que virá posteriormente a ser designado por 'identidade nacional'. Malgrado o Juca-Pirama e o Guarani, as classes dirigentes sentiam-se muito pouco nacionais. Nos anos oitenta do século XIX, um dos estadistas do Império, Martinho Campos, mineiro, declarava em pleno recinto do Parlamento que os brasileiros éramos 'os portugueses da América, da mesma maneira pela qual ao tempo da Independência chamávamos os americanos de 'ingleses da América'." (MELLO, 2002, p. 18).
} 


\section{Cânone}

Como se disse, a historiografia das letras luso-brasileiras deve um tanto a Jorge Antonio Ruedas de la Serna, professor da Universidade Autônoma do México. Ele foi responsável pela primeira tradução para o Espanhol de Marília de Dirceu, de Tomás Antônio Gonzaga (1744-1810), publicada simultaneamente no México e no Brasil em 2002. Jorge de la Serna foi orientado por Antonio Candido e, sob sua supervisão, publicara sete anos antes um trabalho muito relevante sobre o "Arcadismo" lusobrasileiro.

De fato, em Arcádia: Tradição e Mudança (1995), ele chamava atenção para o fato de aquela escola literária ter sido pouco estudada no país, embora se tratasse de um período fascinante de "nossa" história cultural, com poetas de talento que dialogavam não apenas com a tradição greco-latina ${ }^{16}$ (Homero, Virgílio, Teócrito, Horácio), mas também com Petrarca e Camões, sem contar os letrados contemporâneos (dos "brasileiros") que viviam além-mar: Correia Garção, Filinto Elísio, Bocage etc.

A tese de Ruedas de la Serna contribui para a rediscussão da poesia setecentista, arena cuja interpretação continua a dividir críticos e historiadores da banda de cá. A esse respeito, ele parecia situar-se em posição ambivalente, a oscilar entre o biografismo (supostamente aplicável aos versos de Tomás Antônio Gonzaga) e a suspeita de que a poesia, convenção que especialmente era, devia muito às preceptivas e códigos de cortesania que circularam entre a chamada Antiguidade e o século XVIII. ${ }^{17}$

Significa que a leitura de Arcádia: tradição e mudança transcorreria sem gerar maiores controvérsias, não fosse a persistência do pesquisador em aplicar conceitos anacrônicos e supostamente "nativistas" nos versos que circularam em Portugal e nas partes do Estado do Brasil, durante a segunda metade do Setecentos. Daí o questionamento procedente de Joaci Pereira Furtado (1998, p. 139), ao discutir o livro

\footnotetext{
${ }^{16}$ É o que também embala a percepção de Fernando Cristóvão (1981, p. 23), formulada na década anterior: "De Virgílio, Teócrito e outros se inspirou sobretudo na contemplação da natureza, na composição do locus amoenus para os seus amores, mas nem lhes tomou o processo de diálogo nem os aspectos úteis da vida no campo. A natureza como quadro e símbolo dos seus sentimentos servia melhor aos seus objetivos".

${ }^{17}$ André Luís Nepomuceno (2002, p. 188) lembra que "Gonzaga, entretanto, era português, a despeito de certas tentativas de críticos românticos de the atribuírem uma identidade colonial definidamente abrasileirada".
} 
de Serna: “[...] o que é a obra da santíssima trindade 'inconfidente"18 - Cláudio, Gonzaga

e Alvarenga - senão a defesa da cultura do colonizador europeu? Como encontrar

autoafirmação 'nativista' numa poesia que decanta as maravilhas da América por aquilo

que ela pode vir a ser igual a Europa?". Conforme salienta Alcir Pécora (2001, p. 192):

Concorre para o mesmo fim de interpretação protonacionalista a notícia de que Silva Alvarenga esteve preso por dois anos sob acusação de envolvimento em conspiração antimonárquica, ao lado de outros companheiros da Sociedade Literária do Rio de Janeiro, da qual era sócio fundador. Tal chave de leitura, marcadamente biográfica e sociológica, aplicada também com frequência aos versos escritos ou publicados posteriormente à prisão daqueles que ficaram conhecidos (e foram assim produzidos, com êxito histórico) como "poetas da Inconfidência" - tal chave de leitura, dizia, torna-se especialmente atraente por encontrar uma brecha de interpretação poética que seja externa à convenção inequivocamente classicizante e universalista adotada por todos os poetas em questão.

Jorge Ruedas de Serna por vezes incorreu em uma análise de cunho impressionista, colada à tradição historiográfica brasileira, em que (re)descobria a "recusa" da parte dos "árcades" aos modelos "obscuros" e "truncados" praticados durante o Seiscentos; a "originalidade" de temas e formas que praticaram; a "sinceridade" dos poetas "espontâneos"19; a "capacidade" dos homens letrados, a ponto de "antecipar" sentimentos, temas e ideologias do Romantismo. ${ }^{20} \mathrm{Em}$ algumas

18 Em Metamorfoses, Edward Lopes reverberava o título dado à coletânea organizada por Domício Proença Filho (A Poesia dos Inconfidentes. Rio de Janeiro: Nova Aguilar, 1996), publicada no ano anterior: “[...] foi aos poetas da Inconfidência que o destino reservou a tarefa de construir os códigos poéticos míticos e figurativos adequados à expressão do 'jeito brasileiro' - o peculiar modo nosso de falar de amor, inclusive, com a graciosidade queixosa e meiga de Gonzaga, com a pungente gravidade do lamurioso Cláudio, com os requebros da malandra brejeirice de Caldas Barbosa, todas, enfim, maneiras de dizer, nos variados registros pedidos pelos diversos momentos do amor" (LOPES, 1997, p. 40).

${ }^{19}$ Contrariando Sílvio Romero, Sérgio Buarque de Holanda (1986, p. 23) foi um dos primeiros a desconfiar da suposta espontaneidade romântica: "Mas essa tradição [romântica] dataria realmente da Escola Mineira? Não seria, ao contrário, a mesma que vamos encontrar, através dos séculos, expressa nas obras mais típicas, mais intensamente representativas do lirismo lusitano? Com efeito jamais se conformou a poesia portuguesa a esse despojamento de todo acidente, de todo transbordamento natural, de toda inocência, tão característico de qualquer arte verdadeiramente clássica".

${ }^{20}$ No "Prólogo" à edição mexicana de Marília de Dirceu, Jorge Ruedas de la Serna (2002, p. 28) mistura as tintas da vida pessoal de Tomás com as virtudes da persona Dirceu: "O Ouvidor se debatia entre uma luta política contra o arbitrário governador Luís da Cunha Meneses, os prazerosos momentos dedicados à poesia e a sua outra luta para ganhar o amor de Marília e o aceite da família, que mantinham seus reparos a um possível matrimônio, pelo poeta tratar-se de pessoa sem fortuna e com grande diferença de idade. Contra esses inconvenientes, Gonzaga esgrimia argumentos poéticos bem autorizados pela tradição clássica. Poder-se-ia dizer que ganhou o coração de Marília com a sedução de seus versos, que se servem com habilidade dos tópicos persuasivos da tradição pastoril". 
afirmações constantes de seu livro, quase podemos escutar a voz de Francisco Adolfo de Varnhagen (1946, p. 346), proclamada um século e meio antes:

Foi Silva Alvarenga quem então introduziu na capital do Brasil, a favor da mocidade estudiosa, o bom gôsto, que graças à literatura franceza começava já a lavrar pela Europa, em vez dos pezados syllogismos dos jesuitas, ou dos affectados conceitos ferteis de antitheses e trocadilhos da escolha que a si mesma se chamou culta. [...] Não se limitaram os esforços de Silva Alvarenga a reformar o gôsto, quanto ao estylo; mas, prevendo já a necessidade de nacionalizar a literatura na America, fez para o conseguir alguns ensaios nos rondós e madrigais.

A afiliação intelectual do pesquisador mexicano a Antonio Candido tê-lo-ia induzido a averiguar, nos "árcades" luso-brasileiros, não a recorrência de gêneros, tópicas, estilos, repertórios lexicais etc., mas a reiterar a fusão entre biografia e verso, reproduzindo a suposta limitação de Tomás Antônio Gonzaga a certos elementos e imagens - dentre elas a do pastor, do prado, do ribeirão, da ovelhinha, da sanfoninha e das pedras. A convenção do tempo é percebida pelo crítico, o que lhe permite aproximar Gonzaga de Virgílio e Correia Garção. Mas isso não o impede de repetir ou propor chaves interpretativas em que sobressai a nota especulativa, em detrimento dos elementos previstos na tradição das Arcádias, que existiam na Europa desde o final do século XVII. ${ }^{21}$

Antonio Candido (2000, p. 84) propusera algo parecido, ao examinar os textos produzidos por Cláudio Manuel da Costa - amigo e correspondente mais próximo de Tomás Antônio Gonzaga. Para o autor de Formação da literatura brasileira, Cláudio teria desenvolvido uma espécie de obsessão pela imagem da "pedra", como sintoma de sua "fixação com o cenário rochoso da terra natal", despertado nele graças ao "anseio profundo de encontrar alicerce". ${ }^{22}$ O crítico não o afirmava gratuitamente: respaldava-

\footnotetext{
${ }^{21}$ Algo parecido se verifica em várias passagens de $A$ Musa Desnuda e o Poeta Tímido, de Luís André Nepomuceno (2002, p. 289) - que manteve contato com Jorge Ruedas de la Serna, em intercâmbio no México -, especialmente quando tenta explicar o êxito popular de Caldas Barbosa: "Em 1775, participava das composições poéticas que celebravam a inauguração da estátua equestre de $D$. José I, na qual estiveram presentes também Silva Alvarenga, Basílio da Gama e Alvarenga Peixoto. A partir de então, Caldas Barbosa contou com privilégio de uma proteção que veio por parte do mecenato de José de Vasconcelos e Sousa [...] Levado por seu protetor, o poeta frequentou a sociedade de corte de Lisboa, Cintra, Belas, Benfica e Bemposta, e obteve sucesso, talvez por sua curiosa mistura de graça cortesã e requebros de mulatismo colonial" (grifos meus).

${ }^{22}$ Na poesia de Cláudio, "As imagens da pedra aparecem em 15 dos 100 sonetos; 2 dos 3 episódios, 1 das seis epístolas; 15 das 20 éclogas, isto é, em 33 de 129 peças, ou seja, quase a quarta parte. Nos 300 sonetos de Diniz aparecem 11 vezes, ou seja, pouco mais da décima parte. Em Garção e Gonzaga a ocorrência é ocasional" (CANDIDO, 2000, p. 84). A leitura de Antonio Candido reverbera na tese de Luis André Nepomuceno (2002, p. 281), para quem Alvarenga Peixoto, "Meio ao estilo de um Cláudio, vê na paisagem
} 
se por uma contabilidade relacionada às variadas formas produzidas pelo poeta. Apesar do apelo quantitativo, a hipótese seria reproduzida por críticos e historiadores que seguiram de perto a sua interpretação, publicada em 1959.

Por sinal, vinte anos depois, o mesmo Antonio Candido reuniu anotações de aula em um livro de cunho didático, ainda popular entre os alunos de graduação. No ensaio "Uma Aldeia falsa" (o segundo de Na Sala de Aula), ele retomava parte do que afirmara em Formação da literatura brasileira. Na leitura de uma longa lira da segunda parte de Marília de Dirceu (1993, p. 31), propunha que os versos fossem analisados como "duas camadas" em tensão. A seu ver, tratava-se de um poema adequado ao "gênero literário pastoral", o que não impediria vislumbrar nele "a verdade biográfica do poeta". ${ }^{23}$ Não seria preciso maior esforço para detectar essa dupla orientação no trabalho de Jorge de Ruedas la Serna (1995, p. 79):

Esse quadro [mundo rústico], no entanto, não é mais que uma alegoria de outra realidade, implícita, e da vida verdadeira do escritor, que é muito diferente, a de um homem culto, refinado, funcionário que, em contraposição a essa paisagem ideal, está vivendo, um drama horrendo na prisão. Assim, só se poderá lograr a compreensão cabal do texto se ao sentido manifesto, alegórico, justapusermos o sentido implícito, oculto, que, no entanto, sustenta o primeiro. Para isso, é necessário que o leitor entre no jogo da convenção, que é o miolo da poesia arcádica.

Esse estado de coisas permitiria discutir algumas questões:

1. Teriam os historiadores da literatura (luso)brasileira desistido de reformular novos juízos em respeito à tradição? Ou não viram necessidade de assim proceder?

\footnotetext{
bruta e primitiva, nas 'brenhas duras' um espaço a ser civilizado pela poesia, pela ciência e pela cultura ilustrada. A colônia é 'bárbara terra, mas abençoada', e seus filhos também são bárbaros, mas, ao mesmo tempo, deixam entrever uma raça de heróis. Curiosa essa frequente antítese na poesia de Alvarenga, entre o primitivismo instituído e a civilização anunciada".

${ }^{23}$ Luís André Nepomuceno (2002, p. 119) supõe que "Cláudio está, de certa forma, diante de um malestar pessoal, como se se sentisse um exilado em sua própria terra. Sente saudades de Portugal, qual fosse sua pátria, porque lá o requinte das leras sobrevive em função da cortesia" (grifos meus). Por sua vez, Djalma Espedito de Lima (2008, p. 23), em Épica de Cláudio Manuel da Costa, esclarece que: "O Vila Rica [...] não é fruto da angústia de um sujeito patriótico e intelectual, consciente da sua inaptidão para usar as fórmulas das descrições do locus amoenus da paisagem arcádica em face das ásperas e duras rochas mineiras, interpretação que se deve a não leitura da aplicação do topos do locus horrendus, não como antecipação romântica, mas como emulação artificiosa da poesia de Tasso e outros".
} 
2. O chamado "Arcadismo" luso-brasileiro continuará a ser caracterizado como movimento cultural (Neoclassicismo) e político (Conjuração Mineira) "localista" e "patriótico", a fomentar um suposto nativismo "brasileiro" avant la lettre?24

3. Aqueles homens letrados (quase todos funcionários da coroa, mineradores e escravocratas) poderiam ser considerados "revolucionários", "libertários", iluministas, pré-burgueses?

4. Os "árcades" penariam de saudade, quando longe de Marília, Nise ou Glaura? Sentiriam falta do "pátrio rio", enquanto flanavam entre Roma e a corte lisboeta?

Uma das consequências dessas redutoras chaves de leitura, ainda encontradas em manuais universitários e apostilas escolares ${ }^{25}$, está no uso de conceitos imprecisos em que a poesia produzida no século XVIII é praticamente descolada da realidade tosca que imperava nos córregos, arraiais e vilas de Minas Gerais.

\section{Decoro}

Uma palavra sobre as correntes teóricas em torno do Arcadismo. O livro de Jorge Antonio Ruedas de la Serna foi resenhado por dois pesquisadores que seriam referências

\footnotetext{
${ }^{24}$ Repare-se no que propunha Almir de Oliveira (1985, p. 33): “Se quisermos remontar aos primórdios da História Brasileira em Minas, encontraremos no incidente entre Borba Gato e Dom Rodrigo de Castel Branco o primeiro indício de desobediência, a primeira afirmação do sentimento de propriedade dos naturais pela terra desbravada. Se é conveniente lembrar, com Hélio Viana, que 'numa Colônia onde a vida se apresentava como uma luta contínua, os motivos econômicos fosse os primeiros a explicar as rebeliões dos seus povoadores', não se deve perder de vista que a sucessão daquelas rebeliões foi formando no espírito dos povos o sentimento de nativismo e, ao influxo de ideias correntes na época, fazendo crescer e expandir-se, a cada dia, o ideal de libertação, de independência" (grifos meus).

${ }^{25} \mathrm{Na}$ "Introdução" às Obras Poéticas de Silva Alvarenga, Fernando Morato secunda, sem questionar, as impressões de Januário da Cunha Barbosa, de 1829: "O cônego Januário diz que depois de liberto Silva Alvarenga se tornou uma pessoa melancólica e sedentária, retomando as aulas e a advocacia, e que foi um aluno quem publicou em 1799 o livro que se tornou o seu mais conhecido: Glaura, poemas eróticos de um americano, porque o próprio poeta não estaria satisfeito com sua obra. $O$ sucesso do volume parece ter sido grande, pois em 1801 saiu a segunda edição" (MORATO, 2005, pp. XXX-XXXI). Um pouco depois dele, Alexei Bueno (2007, p. 42) reaproximou os versos de Dirceu e a mitologia criada em torno de Tomás Antônio Gonzaga, como sintoma prévio do Romantismo: "A lenda do poeta superou a realidade concreta da vida do homem. Marília de Dirceu foi o livro de poesia mais lido e reeditado na língua portuguesa no século XIX. A nota pessoal, de experiência vivida, aproximou-o, de certo modo, da nova sensibilidade que se instalaria com o Romantismo, distanciando-o um tanto da parafernália neoclássica crescentemente insuportável do Arcadismo decadente. Desde a primeira lira de Marília de Dirceu já se sente a supremacia do indivíduo sobre a camisa-de-força do estilo de época, o uso mitigado da máquina mitológica, o frescor das imagens, a inegável qualidade lírica que consegue arejar o improvável locus amenus [sic] do Arcadismo e que, unida ao poder transmutador da realidade histórica de todos conhecida, faz do livro um dos momentos centrais da poesia brasileira".
} 
incontornáveis para os estudos sobre as letras luso-brasileiras. Alcir Pécora $(1995$, p. 2) escreveu um comentário parcialmente elogioso ao estudo em que apresentava ressalvas bem fundamentadas. A seu ver:

Ruedas mostra de modo convincente a filiação das "Liras 11, 53 e 77" da Marília de Dirceu, de Tomás Antônio Gonzaga, ao "Soneto LXI", de Garção, na edição de Azevedo Castro (Roma, 1888). Mas isto não Ihe basta. Quer demonstrar, nas pegadas de Antonio Candido, que as convenções pastoris funcionam apenas "ao nível explícito" e que o modelo da aurea mediocritas, em Gonzaga, é sublimação de uma obsessão pessoal, reposta por exemplo no tema dos bens materiais do pastor. [...] Francamente, este final "mezzo-psicanalítico" parece-me bem desastrado e dá uma orientação duvidosa a todo o estudo. ${ }^{26}$

Três anos depois, Joaci Pereira Furtado 27 (1998, p. 136) preparou uma resenha de maior fôlego, em que destacava algumas imprecisões e equívocos do pesquisador mexicano. Para o crítico, o "empirismo interpretativo decorre da incapacidade de apreender as preceptivas que constituem o discurso literário em seu tempo, além de revelar ausência de autocrítica da historiografia enquanto discurso ela mesma - pois suas categorias são dadas como evidentes e universais". ${ }^{28}$ De fato, Jorge de la Serna propõe uma leitura em que o teor da pesquisa nem sempre conta com o mesmo rigor da análise, o que o leva a formular hipóteses nem sempre consistentes:

Imitando a Arcádia de Roma que havia sido institucionalizada em 1690 para honrar a memória de Cristina da Suécia por ocasião da sua morte e como reação aos excessos do maneirismo italiano, a Arcádia Lusitânia teve também sua sede bucólica, ao menos no nome, que se chamou Monte Mênalo, e aí, imaginariamente, congregavam-se seus membros disfarçados de pastores. Os nomes arcádicos, pseudônimos ao gosto da tradição clássica, cumpriam também uma função

\footnotetext{
${ }^{26}$ Alcir Pécora parece aludir ao que consta da Formação da Literatura Brasileira: "[...] a fixação [de Cláudio] à terra, a celebração dos seus encantos, conduzem ao desejo de exprimi-la no plano da arte" (CANDIDO, 2000, p. 88).

27 No ano anterior, Furtado havia publicado Uma República de Leitores, que se tornou leitura incontornável para se falar melhor sobre Tomás Antônio Gonzaga e, por extensão, do "Arcadismo" lusobrasileiro.

${ }^{28} \mathrm{Em}$ pesquisa recente, Caio César Esteves de Souza observou que "Um trabalho que se propusesse a analisar exaustivamente a existência desse silêncio na base do discurso nacionalista da crítica tradicional encontraria alguns problemas básicos em sua realização. O principal seria a dificuldade (e, no limite, impossibilidade) em mapear todos os discursos dessa vertente crítica para analisar o que silenciam, já que muitos críticos nas últimas décadas se dedicam ao estudo de autores e obras específicos, praticando close readings que buscam, cada vez mais, apagar os pressupostos teóricos de suas análises, como se elas surgissem naturalmente do texto literário e o crítico fosse apenas suficientemente perspicaz para percebê-las daquela maneira" (SOUZA, 2017a, p. 15).
} 
congregadora, pois, ao substituir o nome verdadeiro pelo criptônimo pastoril, aqueles poetas despojavam-se transitoriamente das diferenças de posição social, para confraternizar em um âmbito de fantasia democrática e de aristocracia literária (SERNA, 1995, p. 57).

Bastaria ajustar melhor a lupa para diagnosticar a conformidade daqueles homens letrados, ciosos das etiquetas cortesãs, às várias formas da convenção ${ }^{29}$, como sugere o cenário bucólico ${ }^{30}$, figurado artificialmente em seus versos. Apesar desses índices, leituras de cunho biografista e nativista passaram a deduzir traços de personalismo sincero e pré-ufanismo nacional em estrofes teoricamente inspiradas por Deus, pelos afetos e pela natureza exuberante: rio, pedra, ouro. No Florilégio da Poesia Brasileira, publicado inicialmente em Lisboa, no ano de 1850, Francisco Adolfo de Varnhagen (1946, p. 15) defendia o caráter emancipatório da poesia teológico-nacionalista:

Lancemos as vistas para o nosso Brazil. Deus o fade igualmente bem, para que aqui venham as letras a servir de refugio ao talento, cançado dos esperançosos enganos da política! Deus o fade bem, para que os poetas, em vez de imitarem o que leem, se inspirem da poesia que brota com tanta profusão do seio do proprio paiz, e sejam antes de tudo originaes - americanos.

Houve quem percebesse, nos textos "preambulares" (CARVALHO, 2009) que acompanham os poemas ("Prólogos", "Cartas ao Leitor" e "Notas Históricas"), testemunhos "honestos" dos poetas. Compreendidos como relatos autênticos, assumiriam o estatuto de documento "histórico" e aumentariam a credibilidade subjacente aos versos "nativistas". ${ }^{31}$ Face à sanha por uma concepção sistêmica de

29 “O termo 'idílio' deriva de eidos, que significa uma composição simples, um 'pequeno poema', de 100 a 200 versos. A conotação de 'pastoral' que se ligou ao termo como a qualidade de 'idílico' seria uma construção posterior em função da 'ambientação da serenidade campestre' característica dos poemas chamados 'bucólicos' porque representavam o ideal epicurista, pois o campo era o lugar adequado do culto ao deus Pã" (LIMA, 2008, p. 52).

30 “[...] no final do século XVII e no seguinte, uma verdadeira febre de viajar se apoderou dos europeus. [...] Portugal não fugiu à regra, e mesmo omitindo-se menção da abundantíssima literatura de expansão, da época das descobertas, são de assinalar nesses séculos 'memórias' e 'relações' como as de Pedro Norberto ou Francisco Morais Pereira. Criou-se uma mentalidade colectiva de evasão e de fuga a partir também da leitura, e muitos desejaram ausentar-se das cidades segundo formas permitidas pela bolsa ou pela imaginação mais ou menos rica. De qualquer modo, com sinceridade ou sem ela, o certo é que a vida simples e a fuga dos meios urbanos se impuseram como uma moda" (CRISTÓVÃO, 1981, p. 105).

31 "O prólogo, como parte retoricamente instituída de um livro, deve inserir-se após a dedicatória e regulase segundo princípios determinados pela mesma retórica. Deve dirigir-se, em estilo médio, ao conjunto dos leitores, "dando-lhes razão da obra, do estilo e divisão dela". Diferente deve ser a dedicatória, que, em estilo alto por ser um encômio, se dirige ao mecenas, individualmente, mas compreendido como instituição hierarquicamente superior" (VALLE, 2003, p. 108). De acordo com Djalma Espedito de Lima (2008, pp. 32-33), “[...] é evidente no Prólogo [de Vila Rica] a utilização do topos da humildade, aplicado 
literatura, que atenda aos critérios de um projeto nacional, desprezam-se as letras lusobrasileiras (e os seus estudiosos) e restringe-se o ensino de literatura brasileira a partir do século XIX. Para justificá-lo nada mais conveniente que desprezar o estudo dos gêneros, das formas textuais, das tópicas e dos níveis de expressão.

Por esse motivo, até pouquíssimo tempo quase ninguém ousava dizer que Cláudio, Tomás, Alvarenga, Basílio, Durão etc., lançavam mão de fórmulas de captatio benevolentiae em textos que funcionavam. efetivamente. como Exordium. Esquece-se, providencialmente, que os poetas da segunda metade do Setecentos escreviam ciosos de cumprir normas e respeitar convenções que pouco, ou nada, tinham a ver com o suposto desejo de derrubar a Coroa do alto de um outeiro ou de um casal encravado nas Minas. Como salienta Joaci Pereira Furtado (1997, p. 35), na pesquisa sobre as Cartas Chilenas, atribuídas a Gonzaga:

O próprio fato de haver escolhido a forma de "cartas" confere ao poeta outro importante recurso retórico. Primeiro porque apenas um assunto grave ou suficientemente relevante levaria alguém a escrever tanto para tão longe, como faz supor a lógica da sátira. Segundo, porque o ambiente epistolar permite um tom mais informal e intimista, propício aos arroubos passionais com que Critilo pontua as Cartas Chilenas e procura atrair a antipatia do leitor contra Fanfarrão Minésio e seu governo. Ao mesmo tempo, o poeta abre espaço para o exercício da naturalidade ${ }^{32}$ preconizada pelos cânones poéticos da época.

Exemplos da sobrevalorização do "nacional" sobre o convencional estão nas impressões de José Veríssimo, formuladas em 1916:

\begin{abstract}
Mais numerosa e mais densa que nenhuma outra do Brasil, [n]a população de Minas, aquela ao menos que tinha Vila Rica por centro imediato, sentia-se melhor o contato recíproco, criador da solidariedade. Sendo a mais rica, era também a mais isenta, a mais desvanecida de suas possibilidades. Este desvanecimento bairrista tinha-o Tiradentes em sumo grau. $O$ espírito localista, feição congênita dos mineiros, oriundos das condições físicas e morais do desenvolvimento da capitania, fortificava ali o nativismo ou nacionalismo regional. $O$ sentimento da liberdade e da independência,
\end{abstract}

retoricamente como captação de benevolência de seu leitor. O poeta não ostenta, nem espera ser reconhecido pela elaboração de uma epopeia".

32 Confundido com "espontaneidade", o termo "naturalidade" foi empregado por diversos críticos que não foram capazes (ou não quiseram) ver artifício, ou seja, produção do efeito de naturalidade na poesia setecentista: "[...] a naturalidade parece obtida por recuperação do passado e se exprime pela espontaneidade do sentimento" (CANDIDO, 2000, p. 97 - grifos meus). 
atribuído aos montanheses, parece ter em Minas mais uma vez justificado o conceito. Foi este meio que produziu a floração de poetas que é a plêiade mineira (VERÍSSIMO, 1963, p. 95).

E nos juízos em defesa da antecipação do Romantismo, como pretendia Manuel Bandeira, trinta e um anos depois:

Não há nada na obra desses poetas [mineiros] que a possa extremar do arcadismo português, mas como na poesia de Bocage e de Anastácio da Cunha já se podem distinguir uma ou outra vez uns como prenúncios do romantismo, assim em certos dos nossos árcades é de observar alguma coisa que representava, na emoção mais sincera ou no aproveitamento do elemento brasileiro, uma força renovadora ainda sem consciência de si mesma (BANDEIRA, 2009, pp. 18-20).

Se as sentenças de José Veríssimo e Manuel Bandeira se restringissem aos manuais que escreveram, talvez houvesse possibilidade de os poetas luso-brasileiros serem percebidos de outra forma e, assim, ter seu nome e obra reabilitados. Porém, não foi isso o que aconteceu. Desde meados do século XIX, eles foram sido sistematicamente desvalorizados, como se imitar modelos e aplicar preceptivas vigentes em seu tempo os apequenassem. Paralelamente à perpetuação de certos preconceitos da historiografia, os trabalhos que visavam a relativizar o que dizia incerta crítica - iniciado na década de 1980 - passou a ser combatido com crescente vigor por defensores incondicionais do cânon crítico, erigido em torno de um cânon "literário" cada vez mais restrito, refratário a outros modos de ver poesia e compreender os nexos entre a cultura, a história, a retórica, as leis e os tratados de cortesania. Esse tópico também divide a crítica brasileira. Para André Luís Nepomuceno (2002, p. 85), antes da transferência da Coroa portuguesa para o Rio de Janeiro, em janeiro de 1808, não se poderia falar em "corte" na América Portuguesa:

Se o petrarquismo como fenômeno literário, ao longo de sua trajetória clássica e neoclássica, esteve intimamente ligado ao sistema de valores estabelecido pela sociedade de corte, na América Portuguesa, a importação desses elementos literários contradiz sua própria origem e razão de ser, já que não existiu uma sociedade de corte, ou algo parecido que a substituísse. Essa parece ter sido, inclusive, uma das decepções de Cláudio Manuel da Costa, quando de seu retorno ao Brasil, por volta de 1754 , já que anos depois, por ocasião da publicação de suas Obras em Portugal, teria confirmado no "Prólogo ao Leitor" 
que a volta à colônia (pátria) e à "grossaria" [sic] dos seus gênios" seria uma espécie de sepultamento na ignorância.

Adeptos de uma concepção idealista de "literatura" que remonta aos primórdios do Romantismo, críticos do XIX etiquetaram os homens letrados segundo o paradigma do "Barroco", inventado por Heinrich Wölfflin, como percebeu João Adolfo Hansen (2004, p. 27), em prefácio à segunda edição de A Sátira e o Engenho:

Suprimi redundâncias e também eliminei, sempre que conveniente, a noção de "barroco" como classificação dos estilos dessa poesia. Quando escrevi o texto, em 1987, não pensava nisso, mas hoje sei que "o Barroco" é Wölfflin, ou seja, as categorias dedutivas do idealismo adaptado teleologicamente em programas de invenção de tradições nacionais e nacionalistas, sem maior pertinência ou interesse para dar conta da primeira legibilidade normativa da poesia do século XVII. Nas interpretações brasileiras dela, o interesse heurístico suplanta o histórico.

A condenação moral dos poetas, em que faltaria "originalidade" e sobejaria tara sexual, não se limitou ao Seiscentos. ${ }^{33}$ Esse modo de ver também foi aplicado aos "árcades". Quer dizer, os raros homens letrados de Vila Rica, a flutuar entre a lama e o ouro, estariam a proclamar "verdades" e a externar o que efetivamente "sentiam" em relação às mulheres de papel e ao "seu" país - "terra adorada" a antecipar versos do hino nacional brasileiro. Durante muito tempo, desprezou-se o fato de que eles percorreram, tortos, as ladeiras da "colônia", impulsionados pela cobiça do ouro e a ambição de subir na hierarquia administrativa, com vistas a receberem maior quinhão do poder emanado pela coroa. ${ }^{34}$

\footnotetext{
33 "Apesar de seu ideal de simplicidade e de seu desejo de garantir certa autonomia em relação à vida cortesã, a Arcádia não rompeu com os convencionalismos da cultura barroca, no que se refere tanto às inclinações eruditas, como às práticas laudatórias e de celebração literária dos acontecimentos importantes que alterassem a existência da corte ou a vida dos personagens destacados" (SERNA, 1995, p. 59). Dois anos depois, Edward Lopes seguia em direção parecida: "Parece, pois, que a expressão [poeta] "de transição" seja inservível como categoria crítica. Ocorre, todavia, que não conhecemos nenhuma outra capaz de exprimir com mais justeza uma primeira definição do papel histórico de Cláudio: ele é, de fato, um continuador da época barroca, entre nós, quer dizer, da literatura portuguesa feita no Brasil, e é, ao mesmo tempo, o iniciador do estilo neoclássico na língua portuguesa, tanto quanto o iniciador da "fase brasileira" da literatura nacional" (LOPES, 1997, pp. 65-66).

${ }^{34}$ É o que já se via no Curso de Literatura Portuguesa e Brasileira, publicado por Francisco Sotero dos Reis em 1873. Os "árcades" mineiros, matéria do quarto tomo, eram apresentados como "precursores" da "Literatura Brasileira" (Cf. REIS, 2014, p. 24). A "Lição LXX" se inicia nestes termos: "Tenho, Senhores, de ocupar-me hoje pela primeira vez com um poeta nascido no Brasil, posto pertença ainda ao tempo em que a literatura era comum aos dois povos, brasileiro e português, que formavam então uma só nação.
} 
Há muito se sabe que a poesia produzida durante o Setecentos obedecia a convenções do tempo e a preceitos retórico-poético que remontavam à chamada Antiguidade e ao "Renascimento" europeu. Tampouco se ignora que os homens letrados ocupavam postos estratégicos na administração do reino e que a produção de versos era um dentre os vários critérios para demonstrar engenho, agudeza, prudência e demais virtudes civis $^{35}$, a assegurar a circulação entre os pares e se distinguir perante os súditos provenientes de outros estratos sociais. Como salienta o historiador Marco Antonio Silveira (1997, p. 46-47):

\begin{abstract}
Apesar das variadas classes sociais existentes no interior do Império lusitano, o que definia primordialmente a participação no grupo dirigente era o prestígio; daí o fato de a sociedade portuguesa apresentar uma estratificação estamental. Tal prestígio, capaz de conferir "nobreza" aos membros do estamento, cada vez menos, durante a época moderna, constituía privilégio exclusivo das antigas famílias proprietárias de terra. Pelo contrário: à proporção que as conquistas no Ultramar avançavam e tornava-se mais evidente que a economia lusa era eminentemente mercantil, os títulos honoríficos e a incrustação na máquina administrativa afirmavam-se como meios de distinção. Ambos os caminhos, afinal aproximavam do rei. De outro lado, todo o aparato estético, valorativo e comportamental relativo à honra apresentava-se como indispensável na definição do lugar de cada um na sociedade.
\end{abstract}

Em pesquisa sobre a representação do gosto na cultura, entre os séculos $\mathrm{XVI}$ e XVIII, Ana Hontanilha (2010, p. 30) articula o cultivo do bom gosto à noção de coletividade:

\begin{abstract}
O bom gosto é o juízo que distancia o indivíduo da urgência de suas necessidades e paixões. A moderação das exigências pessoais não é um exercício ascético para a purificação da alma. A contenção do desejo obedece a considerações que dão prioridade ao bem comum sobre o pessoal. O exercício desta reiterada renúncia em que consiste o bom gosto permite ao indivíduo adquirir um maior grau de liberdade e independência a respeito dos avatares da vida.
\end{abstract}

\footnotetext{
Este poeta, que foi contemporâneo de Garção e Dinis, pois que floresceu nos reinados de D. José I e Maria I, é frei José de S. Rita Durão, autor do poema épico Caramuru" (Idem, ibidem, p. 77).

35 "A civilidade é composta de conveniência (bonne sceance, bonne grace) e afabilidade. A primeira se requer nas palavras (claras, comuns, inteligíveis), nas ações e feições (comedidas e tranquilas) e nas vestimentas (sem supérfluos, ao modo corrente). A segunda compreende bem receber as pessoas, respeitar, ter feição agradável, escutar com paciência, misturar doçura e severidade; também participam aqui as agudezas e os gracejos, a serem usadas moderadamente e sem incorrer na bufonaria; parte da afabilidade está nos cumprimentos, que devem se pautar pelo saber ser grato e pela discrição, esta julgada rara nas cortes" (MíssıO, 2012, p. 107).
} 
É curioso que esses dados continuem a ser negligenciados por uma parcela considerável de nossos historiadores e "críticos de literatura". O exame dos versos produzidos durante os séculos XVII e XVIII permitiria atestar a obediência dos poetas às convenções vigentes em seu tempo. Em lugar de "renovarem" as letras "nacionais", como defendem alguns, os poetas luso-brasileiros estavam a praticar a emulatio, também como forma de filiar à auctoritas que remonta(va) a Homero, passava por Teócrito, Virgílio, Horácio, Dante, Petrarca, Camões etc.

\section{Refutação}

Seria quase um truísmo afirmar que cada poeta se apropriava dos códigos e reproduzia modelos em acordo com os recursos que tivessem à disposição. Isso não precisaria ser reiterado em um livro que buscasse conciliar a "tradição" e a superação de certos modelos. Poder-se-ia dizer que Ruedas de la Serna $(1995$, p. 80) resvala no senso comum, na tentativa de defender o ponto de vista que tomou emprestado de seu mestre:

[...] o texto contém, implicitamente, pela natureza do gênero ao qual pertence, elementos "extratextuais" inseparáveis dele, sem os quais é impossível abarcá-lo na totalidade que é factível alcançar. Tanto que esse poema em particular não seria o mesmo, ainda com a mesma estrutura inalterada, se fosse obra de outro poeta. Se isso é verdade, como nós pensamos - e Antonio Candido refere-se especificamente à poesia arcádica -, deveremos aceitar, em princípio, que o arcadismo brasileiro não teve a mesma significação que o português, por mais que se tratasse do mesmo 'código literário', da mesma convenção, dos mesmos nomes de pastores e da mesma tradição que nutre ambas as Arcádias (grifos meus).

O fato é que continua a haver quem psicologize os poetas, transformando-os em personagens "sensíveis" e "autênticas" 36 em lugar de avaliar a performance de sua persona poética, como se o estudo das letras luso-brasileiras pudessem ou devessem se limitar à "descoberta" do segredo "autoral", instância confundida com a de "indivíduo" - conceito que não existia no Estado do Brasil, pelo menos até meados do Oitocentos, quando as noções de império cederam lugar ao discurso dito "republicano".

\footnotetext{
36 “[Em Cláudio], a emoção poética possuía raízes autênticas, ao contrário do que dizem os críticos, inclinados a considerá-lo mero artífice" (CANDIDO, 2000, p. 85).
} 
Isso explicaria que um poeta com o Cláudio Manuel da Costa padecesse com a obsessão pela pedra, o que seria ilustrado pela saudade que sentiria do Brasil; que o ouvidor de Vila Rica, Tomás Antônio Gonzaga, tivesse ideia fixa pelos rios pátrios; que Alvarenga Peixoto, e também Silva Alvarenga, também descrevessem as várias formas da pedra (penha, penedo, penhasco) como índice de sentimentalismo e desejo de pertencer à "terra", muito antes de isso ser cogitado ou autorizado pela Coroa.

Em que pese a melhor intenção dos críticos que atribuem "originalidade", "civismo" e "santidade" onde não as havia, não se pode esquecer que o elemento "pedra" integrava o repertório de lugares-comuns da poesia que se produzia durante aquele período, não só no Estado do Brasil, mas também em Lisboa - como sugerem os versos legados pelos versejadores que viviam por lá. Como não se limitavam ao horizonte rochoso com que Cláudio Manuel da Costa lidava, a pedra, a penha ${ }^{37}$ e seus derivados comparecem, em sentido denotativo ou metafórico, aos versos que abrem as Obras Poéticas de Correia Garção $(1825$, p. 3):

Se o peito não tiver de rocha dura, Fuja de ouvir cantar tamanho dano, Que a desabrida voz do desengano O mais firme semblante desfigura.

Em outras produções, a penha se combina às emoções do eu lírico, como mostra este poema de Bocage $(1875$, p. 106):
Absorto, convulso, e frio, Deixo de erriçada grenha A Fúria em côncava penha, Seu lar medonho, e sombrio: Debalde luto, e porfio Contra a Sorte desde então; Céus! Não achar compaixão! Céus! Amar sem ser amado! Bárbara lei do meu fado!

Esta penha pode ser contagiada figurativamente por incerta figura feminina, de que fala o eu poético inventado por Domingos dos Reis Quita (1766, p. 48):

Por verem de teus olhos

\footnotetext{
${ }^{37}$ Por sinal, a imagem da pedra teria origem em outros tempos: “[...] sabemos que o rochedo e a caverna fascinaram o culteranismo" (CANDIDO, 2000, p. 92).
} 
Os claros resplendores

Habitam nesta selva

As graças, e os amores.

Por ti penhas, e troncos

Respirando alegria

Cantam sonoros versos

Neste ditoso dia.

Esta outra traduziria a potência dos fenômenos naturais, como acontecia nestes versos de Filinto Elísio (1801, p. 53):

Ronquem roucos trovões, rasquem-se os ares, rebente o mar em vão n'ocos rochedos, solte-se o céu em grossas lanças de água.

Também a rocha serviria como amparo físico e emocional ao pastor que padece de amor, como sugere o soneto de José Anastácio da Cunha (Apud LAPA, 1967, p. 94):

Alta rocha, sustém-me, que esmoreço! De amor não sei se estou para expirar... Como me anseia!... Enquanto não faleço, com a noite quero aqui desabafar.

A seu turno, os penhascos auxiliariam a compor o estado de alma em que se encontra a persona poética, como sugere este soneto do Abade de Jazente (1983, p. 139):

Brutos penhascos, rústicas montanhas, Medonhos bosques, hórrida maleza, Que me vedes, coberto de tristeza, Saudoso habitador destas campanhas.

Como assegurar que o emprego de certos elementos da natureza em versos "árcades" fosse índice de obsessão ou de compensação psicológica pela suposta falta de firmeza de um poeta? Será razoável supor desejo de "fixidez" ou enxergar carência de "identidade nacional" no homem letrado (que não se confundia com as personae que figura em seus versos)?

Estamos no domínio da convenção. E ela não estava solta no tempo, na circunstância e no espaço; mas atrelada a um modo de ver pautado pelo universo cifrado pelas leis, pelos códigos de conduta, na carreira pela distinção social. O cultivo das letras, naquele mundo codificado, não se relacionava com a suposta "genialidade" do homem 
letrado, como se passou a cogitar no século XIX. A escrita, preceito, constituía código de que o poeta engenhoso poderia se valer, a circular entre pares e poderosos da corte. Como salienta Alcir Pécora (2001, p. 193):

Convenhamos, então, que nada pode fazer menos bem à leitura de Silva Alvarenga do que buscar o seu realismo inverossímil: são mais de uma centena de poemas habitados por indefectíveis deuses e heróis olímpicos; musas peripatéticas na companhia de amorezinhos alados e faunos espreitadores; hamadríades animais e florais; zéfiros ligeiros e desejos voadores; pastores cultos, cruas pastoras; montes, prados e ribeiros, batidos sempre pelo soberano e surdo Fado - tudo descrito e retocado sob muita cópia de Virgílio, Horácio, Ovídio e Anacreonte.

Não foram poucos os episódios daqueles que recorreram aos versos para obter o favor, quando não a proteção do reino. Onde estariam as raízes dessa prática? Um dos empregos dessa forma mentis concebida pelos poetas "árcades" guardaria relação com a cultura dos salões e agremiações "literárias", frequentados desde o século XVII na França e em outros reinos da Europa. Hontanilla (2010, p. 43) lembra que:

Com a aparição da figura do honnête homme, o espírito aristocrático começou a sofrer uma série de transformações. Progressivamente, a ideia de nobreza foi relegando a tradição militar a um segundo plano para decantar-se em favor do impulso literário; e o status social passou a expressar, em medida cada vez maior, pelo conhecimento e exercício da atividade poética, uma vez que contribuiu a reduzir um tipo de valoração exclusivamente adstrito às empresas de corte militar. A literatura surge como manifestação da arte de conversar e extensão das atividades de uma sociedade que enfatiza o refinamento e a cultura [...] [Nos] círculos urbanos de comunicação literária, o autor e sua audiência compartilham os mesmos códigos retóricos, as regras morais e os valores sociais.

Relembre-se a trajetória de Basílio da Gama, que, de prisioneiro passou a secretário do Marquês de Pombal, em retribuição aos versos encomiásticos que fez para o estadista e os seus familiares (TEIXEIRA, 1999; 2003). Se é para descobrir motivações "pessoais" dos homens letrados, num tempo de plena sujeição à igreja, ao rei, à lei e aos rapapés da corte, haveria que se perguntar por que a pedra, a rocha e o penhasco não se restringiram aos versos dos "árcades", dentro e fora das partes do Brasil. Esses e outros elementos constavam do "barroco" Botelho de Oliveira e continuaram a ser evocados pelos "românticos" cooptados pelo programa nacionalista. 
Graças àquele punhado de jovens entediados a flanar em Paris, a "penha" também ornamentou o cenário em que o índio figuraria como alegoria emplumada. Ora ele foi representado como "herói" aculturado (DAHER, 2012; COELHO, 2016), talvez em condição menos péssima que a dos escravos negros aportados de várias tribos na África; ora como símbolo "nativista", a tingir de exotismo o discurso do trono. Em todos os casos, sob a falsa guarda do reino e do império, mas quase sempre sob o beneplácito da igreja. 


\section{Referências}

ALBERTI, Leon Battista. Da Arte de Construir: tratado de Arquitetura e Urbanismo. Trad. Sergio Romanelli. São Paulo: Hedra, 2012.

ALORNA, Marquesa de. Obras Poéticas, Tomo II. Lisboa: Imprensa Nacional, 1844.

ANDERSON, Perry. Linhagens do Estado Absolutista. Trad. Renato Prelorentzou. São Paulo: Editora Unesp, 2016.

ARAÚJO, Valdei Lopes de. A experiência do tempo: conceitos e narrativas na formação nacional brasileira (1813-1845). São Paulo: Hucitec, 2008.

ATALLAH, Cláudia C. Azeredo. Da justiça em nome d'El Rey: justiça, ouvidores e Inconfidência no centro-sul da América Portuguesa. Rio de Janeiro: EdUERJ, 2016.

BANDEIRA, Manuel. Apresentação da Poesia Brasileira: seguida de uma antologia. São Paulo: Cosac Naify, 2009.

BASTOS, Rodrigo. A maravilhosa fábrica de virtudes: o decoro na Arquitetura religiosa de Vila Rica, Minas Gerais (1711-1822). São Paulo: Edusp, 2013.

BAXANDALL, Michael. Giotto e os oradores: as observações dos humanistas italianos sobre pintura e a descoberta da composição pictórica (1350-1450). Trad. Fábio Larsson. São Paulo: Edusp, 2018.

BOSI, Alfredo. História concisa da Literatura Brasileira. 39a ed. São Paulo: Cultrix, 2002.

BUENO, Alexei. Uma História da Poesia Brasileira. Rio de Janeiro: G. Ermakoff, 2007.

BOCAGE, Manuel Maria Barbosa du. Obras Poéticas. Vol. III. Porto: Imprensa Portuguesa, 1875.

BORREGO, Maria Aparecida de Menezes. Códigos e práticas: o processo de constituição urbana em Vila Rica colonial (1702-1748). São Paulo: Annablume, 2004.

BOXER, Charles R. A Idade de Ouro do Brasil. Trad. Nair de Lacerda. São Paulo: Companhia Editora Nacional, 1963.

BURKE, Peter. A fabricação do rei: a construção da imagem pública de Luís XIV. Trad. Maria Luiza X. De A. Borges. Rio de Janeiro: Zahar, 1994.

CANDIDO, Antonio. "No limiar do novo estilo: Cláudio Manuel da Costa". In:

Formação da Literatura Brasileira: momentos decisivos. 6a ed. Belo Horizonte: Itatiaia, 2000, pp. 84-102. 
. "Uma Aldeia Falsa". In: . Na Sala de Aula: caderno de análise literária. 4a ed. São Paulo: Ática, 1993, pp. 20-37.

CARVALHO, Maria do Socorro Fernandes de. Poesia de Agudeza em Portugal. São Paulo: Humanitas; Edusp, 2007.

- Preambulares do Livro Seiscentista em Portugal e no Brasil. Piauí: Editora Universitária da UFPI/FAPEPI, 2009.

CASTELLO, José Aderaldo. O Movimento Academicista no Brasil: 1640-1820/22. São Paulo: Conselho Estadual de Cultura, 1969 [Volume I, Tomos 1 a 5].

CASTRO, Aníbal Pinto de. Retórica e teorização literária em Portugal: do Humanismo ao Neoclassicismo. 2a ed. Lisboa: INCM, 2008.

CHAUVIN, Jean Pierre. "O Léxico Real”. Revista do GEL (USP), v. 15, n. 2, São Paulo, 2018, pp. 33-49.

. "Pictórico, categoria do Seiscentos?" Revista Teresa (USP), n. 18, São Paulo, 2018 [2016], pp. 133-149.

COELHO, Mauro Cezar. Do Sertão para o Mar: um estudo sobre a experiência portuguesa na América: o caso do Diretório dos Índios (1750-1798). São Paulo Editora LF, 2016.

CORREIA GARÇÃO, Pedro Antonio. Obras Poéticas. Lisboa: Impressão Régia, 1825.

COSTA, Ana Paula Pereira. Corpos de ordenanças e chefias militares em Minas colonial: Vila Rica (1735-1777). Rio de Janeiro: FGV Editora, 2014.

COSTIGAN, Lúcia Helena (org.). Diálogos da conversão. Campinas: Editora da Unicamp, 2005.

CRISTÓVÃO, Fernando. "Marília de Dirceu" de Tomás Antônio Gonzaga ou A poesia como imitação e pintura. Lisboa: INCM, 1981.

DAHER, Andrea (org.). Oral por escrito: a oralidade na ordem da escrita, da retórica à literatura. Chapecó: Argos; Florianópolis: Editora UFSC, 2018.

A oralidade perdida: ensaios de história das práticas letradas. Rio de Janeiro: Civilização Brasileira, 2012.

ELIAS, Norbert. A Sociedade de Corte: investigação sobre a sociologia da realeza e da aristocracia de corte. Trad. Pedro Süssekind. Rio de Janeiro: Zahar, 2001.

O Processo Civilizador. Volume 1: Uma história dos costumes. 2a ed. Trad. Ruy Jungmann. Rio de Janeiro: Zahar, 2011. 
ELÍSIO, Filinto. Versos. Tomo II. Paris: s/e, 1801.

FERNANDES, Neusa. A Inquisição em Minas Gerais no século XVIII. 3aㅡ ed. Rio de Janeiro: Mauad, 2014.

FURTADO, Joaci Pereira. Uma república de leitores: história e memória na recepção das Cartas Chilenas (1845 - 1989). São Paulo: Hucitec, 1997.

. "Licença para fingir: motes para um debate". Revista do Centro de Estudos Portugueses, n. 1, São Paulo, 1998 pp. 135-140.

GAMA, Luciana. "A retórica do sublime no Caramuru: Poema Épico do Descobrimento da Bahia". Revista USP, n. 57, São Paulo, 2003, pp. 122-137.

GERVINUS, Georg Gottfried. Fundamentos da Teoria da História. Trad. Sara Baldus; Julio Bentivoglio. Petrópolis: Vozes, 2010.

GONÇALVES DE MAGALHÃES, Domingos José. Suspiros Poéticos e Saudades. 5a ed. Brasília: Editora UnB; INL, 1986.

GRAMMONT, Guiomar de. Aleijadinho e o aeroplano: o paraíso barroco e a construção do herói colonial. Rio de Janeiro: Civilização Brasileira, 2008.

HANSEN, João Adolfo. "Retórica e actio nos discursos coloniais". In: DAHER, Andrea (org.). Oral por escrito: a oralidade na ordem da escrita, da retórica à literatura. Chapecó: Argos; Florianópolis: Editora da UFSC, 2018, pp. 61-85.

; MOREIRA, Marcello. Para que todos entendais: poesia atribuída a Gregório de Matos e Guerra: letrados, manuscritura, retórica, autoria, obra e público na Bahia dos séculos XVII e XVIII. Belo Horizonte: Autêntica Editora, 2013.

A Sátira e o Engenho: Gregório de Matos e a Bahia do Século XVII. 2ª ed. Cotia: Ateliê; Campinas: Editora Unicamp, 2004. $10-67$.

"Barroco, neobarroco e outras ruínas". Revista Teresa, São Paulo, n. 2, 2001, pp.

. "As liras de Gonzaga: entre retórica e valor de troca". Revista Via Atlântica, n. 1, São Paulo, 1997a, pp. 40-53.

" "Ut pictura poesis e verossimilhança na doutrina do conceito no século XVII colonial". Revista de Crítica Literária Latino-americana, Lima-Berkeley, v. 45, 1997b, pp. 177-191.

" "Autor". In: JOBIM, José Luís. Palavras da Crítica: tendências e conceitos no estudo da literatura. Rio de Janeiro: Imago, 1992, pp. 11-43. 
HASKELL, Francis. Mecenas e Pintores: arte e sociedade na Itália barroca. Trad. Luiz Roberto Mendes Gonçalves. São Paulo: Edusp, 1997.

HASEGAWA, Alexandre Pinheiro. Os limites do gênero bucólico em Vergílio. São Paulo: Humanitas, 2011.

HESPANHA, António Manuel. Caleidoscópio do Antigo Regime. São Paulo: Alameda, 2012. 2006.

O Direito dos letrados no Império português. Florianópolis: Fundação Boiteux,

JAZENTE, Abade de. Poesias. Lisboa: Editorial Comunicação, 1983 [org. por Miguel Tamen].

KANTOROWICZ, Ernst. The King's two bodies: A study in Mediaeval Political Theology. Princeton: Princeton University Press, 1997.

KOSELLECK, Reinhart. Futuro Passado: contribuição à semântica dos tempos históricos. 3a reimp. Trad. Wilma Patrícia Maas; Carlos Almeida Pereira. Rio de Janeiro: Contraponto; Editora Puc-Rio, 2012.

LAPA, Manuel Rodrigues. Poetas do Século XVIII. 3ạ ed. Lisboa: Seara, 1967.

LARA, Silvia Hunold. "Introdução". In: Ordenações Filipinas: Livro V. São Paulo: Companhia das Letras, 1999, pp. 19-48.

LIMA, Djalma Espedito de. A épica de Cláudio Manuel da Costa: uma leitura do poema Vila Rica. São Paulo: Linear B, 2008.

LOPES, Edward. Metamorfoses: a poesia de Cláudio Manuel da Costa. São Paulo: Editora Unesp, 1997a.

LOPES, Hélio. Letras de Minas e outros ensaios. São Paulo: Edusp, 1997b [Organização de Alfredo Bosi].

MAGALHÃES, Joaquim Romero. Concelhos e organização municipal na época moderna. Coimbra: Imprensa da Universidade de Coimba, 2011.

MARNOTO, Rita. A Arcadia de Sannazaro e o Bucolismo. Coimbra: Imprensa de Coimbra/Faculdade de Letras, 1996.

MAXWELL, Kenneth. A Devassa da Devassa: A Inconfidência Mineira, Brasil e Portugal, 1750-1808. 5a ed. Trad. João Maia. São Paulo: Paz e Terra, 2001.

MELLO, Evaldo Cabral de. Um imenso Portugal: História e historiografia. São Paulo: Editora 34, 2002. 
MíssıO, Edmir. A civilidade e as artes de fingir: a partir do conceito de Dissimulação Honesta de Torquato Accetto. São Paulo: Edusp, 2012.

MONTEIRO, Rodrigo Bentes et al. Raízes do Privilégio: mobilidade social no mundo ibérico no Antigo Regime. Rio de Janeiro: Civilização Brasileira, 2011.

MORATO, Fernando. "Introdução". In: SILVA ALVARENGA, Manuel Inácio da. Obras poéticas. São Paulo: Martins Fontes, 2005. pp. XVII-LIV.

MORELLET et al. A Arte de Conversar. São Paulo: Martins Fontes, 2001 [Organização de Alcir Pécora].

MOTA, Carlos Guilherme. A ideia de revolução no Brasil e outras ideias. São Paulo: Gobo, 2008.

MUHANA, Adma. Poesia e Pintura ou Pintura e Poesia - Tratado seiscentista de Manuel Pires de Almeida. São Paulo: Edusp, 2002. 1997.

A epopeia em prosa seiscentista: uma definição de gênero. São Paulo: Unesp,

NEPOMUCENO, Luís André. A musa desnuda e o poeta tímido: o petrarquismo na arcádia brasileira. São Paulo: Annablume; Patos de Minas: Unipam, 2002.

NOGUEIRA, Érico. Verdade, contenda e poesia nos Idílios de Teócrito. São Paulo: Humanitas, 2012.

OLIVEIRA, Almir de. Gonzaga e a Inconfidência Mineira. Belo Horizonte: Itatiaia; São Paulo: Edusp, 1985.

OLIVEIRA, Manuel Botelho de. Música do Parnaso. Cotia: Ateliê, 2005 [Edição fac-similar organizada por Ivan Teixeira].

PÉCORA, Alcir. Máquina de Gêneros. São Paulo: Edusp, 2001.

"A fortuna crítica da Arcádia". Jornal de Resenhas, 8.11.1995, 3p - Disponível em: http://jornalderesenhas.com.br/resenha/a-fortuna-critica-da-arcadia/ - Acesso em 4.2.2019.

- Teatro do Sacramento: a unidade teológico-retórico-política dos sermões de Antônio Vieira. Campinas: Editora da Unicamp; São Paulo: Edusp, 1994.

PIERANGELLI, José Henrique. Códigos Penais do Brasil: evolução histórica. Bauru: Jalovi, 1980.

PINHO, Ruy Rebello. História do Direito Penal Brasileiro: Período Colonial. São Paulo: Bushatsky; Edusp, 1973. 
PUNTONI, Pedro. O Estado do Brasil: poder e política na Bahia colonial - 1548-1700. São Paulo: Alameda, 2013.

QUITA, Domingos dos Reis. Obras Poéticas. Tomo I. Lisboa: Oficina de Miguel Manescal da Costa, 1766.

REIS, Francisco Sotero. Curso de Literatura Portuguesa e Brasileira: fundamentos teóricos e autores brasileiros. Rio de Janeiro: Editora Caetés, 2014.

REVEL, Jacques. "Os usos da civilidade". In: CHARTIER, Roger (org.). História da Vida Privada 3: da Renascença ao Século das Luzes. Trad. Hildegard Feist. São Paulo: Companhia das Letras, 2013, pp. 169-210.

RICUPERO, Rodrigo. A formação da elite colonial: Brasil c. 1530-1630. São Paulo: Alameda, 2009.

RODRIGUES, Aldair Carlos. Limpos de sangue: familiares do Santo Ofício, Inquisição e sociedade em Minas colonial. São Paulo: Alameda, 2011.

RODRIGUES, André Figueiredo. O Clero e a Conjuração Mineira. São Paulo: Humanitas, 2002.

RODRIGUES, José Wasth. Documentário arquitetônico relativo à antiga construção civil no Brasil. 2a ed. São Paulo: Edusp, 1975.

RÜSEN, Jörn. História Viva - Teoria da História III: formas e funções do conhecimento histórico. Trad. Estevão de Rezende Martins. Brasília: Editora UnB, 2010.

SALGADO, Graça (coord.). Fiscais e meirinhos: a administração no Brasil colonial. 2ª ed. Rio de Janeiro: Nova Fronteira, 1985.

SCHWARTZ, Stuart B. Burocracia e sociedade no Brasil colonial: o Tribunal Superior da Bahia e seus desembargadores, 1609-1751. Trad. Berilo Vargas. São Paulo: Companhia das Letras, 2011.

SERNA, Jorge Antonio Ruedas de la. Arcádia: tradição e mudança. São Paulo: Edusp, 1995.

"Prólogo". In: GONZAGA, Tomás Antonio. Marilia de Dirceo. São Paulo: Edusp; México: Fondo de Cultura Económica, 2002, pp. 15-37.

SILVA, Rogério Forastieri da. Colônia e Nativismo: a História como "Biografia da Nação". São Paulo: Hucitec, 1997.

SILVEIRA, Marco Antonio. O universo do indistinto: Estado e sociedade nas Minas setecentistas (1735-1808). São Paulo: Hucitec, 1997. 
SILVEIRA, Pedro Telles da. O cego e o coxo: historiografia, erudição e retórica no Brasil do século XVIII. São Paulo: Fap-Unifesp, 2016.

SOUZA, Caio César Esteves de. Alvarenga Peixoto $e(m)$ seu tempo. Dissertação de Mestrado. São Paulo: FFLCH/USP, 2017a.

SOUZA, Laura de Mello e. Desclassificados do ouro: a pobreza mineira no século XVIII. Rio de Janeiro: Ouro Sobre Azul, 2017b.

SOUZA, Maria Eliza de Campos. Ouvidores de Comarcas de Minas no século XVIII. São Paulo: Alameda, 2016.

SUMPF, Roberta Giannublio. Os cavaleiros do ouro e outras trajetórias nobilitantes nas Minas setecentistas. Belo Horizonte: Fino Traço, 2014.

TEIXEIRA, Ivan (org.). Épicos. São Paulo: Edusp; Imprensa Oficial, 2008. . "Hermenêutica, retórica e poética nas letras da América Portuguesa". Revista USP, n. 57, São Paulo, 2003, pp. 138-159. Mecenato Pombalino e Poesia Neoclássica. São Paulo: Edusp, 1999.

TOCQUEVILLE, Alexis de. O Antigo Regime e a Revolução. Trad. Rosemary Costhek Abílio. São Paulo: Martins Fontes, 2017.

VALLE, Ricardo Martins. "A construção da posteridade ou A gênese como ruína (Um ensaio sobre Cláudio Manuel da Costa)". Revista USP, n. 57, São Paulo, 2003, pp. 104121.

VARNHAGEN, Francisco Adolfo de. Florilégio da Poesia Brazileira ou collecção das mais notáveis composições dos poetas brasileiros falecidos, contendo as biografias de muitos deles, tudo precedido de um Ensaio Historico Sôbre as Lettras no Brazil. Tomo I. Rio de Janeiro: Academia Brasileira de Letras, 1946.

VERÍSSIMO, José. História da Literatura Brasileira: de Bento Teixeira (1601) a Machado de Assis (1908). 4a ed. Brasília: Editora da UnB, 1963.

VIANA, Fábio Henrique. A paisagem sonora de Vila Rica e a música barroca das Minas Gerais (1711-1822). Belo Horizonte: C/Arte, 2012.

VITRÚVIO. Da Arquitetura. Trad. Marco Aurélio Lagonegro. São Paulo: Hucitec; Fundação Para a Pesquisa Ambiental, 1999. 


\section{Poética, Retórica \& Cortesia}

ACCETTO, Torquato. Da dissimulação honesta. Trad. Edmir Míssio. São Paulo: Martins Fontes, 2001.

ARISTÓTELES. Poética. Trad. Paulo Pinheiro. São Paulo: Editora 34, 2015.

Retórica. Trad. Manuel Alexandre Júnior; Paulo Farmhouse Alberto; Abel do Nascimento Pena. São Paulo: Martins Fontes, 2012.

BOILEAU. L'Art Poétique. Paris: Hachette, 1946.

GRACIÁN, Baltasar. Arte de Ingenio, Tratado de la Agudeza. 2ª ed. Madri: Cátedra, 2010.

LULIO, Antonio. Sobre el Decoro de la Poética. Trad. Antonio Sancho Royo. Madrid: Ediciones Clásicas, 1994.

OLIVEIRA, Custódio José de. Tratado do Sublime de Dionísio Longino. Lisboa: INCN, 1984.

QUINTILIANO. Instituição Oratória. Trad. Bruno Fregni Bassetto. Campinas: Editora Unicamp, 2015-2016 [4 Tomos].

TRINGALI, Dante. A Arte Poética de Horácio. São Paulo: Musa Editora, 1993. 


\section{II - Estudos \\ (Séculos XVII, XVIII e XIX)}




\title{
Revisão de Bento Teixeira
}

\author{
[...] é excelente e evita a vulgaridade aquela [elocução] que usa \\ palavras estranhas. Por estranha entendo a palavra rara, a metáfora, a \\ palavra alongada e tudo que for contra o que é corrente (Aristóteles). ${ }^{38}$ \\ Deus o fade bem para que os poetas, em vez de \\ imitarem o que leem, se inspirem da poesia que brota \\ com tanta profusão do seio do próprio país, e sejam \\ antes de tudo originais - americanos \\ (Francisco Adolfo de Varnhagen). ${ }^{39}$
}

Resumo: $O$ artigo propõe-se a rever os estudos em torno do poeta luso-brasileiro Bento Teixeira (1561-1600), cuja obra maior, Prosopopeia, continua sendo mais referenciada do que efetivamente lida; mais depreciada que compreendida. A partir da década de 1980, houve grande reviravolta nas pesquisas a seu respeito, o que sugere reposicionar autor e obra no estreito cânon sedimentado pela crítica nacional.

Palavras-Chave: Bento Teixeira; Proposopeia; Fortuna crítica.

Abstract: In this article we intend to review the studies about the Portuguese-Brazilian poet Bento Teixeira (1561-1600), whose major work, Prosopopeia, has been considered more as referenced than a efective reading; more a depreciated work than understood. Since the 1980s, there has been a reorientation of research concernig it, which suggests the repositioning of the author and his work in the narrow canon sedimented by the brazilian criticism.

Keywords: Bento Teixeira; Prosopopeia; Critical fortune.

\section{Arremedo}

Durante muito tempo, discorrer sobre o letrado Bento Teixeira (1561-1600) incorreu em eventual risco. Primeiramente, porque era considerado autor de um poema menor, espécie de arremedo camoniano ${ }^{40}$. Praticamente ignorado pela crítica portuguesa, e espinafrado pela crítica brasileira, Prosopopeia foi convertido de obra (a ser lida) a baliza temporal imprecisa: o início do "Barroco" nas bandas de cá. Sabe-se que Prosopopeia é pouco citado; calcula-se que seja raramente lido e (quase) nunca apreciado com maior objetividade e menor anacronismo. Julgada como se se tratasse de obra curta, defeituosa e de qualidade inferior (pretensioso arremedo de Camões), a

\footnotetext{
${ }^{38}$ Poética, 2008, p. 22.

${ }^{39}$ Florilégio da Poesia Brasileira, 1950, p. 15.

${ }^{40}$ Cf. Antônio Soares Amora. A Prosopopeia de Bento Teixeira, 1957.
} 
revelar intenções "ideológicas" em prol do governador de Pernambuco ${ }^{41}$, o leitor substitui o contato com o texto pela opinião tomada de empréstimo a críticos terceiros que, nem por isso, dedicaram maior atenção às seções do poema, ao teor dos seus versos, tampouco aos procedimentos mobilizados pelo poeta.

O segundo motivo, alegado por outra parcela da crítica, ultrapassa (ou negligencia) o dado estético. Bento Teixeira era filho de judeus ${ }^{42}$ portugueses, fugidos das malhas e martírios prometidos pelo Tribunal do Santo Ofício. Como se sabe, desde a instalação administrativa da Santa Inquisição ${ }^{43}$ em Portugal, em $1536^{44}$, as famílias de origem semita lidaram com os caprichos do Trono e do Vaticano. Na síntese de Jairo Luna:

Sofrendo a família perseguições por parte da Santa Inquisição por motivo de prática de judaísmo, ao Brasil chegaram em 1567, sendo o menino Bento ainda muito criança. Era filho de Manuel Álvares de Barros, cristão-novo e Lianor Rodrigues, cristã-nova. Depois de passarem pelo Espírito Santo e Rio de Janeiro, veio a perder os pais na Bahia, por volta de 1759. Casou-se com Filipa Raposa, cristã velha em 1583, e em 1584 estabeleceu-se como professor de retórica em Olinda. Em 1588, por motivos financeiros, transfere-se para Iguaraçu. A esposa começou a traí-lo e acusava-o de "mau cristão e judeu". Sendo acusado de blasfêmia, foi a auto-de-fé em 31/07/1589, conseguindo a absolvição. Voltou para Olinda. Em 1594 matou a esposa devido a adultério e sendo também levado a processo por judaísmo. Em 1599, confessou e abjurou o judaísmo,

41 Para José Aderaldo Castello, Prosopopeia resultaria de "demonstração evidente de bajulação e servilismo" (CASTELO Apud PEREIRA, 1997, p. 10).

42 "A primeira referência a Bento Teixeira encontra-se nas Denunciações da Bahia. Em 18 de agosto foi denunciado pelo Padre Antônio da Rocha por ter afirmado, citando argumento de outrem, e num escrito dirigido aos padres da Companhia de Jesus, que 'se Deus tinha ordenado a uma pessoa ir ao Inferno ou ao Paraíso, que, por mais que aquela pessoa fizesse de bem, não havia de deixar de ir ao Inferno e, por mais que fizesse de mal, não havia de deixar de ir ao Paraíso, pois por Deus assim estava ordenado'." (LIPINER, 1969, p. 205). De acordo com Gonsalves de Mello: "O Padre Manuel do Couto (23.IX.1595) confirmou que Bento Teixeira fora 'seu condiscípulo na Bahia, nas escolas da Companhia, ano e meio no Latim e alguns dois anos nas Artes e que nesse tempo ouviu que ele era bom estudante e que nesse tempo viu que procedia ele como bom cristão no exterior'." (MELLO, 1986, p. 29).

43 "A imagem da ação arbitrária é complementada pela imagem da ação interessada. Com efeito, as penas para o crime da heresia compreendiam não apenas a excomunhão e a entrega do condenado ao braço secular para sua execução, mas também o confisco de todos os seus bens. Esse último aspecto é aquele a que as petições dos cristãos-novos mais frequentemente fazem alusão, pois significa a ruína de toda a família, sem falar na inabilitação dos descendentes do condenado para o exercício de diversos cargos e profissões" (BETHENCOURT, 2000, p. 340).

44 “Em 1536, sob o reinado de Dom João III, O Piedoso, é instalado [por exigências econômicas e políticas (e não religiosas)] o Tribunal da Inquisição em Portugal. Este fato, pelo menos até 1593, nenhuma repercussão teve no Brasil, pelo menos em Pernambuco" (VILAR, 1995, p. 30). De acordo com Francisco Bethencourt, "A bula de estabelecimento do tribunal Cum ad nihil magis, assinada pelo papa em 23 de maio de 1536, nomeava três bispos (de Ceuta, de Coimbra e de Lamego) como inquisidores-gerais, concedendo ao rei d. João III a possibilidade de nomear um quarto inquisidor-geral entre os bispos, religiosos ou clérigos seculares formados em teologia ou direito canônico (...) [A implantação contou com o] envolvimento do rei desde o início, assumindo a responsabilidade da criação do tribunal e fazendo questão de estar presente da cerimônia de fundação" (BETHENCOURT, 2000, pp. 24-5). 
obteve liberdade condicional, mas morreu ainda na prisão em julho de 1600 (LUNA, 1997, pp. 62-3).

Em terceiro lugar, cumpre mencionar o aparente desinteresse dos pesquisadores em geral sobre a sua obra. Em recente consulta ao acervo da Universidade de São Paulo ${ }^{45}$, foram localizados menos de quinze trabalhos a seu respeito, somando-se livros, capítulos ou separatas, dissertações e teses. Talvez seja motivo de algum constrangimento para o professor ou pesquisador, mencionar a Prosopopeia - como acidente literário, protocolo didático, obrigação etc. -, sem jamais ter dedicado maior tempo na análise dos versos que lá vão. Jairo Luna convida-nos a estabelecer relações entre o gênero e o narrador fantasioso do poema, atrelado aos preceitos retóricopoéticos:

Notemos a habilidade de Proteu em mudar de forma e sua relação com o jogo retórico. Portanto, extrair múltiplas significações da fala de Proteu é já algo sugerido pela figura deste narrador - "o velho Proteu, que vaticina / Vem numa, e noutra forma peregrina / mudando a natural propriedade" (LUNA, 1997, p. 80).

Esses lances de engenho foram praticamente ignorados não só pelos manuais panorâmicos. O poeta e seu "poemeto" parecem ter se convertido em meros demarcadores temporais. Item de abstração cuja obra, dita "menor", encerraria (ou alimentaria) a equivocadamente chamada "literatura de informação": batismo amargo do demasiado e longo setecentismo luso-brasileiro, como pretendeu Afrânio Coutinho em 1959:

Pero Vaz de Caminha, Anchieta, Nóbrega, Cardim, Bento Teixeira, Gandavo, Gabriel Soares de Sousa, Fernandes Brandão, Rocha Pita, Vicente de Salvador, Botelho de Oliveira, Itaparica, Nuno Marques Pereira, são exemplos da série de cantores da "cultura e opulência", ou autores de "diálogos das grandezas", que constituem essa singular literatura de catálogo e exaltação dos recursos da terra prometida. Essa literatura, diga-se de passagem, não deveria estar longe de emergir de motivos econômicos de valorização da terra aos olhos europeus. A maioria dessas obras não pertence à literatura no sentido estrito, e sua importância decorre de participarem desse ciclo de literatura do descobrimento e de se inclinarem para a terra brasílica, na ânsia que domina a consciência do brasileiro do século XVIII, de conhecê-la, de revelá-la, de expandi-la (COUTINHO, 1983, p. 79).

\footnotetext{
${ }^{45}$ A pesquisa foi realizada em consulta ao portal www.dedalus.usp.br, durante o mês de março de 2018.
} 
Repare-se: Bento Teixeira é comparado com autores de outros tempos e lugares, sem qualquer mediação. Quanto à Prosopopeia, o poema é equiparado a gêneros em prosa que não guardam qualquer relação - temática, estilística e formal - com os seus versos. Daí a conclusão equivocada de que tal "literatura" não estava "longe de emergir de motivos econômicos de valorização da terra aos olhos europeus". Avancemos com paciência pela senda dos manuais didáticos. O poeta sequer é mencionado no capítulo que o futuro "imortal" da ABL, Domício Proença Filho, reservou ao "Barroco" - em estreita paráfrase dos pressupostos de Heinrich Wölfflin. De todo modo, anote-se como o historiador descreve o éthos do poeta "brasileiro", durante o século XVII:

Culto da solidão. O poeta, mais que outros, é um raro, que cria o seu mundo particular e nele se isola. Neste sentido, o Barroco está na raiz do futuro movimento romântico, e convém lembrar que as tendências barrocas penetram pelo controvertido século XVIII, século de entrecruzamento ideológico (PROENÇA FILHO, 1984, p. 140 - grifo do autor). ${ }^{46}$

Três anos depois, Alfredo Bosi alargaria um pouco os predicados do poeta: "[Bento Teixeira] pode ser considerado o primeiro e conhecido exemplo de maneirismo nas letras da colônia (...) A imitação ${ }^{47}$ de Os Lusíadas é assídua, desde a estrutura até o uso de chavões da mitologia e dos torneios sintáticos" (BOSI, 2004, p. 36). Porém, pouco destaque foi dado ao teor dos versos; tampouco foi relativizada a noção de originalidade, que não se aplicaria ao período. Por esses e outros motivos, frequentemente se depara com colegas que esquecem o nome do poeta ou confundemno com "aquele outro" (que nasceu mais de meio século depois) de que resultam esdrúxulas sínteses: "Bento... de Oliveira” ou "Manuel Botelho... Teixeira"? O maior problema não está na fuga do nome à memória, mas no gesto de saltar sobre os versos de quem se fala. Como disse Guilherme Amaral Luz:

\footnotetext{
${ }^{46}$ No mesmo ano em que saiu a primeira edição do manual de Domício Proença Filho, José Aderaldo Castello vislumbraria uma "atitude nativista" na Prosopopeia (CASTELLO, 1967, p. 63).

47 "A Arte Poética horaciana unira com felicidade essas duas noções - a de verossímil, contida em Aristóteles como o resultado da imitação, e a de conveniência, como o pressuposto da persuasão - na noção de decoro, entendida multiplamente como unidade da obra poética adquirida pela concórdia de suas partes em relação tanto à matéria, aos fins, e ao auditório, como ao poeta, e contrária portanto a toda 'monstruosidade' e 'bizarria', desprovidas de ordenação interna, em que os sujeitos e os predicados não se correspondem, em que os termos não se combinam, em que cada parte diverge do todo. É assim que nas preceptivas do seiscentos aquela superação da natureza exigida pelo conceito de verossimilhança acomoda-se a este de conveniência, definindo semelhança de verdade como ordem interna de gênero" (MUHANA, 1996, p. 30).
} 
[...] a crítica literária desenvolvida no Brasil desde o século XIX até pelo menos o último quartel do século $X X$ tratou os textos produzidos na América portuguesa como proto-literatura nacional, cuja suposta falta de "qualidades literárias" não é menos lamentada, na maior parte das vezes, do que a sua falta de "originalidade" e sua "dependência servil" aos cânones da "boa poesia" lusitana (LUZ, 2008, p. 193).

Isso resulta em uma percepção rasa e mecânica sobre o que se produziu no Estado do Brasil, durante o chamado período colonial. Acresce que desconsiderar o poeta e seus versos - devido ao suposto grau de artificialismo, à falta de sinceridade e ao caráter imitativo do poema - permite ao aluno supor que tão ou mais artificial, desonesto e raso será desprezar, sem ler, a obra considerada "inaugural" do "Barroco brasileiro". Dentre outros fatores que supuseram autorizar os especialistas em severos juízos, a matéria principal se refere a dois senões. Um ético; outro, estético. No que diz respeito ao primeiro, durante séculos se afirmou categoricamente que Prosopopeia não passava de imitação menor e ruim da epopeia de Luís Vaz de Camões ${ }^{48}$. Como alerta Adma Muhana:

Devido à principal característica da poesia dos séculos XVI a XVIII, qual seja, pautar-se pela noção de imitação, uma das maiores dificuldades enfrentadas pelos estudiosos é poder desconsiderar fatores de originalidade e subjetividade como critérios de valor para análise dessa poesia, encontrando nos pressupostos da época suas próprias condições de validade (MUHANA, 2003, p. 14).

Não se negam as correspondências, por demais evidentes, com Os Lusíadas. 0 problema consiste em restringir a análise de Prosopopeia a uma comparação formal e depreciativa, em relação a Camões. É curioso que isso tenha acontecido: os entendidos em poesia sabem que a imitação ${ }^{49}$ e a emulação de modelos foram procedimentos usuais (e nada tinham de pejorativo), pelo menos entre a Antiguidade e o final do século XVIII de nossa era. Teria uma parcela da crítica procedido com má-fé ou negligência, pura e simples?

\footnotetext{
48 “Em seu pertinente estudo da Prosopopeia, Fernando Mota insiste em lembrar que há ali mais reminiscências Virgilianas do que Camonianas, colhidas diretamente da Eneida, como também traços de Horácio e Ovídio, que Bento lia com frequência" (FERREIRA, 2001, p. 20).

${ }^{49}$ Maria Fernandes de Carvalho ressalta que, "No final do século XVII, e mesmo na primeira metade do século seguinte, o modelo preceptivo da imitação mantém-se ainda no centro das atenções 'dos versados nas letras humanas'. Vários elementos textuais indiciam essa permanência, entre eles a inclusão de cópias em manuscrito de poemas de autores muito prestigiados, como Francisco de Quevedo, por exemplo, mas também Gôngora e sobretudo Camões" (CARVALHO, 2007, p. 147).
} 
Ao lado da suposta falta de "originalidade" do poeta, residiria outro "defeito", este relativo à composição interessada. $O$ tal arremedo de Camões ${ }^{50}$ não passaria de um "poemeto" (a forma no diminutivo é emblemática) duplamente inferior: 1. por ser versão mirrada da maior epopeia em língua portuguesa; 2. por se tratar de obra "postiça", plena de lugares-comuns, escrita sob encomenda e proteção de Jorge de Albuquerque Coelho, governador e capitão-mor da capitania de Pernambuco. Estaríamos diante de um poema sem predicados, nem substância, que não despertaria qualquer interesse nos leitores de nosso tempo? Há que contextualizar o ambiente que o poeta viveu e as circunstâncias de produção da sua obra. Não se perca de vista que Bento Teixeira residiria "No núcleo de uma sociedade de corte em que o homem culto é signo de representação da sabedoria do governo da monarquia" (CARVALHO, 2007, p. 166).

Essa maneira de ver os homens de outro tempo sob as lupas do anacronismo tende a trazer mais prejuízos e reforçar equívocos do que estimular a curiosidade e aprimorar a capacidade interpretativa dos leitores a caminho.

\section{Sedimentos}

Salvo engano, transcorreu muito tempo para que essas posições cristalizadas pela crítica fossem, senão corrigidas, relativizadas. É emblemático que o poema tivesse acumulado raras edições, ao longo de quatro séculos. A falta de exemplares para consulta dos alunos, porventura curiosos, dificultou a leitura do poema na íntegra, o que favoreceu o contato com os mesmos fragmentos da Prosopopeia - muitas vezes, reproduções de reproduções.

Se não, examinem-se os excertos "selecionados" com que topamos, ao ler os editores do poema e os críticos tardios: Para Antônio Ribeiro, primeiro editor do poema: tratava-se de "algumas rimas de ânimo mais afeiçoado, que poético" (RIBEIRO Apud LUNA, 1997, p. 63). Segundo Francisco Adolfo de Varnhagen, que ainda não tomara

\footnotetext{
50 Como esclareceu Adma Fadul Muhana: "Não dispondo de ações épicas, o Prosopopeia vale-se de 'conceitos' épicos, numa inventio, que, como é previsível, também pisa fundo nas pegadas d'Os Lusíadas. O Prosopopeia se quer sucessor daquele poema épico tanto na composição dos personagens, de suas ações e de suas sentenças, como o poeta se quer Camões. Duarte e Jorge de Albuquerque são daqueles 'altos varões que estão por vir ao mundo', cantados pelo Proteu d'Os Lusíadas, no Canto X, os quais passam a ser protagonistas do poema de Bento Teixeira" (MUHANA, 2003, p. 17).
} 
contato com Bento Teixeira: "Manoel Botelho de Oliveira foi o primeiro brasileiro, que do Brasil mandou ao prelo um volume de poesias" (VARNHAGEN, 1946, p. 24). Em acordo com Ramiz Galvão, em 1873: "não é grande o mérito poético da Prosopopeia" (GALVÃO Apud LUNA, 1997, p. 63). Conforme José Veríssimo (1914), após discorrer sobre o poema que não teria "mérito algum de inspiração, poesia ou forma":

O poeta ou era de si medíocre, ou bem novo e inexperiente quando o escreveu. Confessa aliás no seu Prólogo, já gongórico antes do gongorismo (tanto o vício é da nossa raça) que eram as suas "primeiras primícias" (...) A língua não tem a distinção ou relevo, e o estilo traz já todos os defeitos que maculam o pior estilo poético do tempo, e seriam os distintivos da má poesia portuguesa do século seguinte, o vazio ou o afetado da ideia e a penúria do sentimento poético, cujo realce se procurava com efeitos mitológicos e reminiscências clássicas, impróprios e incongruentes, sem sombra do gênio com que Camões, com sucesso único, restaurara esses recursos na poesia de seu tempo (VERÍSSIMO, 1963, pp. 30-1).

Para Ronald de Carvalho (1919), Prosopopeia não passaria de:

[...] um poema de medíocre feitio, composto em verso endecassílabo, em louvor dos feitos e das virtudes do terceiro donatário de Pernambuco. Nas suas noventa e quatro estrofes, em oitava rima, não se percebe um grande sopro de inspiração, nem, ao menos, qualquer relevo de estilo. É uma fraca imitação dos processos camonianos, sem o brilho e sem a elevação dos Lusíadas. Há frequentes indecisões na expressão, muita mesquinhez de estro e de linguagem, e raras partes de boa poesia. Em todo caso, atendendo-se ao acanhamento do meio, não se deve desprezar esse primeiro fruto, enfezado e insípido, da literatura brasileira (CARVALHO, 1968, pp. 78-9).

Em acordo com Manuel Bandeira (1946): “Nenhum valor literário apresenta, quer pelo conteúdo, mera sucessão de lisonjas bombásticas ao 'sublime Jorge', que o autor, pelos olhos de Proteu, vê 'com braço indômito e valente, / A fama dos antigos eclipsando', quer pela forma, canhestro decalque das dicções camonianas" (BANDEIRA, 2009, p. 10).

Já para Galante de Sousa:

Do ponto de vista estético, a Prosopopeia não resiste a uma análise menos superficial. Talvez por isso mesmo, salvo neste ou naquele particular, sua fortuna crítica tem sido pouco acidentada. Não tivesse o poema por si a marca de primeira manifestação, em letra de forma, da literatura no Brasil e a suposta nacionalidade brasileira do autor, cuja incógnita biográfica desafiou a pesquisa 
por tanto tempo, e teria passado ao esquecimento sem grave prejuízo para o nosso patrimônio literário (SOUSA, 1972, pp. 22-3).

Na década de 1980, Luiz Roberto Alves foi um dos primeiros a vislumbrar outros aspectos, para além da condenação prévia:

O texto épico é dirigido aos influentes, sim, porque não poderia, naquele contexto, ser dirigido aos pobres. Ora, o poeta que reclama da falta de acomodação dos meios entre o Rei e seus notáveis servidores e faz notas injustiças cometidas contra réus da Inquisição não é capaz de ter "abertura de alma" maior para apontar em seus escritos a chacina dos índios e a escravidão dos negros (ALVES, 1983, p. 129).

Nos anos de 1990, o pesquisador Jairo Luna percebeu que "A crítica desde Varnhagen tem visto no poema um mero poema laudatório à exceção, talvez, somente de Afrânio Peixoto e Sílvio Romero. Mas o poema tem elementos a demonstrar uma habilidade retórica em favor de um poeta em difícil situação política" (LUNA, 1997, p. 78). Kênia Pereira leva em conta a criticidade do poeta:

Podemos mesmo afirmar que Bento Teixeira, com toda sua ousadia e "heresias", acabou por se impor como um dos primeiros e autênticos representantes do pensamento crítico no Brasil, numa época hostil a todo questionamento que fugisse ao controle religioso. Declarava abertamente suas preferências literárias e religiosas. Representava, portanto, um indivíduo perigoso nessas plagas católicas. Cristão-novo, professor, comerciante, advogado, polemista, Bento Teixeira sacudiu a sonolência da pacata colônia (PEREIRA, 1998, pp. 63-4).

Em 2007, Alexei Bueno reverberava uma das vertentes críticas: “Apesar da grande dívida camoniana e dos objetivos encomiásticos, a Prosopopeia, composta por 94 oitavas, é menos fraca do que a fama que deixou, possuindo mesmo algumas estrofes admiráveis" (BUENO, 2007, p. 20). Embora reconheça a qualidade de algumas estrofes, não procede a uma análise detida das partes a que se referira. A amostra talvez seja pequena, mas diz a que os estudiosos vieram.

Durante séculos, Prosopopeia correu o risco de se tornar caricatura: poema a servir de chacota pseudoanalítica. Acometido pela síndrome do muito de que se diz e pouco se lê, raros tiveram acesso ao poema e, quando isso aconteceu, restituíram a apostila ou o manual de "literatura brasileira" com a sensação de que os versos confirmavam o que de pior se havia dito: pequena qualidade estética, ética questionável do autor etc. Durante séculos, ecoaram os conhecidos lugares-comuns, repisados com 
força desde meados do Oitocentos: poema "artificial", "rebuscado", com "excesso" de metáforas - espécie de réplica subserviente e piorada de Os Lusíadas. Ora, a metáfora era ingrediente desejável no fazer poético, entre os letrados do século XVI e XVII. Será possível estipular métricas que permitam afirmar qualidades ou retirar o mérito de um poeta daquele tempo? Como se sabe, a tradição retórico-poética estava no horizonte dos poetas, como salienta João Adolfo Hansen:

Horácio valoriza a visão em detrimento da audição e, confirmando-o, Possevino afirma que a poesia, arte de imitação como a pintura, e imagem: assim como o pincel imita os topoi narrativos das ecfrases de autoridades, também a pena deve imitar o pincel, produzindo metáforas visualizantes de efeitos maravilhosos, simultaneamente adequados à utilidade e ao prazer. Lembra, neste sentido, que os gregos chamavam de graphein o verbo relativo a faculdade do desenho, significando com ele tanto o figurado pela mão na forma de letras e linhas, quanto o expresso pela voz em palavras. Possevino entende "desenho" como o resultado exterior do desenho interno ou conceito. $\mathrm{Na}$ doutrina do engenho seiscentista, que opera a invenção retórico-dialética do desenho, a tópica de Possevino é intensificada (HANSEN, 1997, p. 179).

Ao que tudo indica, embora Bento Teixeira seja pouco conhecido, ainda costuma ser julgado severamente a partir de um punhado de versos (quase sempre os mesmos) que os antologistas reproduziram - talvez inclinados pela obediência à tradição, porventura com o intuito de engrossar uma espécie de cânon de segunda ordem, sem lugar para o poema/imitação. É irônico que os mesmos detratores do poeta, a proclamar a "falta de originalidade" e "autenticidade"51 do poema (o que também diria respeito ao caráter do autor) - valores inaplicáveis para a poesia produzida no século XVII procedam de modo similar ao copiarem o que disseram seus colegas de ofício. A ironia maior está em constatar que cada crítico pretende apresentar as "melhores" obras ou as mais "representativas" ao consulente. Terá havido trabalho de seleção? Ou mera reapropriação do que se disse, sem detido exame?

\footnotetext{
${ }^{51}$ Observa Adma Muhana: “[...] se 'verdade' significa adequação das coisas ditas ou pintadas às coisas da natureza, as coisas tornadas poesia não são verdadeiras (podendo-o ser apenas alegoricamente). Porém, as coisas que se tornam poesia são verdadeiras no sentido em que são conformes à razão, podendo por isso ser ditas naturais e perfeitas. Esta perfeição, que é algo a ser atingido pelo aperfeiçoamento da imitação poética, é ainda uma perfeição das coisas naturais - exatamente como a perfeição de um homem não está no recém-nascido, mas no adulto" (MUHANA, 1996, p. 19).
} 


\section{Análise}

Ao reverberar o que possíveis leitores registram desde meados do século XIX - a exemplo de Francisco Adolfo de Varnhagen, Sílvio Romero e José Veríssimo - critérios aplicados a outros poemas foram desprezados na leitura deste. Ora, as lentes da crítica oitocentista parecem desconsiderar o contexto em que o poema foi composto. Maria Fernandes de Carvalho avalia que:

No âmbito da poesia do século XVII, tanto as composições líricas quanto suas contrafações jocosas alimentam o sistema retórico-poético em que são compostas. Fundamentada na concepção de arte em que a imitação (imitatio) é a base da composição poética, a poesia seiscentista reproduz os padrões da cultura letrada. Com efeito, a prática das letras cultas em que se inscreve persegue certo modelo preceptivo de realização aguda, que busca a perfeita congruência entre coisas e sua representação por palavras, princípio previsto na Poética de Aristóteles (CARVALHO, 2007, p. 45).

De que trata Prosopopeia? A que gênero pertence? De que modo o poeta estruturou os versos? Como se combinam as rimas? Há variações na metrificação? Como o poeta ressalta o ritmo, de maneira a assegurar o andamento dos versos? Como avaliar o intertexto com a epopeia de Camões? De que maneira o poeta manifesta seu suposto apreço pelo governador? Comecemos pelo "Prólogo" ao poema:

[...] eu, querendo dibuxar com obstardo pinzel de meu engenho a viva Imagem da vida e feitos memoráveis de vossa mercê, quis primeiro fazer este riscunho, pera depois, sendo-me concedido por vossa mercê, ir mui particularmente pintando os membros desta Imagem, se não me faltar a tinta do favor de vossa mercê, a quem peço, humildemente, receba minhas Rimas, por serem as primícias com que tento servi-lo (TEIXEIRA, 1977, pp. 32-3).

Lê-se, em diversos manuais de "literatura", que o próprio poeta teria confessado a sua incapacidade em compor poesia de melhor qualidade, tendo em vista a afirmação de que se trataria de um "rascunho", desenhado com "limitado pincel do engenho". Deve-se ressaltar que o texto alude a Horácio, que propunha analogias entre a pintura e a a poesia. Em diálogo com Robert Klein, João Adolfo Hansen ressalta que:

Generalizando-se as conclusões de [Robert] Klein, pode-se estabelecer a homologia dos procedimentos técnicos de produção das empresas e emblemas de seu estudo com os da poesia, da oratória ou da pintura do século XVII. E, com isso, propor-se que as doutrinas da agudeza conceituosa tem por primeiro postulado, também na América Portuguesa e Espanhola, o caráter universal do 
disegno. O disegno é, no trocadilho italiano, segno de Dio, signo de Deus na mente, mais ainda nos lugares contrarreformados, em que a doutrina católica da luz natural da Graça infusa na natureza e na história, difundida então principalmente pela Cia. de Jesus, orienta a representação com as analogias de proporcionalidade, de proporção e de atribuição da Substância participada nas linguagens (HANSEN, 1997, p. 178).

Evite-se, portanto a leitura aligeirada e parcial, que desconsidera as fórmulas previstas para captação da benevolência (captatio benevolentiae), utilizadas pelos autores na composição de suas obras, por sinal, situadas em determinado tempo e lugar. Como observou Marcello Moreira:

O topos "modéstia afetada" instaura-se por meio de um símile apresentado no "Prólogo": assim como dista o rascunho da pintura já acabada, assim distam as primeiras rimas do poeta de um poema consumado. As "primícias" que o poeta oferece, por serem primícias, são aceitas devido à benevolência que caracteriza o sujeito a quem são dedicadas. A benevolência e a brandura de Jorge de Albuquerque Coelho são retoricamente constituídas anteriormente ao efeito que se deseja produzir, ou seja, a aceitação da dedicatória por parte do mesmo Jorge de Albuquerque Coelho (MOREIRA, 2008, p. 102).

Afinal, como assegurar que era o "homem" Bento Teixeira que estava a confessar a sua reduzida incapacidade em escrever? Seria este um convite eficaz, se lido com as lentes moralistas do século XIX e XX? Ainda que aceitássemos a ressalva do poeta como verdadeira, sua deficiência não o teria impedido de endereçar a Prosopopeia ao governador? Talvez fosse mais consistente com as preceptivas daquele tempo interpretar o que diz o "Prólogo" como discurso afetado, produzido por uma persona humilde, que reafirma o seu modesto lugar na hierarquia do reino. Sob essa perspectiva, ao fingir defeitos de composição, a voz (delegada pelo poeta à persona assumida no poema) ressaltaria, justamente por contraste, os grandes feitos (épos) ${ }^{52}$ do governador - narrados em seguida:

E vós, sublime Jorge, em quem se esmalta

A Estirpe d'Albuquerques excelente,

\footnotetext{
52 “A finalidade principal da epopeia é o prazer decorrente da admiração das res gestae, 'coisas feitas' que efetuam o kleos ou a fama, como se lê na definição do gênero que Horácio formula na Arte Poética [...] De Aristóteles até o século XVIII, o gênero é doutrinado como discurso longo, quase sempre em verso heroico, o hexâmetro datílico grego e latino, ou na oitava rima italiana de verso decassílabo com as seis primeiras rimas alternadas e as duas últimas emparelhas ( $A B A B A B C C$ ) das línguas vulgares, imitando por modo misto, narrativo e dramático, a ação una, inteira e perfeita, de tipo superior, ilustre ou heroico, metido em guerra histórica ou mítica, real ou fictícia, para a admiração, o prazer e o ensino de virtudes cívico-morais" (HANSEN, 2008, p. 27).
} 
E cujo eco da fama corre e salta

Do Cauro Glacial à Zona ardente,

Suspendei por agora a mente alta

Dos casos vários da Olindesa gente,

E vereis vosso irmão e vós supremo

No valor abater Querino e Remo.

(Canto III - TEIXEIRA, 1977, p. 36)

Denominado como "sublime" - portanto, situado acima dos homens ordinários -, Jorge de Albuquerque Coelho refletiria (o verbo "esmaltar" assume essa conotação) a excelente procedência de seus antecessores. O éthos heroico do governador suscitaria o emprego de hipérboles, como previa o gênero épico. A sua fama já seria tamanha que o seu nome cobriria do Polo Norte ao Trópico de Câncer. Homem de feitos heroicos, ao lado de seu irmão, superaria o valor de Rômulo e Remo (fundadores de Roma) e seus feitos facultariam esquecer episódios que se passaram em Olinda.
As Délficas irmãs chamar não quero, que tal invocação é vão estudo;
Aquele chamo só, de quem espero
A vida que se espera em fim de tudo.
Ele fará meu Verso tão sincero,
Quanto fora sem ele tosco e rudo,
Que per rezão negar não deve o menos
Quem deu o mais a míseros terrenos.
(Canto II - TEIXEIRA, 1977, p. 35)

Simultaneamente, a voz que entoa os versos recusa-se a invocar as musas, como mandava a tradição poética, por se tratar de procedimento feito em vão. Segundo Marcelo Moreira, "declara-se o catolicíssimo propósito de não apelar às délficas irmãs, pois só se pode esperar inspiração, já compreendida cristãmente, como a participação na graça infusa" de Deus (MOREIRA, 2008, p. 95). Desse modo, em vez de referir-se à morada de Apolo, em Delfos, recorre à figura solitária de Deus, no Céu, que poderia conceder afetada sinceridade, gravidade e elegância aos versos. Ao interpretar a segunda oitava rima de Prosopopeia, Jairo Luna estabeleceu relações o repertório do poeta, recusando-se a invocar as musas - como rezava a tradição poética - também como forma de resistir à perseguição católica:

O poema de Bento Teixeira já abre com uma pequena novidade, o poeta recusa as musas da tradição em favor de uma inspiração de fonte católica, o que segundo Anazildo Vasconcelos é só um jogo retórico. Observemos, porém, que 
o poeta deve realmente ter utilizado e muito dos seus conhecimentos de retórica, tendo em vista a sua situação real, sempre de tensão, provocada pela Santa Inquisição (LUNA, 1997, p. 69).

A aparente recusa em invocar as deusas do Olimpo é ratificada a seguir:

\author{
Não quero no meu Canto algũa ajuda \\ Das nove moradoras de Parnaso, \\ Nem matéria tão alta quer que aluda \\ Nada ao essencial deste meu caso. \\ Porque, dado que a forma se me muda, \\ Em falar a verdade serei raso, \\ Que assim convém fazê-lo quem escreve, \\ Se à justiça quer dar o que se deve. \\ (Canto XXIV - TEIXEIRA, 1977, p. 47)
}

Referindo-se às nove musas de Apolo, a voz que narra sugere estar mais preocupada em dizer verdades de modo humilde ("serei raso"), como "convém" a "quem escreve". Ao pronunciar-se deste modo, a estrofe alude ao decoro poético. Ou seja, o poeta aplica à matéria que escreve a modéstia que convém ao narrador, também como sinal de sua pretensa fidelidade aos fatos. No transcorrer da "Narração" (terceira parte do poema), sucedem-se numerosas metáforas que, entre outras coisas, visam a demonstrar o engenho do poeta, capaz de promover analogias agudas:

\footnotetext{
A Lâmpada do Sol tinha encuberto, Ao Mundo, sua luz serena e pura, E a irmã dos três nomes descuberto A sua tersa e circular figura.

Lá do portal de Dite, sempre aberto, Tinha chegado, com a noite escura, Morfeu, que com subtis e lentos passos Atar vem dos mortais os membros lassos. (Canto VII - TEIXEIRA, 1977, p. 38)
}

A luz da lua ("irmã dos três nomes") cheia ("tersa e circular figura") substitui a luz diurna ("serena e pura"). É durante a noite que o discreto Morfeu, filho de Hipnós, concede descanso aos mortais (de "membros lassos"), através do sono reparador. A viagem prossegue. Dois cantos à frente, já em alto-mar, os navegantes parecem trilhar o céu - refletido na água: 
As luzentes Estrelas cintilavam,

E no estanhado Mar resplandeciam,

Que, dado que no Ceo fixas estavam,

Estar no licor salso pareciam.

Este passo os sentidos comparavam

Àqueles que d'amor puro viviam,

Que, estando de seu centro e fim absentes,

Com alma e com vontade estão presentes.

(Canto IX - TEIXEIRA, 1977, p. 39)

Bento Teixeira denomina o Oceano de "estanhado Mar", a sugerir a imediata associação entre Mar, Estrela e estanho - novo exemplar de agudeza. Para que a água adquirisse feição "estanhada" deve-se supor que o céu estivesse bastante limpo, o que permitiria aos tripulantes enxergar grande quantidade de estrelas. Reunidos em cópia, os astros não só se refletem no oceano; emprestam-lhe a coloração do metal estanho. A imagem não só provoca admiração dos navegantes; afeta os sentidos, a ponto de evocar o estado do homem apaixonado (excêntrico no comportamento; centrado espiritualmente). O rebaixamento programático da Prosopopeia parece injusto, também, quando se atenta para a explicação metrificada do nome dado a Pernambuco ${ }^{53}$ :

É este porto tal, por estar posta Ũa cinta de pedra, inculta e viva, Ao longo da soberba e larga costa, Onde quebra Neptuno a fúria esquiva. Antre a praia e pedra descomposta, $O$ estanhado elemento se diriva Com tanta mansidão, que ũa fateixa Basta ter à fatal Argos aneixa.

(Canto XVIII - TEIXEIRA, 1977, p. 43)

Em o meio desta obra alpestre e dura, Ũa boca rompeo o Mar inchado, Que, na língua dos bárbaros escura, Paranambuco de todos, chamado. de Para'na, que é Mar; Puca, rotura, Feita com fúria desse Mar salgado, Que, sem no dirivar cometer míngua, Cova do Mar se chama em nossa língua. (Canto XIX-TEIXEIRA, 1977, p. 44)

\footnotetext{
${ }^{53}$ Uma “insossa descrição do Recife”, segundo Alceu de Amoroso Lima (1959, p. 23).
} 
Um cinturão de rochas quebra a força das ondas, suspende a direção das correntes e divide o mar (em cor de estanho) a se dividir, de maneira que com apenas uma âncora se interrompe o curso da embarcação. Repare-se que, na boca de Proteu, seres da mitologia grega ganham relevo, o que evidencia o contraste com o que prometia o poeta, nos versos iniciais, de não invocar as musas; apenas o Senhor. A narração está em disputa.

O poema representa a gradativa aproximação dos tripulantes à costa pernambucana. A seguir, a antiga tópica da inconstância do mundo é evocada. Não se trata de mera reprodução de Camões, mas da presença constante de modelos retirados da auctoritas, ou seja, de invocar os gregos e latinos (especialmente Homero e Virgílio). Eles autorizariam o versejador luso-brasileiro a se referir ao repertório comum aos demais poetas e, por extensão, dos leitores experimentados em versificação.

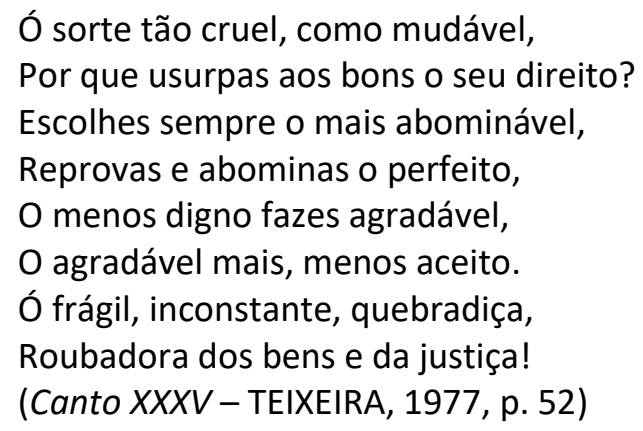

A aventura prossegue. Como se disse, Rômulo e Remo estão redivivos nos irmãos Albuquerque. A comparação decorre da intenção de elogiar o protagonista. A hipérbole não implica defeito; sugere que o poeta segue os protocolos do gênero encomiástico. Virtuosos, devido à bravura que os aproxima moralmente, os irmãos serão resgatados do cativeiro não pela grande quantidade de dinheiro, mas pelo destino fatal reservado a Duarte Coelho.

Eis ambos os irmãos em captiveiro.

De Peitos tão protervos e obstinados, Por cópia inumerável de dinheiro Serão (segundo vejo) resgatados. Mas o resgate e preço verdadeiro, Por quem os homens foram libertados, Chamará neste tempo o grão Duarte, Pera no claro Olimpo lhe dar parte. (Canto LXXXIX - TEIXEIRA, 1977, p. 79) 
Os principais tratados de poética da Antiguidade - localizados e reeditados ao final da Idade Média -, ensinavam que a metáfora era um dos esteios da composição em versos que se pretendesse aguda. Esse é um dos pilares para melhor compreender a concepção, o método e os objetivos de Bento Teixeira, ao redigir a Prosopopeia:

A existência da Poética [de Aristóteles] impõe para o século XVI o reconhecimento de que, para além dos recursos retóricos (comuns aos discursos históricos, epistolares e panegíricos), a poesia dispõe de uma identidade que regula e autoriza o discernimento entre um poema perfeito e outro imperfeito. A questão que o ressurgimento da Poética de Aristóteles coloca para o quinhentismo é a do aparecimento de uma preceptiva acerca da poesia, que, no trívio medieval, não detinha lugar próprio, oscilando entre os campos da gramática e da retórica. No caso da poética, sendo ela uma tekhné, seu fim é apreender a composição da poesia (MUHANA, 1996, p. 6).

Como esclarece Maria Fernandes Carvalho: “O efeito da metáfora é equiparado ao de um silogismo específico, o entimema. Sua eficiência depende assim da rapidez de sua estrutura não-comparativa; além disso, se a metáfora portar uma relação de antítese é melhor apreendida e, por último, melhor ainda se sua expressão gerar imagens realçantes" (CARVALHO, 2007, p. 53). Na Prosopopeia, vários são os momentos em que a arte, ou seja, a soma de procedimentos (artifícios) aplicados conscientemente pelo poeta, resultaram na aproximação de coisas maximamente distantes. De acordo com Adma Muhana:

Todas as agudas e encarecedoras construções metafóricas que o poema apresenta visam assim evidenciar o conhecimento que o poeta tem da arte, isto é, sua familiaridade com a técnica poética, ao mesmo tempo que provam sua condição de letrado (embora morador da capitania de Pernambuco...), êmulo dos poetas latinos antigos e do já grande poeta português moderno. Isto é, Bento Teixeira, poeta, escreve para leitores cultos, ledores de Virgílio, Ovídio e, principalmente, Camões (MUHANA, 2003, p. 15).

Um dos critérios para se aferir qualidade técnica ao poema consistia em demonstrar ao leitor/ouvinte a seleção e combinação de palavras que provocassem estranhamento, do ponto de vista material, sonoro e semântico. Longe de revelar obsessões (ou neuroses anacrônicas) do poeta, acometido pela dicotomia religiosa ou pelo exílio forçado no Estado do Brasil, a reincidência de alguns termos reitera a constituição de imagens pretendidas. De um lado, o poema reafirma o pacto de 
sujeição ${ }^{54}$ entre o homem letrado e a Coroa; de outro, reelabora a fidelidade do poeta aos preceitos católicos. Como salienta Maria do Socorro Fernandes de Carvalho:

Postulado de determinada representatividade social, a excelência nas letras é primeiramente perfeição retórica. Sabemos que esse espelho de virtudes fundase na definição de que todo belo é virtuoso, fonte da prática oratória do elogio (...) na prosa ou na poesia, confere-se amplo respaldo ao domínio da locução letrada, veiculada pelo ensino e emulação de autoridades. Indicativo da prudência de todo autor é conhecer as ocasiões quanto a lugar, matéria, fins, destinatário e artifícios para a construção das agudezas (CARVALHO, 2007, p. 167).

A simultaneidade de intenções não impediria que o poeta compusesse versos de qualidade estética. Graças ao seu engenho, Prosopopeia não só logra o acabamento calculado por Bento Teixeira; contempla os protocolos de leitura dos raros homens letrados que viveram naquele tempo. Um exame mais detido dos versos facultaria ao leitor rever a má vontade dos críticos e reposicionar-se diante do texto. Comecemos pelo título, que responde por um verdadeiro anedotário, na experiência dos professores, dentro e fora da sala de aula. Costuma-se traduzir que Prosopopeia como a personificação de seres irracionais. Raramente se considera estar diante de uma modalidade discursiva em que a palavra, sob o domínio e a voz de entidades sobrehumanas, porque o poeta equipara o herói (Jorge de Albuquerque) aos deuses grecolatinos. Segundo Adma Muhana:

[...] o Prosopopeia se constitui uma "prosopopeia" de Proteu55: figura de linguagem pela qual o poeta faz falar seres fictícios. Descrição do recife de Pernambuco, matança de índios, naufrágio, fracasso na guerra, tudo se unifica não na "vida" de Jorge de Albuquerque, mas, projetado sempre para o futuro, no relato fantástico feito por Proteu de fundação da Nova Lusitânia, iniciada com um épico que só se realizará quando novos feitos forem cumpridos. Ainda

\footnotetext{
${ }^{54}$ Bento Teixeira escrevia sob o contexto teológico-político do reino português, que, "[...] como diria Kantorowicz, é monarquia mística organizada sobre bases racionais. Em sua doutrina, a abdicação do poder por parte do corpo político é quase total, sendo interpretada como a largitio ou a quasi alienatio suareziana: como um único corpo místico de vontades unificadas, a vontade coletiva subordina-se ao pactum subjectionis, que funda a hierarquia natural dos privilégios e a sacralidade da persona mystica ou ficta do rei, dotando-se o poder temporal dos atributos sagrados da transcendência de que o papa é o vigário ou Vice-Cristo (HANSEN, 1994 p. 15).

55 Jairo Luna salienta que "[...] o poeta constrói um poema como se fosse uma profecia ditada por uma divindade pagã sobre o herói de um reino cristão, tendo, porém, o poeta invocado o Deus cristão para bem escrever seus versos. Lembremos que o dom de profetizar era considerado pela Santa Inquisição como prática de bruxaria, motivo que se comprovado, poderia levar o réu à morte pela fogueira" (LUNA, 1997, pp. 71-2).
} 
que no presente o que se vê seja barbárie, desordem, derrota (MUHANA, 2003, p. 17).

Poema em que o artifício faz máxima morada, resultaria daí a impressão de que a matéria do poema é indigna e que o texto resulte frio ou sem cor. Como atribuir impessoalidade e plágio a um poema em que o propósito de ser pessoal e original jamais esteve em questão? Passemos às cinco partes de que o poema se compõe. A edição publicada por Ivan Teixeira em 2008 revela que Prosopopeia se divide em seções, com número "irregular" de estrofes. A maneira como o poema foi estruturado guardaria relação com o teor de seus versos? Parece que sim. Dirigido ao governador da capitania de Pernambuco, Prosopopeia articula-se em torno do caráter e das ações atribuídas ao governante.

As principais figuras evocadas no poema são os heróis portugueses, empenhados em proteger o reino e expulsar os holandeses, com vistas a fortalecer o comércio açucareiro com a metrópole e preservar o território, estratégico para a circulação dos missionários e o "acrescentamento" da fé - premissa encontrada desde os primeiros relatos de viagem sobre o Brasil. Igualmente parco e rasteiro será atribuir ao poema épico intenções que provavelmente não ocorriam ao autor e aos homens letrados de seu tempo. Ao fazer de Albuquerque protagonista de seus versos, Bento Teixeira não procedeu de modo nem indigno, nem "inovador". A prática de dedicar obras a autoridades da extensa hierarquia reinol pressupunha a composição encomiástica, gênero adequado ao elogio ou vitupério. Como notou Guilherme Amaral Luz:

[...] a "boa literatura" seria aquela que mais edifica o leitor discreto, fazendo-o reconhecer os modelos de virtude (emulados no homenageado exemplar) que veicula. Por conseguinte, quanto mais o homenageado reconheça valores políticos em seu retrato poético, maior sua lisonja e sua gratidão com o "poeta". A questão que aqui se coloca, portanto, não é se as virtudes do homenageado correspondem ou não às suas atitudes efetivas, mas se elas correspondem ou não ao que se espera de alguém da sua posição em uma cultura política particular. No caso de Jorge d'Albuquerque Coelho e de seu irmão, Duarte Coelho, homenageados de Prosopopeia, deve-se buscar retratos de virtudes, desenhados ut pictura poesis, capazes de produzir efeitos sobre os leitores discretos aos quais se destinam. É preciso perceber as "personagens" como espelhos da nobreza e não como indivíduos psiquicamente singulares (LUZ, 2008, p. 198). 
Isso tanto ocorreu nos relatos de viagem, quanto nos poemas de José de Anchieta, que utilizavam a língua geral; tanto se percebe nos sermões do conselheiro real de Dom Pedro IV, Antônio Vieira, quanto nos versos de Basílio da Gama, dedicados ao Marquês de Pombal; tanto no Caramuru, de Santa Rita Durão, quanto nos indianíssimos versos, longamente declamados pelo cosmopolita Gonçalves de Magalhães ao Imperador Dom Pedro I do Brasil, seu mecenas. Portanto, Bento Teixeira não pode ser depreciado à luz de sua menor "originalidade", tampouco pelo fato de ter produzido versos atinentes aos preceitos do encômio, como previam os manuais de retórica e poética, largamente conhecidos e seguidos por diversos homens letrados de seu tempo e depois dele. Guilherme Amaral Luz adverte que:

[...] não há motivos para negar que os versos laudatórios seiscentistas se ligam à formação de laços ("clientelares") entre escritores e "nobres". Os panegíricos, os encômios e as diversas formas de dedicatórias não são estranhos à sociedade de corte, na qual os valores dos varões se medem pela sua fama pública e pelos louvores aos seus feitos. Nesse sentido, o valor poético de tais exemplares textuais não se pode isolar da política personalista e palaciana do "Antigo Regime" (LUZ, 2008, p. 197).

Não haverá seriedade, nem consistência, em denominar Bento Teixeira como "sub-Camões" (MARTINS, 1978, p. 109), mesmo porque seria difícil provar que o poeta exilado em Pernambuco tivesse alguma pretensão de soar exatamente como o poeta do rei Dom Manuel. Prosopopeia dialoga com a longa tradição épica (sem se restringir a Os Lusíadas), o que explica a presença de seres mitológicos e a emulação com os autores que vieram antes. Talvez fosse mais viável compreender o poema como um exercício de cortesia ao governador José de Albuquerque Coelho: pequena virtude de homem letrado, que aludia às referências culturais do período em que viveu. 


\section{Bibliografia}

ALVES, Luiz Roberto. Confissão, poesia e inquisição. São Paulo: Ática, 1983.

AMORA, Antônio Soares. A Prosopopeia, de Bento Teixeira, à luz da moderna camonologia. Lisboa: Universidade de Lisboa, 1957, 11p.

ARISTÓTELES. Poética. $3^{\mathrm{a}}$ ed. Tradução de Ana Maria Valente. Lisboa: Fundação Calouste Gulbenkian, 2008.

BANDEIRA, Manuel. Apresentação da poesia brasileira: seguida de uma antologia. São Paulo: Cosac Naify, 2009.

BETHENCOURT, Francisco. História das Inquisições: Portugal, Espanha e Itália - séculos XV-XIX. São Paulo: Companhia das Letras, 2000.

BOSI, Alfredo. História concisa da literatura brasileira. 42ª ed. São Paulo: Cultrix, 2004.

BUENO, Alexei. Uma história da poesia brasileira. Rio de Janeiro: G. Ermakoff, 2007.

CARVALHO, Maria do Socorro Fernandes de. Poesia de agudeza em Portugal: estudo retórico da poesia lírica e satírica escrita em Portugal no início do século XVII. São Paulo: Humanitas; Edusp, 2007.

CARVALHO, Ronald de. Pequena história da literatura brasileira. $13^{\mathrm{a}}$ ed. Rio de Janeiro: F. Briguiet \& Cia. Editores, 1968.

CASTELO, José Aderaldo. Manifestações literárias da era colonial. São Paulo: Cultrix, 1967.

COUTINHO, Afrânio. Introdução à literatura no Brasil. $11^{\text {a }}$ ed. Rio de Janeiro: Civilização Brasileira, 1983.

FERREIRA, Luzilá Gonçalves. Apresentação. In: PILOTO, Afonso Luiz; TEIXEIRA, Bento. Naufrágio \& Prosopopeia. Recife: Editora Universitária da UFPE, 2001, pp. 7-28.

HANSEN, João Adolfo. Prefácio. In: PÉCORA, Alcir. Teatro do sacramento: a unidade teológico-política dos sermões de Antônio Vieira. Campinas: Editora da Unicamp; São Paulo: Edusp, 1994, pp. 15-36.

Ut pictura poesis e verossimilhança na doutrina do conceito no século XVII colonial. Revista de Crítica Literária Latino-Americana, Ano XXIII, n. 45, pp. 179-191, Lima-Berkeley, 1997.

Notas sobre o gênero épico. In: TEIXEIRA, Ivan (org.). Épicos. São Paulo: Edusp; Imprensa Oficial, 2008, pp. 17-91. 
LIMA, Alceu de Amoroso. Quadro sintético da literatura brasileira. Rio de Janeiro: Agir, 1959.

LIPINER, Elias. Os judaizantes nas capitanias de cima (estudos sobres os cristãos-novos do Brasil nos séculos XVI e XVII). São Paulo: Brasiliense, 1969.

LUNA, Jairo. Retórica da poesia épica. Dissertação de Mestrado. São Paulo: FFLCH/USP, 1997.

LUZ, Guilherme Amaral. O canto de Proteu ou a corte na colônia em Prosopopeia (1601), de Bento Teixeira. Niterói: Tempo, vol. 13, n. 25, pp. 193-215, 2008.

MARTINS, Wilson. História da Inteligência Brasileira. Volume I (1550-1794). São Paulo: Cultrix, 1978.

MELLO, José Antônio Gonsalves de. Bento Teixeira, autor da Prosopopeia. In: Estudos pernambucanos. $2^{\mathrm{a}}$ ed. Recife: Fundarpe, 1986, pp. 13-52.

MOREIRA, Marcello. Louvor e história em Prosopopeia. In: TEIXEIRA, Ivan (org.). Épicos. São Paulo: Edusp; Imprensa Oficial, 2008, pp. 95-117.

MUHANA, Adma Fadul. A epopeia em prosa seiscentista: uma definição de gênero. Tese de Doutorado. São Paulo: FFLCH/USP, 1996.

O Prosopopeia de Bento Teixeira: epopeia de derrotas. In: Anais do XIX Encontro Brasileiro de Professores de Literatura Portuguesa - Imaginário: o não-espaço do real. Curitiba: 2003, pp. 14-19.

PEREIRA, Kênia Maria de Almeida. Um rápido olhar sobre nosso primeiro poeta épico. Linguagem - Estudos e Pesquisas (UFG/Catalão), vol. 1, n. 1, pp. 9-26, 1997.

A poética da resistência em Bento Teixeira e Antônio José da Silva, o Judeu. São Paulo: Annablume, 1998.

PROENÇA FILHO, Domício. Estilos de época na literatura: através de textos comentados. $8^{\text {a }}$ ed. São Paulo: Ática, 1984.

SOUSA, J. Galante de. Em torno do poeta Bento Teixeira. São Paulo: IEB/USP, 1972.

TEIXEIRA, Bento. Prosopopeia. 9a ed. São Paulo: Melhoramentos, 1977 [Introdução, Estabelecimento do texto e Comentários por Celso Cunha e Carlos Durval].

VARNHAGEN, Francisco Adolfo de. Florilégio da poesia brasileira. Tomo I. Rio de Janeiro: Academia Brasileira de Letras, 1946.

VERÍSSIMO, José. História da Literatura Brasileira. 4ª ed. Brasília: Editora da UnB, 1963. 
VILAR [de CARVALHO], Gilberto. O primeiro brasileiro: onde se conta a história de Bento Teixeira, cristão-novo, instruído, desbocado e livre, primeiro poeta do Brasil, perseguido e preso pela Inquisição. São Paulo: Marco Zero, 1995. 


\section{"Pictórico", categoria do Seiscentos?}

Resumo: Neste artigo propõe-se analisar a acepção de "Pictórico", nos moldes como o termo foi entendido por manuais brasileiros de literatura publicados no século XX. $O$ dado imagético não se restringe ao período chamado "Barroco", tampouco define o movimento a que determinados autores foram atrelados. $\mathrm{Na}$ análise, recorre-se a manuais da Antiguidade grecolatina e da Era Moderna que defendiam a pintura e a literatura como artes análogas.

Palavras-Chave: Literatura Brasileira, Periodização, Barroco, Arcadismo.

Abstract: This article intends to analyze the meaning of "Pictorial", as the term was understood by Brazilian literature manuals published in the twentieth century. The imagistic element is not restricted to the period called "Baroque", nor defines the movement that certain authors was connected. In the analysis, we have used Greek-Latin Antiquity and Modern Age's manuals which is used to defend the painting and the literature like analogous arts.

Keywords: Brazilian Literature, Periodization, Baroque, Arcadianism, Pictorial.

Nos manuais brasileiros de literatura editados ao longo do século XX prevalece a concepção de "Barroco" como movimento de longa duração, proveniente da Itália renascentista e da Espanha dourada, que, em diálogo com a arquitetura e as artes plásticas, teria contagiado as letras e começado na colônia precisamente em 1601, graças à publicação da Prosopopeia de Bento Teixeira (em Lisboa), e se encerrado rigorosamente em 1768, quando saem as Obras de Cláudio Manuel da Costa (em Coimbra). Inserido no trânsito cultural da elite letrada, a circular entre a Bahia e São Luís; Coimbra e Lisboa, o movimento com cento e sessenta e sete anos de duração estaria mais ou menos situado entre a chamada "literatura de informação" (cartas, tratados e poemas produzidos nos séculos XVI e XVII) e o Arcadismo, este em tese, emancipador. Considerado como uma corrente exótica, obscura ${ }^{56}$, formalista e serpenteante (e só às vezes divertida), a chamada literatura "barroca" costuma ser protagonizada por dois homens de inegável erudição e envergadura: o padre lusitano Antônio Vieira, que veio para o Estado do Brasil aos seis anos de idade e aqui completou seus estudos religiosos; e o advogado, vigário e poeta Gregório de Matos e Guerra, filho de um poderoso senhor de engenho confortavelmente instalado na província da Bahia.

\footnotetext{
${ }^{56}$ Concebida paralelamente à representação pela imagem (escultura, desenho ou pintura), é um equívoco julgar a poesia do Seiscentos como texto deformado, exagerado ou pautado pelo excesso arbitrário. Para João Adolfo Hansen (1997, p. 184), "No caso dos discursos, o equivalente da deformação plástica da pintura ou da escultura é o acúmulo de ornatos, que produzem a obscuridade ou que efetuam uma representação estilisticamente não-unitária, como misto, ou uma disposição analítica, dividida e subdividida geometricamente como quiasmas, como ocorre nas letras coloniais ditas 'cultistas' e 'conceptistas'."
} 
No que se refere aos poemas atribuídos a Gregório de Matos, desde o início do século XVIII, a começar pela breve biografia do Licenciado Manuel Pereira Rabelo (1999), passou-se a associar o vitupério e a obscenidade, figurados em seus versos, com a vida moralmente desregrada que ele teria levado, supondo-se que fosse um sujeito dado à pândega, à vilania e à libertinagem sexual. "Um notabilíssimo canalha" (ARARIPE JÚNIOR, 1978, p. 285), alardeava um grande adversário do "polemista" Sílvio Romero, nos jornais cariocas de 1893. "Era mais do que um independente - era um desabusado [...] que tudo sacrificou ao desregramento dos seus hábitos e à incontinência da sua língua", disse outro célebre estudioso, três anos depois (LIMA, 1984, pp. 133-134). Incensado como um dos críticos de maior relevo de seu tempo, José Veríssimo estendeu ainda mais o tempo de duração do Setecentos: "Os mesmos poetas do princípio do século XIX, sucessores imediatos dos mineiros e predecessores próximos dos românticos, são ainda e sobretudo seiscentistas, apenas levemente atenuados pelo Arcadismo" (VERÍSSIMO, 1963, p. 5).

Em 1919, Ronald de Carvalho (1968, p. 97) rebaixara, também, a qualidade poética de Manuel Botelho de Oliveira com severos juízos de valor que reverberavam a desqualificação em curso desde o final do século anterior: "As alegorias de mau gosto, as imagens despropositadas, o sentimento postiço de todas as coisas viciam constantemente o lirismo de seus poemas; posto fossem escritos em boa e limpa linguagem, o espírito que os ditava era fraco e vazio, mais amigo da forma que das ideias". Em 1931, Afrânio Peixoto (p. 89) retomou a impressão geral a respeito do "Barroco", e de Gregório em particular, empregando equivocadamente os conceitos de "originalidade" e "plágio". Ele o tomava por "grande poeta colonial, [com a ressalva de que] se era original na sátira violenta, apaixonada, às vezes sem compostura como merecia a impura sociedade colonial, inspirava-se em Gongora e Quevedo, a quem não só imitou, como plagiou". Na opinião de vários comentadores, o "fel" satírico de Gregório guardaria relação com o fato de ter sido preterido ao pleitear cargos da alta administração reinol, mesmo porque os postos eram reservados aos conterrâneos e apaniguados do rei. A costumeira sobreposição do dado moral à persona - voz inventada e modelada artisticamente pelo poeta baiano, em adequação aos assuntos e modalidades poéticas que produziu - explica alguns dos juízos encontrados na antologia que Manuel Bandeira publicou em 1946: “[...] esse inimigo dos mulatos escandalizava a 
toda a gente pelos seus amores com mulatas da mais baixa classe; censurava os bajuladores, mas bajulava também; não tinha escrúpulos em plagiar Gôngora e Quevedo" (BANDEIRA, 2011, p. 12).

Em diversas ocasiões, ainda quando a intenção dos antologistas talvez fosse elogiar o poeta, recaíam em lugares-comuns a ecoar o biografismo moralista. Mencioneme, por exemplo, o manual de Nelson Werneck Sodré (1976, p. 85) - para quem o rumor em torno do nome Gregório de Matos superava a qualidade da obra: "O simples fato de sua obra servir de motivo a tantas controvérsias e despertar ainda tão grande interesse para a pesquisa, apesar de seus fracos atrativos, assinala aquela singularidade". Malgrado fosse um dos primeiros a ressaltar a existência de numerosos "apógrafos", no conjunto da volumosa obra atribuída ao poeta baiano, Péricles Eugênio da Silva Ramos (1977, p. 41) reproduzia a ideia de que “O mérito principal que a crítica descortina em Gregório de Matos é haver ele dotado sua obra de violento sopro de vida, quando a poesia barroca, em geral, era artificiosa e fria".

Como mostra a extensa biografia publicada por João Lúcio de Azevedo em 1918 (2008), a trajetória de Antônio Vieira é igualmente peculiar. Jesuíta de alta patente, atuou nas regiões Norte e Nordeste do Brasil, em prol da catequese indígena, na "defesa" dos seus direitos, "simpático" que foi aos nativos. De volta a Portugal, como conselheiro do rei, foi preso por dois anos e teve de se reportar à Cúria Romana por defender o regresso dos judeus ao reino, como forma de reequilibrar as contas e estimular os melhores negócios por lá. Quase sempre o padre contou a adesão prévia de seus leitores, considerado como um homem de fé e vida regrada, empenhado na dilatação do espírito católico e a expansão dos negócios da sagrada Coroa. Em Vieira, a dimensão temporal e a espiritual se amalgamaram em adesão e coerência com os propósitos da Igreja e do Reino: céu e cetro à distância conveniente dos homens da colônia. A volumosa correspondência do jesuíta frequentemente foi/é interpretada de modo apressado e equivocado, como se se tratasse de produto espontâneo de um sujeito espiritualmente contagiado pela glória de Deus e absorvido pelas tarefas missionárias, deslumbrado com as oportunidades propiciadas pela expansão da Ordem. Graças a Alcir Pécora, passamos a saber que as cartas cumpriam papel determinante na atuação dos noviços, irmãos e padres da Companhia de Jesus, espalhados nos vastos domínios do Reino de Portugal: "Desde os anos de noviciado até o exercício dos 
principais cargos de governo, passando naturalmente pelos ministérios e missões, tudo é lugar onde a arte epistolar encontra funções bem definidas e relevantes a cumprir" (PÉCORA, 2001, p. 26). De modo análogo às regras que orientavam a escrita em versos, a composição de cartas seguia expedientes da Ars Dictaminis - uma das vertentes da Arte Retórica que remonta ao final da Idade Média. ${ }^{57}$

Afora os nomes mais frequentes em exames vestibulares (Gregório e Vieira), restariam os autores e obras de que se ouve falar, mas que hoje praticamente não se leem, como Bento Teixeira, Manuel Botelho de Oliveira, Frei de Itaparica, Eusébio Matos, Padre Antônio de Sá etc. Para isso também contribuem as sentenças depreciativas, reiteradas de tempos em tempos por uma parcela de críticos que se supõe autorizada a fazê-lo, fiel a uma tradição orientada pelo que se entendia como "obscurantismo", "clareza" e "nacionalismo", desde a metade do século XIX. Manuel Bandeira soa taxativo ao afirmar que a Prosopopeia "Nenhum valor literário apresenta, quer pelo conteúdo, mera sucessão de lisonjas bombásticas ao 'sublime Jorge' [...], quer pela forma, canhestro decalque das diç̧ões camonianas" (BANDEIRA, 2011, p. 10). Como ele pressupõe o menor quilate estético do "Barroco", esforça-se por subestimar autores e textos produzidos durante o Setecentos. Para ele, Frei Manuel de Santa Maria Itaparica foi "um fraco poeta" que, na Descrição da Ilha de Itaparica, orientava-se "pelo sentimento nativista, que faz lembrar Botelho de Oliveira e sua Ilha da Maré" (Idem, ibidem, p. 18). Nas observações aligeiradas do poeta/crítico, persistem as concepções idealistas e anacrônicas de "originalidade" versus "plágio", que norteavam os autores de manuais literários desde o Oitocentos, no Brasil.

Enquanto vigorou o sistema colonial luso-brasileiro, até meados do século XVIII, éramos homens de origem (ou mentalidade) portuguesa, orientação católica e calcados nos privilégios aportados de além-mar. Vivia-se a oscilar entre os braços da Administração reinol, fincados nas vilas daqui, e os longos tentáculos do Império sediado em Lisboa, tudo em meio a uma aparelhadíssima e morosa burocracia. No que diz respeito ao Arcadismo, aprendemos superficialmente que ele também se poderia chamar Neoclassicismo, pois retomava os modelos greco-latinos da Antiguidade,

\footnotetext{
${ }^{57}$ Por exemplo, nas instruções aos membros da Companhia de Jesus, Inácio de Loyola recomendava que a "[...] [carta] principal seja [fosse] escrita uma vez e depois reescrita, com correções, 'fazendo de conta que todos a hão de ver'. Isto inscreve, explicitamente, no próprio ato da escrita da carta a consciência do seu efeito nos ânimos dos leitores virtuais" (PÉCORA, 2001, p. 30).
} 
considerados exemplares, e contava com um grupo de poetas mineiros "subversivos" antes do tempo, ora nomeados como nacionalistas, nativistas ou antilusitanos. Essa visão de homens ilustrados, e supostamente contrários aos desígnios da Coroa portuguesa, colabora no equívoco de que se sentissem assim e que procedessem exatamente desse modo; de que encarnassem o primeiro espírito de revolta "nacional" - o que os diferenciaria ideológica e esteticamente dos homens letrados que vieram antes. Esquece-se que, em sua maioria, esses homens eram ideólogos republicanos que mantinham escravos, mas versejavam sobre a liberdade; súditos reinóis que, pertencentes à elite e fiéis às convenções culturais e sociais, versavam sobre o amor; cidadãos de posses acostumados à cidade que representavam o penhasco, a amada idealizada (ou a donzela supostamente "pré-romântica"), a ovelha, a árvore, o cajado, o arado e a cabra. Procura-se explicar o bucolismo como cenário ideal para enquadrar uma linguagem mais "reta", "harmoniosa" e "singela", contrapondo-se o verso teoricamente "plano" ou "linear" dos árcades aos arabescos e borrões setecentistas. Isso tudo parcialmente explicado pelo fato de Portugal ainda não ter sido alvo das reformas radicais atribuídas a Sebastião José de Carvalho e Melo, braço direito do rei Dom José I (1750-1777). Ou seja, a linguagem pré-definida como "cifrada", "difícil", "obscura", "artificial", "exagerada", "grandiloquente" e "datada" dos "barrocos", permitiria contrastá-la com a expressão dita "clara", "simples", "verdadeira" e "natural" dos árcades, conforme as conhecidas fórmulas irradiadas em diversos manuais - não exclusivamente os escolares. Um dos primeiros a relativizar essa concepção foi Afrânio Coutinho (1983, p. 89), ao recuar o emprego da palavra "Barroco":

[...] o primeiro uso da palavra [Barroco] remonta a Montaigne (Essais, I, cap. 25), que a empregou ao lado de "baralipton", para ironizar a escolástica. Nos séculos XVI e XVII, o epíteto significava um modo de raciocínio que confundia o falso e o verdadeiro, uma argumentação estranha e viciosa, evasiva e fugidia, que subvertia as regras do pensamento. Originalmente, portanto, é negativo, pejorativo, sinônimo de bizarro, extravagante, artificial, ampuloso, monstruoso, visando a designar, menoscabando, a arte seiscentista, interpretada dessa maneira, como forma de decadência da arte renascentista ou clássica.

Essa fixação espaço-temporal e estilística do "Barroco brasileiro" - supostamente iniciado por uma obra a que quase todos se referem, mas que poucos conhecem (Prosopopeia), e o fato de os autores serem confrontados com os versos mais "fáceis" e menos "herméticos" dos poetas árcades (Obras), favoreceu a sedimentação de lugares- 
comuns disseminados na absoluta maioria dos materiais de cunho didático. Figuras relevantes de nossa intelectualidade se referiram a uma parcela dos escritores com indisfarçável reserva, destinando poucas linhas à sua produção em versos, frequentemente com o fito de descaracterizá-la e promover outros autores e correntes em seu lugar - especialmente os poetas adeptos da estética neoclássica.

Vulgaridade e discrição orientavam os manuais de poesia desde o século XVII. Em 1633, Manuel Pires de Almeida afirmava no seu Poesia e Pintura ou Pintura e Poesia que a pintura "[...] deleita a doutos e ignorantes, o mesmo obra em ambos a poesia, porque os doutos se recreiam com a boa invenção e sua alegoria, e os ignorantes com as cadências do verso" (MUHANA, 2002, p. 72). Cento e treze anos depois, o iluminado e oratoriano Luís Antônio Verney ressaltava a improcedência de se estudar os autores do século XVII. Na sétima carta (dentre as dezesseis que compunham o Verdadeiro método de estudar), ele rechaçava o tratado de Baltasar Gracián, de 1642 (Arte de ingenio, Tratado de la agudeza), e tratava a Poética em acordo com os preceitos da Antiguidade greco-latina, especialmente a "veracidade" $58:$ "[...] um conceito que não é justo, nem fundado sobre a natureza das coisas, não pode ser belo; porque o fundamento de todo conceito engenhoso, é a verdade" (VERNEY, 1746, p. 219). Em 1850, Francisco Adolfo Varnhagen (1946, p. 23) advertia os leitores quanto aos traços patológicos que contaminariam a poesia licenciosa de Gregório de Matos, em seu Florilégio da poesia brasileira, publicado em Lisboa. Tinha início uma autêntica sanha moralista em torno do "homem" Gregório, o que teria comprometido a qualidade de seus versos: "Como de Quevedo, o estilo [de Gregório] é cortado e desigual: a par de um belo conceito, traz Matos uma sandice, um disparate, ou uma indecência. Sua imaginação era talvez viva, mas descuidada". Embora recendesse ao biografismo mais simplório, a tese de Varnhagen conquistou adeptos durante muito tempo. Confundiase a pessoa com as personas poéticas que figurava decorosamente ${ }^{59}$, ou seja, em acordo com os temas, gêneros e estilos previamente escolhidos ao compor versos. Um século

\footnotetext{
58 “As categorias neoclássicas de 'verdade', 'racionalidade', 'naturalidade' e 'clareza' dessa crítica foram apropriadas nas histórias literárias do século XIX, que constituíram o cânone das literaturas nacionais em Portugal e no Brasil" (HANSEN, 2002, p. 24).

59 No século XV, o italiano Leon Battista Alberti (2014, p. 111) reverberava um dos ensinamentos da Antiguidade: "É preciso [...] que todas as coisas tenham curso de acordo com a dignidade própria. Não seria conveniente vestir Vênus ou Minerva com um grosseiro manto de lã, como igualdade não o seria vestir Marte ou Júpiter com roupa de mulher".
} 
depois, quando "apresentava" a poesia brasileira a um público virtualmente maior, Manuel Bandeira decretou que: "[Gregório de Matos] Não foi um grande poeta, mas era uma personalidade forte, a primeira que assim se afirmava no Brasil, onde a sua posição corresponde proximamente à de Juan de Cavíades, no Peru". A depreciação de outros poetas era ainda mais evidente: "Ao lado dele mal se pode lembrar o nome de Manuel Botelho de Oliveira, autor de um medíocre poema descritivo intitulado Ilha da Maré, cujo único mérito está em inaugurar o louvor do país em nossa poesia" (BANDEIRA, 2011, pp. 14-15). Por sua vez, Antonio Candido (1997, p. 24) se referia a Manuel Botelho de Oliveira como homem detentor de um "espírito devoto e cortesão" e "escritor de certo interesse, exemplo típico do falseamento a que chegou o espírito barroco nos seus aspectos menores, quando a argúcia virou pedantismo e a sutileza um mero exibicionismo, dando a impressão de que a palavra rodava em falso, à procura de nada".

O que a crítica predecessora enxergou como exagero e deficiência em Botelho de Oliveira - resultado de uma poética contorcionista, artificial, falseada etc - foi percebido por Ivan Teixeira (2005, p. 12) como qualidade estética condizente com um homem atento às preceptivas poéticas em vigor no momento histórico em que viveu. Obedecendo ao decoro poético, os versos de Música do parnaso se inscreviam nos gêneros adequados aos temas de que o poeta tratava. Para o pesquisador, deveríamos entender a poesia: "[...] como evento cultural, que partilha de discursos sociais específicos, com normas próprias de invenção, de escritura e de circulação" Isso permitiria "recompor, ainda que parcialmente, o sistema de referências segundo o qual o artista escrevia, sem o que se torna difícil sustentar uma visão histórica do fenômeno poético".

\section{Barroquismo?}

Os manuais escolares também sugerem que determinadas formas de representação artística, encontradas na Europa e na Colônia Brasil durante os séculos XVII e XVIII, espraiaram-se em alguns gêneros literários. A poesia dita "Barroca" dialogava com as construções imponentes dos edifícios coloniais, em cornijas e colunas retorcidas das igrejas, nas pinturas sombrias dos palácios, a reforçar a vida dicotômica 
de padres e poetas, "cindidos" entre os prazeres mundanos e as consolações celestiais. ${ }^{60}$ Provavelmente inspirados pelos tratados sobre história da arte de Heinrich Wölfflin ${ }^{61} \mathrm{e}$ de Aloïs Rieg|62, o fato é que nesses manuais de literatura o "Barroco" se resume a breves listagens de características que visam a totalizar ${ }^{63}$ as qualidades cardeais $\mathrm{e}$ supostos vícios do movimento, dentre os quais a reiterada noção de "Pictórico", "um dos conceitos mais importantes para a história da arte" (1996, p. 39). Apesar da relevância do termo, segundo o historiador, definir essa categoria interpretativa consistia em uma tarefa das mais simples: “Basta, primeiramente, dizer: 'pictórico' é aquilo que faz um quadro, o que, sem que seja preciso acrescentar coisa alguma, oferece um modelo ao pintor" (Idem, pp. 39-40). Wölfflin reforçava o contraste do "Barroco" com a corrente estética que o precedera: "O estilo antigo pensava de modo linear, sendo a sua aspiração o belo movimento e a harmonia de linhas. O estilo pictórico pensa em massas: luz e sombra são seus elementos" (Idem, p. 41). Quer dizer, a retidão se contrapunha à sinuosidade; a clareza à ambiguidade; a reta à aresta. As premissas em que Wölfflin se baseava nortearam boa parte dos capítulos sobre "literatura barroca brasileira". Veja-se o caso de Domício Proença Filho (1983, p. 142) que, em Estilos de época na literatura, de 1967, reproduziu quase literalmente os preceitos do historiador alemão, ao construir tabelas comparativas entre o Renascimento e o "Barroco":

\footnotetext{
${ }^{60} \mathrm{Na}$ Introdução à literatura brasileira, de Afrânio Coutinho, lê-se que o "Barroco" seria uma "arte que exprime uma época de crise e luta, incerteza e instabilidade, inquietude e tormento, desequilíbrio e tensão, em que o homem deixou de ser o centro da Terra, e a Terra o centro do universo" (COUTINHO, 1983, p. 120).

${ }^{61}$ Refiro-me a: Conceitos fundamentais da História da Arte: o problema da evolução dos estilos na arte mais recente (1996) e Renascença e Barroco: estudo sobre a essência do estilo barroco e sua origem na Itália (2010).

62 “[...] o extraordinário que representa a arte barroca, nós não o compreendemos; ele não nos convence, ele nos parece contraditório, falso, e é por isso que o consideramos estranho. Na Antiguidade e na Renascença, o extraordinário nos comove; no Barroco ele nos inspira um sentimento de rejeição, de incômodo, como uma coisa obscura e desprazerosa" (RIEGL, 1993, pp. 38-39).

63 Joaci Pereira Furtado (1997, p. 31) observa que: “Uma interpretação é plausível tanto quanto evite pretensões totalizantes - ou melhor, avizinha-se da totalidade sem contudo esmagar na obra o espaço multifário para outras aproximações. Visto em sua condição peculiar, a partir da perspectiva não menos singular do leitor, o texto necessita ser re-conhecido [sic] primeiramente em sua temporalidade, distante do universo onde se concretiza a leitura extemporânea".
} 


\begin{tabular}{|l|l|}
\hline \multicolumn{1}{|c|}{ Renascimento } & \multicolumn{1}{|c|}{ Barroco } \\
\hline $\begin{array}{l}\text { 1. Linear - caracterização centrada em limites } \\
\text { claros e precisos; }\end{array}$ & $\begin{array}{l}\text { 1. Pictórica - caracterização desviada dos limites } \\
\text { do objeto e centrada na acumulação de } \\
\text { elementos; }\end{array}$ \\
\hline $\begin{array}{l}\text { 2. Composta em superfície - encadeamento de } \\
\text { formas sobre um mesmo plano; }\end{array}$ & $\begin{array}{l}\text { 2. Composta em profundidade - a percepção } \\
\text { visual envolve os elementos mais próximos o os } \\
\text { mais distantes; }\end{array}$ \\
\hline 3. Partes coordenadas de igual valor; & \begin{tabular}{l} 
3. Partes subordinadas a um conjunto; \\
\hline 4. Fechada - limitada em si mesma;
\end{tabular} \\
\hline 5. Claridade absoluta. & 4. Claridade relativa. \\
\hline
\end{tabular}

A forma planificada da tabela induz ao esquematismo terminológico que aproxima o "Barroco" da caricatura artificial. O livro de Proença Filho não foi o primeiro, tampouco o último a abordar o período nesses termos e de modo tão sumário. Disposto na página como matéria de forma e teor didático, esquemas similares irradiaram-se em manuais de literatura, voltados não exclusivamente para o Ensino Médio. A cisão entre o estilo clássico e o setecentista, como sugeriam Wölfflin e Riegl, não cabe em fórmulas tão estreitas. A descontinuidade temporal vincula-se ao método idealizado e teleológico de resumir autores, obras e eventos (nem sempre correlacionados), desconsiderando a sobreposição de mentalidades e representações estéticas em um mesmo período histórico: "A morfologia lineariza os estilos artísticos como unidades consecutivas sobre o eixo de um contínuo temporal, 'clássico' antes, 'barroco' depois, não admitindo a coexistência historicamente observável de múltiplos estilos" (HANSEN, 2006, p. 17).

A oposição entre "classicismo" e "barroquismo" também é levada em conta, quando se pesquisa o Arcadismo. Em 1959, Antonio Candido (2000, p. 49) supusera que “O Arcadismo é, pois, consciência da integração: de ajustamento a uma ordem natural, social e literária, decorrendo disso a estética da imitação, por meio da qual o espírito reproduz as formas naturais". A seu turno, Afrânio Coutinho propunha-se a incorporar os portugueses (de Pero Vaz de Caminha em diante), uma vez que eles teriam produzido uma literatura "no" Brasil, sujeita à influência da atmosfera local, resultando em uma produção híbrida. Se o "Barroco" não era considerado por Antonio Candido como um movimento brasileiro e de caráter sistêmico, provavelmente dadas as rasas condições culturais e a quase inexistente circulação de impressos à época de Gregório de Matos e Antônio Vieira, para Coutinho, a corrente poderia ser compreendida como uma "evolução" do Classicismo - o que justificaria o caráter luso-brasileiro das obras, do 
ponto de vista cultural e social. ${ }^{64}$ Repare-se que os termos "rebuscamento", "barroquismo" e similares são apresentados com sinal negativo em diversas Histórias da literatura brasileira. Porém, os antologistas sabem (ou deveriam sabê-lo) que o rótulo "Barroco" foi cunhado no final do século XIX e aplicado a um conjunto de obras de tempos distantes e características sobremodo distintas, sob o fórceps de um didatismo impreciso. Há que se propor outros recortes e categorias, tendo em vista uma maior aproximação com o contexto histórico e cultural em que as representações artísticas e textuais tiveram lugar. Como defende João Adolfo Hansen (2006, p. 16),

O "barroco" nunca existiu historicamente no tempo classificado pelo termo, pois "barroco" é Heinrich Wölfflin e os usos de Wölfflin. Melhor dizendo, a noção só passou a existir formulada positivamente, em 1888, na obra admirável de Wölfflin, Renascimento e Barroco, como categoria neokantiana apriorística em um esquema ou morfologia de cinco pares de oposições de "clássico" e "barroco" aplicados dedutivamente para apresentar alguns estilos de algumas artes plásticas dos séculos XVI e XVII. Antes de Wöllflin, em 1855, indiciando o crescente interesse pela noção, Jacob Burckhardt havia proposto que o Barockstyl era um "dialeto selvagem" da linguagem renascentista. Riegl falou de "tátil" e "visual".

\section{Arcádia}

Os supostos "vícios" ou "defeitos", virtualmente encontráveis nos textos produzidos anteriormente ao período árcade, ajudaram a cristalizar a imagem do texto "barroco" como artigo local, mesmo porque produzido no Brasil, mas desprovido de "nativismo"65. A isso se somaria a hipótese de soar hermético e ser de difícil compreensão, inclusive no ambiente universitário, em nossos dias ${ }^{66}$. Ainda topamos

\footnotetext{
64 Em 1970, Alfredo Bosi (2004, p. 32) retomou a caracterização sugerida por Wölfflin e reiterou a comparação do movimento com o Arcadismo, em aparente prejuízo do primeiro: "O rebuscamento em abstrato é, sem dúvida, o lado estéril do Barroco e o seu estiolar-se em barroquismo. Contra essa deterioração do espírito criador iriam reagir em Portugal e Espanha, nos meados do século XVIII (e meio século antes, na Itália) os poetas árcades, já imbuídos de neoquinhentismo e do 'bom gosto' francês".

65 “O resgate desses prenúncios nativistas pela história literária compõe as expressões sucessivas e progressivas da natureza física e humana do país, fazendo da literatura um instrumento de formação da jovem nação. Nessa história, o telos nacionalista determina os critérios de definição do que seja o evento válido de se representado e a qualidade estética positiva da arte que o representa, fazendo selecionar aqui e ali, nas obras coloniais, exemplos do ideal pré-formado pela retrospecção do intérprete, que transforma os autores coloniais 'barrocos' em protonacionalistas" (HANSEN, 2002, p. 25).

${ }^{66}$ Ao descrever as academias literárias que surgiram no primeiro quarto do século XVIII, Alexei Bueno (2007, p. 35) sugere que: “A poesia criada nessas agremiações, algumas poucas vezes brilhante, em muitas ocasiões rasteira até o ridículo, usando e abusando de todos os recursos possíveis do barroco em decadência, como poemas tetra ou pentalíngues, cantões, poemas diacrósticos ou até mesmo tetracrósticos, labirintos, ecos, versos com consoantes interrompidas, fora um grande arsenal de recursos
} 
com estudiosos que condenam a escrita de poetas e prosadores do Seiscentos, recorrendo a rótulos pseudobiográficos e a etiquetas de matiz estilística. Esses rótulos não se limitam aos manuais editados no Brasil; mas foram reproduzidos em estudos de prestígio, a exemplo do opúsculo de Roger Bastide, Études de Littérature Brésilienne, publicado na França em 1954. As considerações do célebre professor francês, com longa passagem pela Universidade de São Paulo, reverberam o que se dizia sobre os poetas seiscentistas desde o final do século XIX, por aqui: “Acusou-se Gregório de Matos que ele foi, ainda em vida, um plagiador, e os críticos literários retomam essa crítica de tempos em tempos" (BASTIDE, 1954, p. 3).

Quando Heinrich Wölfflin e Aloïs Riegl foram eleitos como paradigmas de uma descrição generalista e estanque do "Barroco", aderiu-se aos pressupostos da Escola de Viena, que se centrava nos estudos a respeito da "visibilidade" em detrimento da análise dos procedimentos artísticos, com base na "teoria da visibilidade pura [que] deu origem a [...] Escola de Viena" (BARROS, 2011, p. 67). Dentre o rol de elementos minimalistas e redutores, que oferecem uma espécie de metonímia da arte "barroca", destaca-se o adjetivo "pictórico", encontrável em numerosos manuais de literatura, voltados tanto para o ensino médio quanto para o superior. Em Conceitos fundamentais da história da arte, Heirinch Wölfflin (1996, p. 27) supunha que: "podemos estabelecer assim a diferença entre os dois estilos: a visão linear distingue nitidamente uma forma de outra, enquanto a visão pictórica, ao contrário, busca aquele movimento que ultrapassa o conjunto dos objetos". Nas notas para um curso sobre História da Arte, publicado em 1907, Aloïs Riegl afirmava que: “O período da Contrarreforma severa não foi favorável à arte figurativa ${ }^{67}$. $O$ conflito interior só deve ser revelado materialmente, e não através da forma psíquica das figuras humanas. Desde que elas apareceram, falta-lhes a profundidade espiritual de Michelangelo (RIEGL, 1993, p. 159).

\footnotetext{
visuais que humilharia muitos dos nossos poetas concretos, chegou até nós parte em antologias editadas na Metrópole, parte em diversos códices manuscritos. É, no geral, poesia morta e enterrada, último fruto de um artificialismo que em breve seria vencido por outro, tão ou mais falso, o Arcadismo".

${ }^{67}$ Em Da pintura antiga, Francisco de Holanda (1984a, p. 20-21) assim definia a pintura: "É esta arte copioso tesouro de infinitas imagens e figuras elegantes, o qual não se poderá nunca acabar nem diminuir. É honor das artes, e uma mostra do interior do homem, semelhante à delicadeza da alma, e não à do corpo. É proporção das formas perfeitas e imperfeitas, e espelho em que reverbera e se vê a obra do mundo. É história de todo o tempo. É mantimento e pasto do entendimento e recreação do grão cuidado. É verdadeiro fingimento e arrazoado. É alma do espírito e da mente. É corpo da memória"
} 
Quando os historiadores tentam conceituar, descrever e delimitar o Arcadismo brasileiro, costumam não mencionar o qualificador em questão ("pictórico"), a despeito de defenderem, com aparente convicção, a tese de que os poetas ilustrados do período cumpriam rigorosamente as lições de Horácio, autor da Arte Poética. Eis um fenômeno curioso, já que o método de Horácio ${ }^{68}$ consistia em aproximar a composição poética da pintura de um quadro, prevendo a eleição de um tema, a obediência à sua proporção e medidas, bem como a adequação de suas partes em função de um gênero escolhido, sem perder de vista determinado público a que a obra (fruto de rascunho e desenho) se destinasse: "Vocês, que escrevem, tomem um tema adequado a suas forças; ponderem longamente o que seus ombros se recusem a carregar, o que aguentem. A quem domina o assunto escolhido não faltará eloquência nem lúcida ordenação" (HORÁCIO, 2005, p. 56). ${ }^{69}$ De acordo com o tratadista romano, era justamente o apelo à imagem ${ }^{70}$ que permitia as analogias (não a equivalência) entre uma arte e outra. Portanto, aceita a hipótese de que os árcades luso-brasileiros tinham os preceitos horacianos em alta conta, não há sentido em desprezar o forte apelo imagético sugerido pelos versos de Cláudio, Basílio, Durão, Tomás, Alvarenga etc, como se a categoria "pictórico" estivesse unicamente reservada à estética "predecessora", atrelada ao caráter "alegórico" do texto "Barroco".

A questão se complica ao consideramos que, muito antes dos árcades, Bento Teixeira e Manuel Botelho de Oliveira seguiram fielmente as preceptivas de Horácio. Em 1999, José Aderaldo Castello (1999, pp. 72-73) entrevia “[...] na obra de Bento Teixeira - o poemeto Prosopopeia (1601) - uma referência à Arte Poética de Horácio e crítica ao estilo mitológico, não obstante a tentativa que ele mesmo fez de transplantação do universo mitológico para a paisagem americana". O historiador relativizava a costumeira

\footnotetext{
68 Plutarco "achava que fora Simônides o primeiro a comparar os métodos da poesia com os da pintura, tendo sua teoria sido posteriormente resumida por Horácio na célebre frase ut pictura poesis. Plutarco diz que 'Simônides chamava a pintura de poesia silenciosa e a poesia, de pintura que fala, pois as ações são pintadas enquanto ocorrem, já as palavras as descrevem depois de terem acontecido'." (YATES, 2013, p. 48).

${ }^{69}$ No século XVIII, Denis Diderot (2013, p. 39) assegurava: “Sem sombra de dúvida, um pintor mostra-se em sua obra tanto ou mais que um escritor na sua".

70 Memória e imagem estavam interligadas desde a Antiguidade e eram decisivas no ofício de escrever e pintar. No século XVI, o português Francisco de Holanda (1948b, p. 128) defendia que "se pudera ser estar o mesmo desenhador só, sem ninguém, e ter na fantasia e memória a pessoa que há-de por em obra e pintar, crede que muito melhor seria que tê-la diante dos olhos visíveis se a visse com os invisíveis, quanto mais estar contentando a quantos indiscretos há numa corte e tê-los todos presentes".
} 
distinção radical entre uma estética e outra. Afinal, vale para a poesia em geral a hipótese horaciana de que "As ações ou se representam em cena ou se narram. Quando recebidas pelos ouvidos, causam emoção mais fraca que, quando apresentadas à fidelidade dos olhos, o espectador mesmo as testemunha" (HORÁCIO, 2005, p. 60). Parece não haver dúvida de que os poetas seiscentistas seguiam com rigor os preceitos de poética que circulavam em manuais, nas cortes e salões de gente poderosa e abastada. Veja-se esse relevante exemplo. Ao resgatar o Tractatio de Poësi et Pictura ethnica et fabulosa collata cum vera, honesta e sacra, escrito em 1595 pelo jesuíta Antonio Possevino, Hansen (1997, p. 179) percebeu que o padre italiano reiterava os ensinamentos de Horácio:

Possevino afirma que a poesia, arte de imitação como a pintura, é imagem: assim como o pincel imita os topoi narrativos das ecfrases de autoridades, também a pena deve imitar o pincel, produzindo metáforas visualizantes de efeitos maravilhosos, simultaneamente adequados à utilidade e ao prazer. Lembra, neste sentido, que os gregos chamavam de graphein o verbo relativo à faculdade do desenho, significando com ele tanto figurado pela mão na forma de letras e linhas, quanto o expresso pela voz em palavras. Possevino entende "desenho" como o resultado exterior do desenho interno ou conceito.

Em obediência aos preceitos encontrados nesses e em diversos outros tratados, redigidos antes e durante o Setecentos, subentende-se que os letrados daquele tempo produziam versos a partir de preceptivas, dando continuidade ao que já acontecia com os poetas "barrocos". Aceita a concepção de que se tratava de uma grafia de caráter imagético, há que se considerar que ela não se restringiria a um movimento em particular, posto que também estava no horizonte cultural dos poetas árcades, cultivadores de Horácio. A caracterização do estilo pictórico não é tão simples, como pretendem alguns manuais de literatura brasileira:

O estilo linear é um estilo da discriminação visualizada plasticamente. 0 contorno nítido e firme dos corpos suscita no espectador uma sensação de segurança tão forte, que ele acredita poder tocá-los com os dedos, e todas as sombras modeladoras adaptam-se de tal modo à forma, que o sentido do tato é imediatamente estimulado. Representação e objeto são, por assim dizer, idênticos. Ao contrário, o estilo pictórico libertou-se, de certa maneira, do objeto tal como ele é. Para este estilo, já não existe o contorno ininterrupto, e as superfícies tangíveis são dissolvidas (WÖLFFLIN, 1996, pp. 28-29).

A discussão em torno dos usos do "pictórico" pelos manuais brasileiros de literatura, poderia ir muito longe. Embora "pictórico" seja termo corrente em nosso 
vocabulário, ele parece ter ficado adstrito à descrição reducionista daquele "problemático" movimento, em contraposição à "linearidade" dos clássicos e à "clareza" dos árcades; em oposição aos "ângulos retos" dos clássicos e ao "bucolismo" singelo dos árcades; em contraste com o modo temperado dos clássicos e à linguagem mais "sóbria" e "econômica" dos árcades etc. O problema não se restringe à nomenclatura, mas ao método que acompanha o uso anacrônico de rótulos.

Ao adotar a terminologia de Wölfflin e Riegl para caracterizar o chamado "Barroco" brasileiro, o vocábulo "Pictórico" foi alçado de adjetivo a categoria estética, e passou a reforçar a afixação de todos os gêneros textuais que se produziram entre 1601 e 1768 - cartas, poemas, sermões, tratados e congêneres - como manifestações "artificiais" e "frias", provenientes de uma mesma e opaca forja discursiva. Ressalvados os fatores, condicionantes históricos e aspectos culturais de cada tempo, o elemento pictórico também preside a descrição da paisagem e dos índios na Carta de Caminha; figura os versos em tupi de José de Anchieta e enforma os sermões alegóricos de Vieira. Condensa-se nos retratos satíricos feitos por Gregório de Matos e Tomás Antônio Gonzaga (Cartas chilenas); persiste nas descrições de heróis - tão ou mais "artificiais" a protagonizar os poemas épicos de Santa Rita Durão e Basílio da Gama. 


\section{Referências}

ALBERTI, Leon Battista. Da pintura. 4 ed. Tradução: Antonio da Silveira Mendonça. Campinas (SP): Editora da Unicamp, 2014.

ARARIPE JÚNIOR, Tristão de Alencar. Teoria, crítica e história literária. Rio de Janeiro: Livros Técnicos e Científicos; São Paulo: Edusp, 1978. [Seleção e Apresentação de Alfredo Bosi]

AZEVEDO, João Lúcio de. História de Antônio Vieira. Tomo I. São Paulo: Alameda Editorial, 2008.

BANDEIRA, Manuel. Apresentação da poesia brasileira (seguida de uma antologia). São Paulo: Cosac Naify, 2011.

BARROS, José D'Assunção. Heinrich Wölfflin e sua contribuição para a teoria da visibilidade pura. Existência e Arte - Revista Eletrônica do Grupo PET. Universidade Federal de São João Del-Rei, Ano VII, n. VI, 2011, pp. 65-81.

BASTIDE, Roger. Études de Littérature Brésilienne. Institut des Hautes Études de L'Amérique Latine (Centre de Documentation Universitaire). Sorbone, Paris, 1954.

BOSI, Alfredo. História concisa da literatura brasileira. 42. ed. São Paulo: Cultrix, 2004.

BUENO, Alexei. Uma história da poesia brasileira. Rio de Janeiro: G. Ermakoff Casa Editorial, 2007.

CANDIDO, Antonio. Iniciação à literatura brasileira (resumo para principiantes). São Paulo: Humanitas, 1997.

Formação da literatura brasileira: momentos decisivos. 6. ed. Belo Horizonte: Editora Itatiaia, 2000.

CARVALHO, Ronald de. Pequena história da literatura brasileira. 13. ed. Rio de Janeiro: F. Briguet \& Cia. Editores, 1968.

CASTELLO, José Aderaldo. A literatura brasileira: origens e unidade (1500-1960). São Paulo: Edusp, 1999.

COUTINHO, Afrânio. Introdução à literatura no Brasil. 11. ed. Rio de Janeiro: Editora Civilização Brasileira, 1983.

DIDEROT, Denis. Ensaios sobre a pintura. 2. ed. Tradução: Enid Abreu. Campinas (SP): Editora da Unicamp, 2013.

FURTADO, Joaci Pereira. Uma república de leitores: história e memória na recepção das Cartas Chilenas (1845-1989). São Paulo: Hucitec, 1997. 
HANSEN, João Adolfo. Ut pictura poesis e verossimilhança: a doutrina do conceito no século XVII colonial. Revista de Crítica Literária Latinoamericana, Año XXIII, n. 45. LimaBerkeley, 1997, pp. 177-191.

Uma introdução. In: PÉCORA, Alcir (org). Poesia Seiscentista: Fênix renascida \& Postilhão de Apolo. São Paulo: Hedra, 2002, pp. 21-71.

84.

Barroco, Neobarroco e outras ruínas. Revista Floema, Ano 11, n. 2, 2006, pp. 15-

HOLANDA, Francisco de. Da pintura antiga. Lisboa: Livros Horizonte, 1984a.

. Do tirar polo natural. Lisboa: Livros Horizonte, 1984b.

HORÁCIO. Arte poética. In: A poética clássica. 12. ed. Tradução: Jaime Bruna. São Paulo: Cultrix, 2005, pp. 53-68.

LIMA, Manuel de Oliveira. Aspectos da literatura colonial. Rio de Janeiro: Francisco Alves; INL, 1984.

MUHANA, Adma. Poesia e pintura ou Pintura e poesia: tratado seiscentista de Manuel Pires de Almeida. São Paulo: Edusp, 2002.

PÉCORA, Alcir. A arte das cartas jesuíticas no Brasil. In: . Máquina de gêneros. São Paulo: Edusp, 2001.

PEIXOTO, Afrânio. Noções de história da literatura brasileira. Rio de Janeiro: Livraria Francisco Alves, 1931.

PROENÇA FILHO, Domício. Estilos de época na literatura (através de textos comentados). 7a ed. São Paulo: Editora Ática, 1983.

RABELO, Manuel Pereira. Vida do excelente poeta lírico, o Doutor Gregório de Matos Guerra. In: MATOS, Gregório de. Obra poética. Vol. Il. 4. ed. Rio de Janeiro: Record, 1999, pp. 1251-1270. [Edição de James Amado]

RAMOS, Péricles Eugênio da Silva. Poesia barroca. São Paulo: Melhoramentos, 1977.

RIEGL, Aloïs. L'origine de l'art baroque à Rome. Tradução (para o francês): Sibylle Muller. Paris: Klincksieck, 1993.

SODRÉ, Nelson Werneck. História da literatura brasileira: seus fundamentos econômicos. 6a ed. Rio de Janeiro: Civilização Brasileira, 1976.

TEIXEIRA, Ivan. A poesia aguda do engenhoso fidalgo Manuel Botelho de Oliveira. In: OLIVEIRA, Manuel Botelho de. Música do Parnaso. Cotia (SP): Ateliê Editorial, 2005, pp. 7-96. 
VARNHAGEN, Francisco Adolfo de. Florilégio da poesia brasileira. Tomo I. Rio de Janeiro: Academia Brasileira de Letras, 1946. [Organização de Afrânio Peixoto]

VERISSIMO, José. História da literatura brasileira. 4. ed. Brasília (DF): Editora da UnB, 1963.

VERNEY, Luís Antônio. Verdadeiro método de estudar. Tomo I. Valensa [Nápoles]: Oficina de Antonio Balle, 1746 - Versão digital disponível em: http://purl.pt/118 - Acesso em 24 de setembro de 2016.

WÖLFFLIN, Heinrich. Renascença e Barroco: estudo sobre a essência do estilo barroco e sua origem na Itália. 3a reimp. Tradução: Mary Amazonas Leite de Barros e Antonio Steffen. São Paulo: Editora Perspectiva, 2010.

Conceitos fundamentais da História da Arte: o problema da evolução dos estilos na arte mais recente. $3^{a}$ ed. Tradução: João Azenha Júnior. São Paulo: Editora WMF Martins Fontes, 1996.

YATES, Frances A. A arte da memória. Tradução: Flavia Bancher. Campinas (SP): Editora da Unicamp, 2013. 


\title{
Hierarquia e Adulação em Antônio Vieira
}

\author{
Quando comprares um escravo hebreu, seis anos ele servirá; \\ mas no sétimo sairá livre, sem nada pagar (Êxodo: 21). ${ }^{71}$ \\ [...] a conversão desses bárbaros jamais se fará pelo amor, mas \\ somente depois de tê-los subjugado pela força das armas e \\ torná-los vassalos do rei nosso senhor (Gaspar Simões). ${ }^{72}$
}

Resumo: Neste artigo, aborda-se a construção do éthos virtuoso de Antônio Vieira, a partir da leitura de sermões e missivas pregadas na década de 1650, pouco antes de sua segunda vinda para o continente americano. A análise enfatiza o Sermão da Primeira Sexta-Feira da Quaresma, pregado na Capela Real de Lisboa em 1651.

Palavras-Chave: Retórica; Sermão; Antônio Vieira.

Abstract: In this article, we analyses the éthos's construction by Antônio Vieira, from the reading of sermons and missives preached in the 1650s, before his second travel to the American continent. This analysis emphasizes Sermão da Primeira Sexta-Feira da Quaresma, preached in the Lisbon Royal Chapel in 1651.

Keywords: Rhetoric; Sermon; Antônio Vieira.

\section{Matéria}

O Cântico dos Cânticos menciona uma rica liteira sustentada por sessenta homens que carregava o Rei Salomão. Lá, e também nos Salmos, vemos o modo como seu pai, Davi, procedera implacavelmente em relação aos inimigos e aduladores ${ }^{73}$. Para além da reafirmação do poder, essas historietas muito interessam porque também ilustram um dos argumentos centrais sustentados por Antônio Vieira no Sermão da Primeira Sexta-Feira da Quaresma, pregado na Capela Real de Lisboa em 1651. Com habilidade, o orador recorre à conduta de Davi e seu filho, em provável analogia com a sucessão dos monarcas portugueses, em particular Dom João IV - que possivelmente

\footnotetext{
${ }^{71}$ Bíblia de Jerusalém, 2015, p. 132.

72 "Carta de Gaspar Simões para o provincial jesuíta, datada de Luanda, 20 de outubro de 1575" (Cf. BOXER, 2007, pp. 94 e 163).

${ }^{73}$ Para intimidar os pecadores e realçar o poder atribuído a Deus, os vícios relativos ao caráter constituem uma das tópicas fundamentais e estruturantes do discurso bíblico. Em Salmos, 12 (11), lê-se: "Socorro, lahweh! Não há mais homem fiel! / A lealdade desapareceu dentre os filhos de Adão! / Cada qual mente ao seu próximo, falando / com lábios fluentes e duplo coração" (BÍBLIA, 2015, p. 873). Nos Provérbios, 11 (3) encontra-se a máxima de que "A integridade guia os homens retos, / e a maldade destrói os traidores" (Idem, ibidem, p. 1036). O Salmo 18 (17), a que se refere Vieira (2015, p. 199) subintitula-se "Te Deum Real", e se atribui a "Davi, servo de lahweh" (BÍBLIA, 2015, p. 877).
} 
assistiu ao sermão ${ }^{74}$, embora começasse a se afastar do Confessor Real, naquele momento. Para além das várias alusões às escrituras, obras da patrística e tratados filosóficos, o discurso também chama atenção pelo modo como foi disposto. Logo à segunda frase, o pregador menciona as faculdades da alma, conforme as definia Santo Agostinho $^{75}$ - uma das auctoritates recorrentes a que Vieira busca e se afilia ${ }^{76}$, com o intuito de reforçar a consistência do argumento, levando em conta o auditório mais homogêneo ${ }^{77}$ e discreto ${ }^{78}$ que o escutaria.

Recorde-se que no ano anterior a essa pregação na Capela Real, eminentemente voltada para o auditório palaciano, o jesuíta fora enviado a Itália, em missão a mando do rei $^{79}$, para desembaraçar questões de natureza diplomática, sem lograr total êxito. Seria razoável supor que Vieira - em meio à murmuração dos olheiros, maquinações de cortesãos e movimentos da Corte -, tivesse composto esse sermão, também, para dar testemunho público de sua fidelidade e sujeição a João IV ${ }^{80}$, e simultaneamente, alertálo sobre os "inimigos internos" ou "aduladores" do reino? Em caso afirmativo, ao

\footnotetext{
${ }^{74}$ [Os] sermões na Capela Real portuguesa (...) eram dirigidos às mais altas autoridades do reino, incluídos o rei e a rainha (PÉCORA, 2008, p. 47).

75 "Deixemos de lado, por enquanto, os demais atos de que a alma está certa de lhe pertencer como propriedade, tratemos agora das três faculdades já antes consideradas: a memória, a inteligência e a vontade" (AGOSTINHO, 2016, p. 330).

${ }^{76}$ É a isto que se chama o conceito predicável, método argumentativo utilizado na oratória sacra do Seiscentos e que se baseava na autoridade do texto sagrado, tomado como "conceito" ou metáfora que o orador desenvolvia, interpretando-o (LEMOS; RAMON, 2015, p. 14).

77 “[...] em matéria de retórica, parece-nos preferível definir o auditório como o conjunto daqueles que o orador quer influenciar com sua argumentação (...) A retórica, tornada exercício escolar, dirige-se a auditórios convencionais e pode, sem inconvenientes, ater-se a visões estereotipadas deles, o que contribuiu, tanto quanto a artificialidade dos temas, para fazê-la degenerar. A argumentação efetiva tem de conceber o auditório presumido tão próximo quanto o possível da realidade" (PERELMAN, 1996, p. 22).

78 "Agudeza, prudência, dissimulação, aparência e honra constituem a discrição. Nas monarquias absolutistas do século XVII, principalmente nas ibéricas, a discrição é padrão nuclear da racionalidade de corte que define o cortesão, proposto para todo o corpo político do Estado como o modelo do uomo universale, o homem universal, como dizia Castiglione no século XVI. Nas práticas de representação, a discrição é categoria intelectual que classifica ou especifica a distinção e a superioridade de ações e palavras, aparecendo figurada no discreto, que é tipo ou personagem dos processos de interlocução. Etimologicamente, o substantivo discreto, como em o discreto, é a forma do particípio passado do verbo discernir" (HANSEN, 2019, p. 104).

79 "O cardeal Armand Richelieu declarou certa vez que nada o havia impressionado tanto como a afirmação de certo espanhol prudente de que o fundamento tríplice do poderio espanhol eram: Mar, Consejo y Roma. Ao império ultramarino (= Mar) e à administração fiel ao rei e à lei (=Consejo, conselho) deve somar-se a ortodoxia católica (= Roma). Só isto tudo junto é Espanha" (HÖFFNER, 1986, p. 93).

80 "A metáfora do 'corpo' é substancializada nos textos neoescolásticos dos séculos XVI e XVII; no caso de Portugal, é apropriada na doutrina do 'pacto de sujeição' do 'corpo místico do Estado' feita por Francisco Suárez em De Legibus, tornando-se um dos fundamentos do direito absoluto e do direito ordinário também no Estado do Brasil, onde regula o exclusivo monopolista e a ação jesuítica (HANSEN, 2019, pp.78-79).
} 
proceder dessa maneira, teria feito da oratória escudo verbal, face aos rumores sobre a queda de seu prestígio e menor influência junto ao rei, como sugerem algumas correspondências e outros documentos daquele período.

Por exemplo, na carta enviada a D. João IV em 28 de fevereiro de 1650, o jesuíta tentara abrir os olhos do rei para dois membros da Companhia de Jesus em missão - um pela falta de caráter; outro, pela incapacidade de guardar segredo das questões do reino. Em relação ao primeiro, "O Padre Nuno da Cunha (...) não trata mais que de adiantar as pretensões de seu irmão e suas, fazendo degrau do serviço de Vossa Majestade sobre o qual põem os pés". Quanto ao segundo, "Manuel Alves Carrilho tem muito bom zelo, mas tudo crê e tudo fala; e sem segredo nem consideração mal se podem obrar negócios que pedem tanta" (VIEIRA, 2014, p. 293). Meses depois, dirigese ao Príncipe Teodósio de Bragança (primogênito de Dom João IV) com missiva remetida em 26 de maio de 1650, onde sugere que, "Como há poucos Antônios Vieiras, há também poucos que amam só por amor; e assim Sua Majestade não deve esperar finezas, senão contentar-se muito de que se queiram vender aqueles que lhe for necessário comprar" (Idem, ibidem, p. 297).

$\mathrm{Na}$ carta de fevereiro, o conselheiro reivindica e encena um de seus papéis junto ao reino: zelar pelas contas e companhias do rei. Na carta de maio, dialoga (ainda que pelo avesso) com o que Maquiavel aconselhava nO Príncipe ${ }^{81}$, sobre a astúcia e violência do governante, com mais de um século de antecedência. Na correspondência a Dom João IV, Vieira reforça o éthos de juiz, súdito fiel e atento às questões do reino, dentro e fora de Portugal. Na carta a Teodósio, alude ao pai do Príncipe e destaca a importância de o rei zelar pelo amor de seu povo, através de gestos caritativos (e não necessariamente honestos).

De modo similar, o Sermão da Primeira Sexta-Feira da Quaresma enaltece a charitas, virtude ainda mais exemplar quando praticada pela autoridade máxima do

\footnotetext{
81 "Porque, avançando os homens sempre por caminhos batidos por outros e procedendo em suas ações por imitação, mas, sem poder seguir à risca a trilha de outrem nem alcançar a virtude daquele que se imita, um homem prudente deve tomar sempre a via trilhada por homens ilustres, que foram exemplos excelentíssimos a serem imitados: e, não sendo possível ombrear-lhes a virtude, que ao menos se deixe algum vislumbre dela; e que se faça como os arqueiros sensatos, os quais, diante de um alvo demasiado distante, e conhecendo até onde vai a potência de seu arco, alçam a mira muito mais alta que o ponto de destino, não para alcançar com suas flechas tanta altura, mas para poder, com o auxílio de tão alta mira, atingir a sua meta" (MAQUIAVEL, 2010, p. 44).
} 
governo temporal, isto é, o rei. Em seguida, Vieira submete todos (também Dom João IV) ao mandamento de que seria preciso "amar os inimigos". Finalmente, divide os inimigos do reino entre os "externos", que porventura não amem o rei, situados para além dos muros do palácio; e os "internos", costumeiramente mais próximos do rei, que fingem amá-lo. Ao distribuir a matéria desse modo, Antônio Vieira recorda que os amigos edificam; os aduladores cobiçam; os súditos fiéis corrigem ações do rei; os inimigos dissimulam a verdade e simulam elogios, já que sua alma é inconsistente e seu caráter inconstante.

Em outro sentido, os aduladores da Corte seriam homens pérfidos que agiriam de modo similar aos hereges, em particular, os gentios ${ }^{82}$ - perspectiva que permitiria evocar muitos outros Sermões de Vieira, a exemplo do Sermão pelo Bom Sucesso das Armas de Portugal contra as de Holanda, pregado em 1640, na Bahia: "A Seita do Herege torpe, e brutal concorda mais com a brutalidade do bárbaro" (VIEIRA, 2015b, p. 80). Isso nos leva a cogitar que a relação dos jesuítas em relação aos índios certamente não era percebida como ambivalente ou contraditória ${ }^{83}$, durante os séculos XVI e XVII. Conforme salienta Alcir Pécora (2005, pp. 89-90):

\begin{abstract}
Visto no interior do corpo místico a que passa a pertencer, o gentio ocupa um lugar hierárquico definido, pelo qual responde jurídica, política, moral e religiosamente. (...) Sem retirar o sentido originalmente injusto da escravidão, Vieira considera que a nova situação vivida pelo gentio, desde que o faça ingressar na religião cristã, é melhor do que a anterior, ignorante de Cristo, ainda que livre. Pois, catolicamente, apenas agora, mesmo cativos, os gentios conheciam a liberdade, que não se define como ausência de subordinação temporal a um senhor, mas como exercício do arbítrio que reconhece e elege para si o bem de Cristo.
\end{abstract}

Salvo engano, haveria cabimento em discutir a construção do éthos virtuoso com que Vieira pretendia justificar a confiança depositada pelo rei. Para isso, o pregador

\footnotetext{
82 Uma das teses recorrentes no documento elaborado entre 1545 e 1563, pelo Concílio de Trento, deixa clara a seletividade com que a graça divina se estenderia aos homens: "Embora tenha ele morrido por todos $(2$ Cor 5,15$)$ não obstante nem todos recebem o benefício da sua morte, mas somente aqueles aos quais é comunicado o merecimento de sua Paixão" (CONCílIO, 1953, p. 10)

83 "Durante séculos, a união entre cruz e coroa foi representada pela instituição da patronagem real - a palavra é esta mesmo, apesar de sua associação com a escravidão no 'Velho Sul' - da Igreja ultramarina por parte das Coroas ibéricas: o Padroado real, em português, e o Patronato (ou Patronazgo) em espanhol. O padroado real português pode ser definido em geral como uma combinação de direitos, privilégios e deveres concedidos pelo papado à Coroa de Portugal na qualidade de patrocinadora das missões católicas e dos estabelecimentos eclesiásticos missioneiros na África, Ásia e Brasil” (BOXER, 2007, p. 98).
} 
mobilizou vasto repertório, pautado pela Teologia, pela Filosofia e pela Política, com o fim de descrever e classificar os membros da corte como amigos ou inimigos do reino. Poder-se-ia afirmar que o pregador descreve uma morfologia da corte e demonstra que o exercício da caridade não compete aos súditos: é virtude maior, reservada ao rei, segundo a lógica embutida na razão de estado que embalou Portugal até o início do século XIX.

\section{Divisão}

Quando examinamos a obra de Antônio Vieira, importa lembrar que seus escritos foram constantemente submetidos à mesa censória do Tribunal do Santo Ofício. É ilustrativo dessa operação o longo período durante o qual enfrentou a Inquisição portuguesa. A questão é instigante, pois também pode se relacionar aos sermões pregados pelo jesuíta. Isso porque os autos do processo movido contra o padre incluíram textos e relatos sobre o contato de Vieira com os heréticos e mesmo a interferência nos negócios da Coroa. Adma Muhana (2008, p. 14) atenta para a circunstância de que:

Não suscitando propriamente questões interpretativas, a principal questão que essa correspondência coloca para a compreensão do Processo, a meu ver, é a da sua finalidade. Declarações datadas de 1663, denúncias de 1649 e 1656 e outros documentos só serão agregadas ao Processo a partir da prisão de Vieira, em 1665, quando a disposição de condená-lo faz com que todos os indícios antecedentes sejam agrupados para compor as provas.

Seria possível detectar tais interferências, murmuradas entre os cortesãos, no Sermão da Primeira Sexta-Feira da Quaresma? Consideremos os pressupostos, métodos e objetivos do orador. 0 decoro ${ }^{84}$ se estabelece pela menção, nas primeiras linhas, aos livros do Antigo Testamento (Cânticos e Salmos), que relembram o preceito de fazer o bem aos inimigos ${ }^{85}$. Ao desenvolver a exposição, respaldada por inúmeros exemplos

\footnotetext{
84 "É parte do decorum do sermão, portanto, adaptar-se à ocasião para modificá-la segundo uma Ordem que lhe é superior, a fim de atualizar a palavra divina e mover o auditório de maneira eficaz" (PÉCORA, 2016, p. 14 - grifo do autor).

${ }^{85}$ Aplica-se o expediente que Alcir Pécora (2016, p. 53) percebeu no Sermão da Quarta-Feira de Cinza: "Vieira retarda o quanto pode, contudo - bem de acordo com o preceito engenhoso de suspender os ânimos do auditório -, a explicação do que entende ser essa morte voluntária".
} 
colhidos dentro e fora das escrituras, censura os aduladores, que fingem amar o rei. Nas seções finais, embora faltasse a "Peroração" ${ }^{86}$, exorta os ouvintes a $\operatorname{amar}^{87}$ e serem obedientes a Deus e a Dom João IV, como dispunham o Evangelho e as Leis do reino, em conformidade com o conceito de corpo místico. Sob esse aspecto, ele parece seguir as antigas lições que orientavam a educação e a prática dos religiosos, desde muito jovens, como recomendava a Cartinha com os Preceitos e Mandamentos da Santa Igreja de João de Barros, que circulou no reino a partir de 1539:

[...] deixadas muitas divisões que os católicos fazem do ofício da missa, nós o repartimos em três partes para os meninos, cuja esta obra é para que tenham doutrina conforme a sua idade. A primeira parte será material: em que se contém as coisas materiais dela, com declaração do que significam. A segunda espiritual, em que se tratam [sic] das orações, modulações, autos e cerimônias espirituais, dando delas alguns significados e é assim que os pontífices as ordenaram. A terceira será moral, em que veremos o que deve fazer todo fiel Cristão enquanto nela estiver (BARROS, 2008, p. 99).

Em possível aplicação do ensinamento de Barros, no Sermão da Sexagésima, Vieira defende o discurso claro e didático em contraposição ao "xadrez de palavras", promovido, segundo ele, pelos oradores dominicanos: "Mas como em um pregador há tantas qualidades, e em uma pregação tantas leis, e os pregadores podem ser culpados em todas; em qual consistirá essa culpa? No pregador podem-se considerar cinco circunstâncias: a Pessoa, a Ciência, a Matéria, o Estilo, a Voz. A pessoa que é; a ciência que tem; a matéria que trata; o estilo que segue; a voz com que fala" (VIEIRA, 2015a, p. 53).

Consideremos o emprego dessas "cinco circunstâncias", no Sermão da Primeira Sexta-Feira da Quaresma. A Pessoa (Antônio Vieira) dispunha de vasto conhecimento (Ciência), repertório (Matéria), decoro (Estilo) e eloquência (Voz). Recordando-se que o assunto de que o sermão tratava (Inventio), era exortar o Príncipe a amar aos inimigos

\footnotetext{
86 “Jacinto do Prado Coelho justifica essa aparente falha na estrutura do sermão dizendo que ela se ficaria a dever ao pudor de Vieira em afrontar o Rei que muito presumivelmente assistiria à pregação: ' $O$ sermão de Vieira apresenta a estrutura consagrada: compõe-se (...) finalmente da 'peroração', em que, tirando do que foi dito o ensinamento, exorta os fiéis a pô-lo em prática” (LEMOS; RAMON, 2015, p. 20).

87 "O que essas práticas visam produzir é a imagem, ao mesmo tempo verossímil e persuasiva, do poder político e de sua legitimidade para a adesão de auditórios variados às finalidades do Estado e da Igreja. No limite, o que eles visam é a produção afetiva da concórdia (ou uma ordem fundada no amor) dos vassalos da coroa, distribuídos hierarquicamente, sem que isso se separe da sua própria razão de ser: a saúde do corpo místico do império" (LUZ, 2013, p. 52).
} 
e se precaver contra os aduladores, passemos à Dispositio. Distribuído em nove partes, o sermão foi organizado como abordagem proporcional da matéria, sugerindo que, tanto as sentenças que produziriam maior flama, quanto os períodos frasais que sugerem menor potência durante a enunciação, reforçam o éthos do orador e pretendiam afetar as paixões do seleto auditório Real. É possível que a preocupação com o ajuizamento do seleto auditório teria levado Vieira a recorrer a determinados repertórios, adequados ao assunto que explanaria, em conformidade com o estilo conveniente para produzir maior efeito e persuadir os ouvintes, como ensinava Santo Agostinho:

A Bíblia, para Agostinho, discorria sempre sobre assuntos decisivos e importantes para a salvação da alma, servindo-se destes três estilos conforme a finalidade do seu discurso. Transmitia conceitos pelo estilo simples; louvava e censurava pelo estilo médio; persuadia pelo estilo sublime (BENTO, 2019, p. 55).

A maneira como as partes do sermão foram dispostas reforçava não só a exposição em breves etapas de argumentos retos, claro e didáticos, mas também reproduzia, em diferente escala, o modo ordenado das seções e a subordinação sintática dos períodos. Dessa perspectiva, o sermão estava para as suas partes, assim como estas para os períodos frasais. A subordinação sintática das frases também refletiria, na esfera microtextual, a submissão dos membros-ouvintes à Igreja e ao Reino? ${ }^{88}$ Hipótese a considerar. De todo modo, o que sabe é que a dupla sujeição permeava a forma mentis e a condução dos homens, como mostrou Joseph Höffner:

Da cristianização do antigo império surgiu o ideal de dois chefes à frente da cristandade, Papa e Imperador. Tornou-se tarefa sumamente difícil a separação clara entre as esferas religioso-pontifícia e político-imperial, devido à profunda penetração da mentalidade religiosa cristã em todos os domínios da vida medieval (HÖFFNER, 1986, p. 21).

O exame das nove partes do Sermão da Primeira Sexta-Feira da Quaresma pode ilustrar o senso de proporção aplicado ao texto, quando de sua provável reescrita. Duas partes (I e II) estão voltadas para a introdução da matéria. Cinco partes (III a VII), para o

88 “Percebemos (...) a necessidade de entender Vieira e suas ideias dentro da 'gramática' da época, sem buscar no jesuíta um pensador moderno e progressista ou ainda um 'teólogo da libertação avant la lettre'." (LIMA, 2004, p. 23). 
desenvolvimento das hipóteses. Duas partes (XVIII e IX) contêm as teses com que Vieira confirma as hipóteses. Aproximemo-nos do texto, conforme ele se divide:

Seção I - "As Pessoas soberanas são superiores a toda a Lei, e por isso será necessário examinar exatamente até onde se estende o preceito de Cristo, e resolver com a Graça do mesmo Senhor, e sem lisonja de nenhum outro, se são obrigados também os Reis a amar seus inimigos". Seção II - "Não seriam as Majestades Majestades, se se sujeitassem a amar. Por quê? Por outras duas razões de sua parte. Amar é inclinar-se a vontade primeiro, e depois render-se; e o render-se é contra a potência da Majestade, o inclinar-se contra a soberania". Seção III - "De tão longe ia Deus estabelecendo, e fundando já o preceito que hoje havia de promulgar por Sua própria boca, ensinando com tão graves, e temerosas experiências aos Reis que quando dissesse: Ego dico vobis, também falava com eles". Seção IV - "A maior autoridade, e soberania dos Reis é que nas controvérsias com outros Príncipes estranhos eles sejam, e Deus fiasse deles o serem juízes em causa própria". Seção V - "É certo que [os aduladores] não são os que lavram os campos, nem os que aram os mares, nem os que presidiam as torres, nem os que pleiteiam nos Tribunais, nem os que comerceiam nas praças, nem mesmo os outros, que com o trabalho de suas mãos servem à República, e só conhecem de Palácio as paredes, e as adoram de fora". Seção VI - "E posto que as suas palavras (como pede o respeito, e reverência real) se pronunciem vestidas, ou adornadas com alguns daqueles enfeites, que popularmente se chamam lisonjas, nem por isso desmerece o afeto de seus corações o nome de amigos, e verdadeiros amigos". Seção VII - "[...] é bênção, ou fatalidade dos Reis que tudo o que fizerem, ou quiserem, ainda que não seja louvável, seja louvado”. Seção VIII - “[...] como o Norte sempre fixo do adulador é o interesse, e conveniência própria, nenhum há que se fie deste seguro real, e todos temem arriscar a graça, onde têm posta esperança. Dizia Sêneca (e dizia o que obrava) que 'antes queria ofender com a verdade, que agradar com a lisonja". Seção IX - “[...] adular é querer mal, e ser adulador é ser inimigo; e quantos são os euges que vos dizem, tantos são os males que vos querem" (VIEIRA, 2015a, pp. 197-223)

Percebe-se que o discurso se orienta simultaneamente em múltiplas direções, para além da caracterização de amigos ou aduladores do reino. Antônio Vieira discorre sobre temas muito caros aos jesuítas, dentre os quais, a dupla hierarquia do Amor, natural, em relação a Deus; compulsório, dos súditos em direção ao Rei (Seções I e II); a 
hierarquia aplicável a todos os católicos em relação a Deus (Seção III); a guerra justa, como prova de amor, pois se faria o bem por intermédio da correção moral no campo de batalha (Seção IV); o lugar dos amigos e dos aduladores no reino (Seção V); os modos de reconhecer os amigos do Rei (Seção VI); o poder soberano dos Reis (Seção VII); os expedientes utilizados pelos aduladores (Seção VIII); a simulação de amizade por meio da lisonja (Seção IX).

Neste caso, o discernimento do ouvinte envolveria quatro faculdades: compreender a matéria de que Vieira tratava; identificar as técnicas a que recorrera, ao inventar e dispor as partes do sermão; estabelecer relação entre os reis, teólogos e filósofos, evocados no sermão, com a sabedoria ${ }^{89}$ que se espera dos homens poderosos e discretos, em particular Dom João IV; aplicar o preceituário, apresentado pelo jesuíta, à conduta do súdito que o escutava pregar.

\section{Artifício}

Alcir Pécora (2008, pp. 40-46) salienta que a construção da imagem de Antônio Vieira variou sobremodo ao longo dos tempos. Dentre as virtudes e vícios apontados pela extensa fortuna crítica e biográfica do jesuíta, discorre-se sobre beletrismo, oportunismo, altruísmo e humildade; reafirma-se a sua incansável ação apostólica; atrela-se a ele a estatura de Pajé-Açu etc., o que não impede ver em parte de suas palavras e condutas, gestos judaizantes e, portanto, suspeitos de heresia. Seria um truísmo lembrar que, assim como havia múltiplos Vieiras, existiam várias espécies de sermão, dispostos segundo o teor da matéria, os pressupostos que os animavam, os métodos que os embalavam, os estilos convenientes e os fins pretendidos pelo orador, tendo em vista o auditório a quem se dirigia. $\mathrm{O}$ ato de pregar era observado com extrema atenção por aqueles que escutavam o orador falar. Ainda Lemos e Micaela Ramon (2015, p. 11) lembram que:

\footnotetext{
89 “Um dos preceitos mais recorrentes e fundamentais tanto nas Diatribes como no Encheiridon de Epicteto é a distinção entre aquilo que está sob o controle da razão humana e aquilo que não está. O que o ser humano controla é apenas sua prohairesis: seu 'propósito moral' ou sua capacidade de antecipação e escolha prévia, para que faça o uso correto das 'impressões externas' das phantasias (conforme, por exemplo, Diatribes, I, 1; e Encheiridon, 1). Dessa forma, uma conduta virtuosa, para Epicteto, resume-se ao sustine et abstine: é preciso negligenciar as coisas externas para que se mantenha o 'propósito moral' (Encheiridon, 13)" (LACHAT, 2016, p. 21).
} 
[...] o sermão foi não só o gênero literário predominante, mas também a base da mais importante cerimônia social do século XVII: a pregação. Através dela, a palavra do orador atingia todas as camadas sociais e, por isso mesmo, o ato de pregar revestia-se de uma importância fundamental. (...) Daí que o púlpito fosse utilizado como tribuna ideal não só para a difusão da palavra de Deus, como também para o comentário crítico da vida pública.

Em sua já citada Cartinha, João de Barros havia produzido uma metáfora que aproximava o sino da igreja e o padre da missa, um a chamar, outro a exortar os fiéis: "O vaso do sino significa a boca do pregador, e em ser de metal, denota a força de seu entendimento. E o badalo, que o faz soar dando em uma e em outra parte, é a língua do pregador que toca em ambos os testamentos, o Novo e o Velho" (BARROS, 2008, p. 99). Esse tipo de imagem, sugerida pela aproximação de objeto e função, assume a componente alegórica ${ }^{90}$, maiormente nos sermões, o que explica, no caso de Vieira, o constante recurso ao dogma e a demais preceitos, com que redimensiona a dimensão das figuras para quem ou sobre as quais discorre. Inicialmente, poderíamos sugerir que o sermão é arte que, orientada por preceitos, preceitua. Ou seja, calcado em preceitos retóricos, fundado no dogma e obediente às leis, canônica e civil ${ }^{91}$, pressupõe performance ajustada ao modo como é composto, ordenado e enunciado. Como afirma João Adolfo Hansen (2018, pp. 75-76):

Tanto os sujeitos de enunciação quanto os destinatários implícitos são modelados com caracteres que os particularizam e posicionam como membros de estamentos e ordens sociais do corpo místico do Estado ou membros da unidade de uma mesma vontade coletiva subordinada ao rei no pacto de sujeição. Dramatizados pela actio, a ação do corpo, e pela pronuntiatio, a voz da enunciação, os discursos orais constituíam seus destinatários implícitos como membros da totalidade do "público" colonial, unificado e hierarquizado nas representações como testemunhos da sua própria subordinação ao bem comum do Império.

\footnotetext{
90 “O uso da alegoria na parenética é fundamental, uma vez que o sermão atualiza a palavra de Deus para a audiência. Assim, as estratégias de acomodação do texto bíblico à realidade vivida pelos fiéis, por meio, no caso de Vieira e dos demais pregadores jesuítas de seu tempo, pelo menos, de uma retórica reaquecida pelos retores da Companhia, passam não apenas pelo conhecimento desse maquinário retórico, mas também do teológico, do qual não se separam" (MARTINI, 2019, p. 101).

91 "A coroa é um corpo composto, segundo uma hierarquia particular, pelo rei e pelos magnatas, corresponsáveis pela condução do corpus mysticum. Na teologia política neotomista, própria do universo político ibérico dos séculos XVI, XVII e XVIII, tal noção de coroa se articula à tópica da 'obediência ao poder público' como algo inscrito na lei natural. Para Francisco de Vitória, por exemplo, o poder da sociedade política tem sua origem na Providência, que reúne os cidadãos como parte de um só corpo, mantendo-o como totalidade indivisível. Assim, por um lado, o cargo real é a corporificação da união mística do povo, sob uma mesma coroa, na persona ficta do governante a quem se deve obediência; por outro, há um compromisso inalienável do rei com os cidadãos na distribuição de responsabilidade em relação ao bem comum" (LUZ, 2013, p. 38).
} 
Margarida Miranda (2008, p. 269) propõe que os expedientes retóricos se coadunavam a outros artifícios, empregados com maestria por Antônio Vieira:

Com a metáfora da funda de David, o Padre António Vieira expunha a sua convicção sobre a eficácia da palavra como arma de arremesso, que derruba, fere e vence os inimigos. $O$ orador não esquecia porém que era necessário pregar palavras e obras. O poder persuasivo dos sermões de Vieira deveu-se também certamente ao éthos do pregador. O topos "pratica o que pregas", lugar comum da tradição apostólica mas também da tradição retórica pagã, é abundantemente ilustrado pela pregação de Vieira, nomeadamente pela já apresentada metáfora bíblica da funda de David: "Antigamente convertia-se o mundo; hoje porque não se converte ninguém? Porque hoje pregam-se palavras e pensamentos, antigamente pregavam-se palavras e obras. Palavras sem obras são tiro sem bala; atroam mas não ferem. A funda de David derrubou o gigante, mas não o derrubou com o estalo, senão com a pedra (...)".

Para os fins desta breve reflexão, consideremos os artifícios enunciativos explicitados pelo pregador no Sermão da Primeira Sexta-Feira da Quaresma. Nele, há pelo menos quatro passagens em que Vieira chama atenção para aspectos relacionados à matéria, ao estilo e ao expediente retórico empregado na construção do próprio discurso. Esses expedientes se localizam nas seções finais do sermão. Desnudados pelo orador, os artifícios parecem redobrar, pela aparente transparência do método e a flama controlada pelo pregador, a consistência teológico-política e a sinceridade exortativa dos argumentos. Recorde-se que o sermão foi pregado para um auditório seleto e se dirigia especialmente ao Rei Dom João IV. Na transição entre as seções VI e VII, lemos o seguinte:

[...] quantos forem em Palácio os inimigos de seus interesses, tantos são os inimigos dos Reis. E se eles disserem que são isto discursos, também eu folgara muito que não só foram discursos, senão muito mal fundados, e muito falsos; mas no nosso mesmo Texto o Benefacere é prova do Diligere: Diligite, et benefacite (VIEIRA, 2015a, p. 215).

Vieira relembra o nexo causal entre amar (Diligere) e fazer o bem (Benefacere), em conformidade com a disposição hierárquica da Corte. Assim como os desígnios de Deus, a vontade dos Reis não pode ser colocada em questão. Quando um súdito age contrariamente aos "interesses" do soberano, procede como "inimigo interno", um "adulador". Se se tratar de um cortesão, ou seja, de um membro do palácio, deverá ser apontado e denunciado como adulador, e não amigo do Rei. 
Na sétima parte, topamos com esta curiosa analogia: “[...] para que eu também acrescente a minha comparação, são parecidos os aduladores àqueles quatro animais do Apocalipse" (Idem, ibidem, p. 217). Neste excerto, o pregador afeta modéstia ao acrescentar a "sua" comparação àquelas que colheu em numerosas fontes, tanto teologais quanto filosóficas. Ao construir a imagem por aproximação, pretende colaborar com o rebaixamento moral e físico dos aduladores, identificados às duas bestas que aparecem no livro Apocalipse. Uma delas lembrava um leopardo com cabeça de leão e patas de urso. A segunda besta, emergido da terra, teria dois chifres, o que lembrava a figura de um cordeiro. O adulador, inimigo palaciano, seria um leopardo disfarçado em cordeiro? Parece que sim, tendo em vista de que as más intenções do inimigo do rei seriam mascaradas pelo discurso elogioso, mas bajulador e falso.

Já na oitava seção, lê-se: "Reparai muito nesta última cláusula, que em moral, e político sentido fecha admiravelmente todo o nosso discurso: Quia santificatio Regis est, et domus Regni est" (Idem, ibidem, p. 221). No excerto, Antônio Vieira ressalta que o adulador não tem coragem de dirigir críticas ao soberano. Por isso, reaproveita a sentença que descreve o Palácio como sinédoque dos súditos do Rei. Decorre daí a interpretação de Vieira, para quem as ações do Rei costumam ser santificadas, jamais criticadas, pelos aduladores (que costumam ser os mais próximos, espacialmente, em relação ao monarca). Na última seção (IX), encontra-se o seguinte:

\begin{abstract}
Suposto pois que os aduladores são inimigos dos Reis, e os Reis como todos os outros Cristãos têm também obrigação de amar a seus inimigos, e fazer-lhes bem; seguia-se agora exortar os Príncipes a este amor, e beneficência; Diligite inimicos vestros, et benefacite his, qui oderunt vos. Mas este meu Sermão hoje será a primeira oração Evangélica, que contra todas as Leis da Retórica acabará sem peroração (VIEIRA, 2015a, pp. 222-223).
\end{abstract}

Nessa passagem, Vieira recorda a tese de que os aduladores são inimigos dos Reis, à qual emenda o preceito cristão de que é preciso amar os inimigos. Embora afirme que o sermão não contivesse "peroração" - parte final do discurso em que o orador apela à compaixão do ouvinte (o movere, ensinado por Cícero e Quintiliano) -, a última seção é exortativa e cumpre precisamente a função de deslocar (portanto, mover) as paixões do auditório. $\mathrm{O}$ fato de o orador negar que recorresse à peroração não impediu que buscasse sensibilizar os ouvintes: ponto alto de sua fala do púlpito, concebida e performada para a elocução ora sóbria, ora inflamada, ora tênue. Antônio Vieira não só 
estava consciente de "todas as Leis da Retórica", como também afetava a impassibilidade de um sábio (gesto sabidamente caro aos estoicos), como sinal de moderação, entendimento e memória dos ensinamentos de Jesus Cristo. Os lances finais pretendiam reavivar a chama dos ouvintes, uma vez seduzidos pelos artifícios forjados pelo discurso íntegro, pronunciado por um pregador que projetava um éthos virtuoso (aparentemente honesto e espontâneo), que performava eficaz e eficientemente o papel de conselheiro, e não de adulador, do rei.

Talvez fosse o caso de retomar a ideia de que o sermão materializava procedimentos em acordo com a matéria, o modo como ela era distribuída e se adequava à elocução conveniente do pregador. Compreendido como gênero discursivo que previa e ensinava determinado auditório (ora mais, ora menos homogêneo), para o sermão convergiam preceitos com que se prescreviam modos de conceber, agir e ser. Claro está que esses modos não se aplicavam da mesma forma e com a mesma intensidade aos variados membros do corpo místico, afixados pela rígida hierarquia administrativa. Antes de tudo, o sermão reforça a partição da sociedade de antigo estado português. A caridade do Rei era tão superior quanto o éter e não se confundia com o amor compulsório que emanaria dos súditos. Por sua vez, o homem branco e católico, duplamente submetido à "verdadeira" fé e às leis do reino, distanciava-se do gentio - descrito como criatura bárbara, inocente e inconstante desde a "conquista" de Pindorama92.

\footnotetext{
${ }^{92}$ Sob esse aspecto, o Sermão da Primeira Sexta-Feira da Quaresma, pregado em 1651, conversaria com a Relação da Missão de Ibiapaba, anos à frente, mediante a premissa de que Portugal representaria o Quinto Império. De acordo com Fernanda dos Santos (2018, p. 66): "A ideia naturalizada de que os povos indígenas servem de coadjuvantes e que suas decisões de se confederarem aos holandeses se deve a uma fragilidade espiritual originada na inocência desenvolve-se, segundo toda a argumentação no relato, devido à sua falta da verdadeira fé (o cristianismo católico romano sob a égide de Portugal), o que favorece a ação do mal. A ideia dialoga, claramente, com as teorias quinto-imperialistas".
} 


\section{Referências}

AGOSTINHO, Santo, Bispo de Hipona. A Trindade. 6a reimp. Trad. Augustinho Belmonte. São Paulo: Paulus, 2016.

BARROS, João de. Cartinha com os Preceitos e Mandamentos da Santa Madre Igreja. São Paulo: Humanitas/Paulistana, 2008 [Org. Gabriel Antunes de Araújo].

BENTO, Emilson José. Retórica e Exegese na Pregação Cristã. In: HUBERT, Elizabete Enz; Retórica e Discurso - fronteiras e interfaces: das origens aos desdobramentos atuais - Homenagem à Professora Lineide do Lago Salvador Mosca. Campinas: Pontes, 2019, pp. 47-67.

BíBLIA de Jerusalém. 10ạ reimp. São Paulo: Paulus, 2015 [Coord. Gilberto da Silva Gorgulho; Ivo Storniolo; Ana Flora Anderson].

BOXER, Charles R. A Igreja Militante e a Expansão Ibérica (1440-1770). Trad. Vera Maria Pereira. São Paulo: Companhia das Letras, 2007.

CONCÍlIO Ecumênico de Trento (1545-1563) - Contra as Inovações Doutrinárias dos Protestantes. Petrópolis: Vozes, 1953.

HANSEN, João Adolfo. Razão de Estado. In: Agudezas Seiscentistas e Outros Ensaios. São Paulo: Edusp, 2019, pp. 75-96 [Org. Cilaine Alves Cunha; Mayra Laudanna]. O Discreto. In: . Agudezas Seiscentistas e Outros Ensaios. São Paulo: Edusp, 2019, pp. 97-122 [Org. Cilaine Alves Cunha; Mayra Laudanna].

Retórica e Actio nos Discursos Coloniais. In: DAHER, Andrea. Oral por Escrito: a oralidade na ordem da escrita, da retórica à literatura. Chapecó: Argos; Florianópolis: Editora UFSC, 2018, pp. 61-85.

HÖFFNER, Joseph. Colonização e Evangelho: Ética da Colonização Espanhola no Século de Ouro. 3 a ed. Trad. José Wisniewski Filho. Rio de Janeiro: Presença, 1986.

LACHAT, Marcelo. "Os Sermões de Quarta-Feira de Cinza do Padre Antônio Vieira e a Arte de Morrer Estoico-Cristã". Revista Literatura e Sociedade, n. 23, pp. 11-26, 2016.

LEMOS, Ainda; RAMON, Micaela. "Introdução". In: Obra Completa, T. II., V. II - Sermão da Sexagésima e Sermões da Quaresma. São Paulo: Loyola, 2015, pp. 9-27.

LIMA, Luís Filipe Silvério. Padre Vieira: Sonhos Proféticos, Profecias Oníricas: o Tempo do Quinto Império nos Sermões de Xavier Dormindo. São Paulo: Humanitas, 2004.

LUZ, Guilherme do Amaral. Produção da Concórdia: Poética do Poder na América Portuguesa. In: Flores do Desengano: Poética do Poder na América Portuguesa. São Paulo: Fap-Unifesp, 2013, pp. 33-56. 
MAQUIAVEL, Nicolò. O Príncipe. Trad. Maurício Santana Dias. São Paulo: Penguin Books/Companhia das Letras, 2010.

MARTINI, Marcus de. A alegoria nos sermões de Padre Antônio Vieira: algumas questões sobre seu emprego e terminologia. Revista Letras, Especial n. 1, Santa Maria, pp. 89-120, 2019.

MIRANDA, Margarida. Sem a Voz que os Animou, Ainda Ressuscitados São Cadáveres: Actio e Declamatio na Formação de Vieira, Pregador. Revista Humanitas, $n$. 60, pp. 267282, 2008.

MUHANA, Adma. Introdução. In: . Os Autos do Processo de Vieira na Inquisição (1660-1668). São Paulo: Edusp, 2008, pp. 13-29.

PÉCORA, Alcir. A Arte de Morrer, segundo Vieira. In: VIEIRA, Antônio. Sermões de Quarta-Feira de Cinza. Campinas: Editora Unicamp, 2016, pp. 9-66 [Org. Alcir Pécora].

- Teatro do Sacramento: a Unidade Teológico-Retórico-Política dos Sermões de Antônio Vieira. 2a ed. Campinas: Editora Unicamp; São Paulo: Edusp, 2008.

. Vieira e a Condução do Índio ao Corpo Místico do Império Português (Maranhão, 1652-1661). In: COSTIGAN, Lúcia Helenda (org.). Diálogos da Conversão. Campinas: Editora Unicamp, 2005, pp. 83-98.

PERELMAN, Chaïm; OBRECHTS-TYTECA, Lucie. Tratado da Argumentação: A Nova Retórica. Trad. Maria Ermantina Galvão G. Pereira. São Paulo: Martins Fontes, 1996.

SANTOS, Fernanda Cristina da Encarnação dos. A Retórica da Alteridade na "Relação da Missão da Serra da Ibiapaba, do Padre Antônio Vieira". Tese de Doutorado. UFES, 2018.

VIEIRA, Antônio. "Carta 53 - Ao Rei D. João IV". In: Obra Completa, T. I, V. I Cartas Diplomáticas. São Paulo: Loyola, 2014, pp. 293-294 (Dir. José Eduardo Franco; Pedro Calafate. Coord. Carlos Maduro).

. "Carta 54 - Ao Príncipe D. Teodósio". In: . Obra Completa, T. I, V. I - Cartas Diplomáticas. São Paulo: Loyola, 2014, pp. 295-297 [Dir. José Eduardo Franco; Pedro Calafate. Coord. Carlos Maduro].

. "Sermão da Sexagésima". In: Obra Completa, T. II., V. II - Sermão da Sexagésima e Sermões da Quaresma. São Paulo: Loyola, 2015a, pp. 43-73 [Dir. José Eduardo Franco; Pedro Calafate; Coord. Aida Lemos; Micaela Ramon].

. "Sermão da Primeira Sexta-Feira da Quaresma". In: . Obra Completa, T. II., V. II - Sermão da Sexagésima e Sermões da Quaresma. São Paulo: Loyola, 2015a, pp. 197-225 [Dir. José Eduardo Franco; Pedro Calafate; Coord. Aida Lemos; Micaela Ramon]. 
"Sermão pelo Bom Sucesso das Armas de Portugal Contra as de Holanda". In: . Obra Completa, T. II., V. XIII - Sermões de Incidência Política. São Paulo: Loyola, $\overline{2015 b}$, pp. 73-95 [Dir. José Eduardo Franco; Pedro Calafate; Coord. Luís Machado de Abreu]. 


\section{A «expulsão dos jesuítas» como lugar-comum}

[...] aquela boa fé e sinceridade, que é própria de Príncipes tão justos, tão amigos, $e$ parentes. ${ }^{93}$

[...] en bonne Philosophie, toute déduction qui a pour base des faits ou de vérités reconnues, est préférable à ce qui n'est appuyé que sur des hypothèses, même ingènieuses. ${ }^{94}$

Mouros, brancos, negros, mulatos ou mestiços, todos servirão, todos são homens e são bons, se bem governados. ${ }^{95}$

\section{Premissas}

Em Lições de História do Brasil, publicada originalmente em 1860, o médico, romancista, jornalista, político e professor Joaquim Manuel de Macedo (1820-1882) dedicou um punhado de páginas à reforma do ensino em Portugal e seus domínios, processada em meados do século XVIII. Amigo do Imperador Pedro II, Macedo se mostrava francamente favorável às iniciativas atribuídas a Sebastião José de Carvalho e Melo, durante o governo absolutista de D. José I, o que reforça o seu alinhamento ideológico com a política central e conservadora do monarca brasileiro, em respeito a suas raízes de além-mar.

93 Tratado de Madrid, 1750. Cf. José Carlos de Macedo Soares, Fronteiras do Brasil no Regime Colonial, 1939, p. 145

94 «[...] em boa Filosofia, toda dedução que tem por base factos e verdades reconhecidos é preferível àquela que se apoia exclusivamente sobre hipóteses, ainda que engenhosas» (Denis Diderot e Jean Le Rond D'Alembert, "Discours Préliminaire des Editeurs», Enciclopédia, ou Dicionário razoado das ciências, das artes e dos ofícios, trad. Fúlvia Moretto e Flavia das Graças de Souza, São Paulo, Editora Unesp, 2015, p. 48 - tradução minha). Apesar de reconhecer o excelente trabalho de Moretto e Souza, optou-se por traduzir de outro modo a epígrafe extraída da Enciclopédia.

${ }^{95}$ Carta de Silva-Tarouca, de Viena, a Pombal - em 12 de agosto de 1752 (Cf. Kenneth Maxwell, Marquês de Pombal, paradoxo do Iluminismo, 2. - ed., trad. Antônio de Pádua Danesi, Rio de Janeiro, Paz e Terra, 1997, p. 54). 
O tema «expulsão dos jesuítas» era matéria do vigésimo oitavo capítulo de uma obra largamente utilizada pelo então docente e, em princípio, destinada aos seus alunos do tradicional Colégio Dom Pedro II - onde Joaquim Manuel atuou de 1849 até o final da vida. Ou seja, as Lições constituíam material integrante do Programa Oficial da renomada instituição.

Não se tratava de negar a convenção, tampouco de inovar nos métodos de ensino na cadeira História do Brasil. Pelo contrário. No livro, a reduzida quantidade de informações, somada ao tom apologético em torno da figura de Pombal, constituía um dos traços característicos da mentalidade de nossa elite e, por extensão, do alunado em formação durante o Segundo Império. É curioso o modo como o autor se expressava. Dando voz ao próprio Joaquim Manuel de Macedo, em 1750, o Rei D. José I teria chamado «ao seu conselho o célebre Sebastião José de Carvalho e Melo [...] notável estadista, cujo nome jamais será esquecido» ${ }^{96}$.

Esse traço, entre ufanista e hiperbólico, com que Macedo manifestava solidariedade a Pombal e elogiava a trajetória do polémico ministro, em firme contraposição aos jesuítas, encontraria uma perspetiva oposta, décadas depois. Foi o caso de Manoel Bomfim, um dos primeiros pesquisadores brasileiros na década de 1930 a relativizar o papel atribuído ao braço direito de Dom José. A seu ver, Pombal não passava de um:

Estadista de ribalta [...], sem a inteligência sentida e intuitiva, como no verdadeiro estadista, timbrando em tudo desfazer, para reorganizar nos lineamentos do seu plano, ele foi, de fato, um desorganizador [...] Tal se verifica no caso dos índios do Brasil: libertou-os definitivamente, ao mesmo tempo que afastou os padres; e, como não era capaz de conceber uma organização eficaz em substituição, deixouos desamparados, em pior condição ${ }^{97}$.

Contestações à perceção virtuosa de Pombal continuaram a pautar as obras de larga envergadura, por aqui. Na década de 1960, sob a direção de Sérgio Buarque de Holanda, os autores da História geral da civilização brasileira foram ainda mais longe do que Bomfim, ao contestar as motivações que embalaram o Conde de Oeiras:

\footnotetext{
${ }_{96}^{6}$ Joaquim Manuel de Macedo, Lições de História do Brasil - para uso das escolas de instrução primária, Rio de Janeiro, Garnier, 1905, p. 255.

${ }_{97}$ Manoel Bomfim, O Brasil na história: deturpação das tradições, degradação politica, Rio de Janeiro, Topbooks, 2013, pp. 325-326.
} 
Havia muito que os jesuítas eram acusados de enriquecer à custa dos índios, de privilégios e isenções; na realidade, a organização e a parcimônia explicariam muita prosperidade que causava inveja. Agora eram também responsabilizados pelo malogro da marcação de limites, pela rebelião no Uruguai, por dificuldades opostas à Companhia de Comércio do Maranhão ${ }^{98}$.

Em 1961, o embaixador Teixeira Soares sintetizaria as não-razões para a expulsão dos jesuítas, recorrendo ao ineditismo de suas ações - supondo-as incompreendidas pelas Coroas de Portugal e Espanha, àquela altura:

Os Jesuítas foram paladinos de uma justiça social, no tempo incompreensível. Por isso, foram encarados com suspeita tanto pelas autoridades coloniais, bem como pelas de Roma. O Estado absolutista espanhol, como os demais da Europa, miravam com desconfiança os empreendimentos jesuíticos na selva paraguaia, entendendo que essa obra civilizadora poderia levar talvez à verdadeira criação de um «Estado independente». Na memória que redigiu para Dom José I, Pombal reuniu copiosa informação para justificar que entre os rios Paraguai e Uruguai existia um «florente império», onde se acumulavam imensas riquezas ${ }^{99}$.

Tom similar se verifica na extensa e abrangente História do Brasil, de Hélio Vianna, publicada pela primeira vez em 1962:

Ao Marquês de Pombal, como aos seus prepostos no Brasil, pareceu evidente que na resistência houvera ação sub-reptícia dos inacianos, apesar de todas as negativas destes. Na Amazônia, muitas foram as revelações das autoridades, encabeçadas pelo Governador, que era irmão daquele Ministro, Francisco Xavier de Mendonça Furtado, de que os jesuítas demonstravam má vontade e falta de apoio às demarcações, que de acordo com o Tratado de Madrid deviam ser feitas. Sonegavam, por exemplo, os indígenas canoeiros que de suas aldeias deveriam fornecer. Além de se oporem, como é sabido, à organização e ação da nova Companhia Geral do Comércio do Grão-Pará e Maranhão ${ }^{100}$.

\footnotetext{
98 Sérgio Buarque de Holanda, História geral da civilização brasileira, Tomo 1, $2^{\circ}$ Volume, Rio de Janeiro, Bertrand Brasil 1997, p. 43.

99 Álvaro Teixeira Soares, O Marquês de Pombal, Brasília (DF), Editora UnB, 1983, p. 145.

100 Hélio Vianna, História do Brasil - Vol. 1, 3ª ed., São Paulo, Melhoramentos, 1965, p. 334.
} 
Os questionamentos em torno da personalidade e atitudes atribuídas (com sinal positivo) a Sebastião José de Carvalho e Melo não se limitam ao Brasil. Em 1982, o português Domingos Mascarenhas objetava que:

Até os seus panegiristas se veem forçados a reconhecer o detestável despotismo de Pombal [...] A oposição dos jesuítas a Sebastião José surgiu no Brasil em resultado da criação da Companhia do Grão-Pará e Maranhão, a qual Ihe terá sido sugerida pelas recordações de sua permanência em Londres ${ }^{101}$.

Por sua vez, o britânico Charles Boxer declarava, com asserção e objetividade, que:

[...] a ditadura do marquês de Pombal declarou (em 1774) que o rei de Portugal, por sua posição de chefe supremo da Ordem de Cristo, era um "prelado espiritual" com jurisdição e poderes «superiores aos dos prelados diocesanos e ordinários das ditas Igrejas no Oriente». Não é necessário dizer que o papado de Roma se recusou a aceitar essas demandas extravagantes e absurdas, mas sua impotência se tornou patente ao mundo inteiro quando da extinção da Companhia de Jesus nos impérios português (1759-1760) e espanhol (1767-9), sem que os respectivos governantes tivessem pedido a autorização do papa ${ }^{102}$.

\section{Legado}

A breve notícia dada por Joaquim Manuel de Macedo, em suas fatiadas Lições de História do Brasil, parece ter reverberado na historiografia brasileira escolar, inspirando considerações breves e descontextualizadas em diversos manuais, haja vista a ênfase nos antagonismos entre os jesuítas e a Coroa, a explicar a cisão que assinalara as bruscas mudanças do período jesuítico (de 1549 a 1760) para o período pombalino (de 1750 a 1777).

Para o antigo professor do Colégio Pedro II, isso se dava porque «Grandes eram a influência e o poder dos padres da Companhia de Jesus. Mas o marquês de Pombal,

${ }^{101}$ Domingos Mascarenhas, Portugalidade, biografia duma nação, Lisboa: Edições FP, 1982, pp. 198-199.

102 Charles Boxer, A igreja militante e a expansão ibérica: 1440-1770, trad. Vera Maria Pereira, São Paulo, Companhia das Letras, 2007, p. 101. 
considerando essa companhia nociva ao Estado, resolveu fazê-la desaparecer dos domínios portugueses» ${ }^{103}$.

O facto é que, de modo geral, o episódio «expulsão dos jesuítas» foi abordado sumariamente em diversos manuais (dedicados ao período colonial luso-brasileiro), utilizados nas escolas brasileiras ao longo do século $\mathrm{xx}$.

Quase sempre, na rivalidade entre o Estado português e a Companhia de Jesus, os membros da Ordem foram (e ainda são) considerados sujeitos privilegiados, embora derrotados e responsabilizados pelo atraso cultural do reino e o deficit económico de suas colónias. A polarização é evidente:

O «todo poderoso ministro» ${ }^{104}$ «enfrentou os jesuítas, expulsando-os dos domínios portugueses» ${ }^{105}$. A despeito das controvérsias, «[...] o todo-poderoso Marquês [...] [de] Pombal venceu o tempo, os ódios e as paixões e impôs-se como grande vulto da história de Portugal» ${ }^{106}$.

Repare-se nos epítetos que parecem ter se irradiado de uma obra a outra; na forma como os historiadores contrapõem o reino (personificado em Pombal) aos jesuítas, com evidente prejuízo para estes. Seria necessário matizar essas informações, embora reconheçamos que são obras panorâmicas. O discurso é marcado por verbos de teor beligerante: «venceu», «enfrentou», «derrotou», «expulsou».

O problema maior é que, ao estabelecer relações apressadas de causa e consequência, determinados autores abordam o tema superficialmente, o que favorece a perpetuação de estereótipos entre os consulentes que acessam tais manuais - para bem ou para o mal dos atores (fossem eles maiores ou menores) envolvidos nos episódios do mundo luso-brasileiro, a protagonizar alguns períodos-chave de nossa história.

Felizmente, a situação vem se modificando, como se nota em algumas obras de referência relacionadas à História do Brasil. No Dicionário do Brasil Colonial, organizado por Ronaldo Vainfas, lê-se no verbete «llustração» que:

\footnotetext{
103 Joaquim Manuel de Macedo, Lições de História do Brasil - para uso das escolas de instrução primária, Rio de Janeiro, Garnier, 1905, p. 256.

${ }^{104}$ A. Souto Maior, História do Brasil, 5. a ed., São Paulo, Companhia Editora Nacional, 1967, p. 171.

105 José Alves de Freitas Neto e Célio Ricardo Tasinafo, História geral e do Brasil, São Paulo, Harbra, 2006, p. 341.

${ }^{106}$ Álvaro Teixeira Soares, O Marquês de Pombal, Brasília (DF), Editora UnB, 1993, pp. 90-91.
} 
Em 1746, o impacto causado pela publicação de uma violenta crítica aos métodos de ensino em voga - escrita por Luís Antônio Verney, patrocinado pela Coroa e colocado a salvo da Inquisição, na Itália - revelou a necessidade de uma mudança. Mudança que se efetivou no reinado seguinte (1750-77), por intermédio da atuação de Sebastião José de Carvalho e Melo, o marquês de Pombal. Típico estrangeirado, ele quis fortalecer a Coroa diante de outros poderes concorrentes, como a Igreja e a alta nobreza, imprimindo em seu governo um caráter violento e arbitrário que pouco condizia com a perspectiva das Luzes ${ }^{107}$.

Heloisa Reichel, autora de um verbete sobre os sangrentos combates nas missões, entre 1753 e 1756, observa que os episódios relacionados à divisão dos territórios, segundo os desígnios do Tratado de Madrid, costumavam ser encarados «de forma positiva» pelos historiadores tradicionais, face à «política de aliciamento desenvolvida pelos portugueses junto aos índios».

Como a estudiosa destaca, em contrapartida, «estudos recentes» sugerem que se tratou de um «processo de desterritorialização dos indígenas» ${ }^{108}$, processado de modo complexo e de forma violenta. A pesquisadora relembra que a Guerra dos Sete Povos das missões foi «marcada pelo grande desequilíbrio existente entre as forças dos exércitos espanhol e português, aparelhados com algumas das melhores armas do período, e as hordas de nativos quase indefesos e despreparados para a luta» ${ }^{109}$.

Sob essa ótica, a pretensão de abrangência em alguns livros não implica necessariamente a falta de precisão. A linguagem mais objetiva e acessível, que costuma caracterizar os manuais voltados ao ensino médio, não deveria ser empecilho para o maior rigor nas informações disponibilizadas pelos autores. É o que revela um dos livros «didáticos» de Paulo de Assunção, que se refere à expulsão dos jesuítas nos seguintes termos:

A divisão proposta no Tratado de Madri, feita à revelia dos interesses e desejos dos jesuítas, afetava os índios e missioneiros que deveriam deslocar-se para as terras demarcadas, suprindo o acordo firmado entre as duas Coroas. [...] Os jesuítas pediram aos monarcas que o Tratado não fosse executado. A justificativa era que as reduções correriam grande risco, e que a paz espiritual e temporal dos índios

\footnotetext{
107 Ronaldo Vainfas (dir.), Dicionário do Brasil Colonial (1500-1808), Rio de Janeiro, Objetiva, 2000, p. 298. 108 Heloisa Reichel, "10 de fevereiro de 1756 - Guerra dos Sete Povos das Missões», in Circe Bittencourt (dir.), Dicionário de datas da história do Brasil, 2. a ed., São Paulo, Contexto, 2012, p. 49.

${ }^{109}$ Idem, Ibidem, p. 47. O episódio «expulsão dos jesuítas» foi abordado mais discretamente no Dicionário de nomes, termos e conceitos históricos, de Antônio Carlos do Amaral Azevedo (1997) e no Dicionário histórico Brasil - Colônia e Império, de Angela Vianna Botelho e Liana Maria Reis (2002).
} 
estaria ameaçada. Entretanto, esses argumentos não chegaram a ser considerados. Os nativos aldeados se revoltaram, dando início às chamadas Guerras Guaraníticas, que duraram de 1754 a 1756. Nesse momento, a oposição aos jesuítas se intensificou: eles foram acusados de não obedecer às resoluções do rei, de interferir em questões do governo e de realizar práticas comerciais. Mas a acusação mais grave era que eles não obedeciam às leis que tratavam da liberdade dos índios e de suas propriedades, nem mesmo às ordens do papa Bento XIV, que expediu bula contra a escravidão dos índios ${ }^{110}$.

Claro esteja: a libertação prometida aos índios estava longe de ser fruto da dádiva reinol ou da súbita generosidade de Furtado Mendonça, de seu irmão Carvalho e Melo ou asseclas.

Importa observar que, em carta endereçada a Gomes Freire de Andrada (governador da região sul), Sebastião José partia da premissa de que «[...] o poder e a riqueza de todos os países consistem principalmente no número e multiplicação das pessoas que os habitam, esse número e multiplicação de pessoas é mais indispensável agora nas fronteiras do Brasil, para suas defesas» ${ }^{111}$.

No tocante às comunidades indígenas sob a tutela portuguesa, na colónia americana, o primeiro-ministro de D. José I defendia a miscigenação entre brancos e índios como fator essencial para o aumento da população:

[...] como não era «humanamente possível» obter o número de pessoas necessárias do próprio Portugal ou das ilhas adjacentes (Açores e Madeira) sem convertê-los "completamente em desertos», era essencial abolir "todas as diferenças entre índios e portugueses» para atrair os índios das missões uruguaias e encorajar o casamento deles com europeus ${ }^{112}$.

Evidentemente, se em diversos livros do ensino médio prevalece certa aura cívica e heroica em torno de Sebastião José, muitos contrapontos foram apontados por autores de trabalhos monográficos, em especial naqueles de maior fôlego e precisão historiográfica e cultural.

\footnotetext{
110 Paulo de Assunção, Os jesuítas no Brasil colonial, São Paulo, Atual, 2003, pp. 33 e 35 - grifo nosso.

${ }^{111}$ Sebastião José Carvalho e Melo apud Keneth Maxwell, op. cit., p. 53.

112 Idem, Ibidem, p. 53.
} 
Por exemplo, no ano seguinte à publicação de História concisa do Brasil, por Francisco Maria Pires Teixeira, Boris Fausto editou sua História do Brasil (1994) ${ }^{113}$, em que apresenta visão bem diferente em relação à de seu predecessor:

Sua obra [de Pombal], realizada ao longo de muitos anos (1750-1777), representou um grande esforço no sentido de tornar mais eficaz a administração portuguesa e introduziu modificações no relacionamento Metrópole-Colônia. A reforma constituiu uma peculiar mistura do velho e do novo, explicável pelas características de Portugal ${ }^{114}$.

Em relação à tão propalada rutura da Coroa com os modelos jesuíticos de ensino, Fausto também ressalva que "A expulsão da ordem abriu um vazio no já pobre ensino da Colônia. $A$ Coroa portuguesa, ao contrário da espanhola, temia a formação na própria Colônia de uma elite letrada» ${ }^{115}$.

Três anos depois, Jorge Caldeira seguiria na mesma direção. «Para o Brasil, isso [a expulsão dos jesuítas] foi um problema. Em duzentos anos, os jesuítas haviam consolidado uma posição importante na política de tratamento dos índios. Também desempenharam papel fundamental no precário sistema de educação colonial »116. Igualmente ponderada é a perceção de Mary del Priore e Renato Venâncio. Recentemente, eles sugeriram que:

Ambos os episódios, no sul e no norte, serviram para desencadear uma feroz perseguição aos jesuítas, acusados por Espanha e Portugal de insuflar a resistência indígena e dificultar as demarcações. A Companhia pagou um preço altíssimo por tanta resistência. Para começar, os jesuítas foram proibidos de entrar nos Paços dos Reis e de serem confessores da família real; a Ordem religiosa teve que se

\footnotetext{
${ }^{113}$ Em 2001, Boris Fausto lançou a sua História concisa do Brasil - uma versão reduzida, amparada em seu estudo mais extenso, publicado sete anos antes. Neste manual, o historiador considera que: «A grande presença de indígenas fez do Norte um dos principais campos de atividade missionária das ordens religiosas, com os jesuítas à frente. Estima-se que, em torno de 1740, cerca de 50 mil índios viviam nas aldeias jesuíticas e franciscanas. Foi importante a ação do padre Antônio Vieira, que chegou ao Brasil em 1653 como provincial da Ordem dos Jesuítas, desenvolvendo uma intensa pregação a fim de limitar os abusos cometidos contra os índios» (Boris Fausto, História concisa do Brasil, São Paulo, Edusp, 2001, p. 49).

${ }^{114}$ Boris Fausto, História do Brasil, São Paulo, Edusp, 2004, pp. 109-110.

${ }^{115}$ Idem, Ibidem, p. 111.

${ }^{116}$ Jorge Caldeira et alii, Viagem pela História do Brasil, São Paulo, Companhia das Letras, 1997, p. 103.
} 
submeter a uma reforma interna e foram, por fim, acusados da tentativa de regicídio contra D. José $\mathrm{I}^{117}$.

Afora as numerosas controvérsias em torno da administração pombalina e de seu irmão, à frente do Estado de Grão-Pará e Maranhão, a partir de 1751, três fatores chamam a atenção: 1) as razões de ordem económica que embasaram as decisões do Reino; 2) o exagerado protagonismo concedido a Sebastião José de Carvalho e Melo; 3) as vicissitudes decorrentes da substituição dos padres por representantes do Estado português. Esses tópicos são abordados nas próximas secções.

\section{Uma retórica dos negócios}

No que diz respeito ao primeiro item, vale a pena conferir o teor da República jesuítica ultramarina, atribuída ao próprio Sebastião José e publicada em Lisboa no ano de 1757. Inicialmente, ele descreve os jesuítas da seguinte forma:

Nos sertões dos referidos Uraguai e Paraguai, se achou estabelecida uma poderosa República, a qual só nas margens e territórios daqueles dois rios tinha fundado não menos de trinta e uma grandes povoações, habitadas de quase cem mil almas; e tão ricas, e opulentas em furtos, e cabedais para os ditos Padres, como pobres, e infelizes para os desgraçados índios, que nelas fechavam como escravos ${ }^{118}$.

Chega a ser irónico que Pombal, frequentemente classificado como tirânico e despótico ${ }^{119}$, aludisse à Companhia da Ordem de Jesus em termos bastante similares:

\footnotetext{
${ }^{117}$ Mary del Priore e Renato Venancio, Uma breve história do Brasil, São Paulo, Planeta, 2010, p. 132.

118 Sebastião José de Carvalho e Melo, República jesuítica ultramarina, Gravataí, SMEC; Porto Alegre, Martins Livreiro; Santo Ângelo, Centro de Cultura Missioneira/FUNDAMES, 1989, pp. 7-8.

119 É possível que o predicado utilizado por Pombal, ao caracterizar os jesuítas, tivesse por base as declarações de seu próprio irmão, quando governador do Estado do Grão-Pará e Maranhão, como se vê nesta carta de Francisco Xavier de Mendonça Furtado, enviada Sebastião José, assinada em 14 de março de 1755: "O primeiro dos referidos negócios consiste no despotismo que pretendem sustentar os regulares [jesuítas] contra a jurisdição real e episcopal e nos monopólios da liberdade dos índios» (Marcos Carneiro de Mendonça, A Amazônia na era pombalina - Tomo II, Brasília (DF), Edições do Senado Federal, 2005[b], p. 319).
} 
[...] ignorando os miseráveis índios, que havia na terra poder que fosse superior ao poder dos Padres, criam que estes eram soberanos despóticos, dos seus corpos e almas, ignorando que tinham Rei a quem obedecer, criam que no mundo não havia vassalagem, mas que tudo nele era escravidão ${ }^{120}$.

No documento que ele assina, a preocupação com os assuntos comerciais, embora disfarçada, é incontestável:

Daquela usurpação da liberdade dos índios, passaram a da agricultura e do comércio daqueles dois Estados, contra a outra resistência de Direito Canônico e das tremendas Constituições Apostólicas estabelecidas contra os Regulares, e muito mais contra os Missionários negociantes. Ultimamente absorveram em si todo o referido comércio; apropriando-se com uma absoluta violência não de todos os gêneros de negócio, mas até dos mantimentos da primeira necessidade da vida humana, com muitos monopólios, também reprovados por Direito Natural e Divino ${ }^{121}$.

Por sua vez, atuando no Norte, o papel de Francisco Xavier de Mendonça Furtado, irmão de Sebastião José de Carvalho e Melo, foi decisivo para as resoluções impostas pela Coroa, desde sua nomeação para o governo do Estado do Grão-Pará e Maranhão. Os estudos sobre sua correspondência permitem que situemos melhor o seu papel face aos interesses de Portugal, como mostraram Márcia Amantino e Marieta Pinheiro de Carvalho:

Em carta de 29 de dezembro de 1751 [Mendonça Furtado] retoma essa questão, realizando diversas críticas aos missionários (capuchos, mercês, carmos, jesuítas) para os quais "a propagação da fé lhes não serve mais que pretexto" para o acúmulo de bens materiais. Sobre os jesuítas que, a seu ver, detinham um «universal comércio» nessas áreas, acusa-os de contrabando e da prática de fraudes, não apenas contra a Companhia portuguesa como também à espanhola, em detrimento do aumento de seu cabedal ${ }^{122}$.

\footnotetext{
${ }^{120}$ Sebastião José de Carvalho e Melo, op. cit., p. 8.

${ }^{121}$ Idem, Ibidem, p. 18.

122 Márcia Amantino e Marieta Pinheiro de Carvalho, "Pombal, a riqueza dos jesuítas e a expulsão», in Francisco Falcon e Claudia Rodrigues, $A$ «Época Pombalina» no mundo luso-brasileiro, Rio de Janeiro, FGV Editora, 2015, p. 76.
} 
As medidas adotadas por Francisco Xavier não se deram no vácuo, nem suscitaram um acordo imediato com a matriz portuguesa. Elas seguiram os vagarosos trâmites burocráticos e se escoravam no firme propósito da Coroa, que também passou a apoiar a administração do Norte, inclusive financeiramente. Mauro Cezar Coelho elenca o tripé ${ }^{123}$ em que se baseavam as premissas do governador do Grão-Pará e Maranhão:

Insinuam-se nas recomendações de Mendonça Furtado três preocupações presentes na política indigenista formulada pela metrópole: primeiramente, o estabelecimento das populações indígenas em unidades populacionais fixas, de forma a proteger o território colonial, através da ocupação efetiva; em seguida, a sua incorporação ao modelo de civilização europeu, pautado no trabalho especialmente o agrícola - percebido não mais, somente, como instrumento de exploração de riquezas, mas como mecanismo de desenvolvimento de valores ocidentais, especialmente a ideia da poupança e do enriquecimento; por fim, a introdução e o fortalecimento da autoridade metropolitana, através do ensino da língua portuguesa ${ }^{124}$.

Cumpre observar que nas Instruções Régias ${ }^{125}$ de 31 de maio de 1751, o rei Dom José I atendeu ao pedido de nomeação de Mendonça Furtado, como governador «na dita cidade do Pará», salientando o principal interesse da Coroa, como se lê no segundo artigo do documento.

O interesse público e as conveniências do Estado que ides governar, estão indispensavelmente unidos aos negócios pertencentes à conquista e liberdade dos índios, e juntamente às missões, de tal sorte que a decadência e ruína do mesmo Estado, e as infelicidades que se têm sentido nele, são efeitos de se não acertarem ou de se não executarem, por má inteligência, as minhas reais ordens que sobre estes tão importantes negócios se têm passado ${ }^{126}$.

\footnotetext{
${ }^{123}$ Naquele tempo, os argumentos apresentados à Coroa por Francisco Xavier de Mendonça Furtado não estavam sujeitos a critérios de originalidade. Pelo contrário, deram forma a antigas reivindicações feitas pelos colonos e antigos administradores da região Norte, e que circulavam entre os portugueses desde o final do século XVII, como demonstrou Dauril Alden (1970) - estudioso que será retomado adiante.

${ }^{124}$ Mauro Cezar Coelho, "A construção de uma lei: o diretório dos índios», Revista do Instituto Histórico e Geográfico Brasileiro, ano 168, n.․ 437, 2007, p. 33.

125 Originalmente, o documento intitulava-se Instruções régias, públicas e secretas para Francisco Xavier de Mendonça Furtado, Capitão-General do Estado do Grão-Pará e Maranhão (Cf. Marcos Carneiro de Mendonça, A Amazônia na era pombalina - Tomo I, Brasília (DF), Edições do Senado Federal, 2005[a], p. 67).

${ }^{126}$ Idem, Ibidem, p. 68 - grifos nossos.
} 
Repare-se que a palavra «negócio» é mencionada (diretamente) duas vezes, num único artigo, sem contar a alusão indireta ao(s) «interesse(s)» do Estado. O caráter pragmático era evidente. Não desprezemos o facto de que, a despeito de os 38 artigos do documento questionarem o desmedido poder e arbítrio dos jesuítas, houvesse a recomendação expressa do rei ao governador de que ele preferisse «sempre os padres da Companhia, entregando-lhe os novos estabelecimentos [...] por me constar que os ditos padres da Companhia são os que tratam os índios com mais caridade e os que melhor sabem formar e conservar as aldeias ${ }^{127}$.

É sintomático que a questão financeira seja mencionada por diversas vezes, nas referidas Instruções, como evidenciam os artigos 13, 14, 27, 31, 33 e 37 . Sobre esse tópico, devese ressaltar um dos estudos mais relevantes a respeito do legado da era pombalina, em que Laerte Ramos de Carvalho questionava a postura adotada por uma parcela dos historiadores, até a década de 1950, no Brasil:

Ainda hoje, os alvarás e provisões pombalinos são examinados como se não houvesse um outro caminho entre a alternativa que então se propôs: jesuitismo e antijesuitismo ${ }^{128}$. Nesta alternativa, os jesuítas representam para os historiadores tudo o que há de antimoderno e Pombal, com seus homens, a autêntica antecipação das aspirações modernas. Ora, forçoso é reconhecer que os termos desta alternativa constituem um dos mais graves impedimentos para a justa compreensão de um dos momentos mais lúcidos da história lusitana ${ }^{129}$.

Para o pesquisador, alguns fatores decisivos, para além das matrizes culturais do Iluminismo, teriam balizado as diversas providências tomadas pela Coroa portuguesa na década de 1750:

\footnotetext{
127 Idem, Ibidem, p. 75.

${ }^{128}$ Sobre essa relevante questão, o historiador José Eduardo Franco foi preciso ao perceber que «Jesuítas e jesuitismo encerram um conceito/visão de carga negativa, pessimista. Representam todo um passado cultural, educativo, mental que urgia repudiar e abolir. O termo Europa situa-se conceptualmente no polo oposto. Expressa uma visão de carga altamente positiva, um conceito luminoso, de dimensão utópica, encerra, no fundo, um ideal, um modelo a seguir» (José Eduardo Franco apud Luiz Eduardo Oliveira, «A invenção da tradição e o mito da modernidade: aspectos principais da legislação pombalina sobre o ensino de línguas», in Luiz Eduardo Oliveira (dir.), A legislação pombalina sobre o ensino de línguas: suas implicações na educação brasileira (1757-1827), Maceió, Edufal, 2010, p. 24.

129 Laerte Ramos de Carvalho, As reformas pombalinas da instrução pública, São Paulo, Edusp, Edição Saraiva, 1978, p. 29.
} 
Este antijesuitismo foi muito mais a consequência das lutas políticas do Gabinete com a Cúria Romana do que verdadeira causa do programa pedagógico formulado pela Junta de Providência Literária [...] De há muito já se sentiam, na vida do país, os inconvenientes que traziam para a economia e o trabalho nacionais o acúmulo de bens imóveis e as demais regalias e privilégio que, diante das leis civis, gozavam as ordens religiosas ${ }^{130}$.

Durante a década de 1960, o já citado Teixeira Soares reforçara a hipótese de que haveria outros fatores, para além dos argumentos de teor pedagógico e filosófico, para a dura retaliação aos jesuítas:

[...] a campanha contra a Companhia de Jesus teria de ser deflagrada em frentes distintas. Dela participariam monarcas, primeiros-ministros, escritores, interessados em desvirtuar a ação dos missionários, apresentando-os como perigosos elementos de atividades antiestatais e lesadores do poder absolutista dos soberanos, porque estavam nos socavões da selva paraguaia criando trabalho e riqueza. Os motivos mais estranhos foram invocados para justificar a campanha ${ }^{131}$.

Um dos estudos mais relevantes sobre as motivações económicas que embalaram a Coroa portuguesa, em suas decisões tomadas na década de 1750, chegou ao Brasil em $1970^{132}$. No capítulo sob sua responsabilidade, o estadunidense Dauril Alden enfatizava a necessidade de se revisar as pesquisas sobre os embates entre o reino e a Ordem da Companhia de Jesus. Segundo o historiador, até ao final do século XVII,

Essas concessões territoriais e dotações representavam a amplitude da assistência econômica direta da Coroa aos jesuítas. Com o correr do tempo, em fins do século XVII pelo menos, a importância dessa ajuda foi em muito ultrapassada pelo nível da

\footnotetext{
130 Laerte Ramos de Carvalho, As reformas pombalinas da instrução pública, São Paulo, Edusp, Edição Saraiva, 1978, p. 41.

${ }^{131}$ Álvaro Teixeira Soares, O Marquês de Pombal, Brasília (DF), Editora UnB, 1983, p. 148.

132 Organizada por Henry Keith e S. F. Edwards, a coletânea Conflict \& continuity in brazilian society foi editada pela University of South Carolina Press em 1969. A contribuição de Dauril Alden é essencial para os estudiosos que levam em conta o apelo dos negócios nas decisões que culminaram na expulsão dos jesuítas, entre 1759 (em Portugal) e 1760 (no Brasil).
} 
beneficência particular e pela quantidade de capital que os jesuítas podiam produzir com o número cada vez maior de suas propriedades ${ }^{133}$.

O trabalho de Alden recupera outra informação ignorada por uma grande parcela de nossos historiadores: o facto de que os renhidos embates entre a Coroa e a Companhia de Jesus tiveram início desde os primeiros tempos da colónia, após a chegada, instalação e expansão dos inacianos no Brasil, em meados do século XVI:

Tais ataques [dos colonos] começaram logo depois que os jesuítas chegaram na colônia. Muito antes de surgirem as questões relacionadas com suas atividades econômicas, os jesuítas opuseram-se aos leigos no tocante ao controle dos índios. Os colonos queriam estes últimos concentrados em aldeias nas proximidades de suas lavouras a fim de os explorar como força de trabalho. Os missionários, desejando proteger os índios contra a exploração e facilitar a iniciação deles nos preceitos do cristianismo, isolavam-nos o mais possível dos colonos e insistiam em servir de intermediários entre os indígenas e os fazendeiros em questões de trabalho e comércio. Nas diretrizes gerais e em legislação especial, a partir de 1570, a Coroa apoiou as tentativas jesuíticas de defender os índios até a década de $1750^{134}$.

De entre os estudos de maior fôlego, cumpre destacar $A$ Universidade temporã, pesquisa em três volumes publicada originalmente em 1980, pelo historiador e educador Luiz Antônio Cunha. Ele também chamava a atenção para os fatores concomitantes que embasaram as medidas tomadas pelo governo português, tendo em vista enfraquecer o poderio económico e a influência cultural dos jesuítas:

[...] na medida em que a política econômica de Pombal buscava a intensificação da produção para o comércio, implicava «libertar» os indígenas dos padres, isto é, torná-los disponíveis para serem integrados à economia como escravos, se não de direito, pelo menos de fato (salário simbólico). Além disso, o ativo comércio que os padres faziam com as drogas do sertão em nada contribuía para o tesouro real, pois eles estavam dispensados do pagamento dos dízimos e dos direitos alfandegários. A criação da Companhia Geral do Grão-Pará e Maranhão, em 1755, foi uma

\footnotetext{
133 Dauril Alden, "Aspectos econômicos da expulsão dos jesuítas do Brasil: notícia preliminar», in Henry H. Keith e S. F. Edwards, Conflito e continuidade na sociedade brasileira - ensaios, trad. José Laurênio de Melo, Rio de Janeiro, Civilização Brasileira, 1970, p. 34.

${ }^{134}$ Idem, Ibidem, pp. 37-38.
} 
tentativa de deslocar o poder econômico dos padres, principalmente dos jesuítas ${ }^{135}$.

Uma das sequelas que persistem nos estudos sobre o período está na visão simplista e rebaixadora dos jesuítas, que impede aos consulentes vislumbrar a complexa e longeva ligação da Companhia de Jesus com o Estado português, bem como sua postura em relação aos índios.

Para José Eduardo Franco, as providências adotadas pela Coroa portuguesa propiciaram a instauração de uma postura antijesuítica, que persiste ainda em nossos dias, em meio aos avanços e recuos ideológicos de cada período histórico. A seu ver, as virtudes dos padres da Ordem da Companhia de Jesus foram tratadas em chave invertida, graças a escusos interesses do Reino português, em meados do século XVIII:

A angariação, pelos Jesuítas, de meios materiais suplementares de sustentação das estruturas e equipas de evangelização ad extra e de educação ad intra foi interpretada sob o signo da cupidez, dada como imprópria, porque inconciliável com o estado de vida religiosa. A larga aposta dos Inacianos na educação foi vista como forma de conquistar influência sobre a sociedade. A sua presença entre as esferas do poder como confessores, técnicos, sábios ou conselheiros, foi lida como o fruto de uma ambição cujo limite não era menos que o universo inteiro. A sua visão optimista do homem, com consequências no aliviar de uma concepção rigorista da moral, foi censurada como laxismo e permissividade ${ }^{136}$.

Resgatemos, a seguir, o papel de algumas figuras que participaram ativamente dos projetos da Coroa para desqualificar e enfraquecer o poderio dos jesuítas, de modo a questionar o desmedido centralismo em torno de Pombal.

\footnotetext{
135 Luiz Antônio Cunha, A universidade temporã: o ensino superior, da Colônia à Era Vargas, 3. a ed., São Paulo, Editora Unesp, 2007, p. 42.

${ }^{136}$ José Eduardo Franco, «O mito dos jesuítas para além do tempo do mito: no período do Estado Novo e do regime democrático», Lusitania Sacra, 2. a série, 16, 2004, p. 412.
} 


\section{Protagonismo?}

Ao examinar a volumosa correspondência mantida entre Francisco Xavier de Mendonça Furtado - irmão de Sebastião José de Carvalho e Melo - e seus contatos em Portugal, Kenneth Maxwell reforçara a tese de que a sugestão de se criar a Companhia Comercial no Grão-Pará e Maranhão partiu do próprio governador ${ }^{137}$ da região Norte:

Ele acreditava que a importação de escravos africanos aliviaria a pressão sobre os colonizadores por escravizar e maltratar a população indígena nativa. Também queria ver mais investimentos na economia amazonense a fim de desenvolver seu potencial de exportação que, segundo ele, uma companhia monopolista poderia fornecer ${ }^{138}$.

Essa informação, corroborada por diversos historiadores, significa que, assim como o Sebastião José, de início:

Também Francisco Xavier de Mendonça Furtado não nutriria quaisquer preconceitos contra os Jesuítas. Em contrapartida, desde o primeiro momento, o governador do Grão-Pará e Maranhão constatou in loco o «alto poder» dos religiosos e, em particular, o da Companhia de Jesus sobre os índios e a sua capacidade para resistirem aos projetos emanados do centro político com base no Regimento das Missões. ${ }^{139}$

137 Isso se verifica em numerosas correspondências enviadas por Francisco Xavier a Sebastião José, a exemplo desta, de 12 de maio de 1755: «Nessas cidades do Pará e Maranhão, é preciso estabelecer a mesma Companhia [de Comércio] e em cada uma delas uma administração composta de pessoas das mesmas boas qualidades» (Marcos Carneiro de Mendonça, A Amazônia na era pombalina - Tomo "I, Brasília (DF), Edições do Senado Federal, 2005[b], p. 359.

138 Kenneth Maxwell, Marquês de Pombal, paradoxo do lluminismo, 2. a ed., trad. Antônio de Pádua Danesi, Rio de Janeiro, Paz e Terra, 1997, p. 59.

139 João Paulo Oliveira Costa et alii, História da expansão e do império português, Lisboa, Esfera dos Livros, 2014, p. 268. De acordo com Manuel Nunes Dias, «A partir de setembro de 1751 [...] tudo começou a mudar. Transferida a capital do Estado para a cidade de Belém, Francisco Xavier de Mendonça Furtado iniciou na colônia uma governança inteiramente concordante com a filosofia política do despotismo pombalino. Os jesuítas fingiam não entender que as aldeias de índios não pertenciam ao seu patrimônio mas, sim, ao da Coroa» (Manuel Nunes Dias, Fomento e mercantilismo: a Companhia do Grão-Pará e Maranhão (1755-1778), Belém, UFPA, 1970, p. 195). 
A personalidade do governador não demorou a se revelar. Joaquim Romero Magalhães assinala a vigorosa atuação de Mendonça Furtado ${ }^{140}$, desde os primeiros dias como governador do Grão-Pará e Maranhão. As providências que Francisco Xavier implementou evidenciam a preocupação maior e imediata do governador, que dialogava com os pressupostos negociais embutidos no discurso vigente:

Ainda mal chegado a Belém, começa o governador a tratar da fazenda real, que andava muito desprezada. E pretende iniciar a cobrança dos dízimos do gado da Ilha de Marajó. Os mercedários teriam entre 60 e 100 mil cabeças de gado vacum; os da Companhia entre 25 e 30 mil; os do Carmo entre 8 e 10 mil. E também constata que as drogas do sertão - nomeadamente o cacau e o cravo - estavam quase todas nas mesmas mãos. Que nada pagavam à fazenda. Como se recusavam a dar índios para o trabalho num engenho real, dos padres da Companhia, a que pede auxílio, recebe uma "formal repulsa». É o primeiro choque com os jesuítas que se detecta ${ }^{141}$.

Enquanto a Coroa aparelhava o Estado, em termos político, financeiro e administrativo, os embates entre o Governo e a Companhia de Jesus ultrapassavam as barreiras tanto espirituais quanto temporais, propagando-se em outras possessões de Portugal no vasto território:

Em todas as regiões de onde foram excluídos, as justificativas eram sempre muito parecidas: os padres inacianos se envolviam demais nos negócios locais, interferiam a favor de sua Ordem em detrimento dos interesses metropolitanos e dos colonos, controlavam os possíveis trabalhadores, enfim, intrometiam-se diretamente nos assuntos temporais, tornando-se cada vez maios opulentos ${ }^{142}$.

\footnotetext{
140 «Essa nomeação estratégica contribuiu para arruinar ainda mais as relações do governo português com os jesuítas. Nesse sentido, torna-se interessante atentar para alguns pontos contidos nas Instruções régias públicas e secretas encaminhadas por D. José I a esse governador. Por meio delas é possível perceber que uma parte do desempenho de suas atividades estava relacionada com os esforços da Coroa em dar maior liberdade aos povos indígenas e ao mesmo tempo em diminuir o poderio dos Eclesiásticos» (Márcia Amantino e Marieta Pinheiro de Carvalho, "Pombal, a riqueza dos jesuítas e a expulsão», in Francisco Falcon e Claudia Rodrigues, $A$ «Época Pombalina» no mundo luso-brasileiro, Rio de Janeiro, FGV Editora, 2015, p. 74).

${ }^{141}$ Joaquim Romero Magalhães, Labirintos brasileiros, São Paulo, Alameda, 2011, p. 212.

142 Márcia Amantino e Marieta Pinheiro de Carvalho, «Pombal, a riqueza dos jesuítas e a expulsão», in Francisco Falcon e Claudia Rodrigues, $A$ «Época Pombalina» no mundo luso-brasileiro, Rio de Janeiro, FGV Editora, 2015, pp. 70-71.
} 
Relativizando-se o protagonismo de Sebastião José ${ }^{143}$, o facto é que a receção ao projeto de seu irmão não poderia ter recebido melhor acolhida - em parte, graças à sabida interferência do braço direito de D. José I:

O ano de $1755^{144}$ foi de charneira nesta conjunta. Os primeiros padres jesuítas foram expulsos do Grão-Pará e Maranhão, na sequência de tentativas de fomentar a revolta contra o governador, e a capitania de São José do Rio Negro foi instituída a 3 de Março. Em Lisboa, foi criada a Junta de Comércio e publicaram-se o alvará de 4 de Abril, incentivando o casamento entre brancos e índios e promovendo a mestiçagem como estratégia de colonização, as leis de 6 e 7 de Junho relativas à liberdade dos índios, que prepararam o terreno para o Directório ${ }^{145}$, e os estatutos da Companhia Geral do Grão-Pará e Maranhão, legislação que, com muita probabilidade, teve na sua génese a visão de Francisco Xavier ${ }^{146}$.

Por outro lado, se muitas dentre as ações de Sebastião José se respaldavam nos relatos de seu irmão, instalado no Pará durante a década de 1750, deve-se lembrar que os pilares da argumentação de Francisco Xavier dialogavam com os numerosos e extensos memoriais legados por Paulo da Silva Nunes - um modesto soldado que circulou no Estado do Grão-Pará e

\footnotetext{
${ }^{143}$ Lê-se no Dicionário do Brasil Colonial que os irmãos teriam agido em consonância, conforme a "política do governador do Grão-Pará e Maranhão, Francisco Xavier de Mendonça Furtado, de converter os nativos em vassalos livres da Coroa e reassumir o controle temporal sobre as aldeias indígenas, política definida por seu irmão, o poderoso marquês de Pombal» (Ronaldo Vainfas (dir.), Dicionário do Brasil Colonial (1500-1808), Rio de Janeiro, Objetiva, 2000, p. 328).

${ }^{144} \mathrm{Em} \mathrm{1757,} \mathrm{continuava} \mathrm{intensa} \mathrm{a} \mathrm{correspondência} \mathrm{entre} \mathrm{os} \mathrm{irmãos} \mathrm{Francisco} \mathrm{Xavier} \mathrm{e} \mathrm{Sebastião} \mathrm{José.} \mathrm{A}$ maior parte de seus argumentos reiteravam o que vinha sido declarado desde 1751, a exemplo desta carta de 25 de abril daquele ano, assinada pelo governador: «[...] estes padres [jesuítas] não perdem de vista a ideia que formaram, sem mais objeto que o arruinarem por esta forma, inteiramente, os novos e importantes estabelecimentos a que se está dando princípio; querendo conservar o grosso comércio que estavam fazendo e o alto e absoluto poder que tinham sobre todos estes povos» (Marcos Carneiro de Mendonça, A Amazônia na era pombalina - Tomo III, Brasília (DF), Edições do Senado Federal, 2005[c], p. 233).

${ }^{145}$ «Apesar de inicialmente ter sido elaborada para atender as conjunturas específicas do Estado do GrãoPará e Maranhão, dois anos depois de promulgada, a Lei do Diretório foi estendida ao Estado do Brasil. Previa a secularização da administração das aldeias por meio da troca dos missionários regulares por funcionários civis e militares, cabendo aos religiosos apenas as atividades missionárias; a obrigatoriedade do ensino do português para que todos pudessem se comunicar com os índios e estes com os demais membros da sociedade, acabando, assim, com o poder de intermediários dos jesuítas; e, principalmente, o estímulo aos casamentos entre índios e brancos para a criação de uma sociedade capaz de ocupar, povoar e desenvolver as economias locais» (Márcia Amantino e Marieta Pinheiro de Carvalho, «Pombal, a riqueza dos jesuítas e a expulsão», in Francisco Falcon e Claudia Rodrigues, $A$ «Época Pombalina» no mundo luso-brasileiro, Rio de Janeiro, FGV Editora, 2015, p. 80).

${ }^{146}$ João Paulo Oliveira Costa et alii, História da expansão e do império português, Lisboa, Esfera dos Livros, 2014, p. 270.
} 
Maranhão entre 1702 e 1720, e que, graças a suas relações com o alto escalão reinol, chegou a governar duas modestas cidades à beira do Amazonas (Alden, 1970).

Como Nunes acompanhara de perto diversas expedições fiscalizatórias às aldeias indígenas, passou a redigir relatos de caráter oficial, destinados à Corte. Apesar de praticamente desconsiderados a princípio, sua persistência em enviar tais documentos à Coroa não foi em vão, especialmente quando levou um longo memorial à Lisboa, após sua prisão na colónia. Não será coincidência que, em suas denúncias, ele apontasse ressalvas, redivivas 30 anos depois, por Mendonça Furtado:

[...] [Silva Nunes] defendia os colonos e atacava os jesuítas por terem neutralizado as diretrizes da Coroa concernentes ao suprimento de trabalhadores indígenas para os fazendeiros, por se terem transformado em senhores absolutos dos aborígenes, e por engajarem-se no comércio de especiarias amazônicas em prejuízo do tesouro real ${ }^{147}$.

À época do governador Francisco Xavier (1751-1759) ${ }^{148}$, um dado fundamental residia nos métodos empregados pela administração central para sanar as dívidas e fortalecer a economia local. Diante das graves dificuldades económicas enfrentadas pelo governador, a Companhia do Grão-Pará e Maranhão funcionou como uma associação de homens mais poderosos do Estado, mas contou também com subsídios da matriz Portugal:

Cada lavrador interessado concorreu com a sua parte para a realização do capital social da projetada Companhia de Comércio e Navegação. Com isso angariou-se a modesta quantia de 32 mil cruzados, fundo que «é insignificante, para um objeto tão grande». Era, com efeito, o melancólico testemunho da miséria da colônia. Temeroso de um possível esmorecimento da parte dos lavradores do Pará e Maranhão, Mendonça Furtado recorreu para a poupança do reino ${ }^{149}$.

\footnotetext{
147 Dauril Alden, "Aspectos econômicos da expulsão dos jesuítas do Brasil: notícia preliminar», in Henry H. Keith e S. F. Edwards, Conflito e continuidade na sociedade brasileira - ensaios, trad. José Laurênio de Melo, Rio de Janeiro, Civilização Brasileira, 1970, p. 44.

148 «Mendonça Furtado saíra vitorioso onde o infatigável Paulo da Silva Nunes tinha fracassado: levara a Coroa a crer que as atividades comerciais dos jesuítas punham em grave perigo as possibilidades do desenvolvimento econômico do Brasil setentrional e privavam o rei de vastas receitas» (Dauril Alden, "Aspectos econômicos da expulsão dos jesuítas do Brasil: notícia preliminar», in Henry H. Keith e S. F. Edwards, Conflito e continuidade na sociedade brasileira - ensaios, trad. José Laurênio de Melo, Rio de Janeiro, Civilização Brasileira, 1970, p. 60).

${ }^{149}$ Manuel Nunes Dias, Fomento e mercantilismo: a Companhia do Grão-Pará e Maranhão (1755-1778), Belém, UFPA, 1970, pp. 200-201.
} 
Associado à revitalização do Estado, outro lugar-comum, percebido na Historiografia, reside na estreita vinculação da reforma pedagógica em Portugal (centrada nos novos estatutos da Universidade de Coimbra na década de 1770) ao nome de Sebastião José de Carvalho e Melo. Deve-se lembrar que ele não foi o primeiro estadista a tratar do assunto, que vinha sendo estudado desde o reinado de Dom João V, entre 1707 e 1750.

Do ponto de vista cultural, Pombal não foi pioneiro em sua atuação como pródigo mecenas, ao proteger e financiar artistas que faziam propaganda do governo e de sua imagem. Sabe-se que, durante o reinado de Dom João V, a fundação da Real Academia Portuguesa de História, em 1720, deu grande impulso para que o rei incentivasse as viagens de portugueses interessados em recolher informações de outros países da Europa. Eram os célebres "estrangeirados», que antecipavam em décadas a atuação de Sebastião José nas cortes de Londres e Viena. De acordo com José Ferreira Carrato:

Os «estrangeirados» eram portugueses inteligentes que viajavam para o estrangeiro, onde viam, observavam, estudavam e acabavam adotando as ideias iluministas. Eram diplomatas, eclesiásticos, cientistas e políticos que, após permanecerem ou estudarem nos centros mais adiantados da Europa, traziam de volta à terra natal - uma terra geográfica e culturalmente de costas voltadas para o continente - o fermento renovador. $O$ próprio $D$. João $V$ - que, tão logo passa a dispor a mancheias dos ouros e dos diamantes do Brasil, adquire o título bajulatório de "Magnânimo» - favorece a vinda ao Reino de estrangeiros ilustres e a viagem ao exterior de portugueses de futuro, e funda em Roma, para acolhê-los, a Academia de Portugal, com bolsas de estudos, ajudas de custos, etc. ${ }^{150}$.

Portanto, é digno de nota que os manuais de História concedam maior destaque ao mecenato de Pombal - implementado somente ao final de sua vida -, que às iniciativas prévias de $D$. João $V$, adotadas muito antes do reinado de seu filho $D$. José I - monarca supostamente mais «apagado», que teria vivido à sombra de seu «todo-poderoso» primeiro-ministro.

Como se está a falar em protagonistas, deve-se destacar a figura do cientista e médico José de Castro Sarmento (1691-1762), em meio às novas orientações do ensino sedimentadas

150 José Ferreira Carrato, O lluminismo em Portugal e as reformas pombalinas do ensino, São Paulo, Faculdade de Filosofia, Letras e Ciências Humanas da Universidade de São Paulo (Série Didática), 1980, p. 15. 
durante a Reforma da Universidade de Coimbra em 1772. Na década de 1730, ele passou a viver na Inglaterra e disseminou as ideias de Newton, traduzindo-as para português.

É ao próprio Sarmento que se atribui a primeira grande reforma na carreira de Medicina, transferida por ele ao rei $D$. João $V$. Afora isso, o médico dialogou vivamente com dois protagonistas de seu tempo, tendo em vista dar continuidade ao seu projeto educacional:

[José de Castro Sarmento] instrui o rei D. João V sobre a necessidade de reformar o ensino da medicina em Coimbra, manda para a Universidade seu primeiro microscópio, agencia-lhe a compra de equipamentos científicos e, após ter feito a apologia da experimentação numa tradução de Estêvão Halles (Relação de Alguns Experimentos..., Londres, 1742), dedica-se significativamente a um homem público que começa a sobressair-se em 1738, chamado Sebastião José de Carvalho e Melo; e ainda os irmãos Alexandre e Bartolomeu Lourenço de Gusmão, idos do Brasil doutorar-se em Coimbra ${ }^{151}$.

Apoiado na contribuição de diversos estudiosos da História de Portugal, a pesquisa de Carrato deixa clara a necessidade de se relativizar a proeminência do Marquês de Pombal em diversas matérias a que se the atribui a primazia. Isso é revelador, considerando que o referido historiador percebia a figura do ministro com manifesta simpatia ${ }^{152}$.

Examinemos alguns dentre os procedimentos tocados pelo Estado português, após a expulsão dos jesuítas.

\section{Reforma?}

Um dos argumentos mais recorrentes, encontrados nos estudos sobre o lluminismo português, reside nas sensíveis diferenças percebidas quando se compara o que se sucedeu naquele país com o que se dava especialmente na França. Mário Júlio de Almeida Costa sintetizou tais ingredientes sob o viés do Direito e o influxo da religião:

\footnotetext{
151 Idem, Ibidem, p. 12.

152 «[...] nossa homenagem ao Marquês de Pombal, o grande renovador da moderna cultura portuguesa, caído do poder com a ascensão da rainha D. Maria I» (Idem, Ibidem, p. 5).
} 
Sinais peculiares apresentou o lluminismo nos países marcadamente católicos, como a Espanha e Portugal, mas tendo como centro de irradiação a Itália. Também aqui se registaram as influências do racionalismo e da filosofia moderna, assistindose à renovação da atividade científica, a inovações pedagógicas, a certa difusão do espírito laico, à reforma das instituições sociais e políticas. De qualquer modo, o reformismo e o pedagogismo não tiveram um caráter revolucionário, anti-histórico e irreligioso, idêntico ao apresentado em França ${ }^{153}$.

As «peculiaridades» da llustração portuguesa, a que se refere Costa, costumam ser aventadas por diversos historiadores. Atento ao tom categórico e à reprodução de lugarescomuns por uma parte dos pesquisadores, Luiz Eduardo Oliveira tem relativizado afirmações dessa natureza. A seu ver:

O senso comum generalizado é o de que o iluminismo português foi incompleto ou imperfeito. Alguns historiadores consideram-no até canhestro, dado o grau de atraso de Portugal em relação às grandes nações europeias [...] Uma consequência incontornável desse tipo de perspectiva é que o estudo da legislação pombalina, por exemplo, só pode ser realizado em termos de defasagem ou atraso em relação a uma modernidade europeia ${ }^{154}$.

Há que se lembrar que a forte rutura, usualmente atribuída aos atos oficiais assinados por Sebastião José, precisaria ser posta em questão. Kenneth Maxwell observou que a relação entre o Estado português e a Igreja precisa ser re-examinada, sob pena de nos esquecermos do forte componente religioso embutido nas decisões reais, especialmente durante o reinado do devoto D. José I:

Os padres também tiveram um papel importante na introdução de novas ideias. Ao contrário do Norte da Europa, onde os proponentes da filosofia racionalista e da experimentação científica «moderna» tornaram-se críticos acerbos da Igreja e da

153 Mário Júlio de Almeida Costa, História do Direito português, 3.a ed., 4. reimp., Coimbra, Livraria Almedina, 2002, p. 361.

154 Luiz Eduardo Oliveira, "A invenção da tradição e o mito da modernidade: aspectos principais da legislação pombalina sobre o ensino de línguas», in Luiz Eduardo Oliveira (dir.), A legislação pombalina sobre o ensino de línguas: suas implicações na educação brasileira (1757-1827), Maceió, Edufal, 2010, pp. 19-20. 
religião, em Portugal alguns dos mais francos defensores (e também profissionais) da reforma educacional saíram da instituição religiosa ${ }^{155}$.

Não se tratava de mera disputa filosófica ou contenda metafísica entre a Coroa e a Igreja, mas de uma acirrada batalha política ${ }^{156}$ pelo poderio e bens ${ }^{157}$ do território na colónia compreendidos os produtos comercializados, a isenção de taxas e impostos, a manutenção de gado, a utilização de plantas e drogas regionais e, claro, a filiação dos índios, não à Companhia de Jesus, mas à Cora, pela vassalagem ${ }^{158}$. Isso dizia respeito ao pacto de sujeição ${ }^{159}$ impingido pelo reino. A reação dos inacianos não poderia ser outra:

A alguma medida régia ou disposição governamental que lhes não convinha os jesuítas respondiam atuando na corte para a infletir ou fazer com que se não executasse. Mas ainda nisso a Companhia se equivocara. Os jesuítas, detentores de verdades eternas, de políticas que eram as seguras porque aprovadas pela Companhia para maior glória de Deus não perceberam que os tempos eram outros, que ao regalismo josefino não conseguiriam escapar-se por mais habilidades que usassem. A glória de Deus passara a estar subordinada à vontade do rei ${ }^{160}$.

155 Kenneth Maxwell, Marquês de Pombal, paradoxo do lluminismo, 2. a ed., trad. Antônio de Pádua Danesi, Rio de Janeiro, Paz e Terra, 1997, p. 13.

156 «Nesta grande etapa da história do antijesuitismo, os protagonistas do combate à Companhia inscreviam-se, em geral, religiosamente no universo do catolicismo e politicamente no âmbito da monarquia. A propaganda antijesuítica que conduziu à formação pombalina do mito decorreu de um trabalho concertado entre eclesiásticos e políticos que permitiu a operacionalização eficaz dos seus objectivos. Portanto, assim o mito jesuíta nasceu no seio da sociedade católica e foi engendrado por católicos» (José Eduardo Franco, "O mito dos jesuítas para além do tempo do mito: no período do Estado Novo e do regime democrático», Lusitania Sacra, 2. série, 16, 2004, p. 414).

157 «O anti-jesuitismo do discurso da legislação pombalina tem um caráter muito mais político e econômico do que ideológico, pois a Companhia de Jesus representava um obstáculo para a implementação e desenvolvimento das novas diretrizes da administração colonial, que, por sua vez, busca a todo custo colocar o Estado português em condições políticas e econômicas que lhe permitissem competir com as demais nações europeias» (Luiz Eduardo Oliveira, "A invenção da tradição e o mito da modernidade: aspectos principais da legislação pombalina sobre o ensino de línguas», in Luiz Eduardo Oliveira (dir.), A legislação pombalina sobre o ensino de línguas: suas implicações na educação brasileira (1757-1827), Maceió, Edufal, 2010, p. 27).

${ }_{158}$ Perguntava-se Paulo da Silva Nunes: «Se os etíopes podem ser feitos cativos, por que não os índios do Maranhão?» (Dauril Alden, "Aspectos econômicos da expulsão dos jesuítas do Brasil: notícia preliminar», in Henry H. Keith e S. F. Edwards, Conflito e continuidade na sociedade brasileira - ensaios, trad. José Laurênio de Melo, Rio de Janeiro, Civilização Brasileira, 1970, p. 45).

${ }^{159}$ Curiosamente, atribui-se ao jesuíta espanhol Francisco Suárez (1548-1617) as conceções de pactum associationis (pacto de associação) e pactum subjectiones (pacto de sujeição). $\mathrm{O}$ "pacto de associação» subentende a distribuição do consórcio político entre pares sociais. Já o «pacto de sujeição» se atribuiria a uma autoridade de poder soberano e absoluto (Cf. Pedro Calafate, "A ideia de soberania em Francisco Suárez», in Adelino Cardoso et al. (dir.) Francisco Suárez (1548-1617), tradição e modernidade, Lisboa, Edições Colibri/Centro de Filosofia da Universidade de Lisboa, 1999, p. 251 e ss.).

160 Joaquim Romero Magalhães, Labirintos brasileiros, São Paulo, Alameda, 2011, p. 220). 
Há um fator específico a considerar, tendo em vista o processo de substituição dos jesuítas por tutores subsidiados pelo Estado português, no ensino. É que essa mudança constitui uma das descontinuidades relacionadas à destituição dos membros da ordem religiosa mais poderosa da colónia. Como registara João Ameal, na década de 1940:

A eliminação da Companhia de Jesus deixa um vazio imenso no campo da inteligência e do ensino. Pretende-se substituí-la dentro de um critério diametralmente oposto. Sempre o mesmo lema: imolar os jesuítas aos enciclopedistas. Os novos professores divulgam a filosofia das luzes, usam os seus métodos simplistas e ambiciosos. Se alguma coisa útil se faz para desenvolvimento dos estudos, a maior parte das iniciativas ressente-se do vício de origem ${ }^{161}$.

Dessa maneira, uma das consequências imediatas da reforma do ensino, em tese capitaneada por Sebastião José, é que ela influiu decisivamente na renovada ênfase concedida aos estudos de Retórica, desta vez voltada não para os exercícios pedagógicos de fins religiosos, mas no âmbito da composição literária.

Como o assunto envolvia as belas letras, é sintomático que as Academias francesas e italianas ${ }^{162}$ se tenham ramificado por espelhamento tanto em Portugal quanto no Brasil, durante o período. No que tocava às novas diretrizes do ensino, Aníbal Pinto de Castro reparou que:

[...] apesar da orientação deliberadamente prática e experimentalista que a caracterizava, a reforma dos estudos menores ordenada em 1759 pelo Marquês de Pombal, quando da reorganização do sistema pedagógico nacional, após a expulsão da Companhia de Jesus, concede à Retórica um lugar preponderante no quadro das disciplinas humanísticas. $O$ antijesuitismo do ministro de $D$. José I dava-se pressa em aproveitar a ideia então corrente, e em boa parte injusta, de que a responsabilidade da decadência do bom gosto literário cabia em exclusivo ao método pedagógico suprido nas escolas da Companhia, para ordenar a restauração

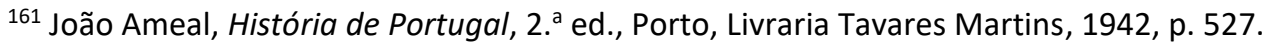

162 «Também em Portugal terão muita importância na pregação iluminista os movimentos culturais representados especialmente pelas Academias. Foram os Restauradores e o clero os implantadores da primeira delas, a dos Generosos, que teve funcionamento regular entre 1647 e 1667 e, depois, em 16856. Após alguma interrupção, entre 1696 e 1717 passou a funcionar na livraria do Conde de Ericeira (16731743) a nova Academia das Conferências Discretas e Eruditas, já entrando pelos primeiros anos do reinado do rei D. João V. E foi o jovem monarca quem acabou por tornar realidade os sonhos mais ambiciosos do Conde de Ericeira, criando finalmente, em 8 de dezembro de 1720, a Academia Real da História» (José Ferreira Carrato, O lluminismo em Portugal e as reformas pombalinas do ensino, São Paulo, Faculdade de Filosofia, Letras e Ciências Humanas da Universidade de São Paulo (Série Didática), 1980, pp. 10-11 - grifo nosso).
} 
do sistema quinhentista, que tanto brilho alcançara, agora sujeito à necessária simplificação e modernização ${ }^{163}$.

Combinada à ideia de civilização generalizada, a «tutela» do Estado exercida sobre os índios revelava as escusas intenções das autoridades reinóis. Em ofício datado em 21 de maio de $1757^{164}$, o próprio governador Francisco Xavier de Mendonça Furtado se referia aos nativos nos seguintes termos: «as piíssimas intenções de Sua Majestade ficariam frustradas, se absolutamente se entregasse a estes miseráveis e rústicos ignorantes o governo absoluto da quantidade de povoações, que constituem este grande Estado» ${ }^{165}$.

De um lado, defender a reforma do ensino oficial, reservado ao homem branco, preferencialmente de matriz lusitana e sediado na corte; de outro, asseverar a manutenção da precária «liberdade» indígena, a reiterar o antigo pressuposto de que os nativos se encontrariam em estágio cultural menos avançado que o de seus colonizadores. Para isso, eles precisavam ser civilizados e integrados ao reino, de modo a se tornarem peças úteis na povoação dos territórios, na expansão da fé e no incremento dos negócios. Havia que se renovar as premissas, firmadas pelo Concílio de Trento, de que sua alma estivesse desencaminhada e de que eles pertenciam ao Corpo Místico ${ }^{166}$ - este, consubstanciado na figura sagrada do rei, mancomunado com o poderoso Vaticano.

\section{Considerações Finais}

Sem negar os fatores culturais e pedagógicos que lhe foram inerentes, o lluminismo português não pode ser dissociado dos pressupostos económicos que o presidiram. Sinal disso

\footnotetext{
${ }^{163}$ Aníbal Pinto de Castro, Retórica e teorização literária em Portugal: do Humanismo ao Neoclassicismo, 2.a ed., Lisboa, Imprensa Nacional - Casa da Moeda, 2008, pp. 587-588).

${ }^{164}$ Não por acaso, Mendonça Furtado utilizou verbos de conotação quase religiosa, arrogando a si mesmo a persistente e inglória tarefa de libertar os índios, desde sua chegada ao Estado do Grão-Pará e Maranhão, em 1751. Em correspondência ao Secretário e Marinha e Ultramar Tomé Joaquim da Costa Corte-Real, o governador manifestava a «[...] certeza de que já não fazia novidade o falar-se em índios livres, depois de eu estar pregando a estes povos 6 anos» (Marcos Carneiro de Mendonça, A Amazônia na era pombalina - Tomo III, Brasília (DF), Edições do Senado Federal, 2005c, p. 293 - grifo nosso).

${ }^{165}$ Furtado apud João Lúcio de Azevedo, Os jesuitas no Grão-Pará: suas missões e a colonização - bosquejo histórico com vários documentos inéditos, Lisboa, Tavares Cardoso \& Irmão, 1901, p. 286.

166 Durante séculos, enquanto o Papa usava uma coroa dourada além de sua tiara, o rei mantinha uma mitra debaixo de sua coroa (Cf. Ernst H. Kantorowicz, The King's Two Bodies: a Study in Mediaeval Political Theology, New Jersey, Princeton University Press, 1997, pp. 193-272).
} 
é o facto de o então diplomata Sebastião José de Carvalho e Melo ter frequentado durante anos a corte inglesa (1738-1744), país berço da Revolução Industrial.

É ponto pacífico, entre os historiadores, que desde sua estadia em Londres, o futuro secretário Sebastião José cogitava maneiras de reproduzir nas colónias portuguesas diversas iniciativas de caráter protecionista, inspiradas naquele poderoso país, com sutileza necessária para não romper os tratados firmados entre os reinos.

A análise do libelo de 1757, atribuído a Sebastião José (A república jesuítica ultramarina), combinada aos estudos preexistentes das Instruções e leis promulgadas por D. José I, bem como ao exame das correspondências ativas e passivas de Francisco Xavier de Mendonça Furtado - governador do Estado do Grão-Pará, entre 1751 e 1759 - sinaliza que se dê maior atenção às orientações económicas e administrativas que nortearam as ações adotadas pelo reino contra a Ordem da Companhia de Jesus, intensificadas a partir de 1755.

Valiosos estudos, realizados desde o início do século xx, permitem-nos rever a conceção tradicional sobre determinados capítulos da história luso-brasileira - em parte, animada pelo Positivismo pintado com as cores nacionalistas, durante Oitocentos, e somada a uma abordagem superficial que contagiou boa parte de nossos historiadores, cujos efeitos se fazem sentir ainda hoje.

Causa estranheza que em diversos manuais do ensino médio a figura de Pombal ainda paire solitária e soberana, aos mandos e desmandos da burocrática e tentacular corte portuguesa - sem contar outros poderosos e lídimos representantes do Reino, em sua forte intervenção nos Estados do Brasil e do Grão-Pará e Maranhão.

Nesse quesito em particular, a avaliação de diversas obras de cunho didático tem validado a hipótese de que a concisão dos capítulos e a lacuna das informações favorece a cristalização de uma imagem personalista de Pombal, que the confere univocidade ao atuar como principal legislador e executor de variadas leis, instruções e reformas (implementadas tanto em Portugal quanto em seus domínios).

Talvez por enaltecer em demasia a figura de Sebastião José, diversos historiadores subestimem o poder do próprio rei (que o nomeou), além de governantes (a exemplo do próprio irmão de Carvalho e Melo), bem como bispos, padres oratorianos e numerosos funcionários da corte que tiveram atuação decisiva junto à Coroa. Essa conceção personalista leva a desconsiderar o longo alcance e as múltiplas funções do Estado, articulado à poderosa Igreja católica, durante os eventos ligados à controversa expulsão dos jesuítas. 
Atribuir um protagonismo quase absoluto a Pombal é atitude que mereceria ser discutida. Bastaria recordar a complexa jurisprudência e a morosidade dos protocolos que subsidiavam as decisões, autorizadas ou não pela Coroa. Elas tramitavam sob os muitos olhos e ouvidos de minuciosos diplomatas, ouvidores, secretários, fiscais, dentre tantos outros súditos. A exemplo de Pombal, eles estavam rigorosamente subordinados à «vontade e desejo real», expressos por D. José I nos documentos que assinou ao longo de 27 anos. 


\section{Referências bibliográficas}

A. Souto Maior, História do Brasil, 5. ed., São Paulo, Companhia Editora Nacional, 1967. Álvaro Teixeira Soares, O Marquês de Pombal, Brasília (DF), Editora UnB, 1983.

Angela Vianna Botelho e Liana Maria Reis, Dicionário histórico Brasil - Colônia e Império, 3. - ed, Belo Horizonte, Autêntica, 2002.

Aníbal Pinto de Castro, Retórica e teorização literária em Portugal: do Humanismo ao Neoclassicismo, 2. ed., Lisboa, Imprensa Nacional - Casa da Moeda, 2008.

Antonio Carlos do Amaral Azevedo, Dicionário de nomes, termos e conceitos históricos, 2. a ed. Rio de Janeiro, Editora Nova Fronteira, 1997.

Boris Fausto, História concisa do Brasil, São Paulo, Edusp, 2001.

Boris Fausto, História do Brasil, São Paulo, Edusp, 2004.

Charles Boxer, A igreja militante e a expansão ibérica: 1440-1770, trad. Vera Maria Pereira, São Paulo, Companhia das Letras, 2007.

Dauril Alden, "Aspectos econômicos da expulsão dos jesuítas do Brasil: notícia preliminar", in Henry H. Keith e S. F. Edwards, Conflito e continuidade na sociedade brasileira - ensaios, trad. José Laurênio de Melo, Rio de Janeiro, Civilização Brasileira, 1970, p. 31-78.

Denis Diderot e Jean Le Rond D'Alembert, "Discours Préliminaire des Editeurs», Enciclopédia, ou Dicionário razoado das ciências, das artes e dos ofícios, trad. Fúlvia Moretto e Flavia das Graças de Souza, São Paulo, Editora Unesp, 2015.

Domingos Mascarenhas, Portugalidade, biografia duma nação, Lisboa: Edições FP, 1982.

Ernst H. Kantorowicz, The King's Two Bodies: a Study in Mediaeval Political Theology, New Jersey, Princeton University Press, 1997.

Francisco Maria Pires Teixeira, História concisa do Brasil, São Paulo, Global, 1993.

Hélio Vianna, História do Brasil - Vol. 1, 3ª ed., São Paulo, Melhoramentos, 1965.

Heloisa Reichel, "10 de fevereiro de 1756 - Guerra dos Sete Povos das Missões», in Circe Bittencourt (dir.), Dicionário de datas da história do Brasil, 2. a ed., São Paulo, Contexto, 2012, pp. 47-50.

João Ameal, História de Portugal, 2. ${ }^{a}$ ed., Porto, Livraria Tavares Martins, 1942. 
João Lúcio de Azevedo, Os jesuítas no Grão-Pará: suas missões e a colonização bosquejo histórico com vários documentos inéditos, Lisboa, Tavares Cardoso \& Irmão, 1901.

João Paulo Oliveira Costa et alii, História da expansão e do império português, Lisboa, Esfera dos Livros, 2014.

Joaquim Manuel de Macedo, Lições de História do Brasil - para uso das escolas de instrução primária, Rio de Janeiro, Garnier, 1905.

Joaquim Romero Magalhães, Labirintos brasileiros, São Paulo, Alameda, 2011.

Jorge Caldeira et al., Viagem pela história do Brasil, São Paulo, Companhia das Letras, 1997.

José Alves de Freitas Neto e Célio Ricardo Tasinafo, História geral e do Brasil, São Paulo, Harbra, 2006.

José Carlos de Macedo Soares, Fronteiras do Brasil no Regime Colonial, Rio de Janeiro, Livraria José Olympio, 1939.

José Eduardo Franco, "O mito dos jesuítas para além do tempo do mito: no período do Estado Novo e do regime democrático», Lusitania Sacra, 2. a série, 16, 2004, pp. 411430.

José Ferreira Carrato, O Iluminismo em Portugal e as reformas pombalinas do ensino, São Paulo, Faculdade de Filosofia, Letras e Ciências Humanas da Universidade de São Paulo (Série Didática), 1980.

Kenneth Maxwell, Marquês de Pombal, paradoxo do lluminismo, 2. a ed., trad. Antônio de Pádua Danesi, Rio de Janeiro, Paz e Terra, 1997.

Laerte Ramos de Carvalho, As reformas pombalinas da instrução pública, São Paulo, Edusp, Edição Saraiva, 1978.

Luiz Antônio Cunha, A universidade temporã: o ensino superior, da Colônia à Era Vargas, 3. ed., São Paulo, Editora Unesp, 2007.

Luiz Eduardo Oliveira, "A invenção da tradição e o mito da modernidade: aspectos principais da legislação pombalina sobre o ensino de línguas», in Luiz Eduardo Oliveira (dir.), A legislação pombalina sobre o ensino de línguas: suas implicações na educação brasileira (1757-1827), Maceió, Edufal, 2010, pp. 13-48.

Manoel Bomfim, O Brasil na história: deturpação das tradições, degradação politica, Rio de Janeiro, Topbooks, 2013. 
Manuel Nunes Dias, Fomento e mercantilismo: a Companhia do Grão-Pará e Maranhão (1755-1778), Belém, UFPA, 1970.

Márcia Amantino e Marieta Pinheiro de Carvalho, «Pombal, a riqueza dos jesuítas e a expulsão», in Francisco Falcon e Claudia Rodrigues, $A$ "Época Pombalina» no mundo luso-brasileiro, Rio de Janeiro, FGV Editora, 2015, pp. 59-90.

Marcos Carneiro de Mendonça, A Amazônia na era pombalina - Tomo I, Brasília (DF), Edições do Senado Federal, 2005[a].

Marcos Carneiro de Mendonça, A Amazônia na era pombalina - Tomo II, Brasília (DF), Edições do Senado Federal, 2005[b].

Marcos Carneiro de Mendonça, A Amazônia na era pombalina - Tomo III, Brasília (DF), Edições do Senado Federal, 2005[c].

Mário Júlio de Almeida Costa, História do Direito português, 3. ed., 4. a reimp., Coimbra, Livraria Almedina, 2002.

Mary del Priore e Renato Venancio, Uma breve história do Brasil, São Paulo, Planeta, 2010.

Mauro Cezar Coelho, "A construção de uma lei: o diretório dos índios», in Revista do Instituto Histórico e Geográfico Brasileiro, ano 168, n.․ 437, 2007, pp. 29-48.

Paulo de Assunção, Os jesuítas no Brasil colonial, São Paulo, Atual, 2003.

Pedro Calafate, "A ideia de soberania em Francisco Suárez», in Adelino Cardoso et al. (dir.) Francisco Suárez (1548-1617), tradição e modernidade, Lisboa, Edições Colibri/Centro de Filosofia da Universidade de Lisboa, 1999, pp. 251-264.

Ronaldo Vainfas (dir.), Dicionário do Brasil Colonial (1500-1808), Rio de Janeiro, Objetiva, 2000.

Sebastião José de Carvalho e Melo, República jesuítica ultramarina, Gravataí, SMEC; Porto Alegre, Martins Livreiro; Santo Ângelo, Centro de Cultura Missioneira/FUNDAMES, 1989.

Sérgio Buarque de Holanda, História geral da civilização brasileira, Tomo 1, $2^{\circ}$ Volume, Rio de Janeiro, Bertrand Brasil 1997. 


\section{Retrato de Anarda ou a lira aguda de Manuel Botelho de Oliveira}

Se eu podesse desamar/a quen me sempre desamou

(Pero da Ponte, Séc. XIII) ${ }^{167}$

Trovomni Amor del tutto disarmato

(Francesco Petrarca, Séc. XIV) $)^{168}$

Que quanto mais vos pago, mais vos devo

(Luís Vaz de Camões, Séc. XVI) ${ }^{169}$

Resumo: Publicada pela primeira vez em 1705, Música do parnaso foi reeditada apenas no século XX. Este hiato de tempo dificultou o acesso dos leitores e parece vincular-se a uma concepção de literatura nacionalista, que passou a vigorar no final do século XVIII e foi intensificada durante o nosso Romantismo. Neste trabalho, propõe-se a análise de algumas liras de Manuel Botelho de Oliveira, considerando aspectos relacionados à poética seiscentista.

Palavras-chave: Manuel Botelho de Oliveira; Música do Parnaso; Poética.

Abstract: Música do parnaso was published in 1705 and it was reissued in the twentieth century only. This hiatus brings difficulties to the access from the readers and seems to be linked to a nationalist literature conception, on the late eighteenth century, that was intensified during the brazilian Romanticism. In this work we propose to analysis some Manuel Botelho de Oliveira's poems, considering aspects related to the seventeenth-century's poetic.

Keywords: Manuel Botelho de Oliveira; Música do Parnaso; Poetic.

\section{Resgate}

Apesar da qualidade inconteste dos sonetos de Manuel Botelho de Oliveira (1636-1711), durante muito tempo seu nome foi quase totalmente esquecido, tanto por parte dos historiadores quanto por uma considerável parcela dentre os críticos literários e, por irradição, dos manuais voltados ao ensino médio - muitos deles concebidos em prol da indústria facilitadora do vestibular -, que vivem a reproduzir mais do mesmo. Sob essa ótica, é algo sintomático que Música do Parnaso tenha sido reeditado somente no século XX, mais de duas centúrias após a primeira edição do livro, em 1705, pelas mãos do impressor português Miguel Manescal. No estudo introdutório que faz a Fênix renascida (editada entre 1716 e 1728) e a Postilhão de Apolo (coleção de poemas publicada em 1762), João Adolfo Hansen sugere que a depreciação dos poetas

\footnotetext{
167 (Se eu podesse desamar) In: Lênia Márcia Mongelli, Fremosos cantares, 2009, p. 19.

168 (Soneto III) In: Cancioneiro [Canzoniere], 2014, p. 40.

169 (Quem vê, Senhora, claro e manifesto) In: Lírica, 1963, p. 108.
} 
etiquetados como "barrocos", a que Manuel Botelho de Oliveira foi viva e implacavelmente associado, teve origens ainda no século XVIII. O crítico observou que:

Em Portugal, a obra dos seiscentistas começou a ser desqualificada principalmente a partir das reformas da cultura patrocinadas por Sebastião de Carvalho e Melo, Marquês de Pombal. As reformas combatiam o aristotelismo das instituições de ensino controladas pelos jesuítas e as letras do século XVII foram então associadas ao "doloso systema de ignorancia artificial" (HANSEN, 2002, p. 22).

Adma Fadul Muhana (2005) e Ivan Teixeira corroboraram a hipótese de Hansen ao detectar, em nossa "crítica tradicional", a permanência de "pressupostos românticonacionalistas, a desprestigiar a poesia de Botelho de Oliveira, sob pretexto de que lhe faltam singularidade expressiva e integração com a realidade do país", como seria o caso de "Joaquim Norberto de Sousa Silva [Bosquejo da História da poesia brasileira], Cônego Fernandes Pinheiro [Resumo de História Literária], Sílvio Romero [História da literatura brasileira], José Veríssimo [História da literatura brasileira: de Bento Teixeira (1601) a Machado de Assis (1908)] e Ronald de Carvalho [Pequena história da literatura brasileira], entre outros" (TEIXEIRA, 2005, p. 33-34).

Dito de modo mais rasteiro, Manuel Botelho de Oliveira foi injustamente depreciado por um punhado de homens poderosos a capitanear uma crítica de ótica provinciana e orientada por critérios localistas, e que se recusavam a enxergar a produção de outros tempos em acordo com as preceptivas, formas e pressupostos das respectivas épocas em que os textos eram produzidos e onde circulavam. Ou seja, graças ao empenho de nossa crítica, o poeta tornou-se uma espécie de mito negativo de nossas práticas letradas: sorte de artefato cultural falso e remoto, a que se precisa chegar por meio de novos modos de aproximação, que levem em conta o ambiente de composição e a cultura oral de sua época.

Esses métodos seriam certamente muito diversos em relação àqueles propalados pelo poeta e historiador Gonçalves de Magalhães, que em 1836 afirmava que "a maioria dos autores coloniais ficaram alienados do éthos nacional no artificialismo da imitação de modelos metropolitanos" (HANSEN, 2002, p. 25). Antecedendo em noventa anos as palavras do brasileiro, em seu Verdadeiro método de estudar, publicado em Portugal clandestinamente no ano de 1746 , o português Luís 
António Verney (1713-1792) mostrava-se claramente contrário à poética seiscentista. $\mathrm{Na}$ "Carta Sétima", ele tripudia sobre as lições de Baltasar Gracián, como forma de estender suas censuras à produção de poesia durante o século XVII:

Li há anos um livrinho pequeno de um espanhol, que cuido era Gracián (...). Lembro-me que o autor, no prólogo, desejava ao livro a boa fortuna de cair em mãos de quem o entendessem. Polos meus pecados, eu fui um dos que não se cansaram em entendê-lo, porque logo entendi que o livro não merecia que se lesse (VERNEY, 1991, p. 137).

Avancemos. Na célebre Apresentação da poesia brasileira, reconhecida obra de fôlego publicada originalmente em 1946, Manuel Bandeira desfaz tanto a qualidade de Gregório de Matos e Guerra quanto a de Manuel Botelho de Oliveira, assumindo um tom de cunho sumário, e mesmo arrogante, que em muito relembra o sabor amargo dos críticos oitocentistas:

A importância de Gregório de Matos lhe advém da parte satírica de sua obra, a primeira que reflete em versos a sociedade da colônia, com o seu mestiçamento, o parasitismo português, os desmandos sexuais e outros males. Não foi um grande poeta, mas era uma personalidade forte, a primeira que assim se afirmava no Brasil, onde a sua posição corresponde proximamente à de Juan de Caviedes, no Peru. Ao lado dele mal se pode lembrar o nome de Manuel Botelho de Oliveira, autor de um medíocre poema descritivo intitulado A Ilha da Maré, cujo único mérito está em inaugurar o louvor do país em nossa poesia" (BANDEIRA, 2009, p. 14-15).

Mas vinte anos antes, Mário de Andrade - aquele que seria canonizado, ainda em vida, como nosso maior representante da estética modernista - repudiava o estilo na poesia de Luis de Góngora y Argote (1561-1627). ${ }^{170}$ Como se sabe, graves foram as consequências advindas da falta de uma avaliação menos preconceituosa e anacrônica por parte de uma crítica que desferiu violentos golpes contra o suposto artificialismo dos versos de Música do Parnaso. Um resquício disso pode ser visto nas palavras de Antonio Candido, apostas em um breve manual publicado no final da década de 1990:

\footnotetext{
170 "É a analogia, ou antes "o demonio da analogia" em que sossobrou Mallarmé. Mas a irmã bastarda da analogia a perífrase, parece-se muito com ela. A diferença está em que a analogia é subconsciente e a perífrase uma intelectualização exagerada, forçada, pretenciosa. É preciso não voltar a Rambouillet! É preciso não repetir Gongora É PRECISO EVITAR MALLARMÉ!" (ANDRADE, 1980, p. 240).
} 
A esse espírito entre devoto e cortesão se vincula um escritor de certo interesse, Manuel Botelho de Oliveira, exemplo típico do falseamento a que chegou o espírito barroco nos seus aspectos menores, quando a argúcia virou pedantismo ${ }^{171}$ e a sutileza um mero exibicionismo, dando a impressão de que a palavra rodava em falso, à procura de nada (CANDIDO, 1997, p. 24). ${ }^{172}$

De maneira geral, as apreciações a respeito do poeta são quase sempre pautadas pela brevidade dos exames e pela postura ora relativamente favorável, ora francamente negativa, em que são traçados perfis pejorativos do poeta e de sua produção de caráter supostamente artificial e pernóstico. Felizmente, outras vozes contrabalançaram a recepção ao legado de Manuel Botelho de Oliveira. Na História concisa da literatura brasileira, Alfredo Bosi revela-se como sendo um dos primeiros a reposiconar a visão mais condescendente a respeito da poesia de Manuel Botelho de Oliveira.

Dialogando com um ensaio publicado por Eugênio Gomes originalmente em $1958^{173}$ (que mais enaltecera o poema Ilha da Maré), Bosi afirmava estarmos "diante de um poeta-literato stricto sensu, capaz de escrever com igual perícia em quatro idiomas e nas várias formas fixas herdadas aos trovadores e aos renascentistas (...) [cujo] virtuosismo apela abertamente para os modelos da época" (BOSI, 2001, p. 41). Em 1977, José Guilherme Merquior enfatizaria a filiação de Música do Parnaso à tradição poética dos poetas espanhóis e italianos, sendo uma obra "Colocada sob o signo de Góngora e Marino (...) Lírica onde as convenções petrarquistas (...) e a excepcional acuidade das imagens visuais se articulam em engenhosos parelelismos sintáticos, estofados de expressões de significação ora convergente, ora divergente e antitética" (MERQUIOR, 1996, p. 32).

Tendendo para lados opostos, o fato é que a polarização de uns e outros não auxiliou em nada no resgate do autor e da adequada avaliação de seus versos. Além de

\footnotetext{
171 “(..) era pouco nítida a fronteira entre 'sábio' e 'pedante', pois o mesmo pedantismo alegado pejorativamente para constituir a inferioridade de muitos era efetivamente incentivado na formação de todos os letrados. Desde o colégio até à Universidade, os estudos feitos segundo os preceitos do Ratio studiorum da Companhia de Jesus previam justamente a memorização e a repetição de saberes tradicionais como fórmulas ético-políticas exemplares em todas as circunstâncias da vida de relação" (HANSEN, 2002, p. 41). Para Ivan Teixeira, ainda sobrevive a "convicção de que a poesia contribui para o mau gosto do leitor e seu afastamento da realidade imediata dos fenômenos dignos de imitação artística, que, basicamente, seriam a emoção pessoal, os embates da vida em sociedade e a relação do indivíduo com os valores responsáveis pela formação da nacionalidade" (TEIXEIRA, 2005, p. 36-47).

172 Essa passagem também chamou a atenção de Ivan Teixeira (2005), que, em seu estudo sobre a obra de Manuel Botelho de Oliveira, apresentou importantes ressalvas a consideração de Antonio Candido.

${ }^{173}$ Refiro-me a "A infanta e o javali", incluído por Eugênio Gomes em seu Visões e Revisões. Rio de Janeiro: MEC; INL, 1958.
} 
contribuir para a cristalização de uma injusta e depreciativa imagem do poeta e, por extensão, de outros escritores de seu tempo (basicamente, todos aqueles do século XVII) o fato é que o livro capital de Manuel Botelho de Oliveira só seria reeditado em raras ocasiões, no Brasil: todas elas no século XX. A primeira delas só se concretizou de modo parcial, chancelada pela Academia Brasileira de Letras, em uma breve antologia contendo apenas as rimas portuguesas - organizada por Afrânio Peixoto (1929).

A segunda edição transcorreu sob a responsabilidade de Antenor Nascentes, que escreveu brevíssimo estudo relativamente favorável na edição do INL (1953, sucedida por uma reedição, publicada pela Ediouro em 1967). Deve-se mencionar a cuidadosa preparação conduzida por Adma Fadul Muhana, editada pela Martins Fontes em 2005 mesmo ano em que foi lançada a versão fac-similar do livro, anotada por Ivan Prado Teixeira e publicada pela Ateliê Editorial. A ocasião foi propícia, aliás, para se comemorar o tricentenário da primeira edição da Música do Parnaso em Portugal.

Caberia lembrar que no início do século XVIII, publicar uma obra não era tarefa de somenos importância. Ela implicava o envio dos originais para a oficina tipográfica, antecedida pela concessão de licença do Santo Ofício, complementada pela autorização de sua publicação por pessoas autorizadas diretamente pelo Rei. Obedecendo aos trâmites de seu tempo e o entrelugar da capitania da Bahia no universo luso-brasileiro, Música do parnaso levou quase dois anos para ser publicado, tendo sido remetido por Manuel Botelho de Oliveira a Portugal em 1703.

\section{Textos Preambulares}

Dando sequência procedimental, e até certo ponto protocolar, à generosa e majestática dedicatória que escreve para Dom Nuno Álvares Pereira de Melo - seção em que Manuel Botelho de Oliveira enfatiza as adversidades representadas pelos "bárbaros índios" e do continente americano, "inculta habitação" (OLIVEIRA, 1953, p. 3) -, o poeta compõe um Prólogo mais enxuto, devidamente enquadrado pelo subtítulo "Ao leitor", que traz o discurso, antes sublime, de volta ao plano da medíocre da terra. A alternância entre os estilos elevado e mediano entre as seções pode ser considerada como uma deferência da parte de Manuel Botelho de Oliveira aos preceitos de Horácio (65 - 8 a.C.) 
e Longino (213?-273). De acordo com o que dizia o primeiro: "é de justiça, em determinadas matérias, consentir com o mediano e o tolerável" (HORÁCIO, 2010, p. 66).

Conforme o segundo: "Nos discursos, pois, o patético e o sublime, mais aproximados de nossa alma, graças a uma afinidade natural e ao brilho, sempre se mostram antes das figuras, obumbrando e mantendo encoberto o artifício destas" (LONGINO, 2010, p. 91). Substancialmente, os paratextos ("Dedicatória" e "Prólogo") que antecedem o coro de rimas atendem a uma demanda não só estética, mas também política, vigente entre os séculos XVII e XVIII: a de produzir textos com características que o aproximassem do encômio. Ou seja, quando compõe sua Música do Parnaso, publicada originalmente em 1705, Manuel Botelho de Oliveira aplica ao texto uma antiga lição da retórica.

A "Dedicatória" também pode ser compreendida como uma variante do gênero epidítico, uma vez que cumpre a dupla função de elogiar o destinatário do livro, elevando-o para a posição mais alta e poderosa no Império português, além de captar a autorização e patrocínio para a publicação de seus versos. Outro fator muito importante o corrobora: a "Dedicatória" ganha maior pujança e força quando comparada ao texto preambular seguinte, reservado ao leitor. Ou seja, o poeta concilia matérias, gêneros e estilos diferentes para cada texto que antecede os poemas. Note-se que a "Dedicatória" tem por sujeito o Primeiro Duque de Cadaval, matéria evidentemente nobre e que, portanto, comporta e justifica o emprego do gênero elevado (adequação entre matéria e gênero) e o estilo humilde, afetado pelo versejador, pois se coloca em posição inferior ao homenageado. Conforme assinalou Ivan Teixeira:

(...) a retórica tradicional entende a dedicatória como manifestação do gênero exortativo de discurso, tomado como sinônimo de deliberativo ou epidítico, por meio do qual o orador louva ou censura a matéria de sua invenção. Assim, pelos preceitos retóricos do tempo, a dedicatória de um livro deveria exaltar aquele que, com a autoridade de sua posição na hierarquia do Estado, protegesse a obra contra a malícia dos maus leitores (TEIXEIRA, 2005, p. 15)

Em severo contraste com a primeira seção do livro, o "Prólogo" revela outra face de Manuel Botelho de Oliveira, em que ele abandona o elogio à autoridade política e passa à explicação prévia do que se vai ler. Aqui ele está a falar para pessoas de condição igual ou inferior. Isso também explicaria o fato de ele ter sido escrito de modo mais 
objetivo, ou seja, estilisticamente casado ao caráter da persona autoral, beirando o didático: "ofereço neste lugar, para que se entenda que pode uma só Musa cantar com diversas vozes". Repare-se que o poeta afeta conduzir o leitor, antecipando-lhe as divisões dos versos e sua expressão de outrora: "No princípio celebra-se uma dama com o nome de Anarda, estilo antigo de alguns poetas". Ora, como salientava Ivan Teixeira, a poesia é um "evento cultural, que partilha de discursos sociais específicos, com normas próprias de invenção, de escritura e de circulação". Assim, é preciso "recompor, ainda que parcialmente, o sistema de referências segundo o qual o artista escrevia, sem o que se torna difícil sustentar uma visão histórica do fenômeno poético" (TEIXEIRA, 2005, p. 12)

No que diz respeito ao que afirma o poeta em seu "Prólogo", talvez o mais importante seja dito nas linhas em que parecem ressoar as palavras de Baltasar Gracián, "la variedad, gran madre de la belleza" (GRACIÁN, 2010, p. 136). Eis como Manuel Botelho de Oliveira aborda o mesmo assunto: "assim como a natureza se preza da variedade $^{174}$ para a fermosura das cousas criadas, assim também o entendimento a deseja, para tirar o tédio da lição dos livros" (OLIVEIRA, 1953, p. 9). Tanto as coisas naturais (lira $=$ emoção $=$ espontaneidade) como aquelas que se prendem ao artifício (entendimento $=$ razão $=$ cálculo) entram em poderosas analogias, o que sugere o diálogo dos pressupostos aplicados pelo poeta com os preceitos constantes dos manuais de seu tempo - em particular o Tratado de agudeza e engenho, publicado por Baltasar Gracián em 1642, para quem “La Semejança es origen de una inmensidad conceptuosa” (GRACIÁN, 2010, p. 180).

Vale lembrar que a palavra entendimento comparece muitas vezes ao manual do padre espanhol. Em seu tratado ela está relacionada a outra analogia fundamental segundo a ótica do conceptismo, uma vez que o conceito é recurso quem mais agrada o entendimento: “Entendimiento sin Conceptos es Sol sin rayos" (GRACIÁN, 2010, p. 137). Podemos supor ainda que, tanto nos paratextos ("Dedicatória" e "Prólogo") quanto nos poemas de Música do Parnaso, Manuel Botelho de Oliveira pretendesse estabelecer

\footnotetext{
174 "Como se sabe, a noção de variedade pressupõe a ideia de padrão. Básico na poética cultural dos Seiscentos, tal preceito se encontra sintetizado na Arte Poética de Horácio. Aí, a doutrina recomenda que, em lugar de inventar novos caracteres, o poeta deve limitar-se aos consagrados pelo costume" (TEIXEIRA, 2005, p. 59-60).
} 
uma forte ligação histórica e cultural com os temas e preceitos de tempos muito anteriores ao seu.

Isso nos levaria a considerar que Música do Parnaso permite o diálogo com as Poéticas de Aristóteles (escrita quatro século antes de Cristo), Horácio (um século antes de Cristo) e Longino (século III), além da alusão a determinados temas e gêneros poéticos cultivados pelos poetas portugueses da Idade Média, mas também por Petrarca (século XIV) e, especialmente, os versos legados por Luís Vaz de Camões, no final do século XVI. A consciência entre matéria, expressão e a forma é pressuposto assinalado pelo próprio poeta, que define seu ofício desta forma: "Poesia não é mais que um canto poético, ligando-se as vozes com certas medidas para consonância do metro" (OLIVEIRA, 1953, p. 9). Eis aí a confirmação de que, em seu caso, as vozes que entoam sua lírica ${ }^{175}$ sejam a contraparte do artifício, da técnica de composição em verso.

\section{Rimas da Agudeza}

Elemento relacionado à sonoridade, a consonância a que o poeta se referira no "Prólogo" ganha nova amplitude nos versos, mesmo porque ela se espraia infalivelmente nos vinte sonetos que dedica a Anarda - sorte de musa inspiradora, ainda que em carne e osso: uma figura de "candores" e "impia" que "pode dar" ao "rude discurso [do poeta] cultas flores" (Anarda Invocada, p. 12). O cruzamento semântico de palavras localizadas em versos alternados é uma das tônicas dos sonetos. O que se entenderia, hoje, por "rude discurso"? Discurso simplório, feito pelo homem bruto? 0 que de depreende de "cultas flores"? Flores que foram tratadas com cuidado pela beleza da "ímpia" e amada Anarda?

De fato, Anarda é pintada em condição superior e distante do eu-lírico. Não por acaso, o segundo soneto traz o título "Persuade a Anarda que ame", o que volta a sugerir o dado artificial que envolve o discurso lírico. Em Manuel Botelho de Oliveira, os afetos casam-se à razão que preside a fala. O que poderia redundar em poesia piegas, com vistas a melhor representar o eventual desvario do poeta, não ultrapassa os contornos

\footnotetext{
175 "a lírica se destina (...) a cantar seja a beleza, o bem amoroso, a amada, seja os homens virtuosos cujos feitos são dignos de se guardar na memória" (MUHANA, 2005, p. XXXVIII).
} 
da forma (rimas, métricas e ritmo) e do gênero (soneto). A matéria (amor, saudade, distância) está acomodada, portanto, à forma e ao gênero. Ao adequar matéria, estilo e gênero, o poeta revela a cuidadosa aplicação dos preceitos poéticos não exclusivos de seu tempo, o que não impede reconhecer a qualidade estética de seus versos.

Assim como Camões sugeria "transforma[r]-se o amador na cousa amada" (CAMÕES, 1963, p. 107), a persona poética de Botelho incita a Anarda para que sinta e sofra em seu lugar: "Avivas em teu peito o meu tormento,/Derramas por teus olhos o meu pranto" (Ponderação das lágrimas de Anarda, p. 13). Os sonetos não apenas evocam o nome da mulher, sugerida como mulher amada. O gênero em si favorece uma composição estruturada em comparações, quase sempre reservadas aos quartetos. 0 poeta parece seguir a lição de Baltasar Gracián de que "Alcança el nombre su conveniencia con la cosa denominada, no menos que las causas y efectos della" (GRACIÁN, 2010, p. 266)

Ao justapor Anarda ao sol, mas também ao céu e às flores, cumpre ao poeta cioso de imitar os arroubos de um eu apaixonado -, sugerir que "fermosura" da mulher que retrata seja equivalente ou mesmo superior aos encantos da natureza: "Pinta maios o sol, Anarda maios" (Sol e Anarda, p. 14). Consideremos o poema seguinte:

\section{Mostra-se que a fermosura esquiva não pode ser amada}

A pedra ímã, que em qualidade oculta

Naturalmente atrai o ferro impuro, Se não vê do diamante o lustre puro, Prende do ferro a simpatia inculta.

Porém logo a virtude dificulta, Quando se ajunta c'o diamante duro: Que um ódio até nas pedras é seguro, Que até nas pedras uma inveja avulta.

Prendendo pois com atração formosa A formosura, qual Ímã se aviva, É diamante a dureza rigorosa;

Aquela junta com a dureza esquiva, Não logra a simpatia de amorosa, Perde a virtude logo de atrativa (OLIVEIRA, 1953, p. 14). 
Isso permite dizer que algo de diferente acontece nesses versos, comparando-se àqueles em que se nota a costumeira presença de Anarda. No soneto, coisa rara, o poeta não menciona o nome da amada, embora possamos supor que dele também se trate, sob a forma da metáfora. Eis uma composição que toma "A pedra ímã" como sujeito que atrai o "ferro impuro" por obra da natureza, do qual "prende a simpatia" não cultivada, não polida (como seria a beleza do diamante). Na segunda estrofe, a virtude de atrair a "simpatia" não mantém a mesma integridade, o mesmo vigor quando a "pedra ímã" "se ajunta com o diamente duro", já que - apesar de simpáticas, as pedras são capazes de sentir "inveja" e "ódio". Enquanto a "pedra ímã" atrai por obra da simpatia, o "diamente duro" é belo, mas esquivo. Portanto, a formosura "Perde a virtude longo de atrativa" se for dura como o diamante e não atraente como a "pedra ímã”.

O sexto soneto traz uma engenhosa combinação entre o sentido da visão e a fala, ora contagiadas (o eu-lírico se diz "compelido") ora perturbadas (pelo "esquivo luzimento" e pelas "rosas" que "espinham") em acordo com os efeitos ora sugeridos, ora sofridos, pelo "cego deus" Cupido. Vejamos:

\section{Iras de Anarda Castigadas}

Do cedo deus, Anarda, compelido Vejo teu rosto, e digo meu tormento; Digo para favor do sentimento, Vejo para recreio do sentido;

As rosas de teu rosto desabrido, De teus olhos o esquivo luzimento: Este fulmina logo o raio isento Estas espinham logo ao deus Cupido.

Porém para experiências amorosas, Quando de amor as ânsias atropelas, As perfeições se mudam deslutrosas;

Porque tomando amor vingança delas, Nos rigores te afeia as lindas rosas, Nas iras te escurece as luzes belas (OLIVEIRA, 1953, p. 15). 
Redobremos nossa atenção ao título. Quem sofre as duras consequências por sentir "Iras" em relação a Anarda é o próprio eu-lírico, que está a enfrentar os castigos descritos nas estrofes. Cupido faz com que a visão da amada faça-o expressar seu "tormento". Se a fala contribuiu com a maior intensidade do que ele já padece, a visão colabora com a motivação do que ele de melhor sente. Observe-se que Anarda é retratada de modo a superar até mesmo as forças do deus do amor. Ela detém o brilho esquivo do olhar e profere palavras duras a partir de seus lábios. Duas imagens invertidas se justapõem: a delicadeza da rosa não impede que as palavras firam como espinhos. A firmeza do olhar não impede que ele seja esquivo.

Desse modo, ao desviar-se daquele que a ama, é "o olhar esquivo" que "fulmina o raio isento", inocente, sincero e puro de Cupido. Já as palavras "espinham", ou seja, maltratam, barram, anulam a chegada do melífluo discurso amoroso. Essa ambivalência é uma constante na poética de Botelho de Oliveira: "o poeta intensifica a adoção equívoca dos vocábulos, seja por meio do trocadilho, seja por meio da calculada polissemia da frase, seja por meio da exploração de efeitos da luz e das cores sobre os afetos" (TEIXEIRA, 2005, p. 24).

A explicação para o emprego equivocado dos termos se encontra ainda uma vez na Arte de ingenio, Tratado de la Agudeza: "La Primorosa equivocación es como una palabra de dos cortes, y un exprimir a dos luces. Consiste su artifício em encerrar debaxo de una misma dicción dos significaciones" (GRACIÁN, 2010, p. 277). Em meio à tempestade (outro sentido para o "tormento" reclamado pelo eu-lírico), resta ao poeta recorrer ao passado, às lições que pode tirar das "experiências amorosas". Afinal, quando os anseios, as expectativas são atingidos violentamente ("atropelados") pelo amor do presente, as cláusulas da fórmula podem se inverter, enfeiando até as palavras e tornando mesmo opaco o olhar da amada (futuro).

\section{Monte Parnaso}

Nos sonetos de Manuel Botelho de Oliveira, a confluência temporal, a que nos referimos, não parece gratuita. Ela se soma ao acúmulo de imagens que se cruzam ou se sobrepõem nos sonetos. Também a sonoridade é fator dos mais relevantes, tendo em vista o sugestivo título da obra: Música ("entoada" por um cantador) a partir do 
Parnaso, morada das musas e do Deus Apolo. Deve-se recordar que Apolo também foi um dos temas recorrentes no Canzoniere de Franscesco Pretrarca, em que o poeta dedicou centenas de sonetos a Laura ("Laure", em italiano) - nome poético tirado de Laureta de Novaes, que de fato existiu e com quem ele conviveu.

Repare-se, ainda uma vez, que a temática do amor fugidio, associada ao tom angustiado assumido pelo eu-lírico, parece ter sido retomada (melhor dizendo, introjetada) pela persona poética criada por Manuel Botelho de Oliveira, reconhecido petrarquista e camoniano:

\author{
Sí travïato è 'I folle mi'desio \\ a seguitar costei che 'n fuga è volta, \\ e de' lacci d'Amor leggiera e sciolta \\ vola dinanzi al lento correr mio \\ (PETRARCA, 2014, Soneto VI, p. 42)
}

Seria improvável, senão impossível, negar os ecos da dicção de Petrarca em Música do Parnaso. De maneira absolutamente próxima ao poeta italiano, Manuel Botelho de Oliveira elege um nome para o qual dedicar várias formas poéticas, dentre as quais ressalta o soneto (gênero que praticamente domina o Cancioneiro petrarquista). A tópica do amor esquivo gira em torno de Anarda, musa de feições terrenas que em muito lembra Laura, figurada por Francesco Petrarca, com mais de dois séculos de precedência. A fidelidade aos modelos poéticos anteriores evidencia o fato de que a leitura dos versos do poeta baiano ganhariam em muito se se considerasse o critério da auctoritas, relacionada às "práticas antigas do discurso, como modelos anônimos mediatizados por categorias da Retórica" (HANSEN, 1992, p. 15).

\title{
Som como Imagem
}

Para além da obediência à tradição, outro aspecto a se considerado diz respeito à musicalidade sugerida pela poesia de Botelho de Oliveira. A leitura, não exclusiva, dos sonetos do primeiro coro de rimas mostra que, ao compor os seus versos, o poeta alterna vogais e consoantes, como se estivesse a reproduzir em termos eufônicos a ambivalência dos sentidos emprestados às palavras, simultaneamente à oscilação do 
que sente e pensa, diante de Anarda, aquela que equivale a "dois maios", "dois sóis", de olhos "luzentes", mas "esquivos". Esse jogo sonoro, favorecido pela alternância dos sons, cunhados sob mesma métrica e ritmo, comparece tanto nos sonetos de Petrarca (em que o nome de Laura participa da composição estrutural dos sonetos), quanto na lírica camoniana, como revelam os versos seguintes:

Os dias, na esperança de um só dia, Passava, contentando-se com vê-la; Porém o pai, usando de cautela, Em lugar de Raquel Ihe dava Lia

[ou]

Um encolhido ousar; uma brandura; Um medo sem ter culpa; um ar sereno; Um longo e obediente sofrimento:

Esta foi a celeste formosura Da minha Circe, e o mágico veneno-amor Que pôde transformar meu pensamento (CAMÕES, 1963, pp. 106 e 107)

Na mesma chave, quando o poema de Manuel Botelho de Oliveira trata de coisas ligadas à candura - invariavelmente sob a ótica da desrazão e a premissa dos afetos -, com frequência enfileiram-se palavras de sonoridade adequada ao efeito pretendido, como se vê nas vogais nasais a traduzir mansidão:

Considera no sol, que luminoso

Ama o jardim de flores guarnecido (Soneto II)

Enfim dando ao jardim e ao céu demaios, $O$ céu ostenta um sol, dous sóis Anarda, Um maio o jardim logra; ela dous maios (Soneto $\mathrm{X}$ )

Esse vínculo, Anarda, luminoso, Do mínimo jasmim prisão dourada (Soneto XIV) 
Outras vezes, o efeito buscado é um tanto diverso. Neles, Botelho visa a traduzir a alternância de estados da persona poética entre a angústia, a dureza, a condição agreste de seu espírito e a esperança de conquistar o amor que o "eu" deseja:

\author{
Se és dura rocha no rigor impio, \\ Se és brilhadora luz na fronte amen; \\ A triste chuva de cristais serena, \\ Da sucessiva prata embarga o rio (Soneto III) \\ Porém para favor dos meus sentidos \\ Essas folhas castiguem rigorosas, \\ Os teus olhos, Anarda, os meus gemidos (Soneto XI)
}

Atente-se, também, para o papel assumido pelos sons vocálicos. Ao alternar as vogais abertas com as médias ou fechadas, muitos versos parecem reproduzir, na sonoridade, o movimento constante entre a alegria e a tristeza; entre a expectativa e a frustração; entre o peito aberto e os olhos cerrados. Eis uma das imagens mais frequentes nos sonetos de Manuel Botelho de Oliveira:

\footnotetext{
Quando em mágoas me vejo atribulado, Vem sono, a meu desvelo padecido, Refrigera os incêndios do sentido, Os rigores suspende do cuidado (Soneto XIII)

Se te aprisiona seu favor lustroso, Te retrata os efeitos de adorada; Porque quando te adorna a luz amada, Me aprisionas o peito venturoso (Soneto XIV)
}

Sem perder de vista essas breves sugestões de cunho estético, note-se que elas se somam à temática anunciada pelo título do livro. Especialmente por isso, não se pode desprezar a referência à morada dos deuses - evidenciada pelo próprio Botelho de Oliveira, logo nos primeiros parágrafos de sua "Dedicatória". Também nesse sentido, e em orientação oposta ao que sugere uma parte de nossa crítica mais tradicional, vale lembrar que Manuel Botelho de Oliveira era um fidalgo, tendo se bacharelado em Direito na Universidade de Coimbra, onde foi colega de Gregório de Matos e Guerra. 
Homem poderoso, diretamente ligado à administração portuguesa, foi um Capitão-Mor de mentalidade lusitana, senhoril e católica, com boas relações na corte portuguesa, o que provavelmente favoreceu que obtivesse a licença de evocar figuras da antiga mitologia latina, ao compor as rimas de Música do Parnaso, a evocar o tempo, o lugar e a postura de Apolo. ${ }^{176}$ Esse dado parece ser muito relevante e produtivo, uma vez que a persona poética fala do alto, vinculando o estilo do que escreve ao lugar elevado (monte Parnaso) e ao tema sublime (a natureza, o amor, a beleza extrema). Isso não quer dizer que houvesse arrogância ou altivez da parte da persona lírica inventada, ou, o que seria pior ainda, não nos permite julgar os versos pressupondo fatuidade e preciosismo do próprio Manuel Botelho de Oliveira. Pelo contrário, ao referir-se ao Parnaso, morada dos deuses, reforça o entrelugar da persona poética, cujas esperanças e lamentos sugerem o seu posicionamento como um ser radicalmente dividido entre a retidão apolínea e a sinuosidade do sentimento amoroso.

É o que se verifica em diversos momentos. A lágrima do homem e o veneno da serpente guardam em comum a característica de serem líquidas (“licores”), um vital, outro peçonha. Percorrendo os caminhos como se não tivesse rumo, o "coração queixoso" se move feito a "Serpe", "com passos mais oblíquos, que serenos" (Vendo a Anarda depõe o sentimento, p. 16). Claro esteja que "depor o sentimento" se traduz tanto pelo choro-sofrimento quanto pela inoculação do veneno-amor. Transparência e opacidade. Para ressaltar os gritantes contrastes entre o que se sente e o que se repele, em Cega duas vezes, vendo a Anarda o eu-lírico contrapõe os "sóis abrasadores" de Anarda aos olhos sofredores "de águas sucessivas", dicotomia anunciada na estrofe seguinte, em que "resplandores" rima com "desfavores". (p. 17)

Costumeiramente, Anarda guarda equiparações com elementos ou fenômenos da natureza. O nono soneto (Rigores de Anarda na ocasião de um temporal), desenhase de modo terrível, com direito a "ventos duplicados" e relâmpagos ("setas de prata despedidas"), devido à fúria do céu. A seu turno, Anarda despreza os tormentos alheios, lançando "Os raios dos rigores contra as vidas" e "As nuvens dos desdéns contra os

\footnotetext{
${ }^{176} \mathrm{~A}$ julgar pela desfaçatez e o modo perfeitamente à vontade com que Luís António Verney se referia à poesia "barroca", talvez suas palavras representassem boa parte da concepção de "literatura", segundo a crítica luso-brasileira, no século XVIII: "Nunca pude sofrer um poeta, no princípio de um poema moderno, invocar as Musas e Apolo para Ihe inspirarem os pensamentos (...) Nós temos na nossa religião coisas que podem suprir a todas as ideias dos antigos" (VERNEY, 1991, p. 140).
} 
cuidados" (p. 17). Eis-nos trazidos novamente em presença da figura de olhar esquivo, a sintetizar as muitas formas com que a amada recusa ou se desvia frente aos sentimentos, preocupações e palavras doces do eu-lírico: “Em ti já vejo a Anarda, ó Tejo esquivo" (Ponderação do Tejo com Anarda, p. 20); "teus desdéns esquivos" (Anel de Anarda ponderado, p. 21).

No entanto, a breve ira vem a ser constantemente contrabalançada pela constância e a intensidade do que ele sente, o que o leva a sugerir que "O céu ostenta um sol, dous sóis Anarda" (Ponderação do rosto e olhos de Anarda, p. 18); "Que a rosa deve ao sol seu luzimento,/O sol seu luzimento a Anarda deve" (Rosa, e Anarda, p. 26). Mas o amor não se limita a sobrevalorizar a imagem da figura feminina. Repitamos: ao compor seus versos, Manuel Botelho de Oliveira aplica as lições constantes de diversos manuais que circulavam em seu tempo, como aquele de Manuel Pires de Almeida (15971655) que, colado a Horácio, afirmava que "as mesmas regras e os mesmos preceitos têm a pintura que a poesia (...), mas sem dúvida é indústria e natureza, arte e engenho o que os inclina a estas duas faculdades nascidas de um mesmo ventre e de um mesmo parto" (ALMEIDA, 2002, p. 75).

Ainda que determinadas escolhas representem a eternalização de seu martírio, o eu-lírico deseja representar sua amada em pedra, como se a equiparar a extensão do que sente com a memória imortal de Anarda: "Para esculpir a estátua imaginada,/Logo derrete o bronze lagrimoso" (Anarda esculpida no coração lagrimoso, p. 22). Ora, amar também significa sentir-se morto em vida, o que aproxima Manuel Botelho de Oliveira da melhor tradição da poesia lírica: “Anarda própria me deseja a morte,/Anarda própria me defende a vida" (Efeitos contrários do rigor de Anarda, p. 24).

Na sua poesia, o amor e a morte estão em conflito constante, o que tanto permite posicioná-lo como legítimo herdeiro da estética greco-latina, quanto aproximálo da lírica trovadoresca franco-portuguesa, quanto da poesia de inspiração neoplatônica de Petrarca e Camões, sem esquecer os sonetos de Shakespeare e o estilo de Gôngora. Esse panteão de filósofos e versejadores que o antecederam, ao longo dos séculos, por si só assegura a intenção de emular a poesia dos melhores. Além disso, o fato de seguir e respeitar a tradição, em acordo com os preceitos e concepções em sua época revela o fato de sua obra ser firmemente orientada por modelos poéticos de 
outros tempos e lugares, que não o nosso, pretensamente original e alocado em vários lugares ao mesmo tempo.

Reconhecer a filiação de Manuel Botelho de Oliveira à melhor tradição do gênero lírico para além do universo ibérico, inclusive, constitui uma atitude sábia. Esse passo (essencial) deve ser o primeiro para que se proceda a uma efetiva reavaliação certamente positiva de sua obra - e, consequentemente, para a (re)validação de outros poetas do mesmo período em que ele viveu. Vamos a eles. 


\section{Referências}

ALMEIDA, Manuel Pires de. Poesia e Pintura ou Pintura e Poesia. Tradução: João Ângelo Oliva Neto. São Paulo: Edusp; Fapesp, 2002 [Edição de Adma Fadul Muhana].

ANDRADE, Mário de. Obra imatura (Há uma gota de sangue em cada poema/Primeiro andar/A escrava que não era Isaura). 3a ed. Belo Horizonte: Itatiaia, 1980.

ARISTÓTELES; HORÁCIO; LONGINO. A poética clássica. 15a ed. Tradução: Jaime Bruna. São Paulo: Cultrix, 2010.

BOSI, Alfredo. Botelho de Oliveira. In: História concisa da literatura brasileira. 39a ed. São Paulo: Cultrix, 2001.

CAMÕES, Luís Vaz de. Lírica. São Paulo: Cultrix, 1963.

CANDIDO, Antonio. Iniciação à literatura brasileira (resumo para principiantes). São Paulo: FFLCH: Humanitas, 1997.

GOMES, Eugênio. A infanta e o javali. In: . Visão e Revisão. Rio de Janeiro: INL; MEC, 1958.

GRACIÁN, Baltasar. Arte de ingenio, Tratado de la Agudeza. 2a Ed. Madrid: Ediciones Cátedra, 2010.

HANSEN, João Adolfo. Autor. In: JOBIM, José Luis. Palavras da crítica. Rio de Janeiro: Imago, 1992.

. Fênix renascida \& Postilhão de Apolo: uma introdução. In: PÉCORA, Alcir (Org). Poesia seiscentista. São Paulo: Hedra, 2002.

MERQUIOR, José Guilherme. De Anchieta a Euclides: breve história da literatura brasileira. 3a ed. Rio de Janeiro: Topbooks, 1996.

MUHANA, Adma. Introdução. In: Poesia completa: Música do Parnasso, Lira Sacra (Manuel Botelho de Oliveira). São Paulo: Martins Fontes, 2005.

NASCENTES, Antenor. Prefácio. In: OLIVEIRA, Manuel Botelho de. Música do Parnaso. Tomo I. Rio de Janeiro: Instituto Nacional do Livro, 1953.

PETRARCA, Francesco. Cancioneiro. Tradução: José Clemente Pozenato. Cotia (SP): Ateliê Editorial; Campinas (SP): Editora da Unicamp, 2014 [Versão bilíngue].

PONTE, Pero da. Se eu pudesse desamar In: MONGELLI, Lênia Márcia. Fremosos cantares (antologia da lírica medieval galego-portuguesa). São Paulo: WMFMartins Fontes, 2009. 
TEIXEIRA, Ivan Prado. A poesia aguda do engenhoso fidalgo Manuel Botelho de Oliveira. In: OLIVEIRA, Manuel Botelho de. Música do parnaso. Cotia (SP): Ateliê Editorial, 2005.

VERNEY, Luís António. Verdadeiro método de estudar (cartas sobre retórica e poética). Portugal: Editorial Presença, 1991. 


\section{A Conquista de Goa, Exercício Poético}

Cette puissance est absolue et souveraine, car elle n'a outre condition que la loy du Dieu (Jean Bodin). ${ }^{177}$

[...] nasce da angústia a imaginação, do imaginar o discorrer, \& começa a polir-se o entendimento com os exercícios do cuidado (Frei Lucas de Santa Catarina). ${ }^{178}$

As regras são tantas e tão dificultosas, que são poucos os que se atrevam, e raríssimos os que não pequem contra algumas (Luís Antônio Verney). ${ }^{179}$

Resumo: No artigo, analisam-se episódios da epopeia A Conquista de Goa, publicada em 1759, por Francisco de Pina e de Melo, Fidalgo da Corte portuguesa. Na interpretação, levam-se em conta os textos preambulares que enformam o poema, as preceptivas a que o autor alude e os poetas da tradição greco-latina e da Era Moderna que ele emula.

Palavras-Chave: Literatura Portuguesa; Epopeia; Pina e Melo; A Conquista de Goa.

Abstract: In this article we intend to analyses some episodes from A Conquista de Goa, a Francisco de Pina e de Melo's epic poem that was edited in 1759 at Portuguese Court. In this interpretation we consider the poem preambular texts, preceptives alluded by the author and poets from Greco-Roman tradition and Modern Era.

Keywords: Portuguese Literature; Epic; Pina e Melo; A Conquista de Goa.

Pouco se sabe a respeito de Francisco de Pina e [de] Melo (1695-1773), filósofo e poeta português que integrou a Academia Real da História Portuguesa, inaugurada em 1720. No frontispício de sua epopeia A Conquista de Goa, publicada em 1759, consta que era "Moço Fidalgo da Casa Real". Figura que pouco circulara na Corte durante o reinado de Dom José I, as notícias mais consistentes a seu respeito constam de A Arcádia Lusitana (1899), de Teófilo Braga; Retórica e Teorização Literária em Portugal (1973), de Aníbal Pinto de Castro; e o segundo volume das Lições de Cultura e Literaturas Portuguesas, de Hernani Cidade (1975). Separados por quase um século, todos eles

\footnotetext{
177 Les Six Lois de La Republique, Livre Premier, Chapitre IX [“Esse poder é absoluto e soberano, pois só se condiciona à lei de Deus"]. (BODIN, 1576, p. 130). De acordo com Rafael Ruiz (2002, p. 63), "Para [Francisco] de Vitória, a potestade civil tem duas características: sua origem natural - e, portanto, divina enquanto criada por Deus - como causa eficiente; e sua origem humana, no que diz respeito à concretização do poder nos diferentes povos e tempos. Nesse sentido, a natureza do poder está por cima da própria vontade humana e, por isso, todos os reis, imperadores e príncipes dos povos são soberanos no mesmo grau de hierarquia e importância".

178 Serão Político, Abuso Emendado (TURACEM, 1704, p. 39).

${ }^{179}$ Verdadeiro Método de Estudar, Vol. 2 (VERNEY, 1950 [1746], p. 303).
} 
remetem à biografia de um homem letrado que frequentou círculos restritos e escreveu sobre retórica, poesia e religião. ${ }^{180}$

Em outros casos, as notícias a seu respeito - quando as há - são tanto ligeiras quanto imprecisas e servem mais a validar a concepção tradicional de literatura - que elegia poetas "originais" e "epígonos" -, herdada aos antologistas do século XIX. O paradigma desse impressionismo acrítico, referendado em uma cadeia de repetições, também orienta a conhecida História da Literatura Portuguesa, de Antônio José Saraiva e Óscar Lopes (1996, p. 602), onde afirmam que um dos "tópicos" da teorização árcade envolveria a:

Apologia do equilíbrio razoável, da seleção ponderada, o que implica a condenação, tanto do plebeísmo, como da sutileza conceitual do bucolismo seiscentista, particularmente em Rodrigues Lobo e D. Francisco Manuel (tópico especialmente versado em duas dissertações polêmicas de Cruz e Silva contra o poeta bucólico Pina e Melo, o "Corvo do Mondego", 1695-1765 [sic], que outros árcades ridicularizam também, e que todavia é na sua Arte Poética em verso, 1756 , um doutrinário do classicismo, embora a sua obra lírica ainda tenha traços barrocos, com um sensível gosto pelo tenebroso que se antecipa ao préromantismo).

Coalhada de anacronismos, decorrentes de uma concepção teleológica e evolucionista ("classicismo", "traços barrocos", "pré-romantismo"), os historiadores desqualificam o poeta e sua obra, combinando termos imprecisos que apontam para três "movimentos literários" situados em períodos históricos distintos e que, em rigor, não admitiam o sentido que Ihes foram atribuídos somente a partir do século XIX. Como observa João Adolfo Hansen (2008, p. 19):

Para ler a epopeia historicamente, deve saber que, até a segunda metade do século XVIII, os códigos da poesia foram retóricos, imitativos e prescritivos, diferentes dos critérios expressivos e descritivos da estética, da crítica e da história literária então inventadas pela revolução romântica que subjetivou todas as artes como expressão da consciência infeliz dividida e multiplicada pelo dinheiro.

\footnotetext{
180 "Pina e Melo nascera em 1695, e como sexagenário mal adoptaria as doutrinas dos jovens reformadores da literatura. Era um dos membros da Sociedade dos Ocultos em magníficas relações com os fidalgos a quem lisonjeava em pomposos Epitalâmicos, em Genetlíacos e Odes. Garção tratava-o pelo nome de Corvo do Mondego, Valadares e Sousa criticara asperamente seu poema A Conquista de Goa, e Dinis, em suas Conferências na Arcádia, discutiu largamente sobre a sua Bucólica" (BRAGA, 1984, pp. 134135). "Para Garção[,] devia a poesia ser de nobre simplicidade e pureza de frase. Não poupa o gongorismo, que em certos aspectos procura resistir, defendido por Francisco de Pina e de Melo, aquele a quem os árcades chamam o Corvo do Mondego" (CIDADE, 1975, p. 255).
} 
Seria de grande interesse saber o que o consulente do manual de Saraiva e Lopes deveria entender pela expressão "apologia do equilíbrio razoável"; como poderia interpretar a contraposição entre "plebeísmo" e "sutileza conceitual" na poesia do Setecentos; e, finalmente, como reagir diante da afirmação de que diversos contemporâneos de Pina e Melo o "ridicularizassem". A importância de certos manuais de historiografia literária precisa ser revista, especialmente quando colaboram para a redução do já estreito cânon literário, embora pretendam ser calçados pela história.

O fato é que, embora Francisco de Pina e Melo seja praticamente esquecido hoje, há grande interesse em ler $A$ Conquista de Goa, que apresenta uma versão alegórica e mitológica das batalhas travadas nas terras da Índia, em 1510, resultante da parceria de Afonso Albuquerque e Timoja ${ }^{181}$ - um indiano que, expulso de seu país, atuava como pirata - contra o domínio muçulmano naquele território. O poema, simetricamente distribuído em dez cantos, vem precedido de um pequeno tratado sobre a épica, composto pelo próprio poeta - que recorre a Aristóteles, Horácio ${ }^{182}$, Ignacio de Luzán, e especialmente ao Abade Le Batteux (vide o Cours de belles-lettres, publicado em 1765), para melhor discorrer sobre o gênero e justificar a sua obediência aos preceitos da $\operatorname{arte}^{183}$, entre greco-latinos da Antiguidade e seus contemporâneos do século XVIII.

Le Batteux, confrontando a História com a Epopeia, diz que aquela se destina à verdade, e esta ao fingimento: Quando a História tem dito sinceramente como foram os sucessos, tem cumprido com tudo o que dela se podia esperar; porém, que a Epopeia não se cinge a estes limites; porque deve encantar o Leitor com as suas ficções, excitar-lhe a sua admiração, ocupar-lhe ao mesmo tempo o seu discurso, a sua imaginação, o seu Espírito, penetrar-Ihe o Coração, arrebatar-Ihe os sentidos; e fazer com que ainda se ponha como em um êxtase deleitável, que se por algum instante se interromper, seja só para renovar este deleite com maior vivacidade (MELO, 1759, p. IX).

\footnotetext{
181 "De vinte e três navios se compunha/ A Esquadra Lusitana (...) seguindo a Capitana / Deram fundo em Onor, querendo Afonso / Consultar com Timoja o movimento / Que melhor estivesse ao nosso alento (MELO, 1759, pp. 230-231). O episódio remete à tradição. Tanto na Eneida, como em Os Lusíadas, os heróis estabelecem parcerias com outros povos.

182 "Menos radical do que Verney, Pina e Melo, apoiado em Aristóteles, aproximava-se mais da teoria quinhentista baseada em Horácio, sem, no entanto, citar a Epístola aos Pisões. Embora subscrevesse tudo quanto encontrara no Vedadeiro Método [de Verney] acerca das três espécies de estilo - sublime, medíocre e ínfimo - não concorda em que o sublime 'era só peculiar aos Poetas, e muito distante do que se prescreve a Oradores e Pregadores" (CASTRO, 2008, p. 500).

183 "Tudo isto, que pede Le Batteux na Epopeia, me parece que estará satisfeito na Conquista de Goa" (MELO, 1759, p. XV).
} 
A disposição da obra com quase quatrocentas páginas, entre paratextos e cantos, sugere que $A$ Conquista de Goa também deve ser considerada como exercício em que há aplicação eficaz de preceitos e regras, a respeitar elocução e estilo convenientes que especificavam e orientavam a feitura da epopeia ${ }^{184}$, centrada no herói:

As personagens, que entram a falar na Epopeia (a que chamamos Dramas) devem ser distinguidas pelos seus caracteres: Os seus costumes devem ser próprios, e sustidos sempre em todas as suas práticas, e pensamentos: E de tudo isto se deve fazer um todo, ordenado, e proporcionado perfeitamente com todas as suas partes" (MELO, 1759, p. IX).

Esses fatores reforçam a hipótese, corrente desde a década de 1980, de que os homens letrados do século XVIII estavam familiarizados com preceitos retórico-poéticos e, ao emularem poetas considerados modelares ${ }^{185}$, filiavam-se àquela tradição constituída por auctoritates ${ }^{186}$. Os efeitos pretendidos pelo poema apelavam para razão do leitor discreto - ou seja, capaz de discernir as técnicas empregadas -, visando ao seu deleite $^{187}$ (vide as descrições vívidas, metáforas agudas, estilo sublime ${ }^{188}$ etc.) e persuasão, mesmo porque Francisco de Pina e Melo argumentava em defesa do projeto expansionista português, iniciado no século XV: “A ação, não só deve ter grandeza, mas integridade ; pois nenhuma coisa pode ser perfeita, sem ela; e não há quem duvide que na Epopeia se deve procurar a maior perfeição; por ser o mais sublime esforço, que se pode esperar do engenho humano" (MELO, 1759, pp. XII-XIII). De uma perspectiva teológico-política, importa assinalar que o poeta se declara súdito fidelíssimo à Sua

\footnotetext{
${ }^{184}$ Lemos na Poética de Aristóteles: "[...] a epopeia acompanhou a tragédia somente na medida de ser, com metro e linguagem, mimesis de <ações> elevadas; mas, pelo fato de ter o metro único e de ser uma narração, desse modo diferem" (ARISTÓTELES, 2018, p. 45).

185 "[...] a Fábula deve ser Exemplar, e digna de ser imitada" (MELO, 1759, p. XIV).

186 “Em latim, desde o período itálico, a auctoritas - como /autoridade/ e /autoria/ - parece pertencer à língua religiosa e do direito. Émile Benveniste propõe que a auctoritas qualifica a ação própria de um deus; assim, toda palavra pronunciada com a auctoritas ritual determina uma mudança no mundo, concepção que encontra equivalência nas práticas rituais vedas ou gregas arcaicas, em que o discurso vale pelo que faz, ou pelo modo da sua enunciação" (HANSEN, 1992, p. 17).

187 "[A Epopeia] não deve ser grande, e inteira, mas útil, e que faça interessar nela os seus leitores: Há dois modos de interessar para a fazer gostosa, e amável: Um, que provém da mesma natureza da ação; outro dos nexos; ou obstáculos, que nela se propõem que desejamos ver vencidos, ou delatados. 0 primeiro modo comumente nos comove; o segundo excita a nossa curiosidade, e faz interessar todos os impulsos do nosso desejo" (MELO, 1759, p. XIII).

${ }^{188}$ Recomenda Longino, no Tratado do Sublime: "[...] um verdadeiro Orador não deve ter espírito humilde e desprezível; porque não é possível que aqueles que são acostumados a pensar baixa e servilmente e que nisto trabalham toda a sua vida, hajam de produzir coisa admirável e digna de toda a posteridade" (LONGINO Apud OLIVEIRA, 1984, p. 60).
} 
Majestade e à Igreja Católica, sujeito à onipotência papal, obediente ao pacto de sujeição ${ }^{189}$ e respeitador da rígida hierarquia reinol:

Além do interesse da Nação, há também o da Religião, e este interesse ainda é mais extenso: Qualquer, bom Católico se deve interessar no Poema do Tasso pois todos devem estimar o triunfo, que alcançou naquele tempo a Igreja com a restauração da santa Cidade. E por isto mesmo se havia de estimar o meu Triunfo da Religião: Porém se os Eclesiásticos o criticaram, que posso eu esperar dos Seculares? (MELO, 1759, p. XIII).

Francisco de Pina e Melo dedica o poema ao sobrinho de Dom João V, "Dom Pedro Henrique de Bragança Sousa Tavares Mascarenhas da Silva, primeiro Duque de Lafões" e declara, com ensaiada modéstia: "Menos as forças, que o atrevimento, me levaram a este grande arrojo com o meu Triunfo da Religião, que agora repito, sem me apartar da mesma temeridade com a Conquista de Goa" (MELO, 1759, p. VII). Atento aos parâmetros da épica tradicional, que recomenda adequar o assunto ao gênero e estilo e dos versos que compõe $\mathrm{e}^{190}$, Francisco de Pina e Melo explicita o argumento do poema, diferenciando Hábito, Ação e Paixão:

Eis aqui o que se chama ação: o hábito é o princípio remoto da ação; e a paixão[,] o próximo; e a mesma ação se executa com mais ou menos vivacidade, segundo o Ímpeto, ou a moderação, que recebe dos seus princípios. Este exemplo nos dá a conhecer a ação deste Poema. Era grande o amor, que tinha à glória da nação Afonso de Albuquerque: aqui temos o hábito ou o princípio remoto: Este amor o fez conceber a paixão de estabelecer o nosso Império na Ásia: aqui está o

\footnotetext{
189 “As teorias do contrato social vão desde os pactos entre soberanos e súditos (pactum subjectionis) ao pacto entre os habitantes (pactum societatis). A primeira versão é sustentada principalmente nos escritos políticos do século XVI, representando um esforço de prover fundamento ideológico à limitação dos poderes dos monarcas. A segunda versão é desenvolvida da ideia da soberania popular que acompanhou a ascensão da burguesia. Assim, no século XVII, os dois contratos apareciam nos escritos de Grotius, Puffendorf e Hobbes. Mais tarde pode-se ver como o pactum societatis torna-se o fundamental, em Hooker e Locke. Este contrato é o único, em Rousseau, que elimina o pactum subjectionis" (ISUANI, 1984, p. 36). Um dos primeiros tratados que versam sobre o pactum subjectionis é Les Six Livres de La Republique, de Jean Bodin, publicado em 1576. Depois dele, deve-se mencionar a Política, de Althusius, publicada em 1603. Conforme Wladimir Brito (2005, p. 275), “Cabe a Althusius, (...) na sua obra maior a Politica Methodice Digesta (vulgarmente conhecida por Política), publicada em 1603, onde nos propõe uma nova ideação desse corpus symbioticum, enquanto corpo organizado com personalidade própria e distinta da dos governantes, que - e aqui surge a primeira grande inovação althusiana - dispõe de potestas imperandi universalis (poder universal de governo) e que nasce de um pacto - pactum constitutionis entre várias categorias de corpus - as cidades e as províncias - que as unifica numa consociationi com um direito próprio, o ius symbioticum. Mas, a esse pacto acresce um outro que é o pactum subjectionis ou pactum submissionis, celebrado entre o povo e os seus representantes".

190 "[...] a Epopeia nos admira, a Tragédia nos entristece, a Comédia nos alegra, a Bucólica nos serena" (MELO, 1759, p. XV).
} 
princípio próximo: um e outro princípio, o fez executar a Conquista de Goa: Eis aqui a ação da minha Epopeia (MELO, 1759, p. X).

Após discorrer sobre o éthos do herói (Afonso de Albuquerque) ${ }^{191}$ e a qualidade de suas ações, Pina e Melo (1759, p. XI) subordina os episódios ao argumento principal, anunciado na Proposição:

Os Episódios são umas partes do Poema subordinados à ação principal, ou como dizem outros, uns modos da mesma ação com que ela se amplifica e se lhe dá a sua devida grandeza. A cólera de Aquiles na llíada, e o estabelecimento de Eneias na Itália, se não tiveram estas modificações, se poderia reduzir a menos de mil versos qualquer desses dois Poemas. Servem também os Episódios pela sua variedade, de fazerem deleitável a leitura da Epopeia.

Para o poeta, a disposição da epopeia deveria levar em conta a variedade de afetos despertados no leitor, como procedera Virgílio. Para provocar tais efeitos, recomendava que os episódios primassem pela alternância de paixões (MELO, 1759, p. XII):

Devem os Episódios ser também diferentes: Uns amorosos, outros patéticos, outros alegres, fúnebres, horrorosos etc. e, saindo-se de um Episódio v. g. fúnebre, não se lhe deve seguir um Episódio triste, não só atendendo à variedade, porém a levar o leitor comovido, com diferentes afetos.

Os preceitos e os artifícios empregados em A Conquista de Goa são explicitados pelo poeta, como se vê nesta caracterização do gênero épico e suas implicações: “[...] o fim principal das Epopeias é propormos ações sublimes, maravilhosas, e exemplares para delas fazermos uma boa imitação; e estas ações por si mesmas estão persuadindo que tem melhor desempenho nos impulsos heroicos, que nos apaixonados" (MELO, 1759, p. XIV). Em “Da Epopeia”, a ênfase recai no caráter do herói e nas ações que protagoniza ou de que participa. Esse entrelaçamento entre a personagem e os episódios é necessário, uma vez que:

Os obstáculos a que os Épicos chamam nexo, e as soluções, com que se desatam, vão notados neste Poema; e uma, e outra coisa é que leva suspenso o Leitor até o fim da Empresa: Para conseguir a admiração (diz o mesmo Le Batteux) e para arrebatar a alma, é preciso que os nexos, que se propuserem ao Herói, sejam de uma dificuldade extraordinária, e que pareça que necessitam de uma força

191 “[...] pede a boa razão que o Herói se proponha de sorte que o mesmo leitor tome interesse em todas as suas felicidades: Para isto é necessário fazê-lo amável pelas suas virtudes, e fazer com que a ação seja digna de que nela as exercite" (MELO, 1759, pp. XV-XVI). 
sobrenatural para os vencer, o que não obstante consegue o Herói o triunfo. E cuido que assim o temos praticado na Conquista de Goa (MELO, 1759, p. XVII).

Algo também deve ser dito sobre a usual confusão entre a voz do homem letrado (ou pessoa empírica) e a da persona poética ${ }^{192}$ : questão para que diversos estudiosos chamam atenção há décadas. Os mesmos críticos capazes de fixar datas e canonizar obras-marco; hábeis em dissecar ordens, regramentos, convenções, gêneros, métrica, rima e ritmo poéticos, costumam ser aqueles que desconsideram, ignoram ou desprezam os múltiplos artifícios sabidamente empregados em variados gêneros, especialmente entre os séculos XVI e XVIII ${ }^{193}$. Nesses casos, os anacronismos quase sempre se unem ao impressionismo ligeiro, que atribui sentimentos verdadeiros ao poeta (confundido com a voz que enuncia o poema), aventando hipóteses insustentáveis, por exemplo, de que uns e outros teriam ideias fixas - de Luís Vaz de Camões a Cruz e Souza, passando por Bento Teixeira, Manuel Botelho de Oliveira, Francisco de Pina e Melo, Cláudio Manuel da Costa, Tomás Antônio Gonzaga, Sapateiro Silva, Bocage, ou Marquesa de Alorna).

Ao conferir determinadas posturas aos poetas, com base na hiperinterpretação dos versos que se lhes atribuem, esses historiadores peneiram idiossincrasias, talvez para fins didáticos, dependuradas entre as supostas virtudes e vícios que imprimem aos poetas. Esse modelo crítico precisa ser revisto. Para isso, o investigador deve ler, efetiva e atentamente, os textos que pretende discutir. Além disso, terá que se recordar de que, na confecção dos versos interferem: a forma mentis vigente no tempo em que foram redigidos; os meios de produção e a expectativa de circulação dos textos em círculos restritos; o papel da religião e do Estado, no endereçamento do poema; o ordenamento social e jurídico das sociedades de Corte etc. Esses e outros fatores precisam ser considerados, em sua análise e interpretação.

\footnotetext{
192 Francisco Achcar (1994, p. 53) observava que “[...] não há motivo para supor que o uso sistemático de lugares-comuns implique necessariamente, "neutralidade" do eu-lírico e, pois, inautenticidade ou insinceridade".

193 Frei Lucas de Santa Catarina, na "segunda noite" do Serão Político, Abuso Emendado, questiona: "Pois Claudiano foi algum inocente? Virgílio algum mamote, \& Gôngora algum orate? Isso que repetes (tornou a Verdade) nenhum o escreveu para apoio da fábula, mas para gala da Poesia, arte tão naturalizada nos fingimentos, que chegou a dizer Aristóteles, que aquele era o mais verdadeiro Poeta, que fingia melhor" (CASTANHEIRA, 1704, p. 121).
} 
Bastaria lermos esta declaração de Pina e Melo, localizada no texto em que discorre sobre as regras do gênero épico, para confirmar que A Conquista de Goa resulta de um trabalho consciente, pautado pela emulação de Virgílio e aplicação das preceptivas recomendadas à narração de feitos sublimes, praticados pelo governador convertido em herói: “[...] quando a ficção é tão natural, que parece sucesso, se pode reputar com todas as qualidades que se procuram nestes fingimentos Poéticos" (MELO, 1759, p. 18). A epopeia de Pina e Melo divide-se nas partes que recomenda a tradição do gênero. A Proposição concentra-se na quadra ${ }^{194}$ inicial:

Canto o insigne valor de um braço forte, Que dominando o Abismo, o Fado, e a Morte, Com impávido esforço, e mais que humano. Fundou no Oriente o Império Lusitano (1759, p. 1).

A Invocação ocupa os versos seguintes. O enunciador invoca a "inteligência divina", de maneira que alcance:

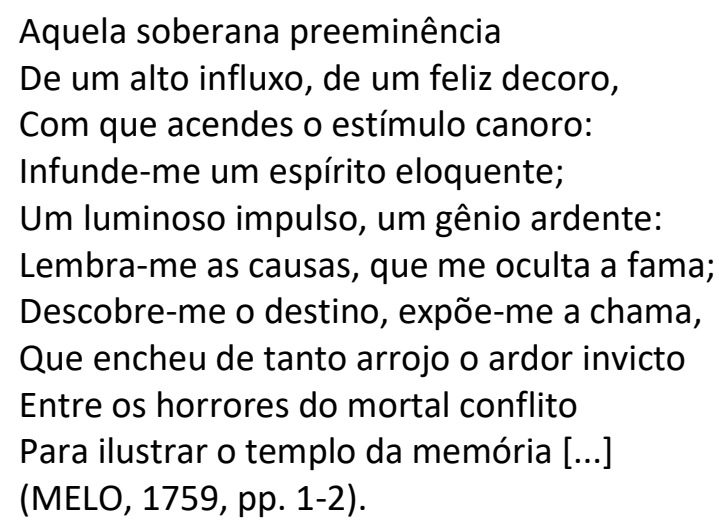

O segundo ente a ser invocado é o Dom José I, cuja benevolência, magnanimidade e virtude corrigirá as imperfeições do poema:

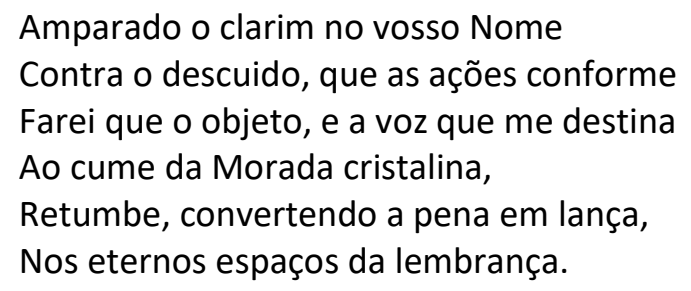

\footnotetext{
${ }^{194} \mathrm{Em}$ nota do próprio poeta ao Canto I, lê-se: "Estas são as regras comuns da Proposição: as especiais (diz Luzán na sua Poetic. lib. 4. cap. x.) se reduzem a que seja livre, e alheia de toda a pompa, e afetação. Le Batteux também quer que ela seja simples, clara, e sem presunção, nem ornato: este preceito é tirado da Arte poética de Horácio, quando condena ao poeta Cyclio pela inchação com que propôs o seu Poema" (MELO, 1759, p. 3).
} 
(MELO, 1759, p. 4).

Chama atenção que, tanto ao invocar Deus, quanto na súplica ao Rei, a persona poética enfatize o valor das matérias de que discorrerá, convertendo seu poema em uma peça encomiástica, expresso em linguagem tão elevada quanto o leitor a quem dedica os versos. Ivan Teixeira (1999, p. 70) mostrou que:

Em Portugal, o grande modelo desse tipo de composição são os Panegíricos, de João de Barros, cuja leitura ensina que o elogio aos nobres, longe do conceito atual de simples bajulação, tinha a função não só de glorificar o merecimento das ações do elogiado, mas também de instruir os de mais baixa condição pela força do exemplo.

Não é demasiado lembrar que a epopeia é o gênero mais adequado para representar narrativas de grandes feitos, por homens de fama imorredoura, situados no pretérito, o que explica o registro no "tempo da memória"195 e a localização nos "eternos espaços da lembrança". Na síntese de Hansen (2008, p. 27):

A finalidade principal da epopeia é o prazer decorrente da admiração das res gestae, "coisas feitas" que efetuam o kleos ou a fama, como se lê na definição do gênero que Horácio formula na Arte Poética: "Res Gestae regumque, ducumque, et tristia bella" [Coisas feitas dos reis e dos chefes e tristes guerras]. De Aristóteles até o século XVIII, o gênero é doutrinado como discurso longo, quase sempre em verso heroico, o hexâmetro datílico grego e latino, ou na oitava rima italiana de verso decassílabo com as seis primeiras rimas alternadas e as duas últimas emparelhadas (ABABABACC) das línguas vulgares, imitando por modo misto, narrativo e dramático, a ação una, inteira e perfeita, de tipo superior, ilustre ou heroico, metido em guerra histórica ou mítica, real ou fictícia, para a admiração, o prazer o ensino de virtudes cívico-morais.

A narrativa se abre em estilo pomposo e elevado. A esquadra liderada por Afonso Albuquerque topa, logo aos primeiros versos do Canto I, com uma criatura horrenda que tem escamas de cobra e cospe fogo como um dragão. Associado ao inferno, o ser discorre virulentamente contra a tripulação e, a seguir, metamorfoseada em Netuno (o que contrapõe a curvilínea figura mitológica à suposta retidão católica), agita o mar e provoca terror nos marinheiros. O episódio é triplamente oportuno: desperta a atenção do leitor, impressionado pelo locus horrendus; faz ressaltar o herói que enfrenta o temor

195 "Com este doce Império a Afonso seguem / Dois Sanchos, três Afonsos, e um Dionísio, / Afonso o bravo, e Pedro o justiceiro, / Que a fama leva, com a mesma glória, / Ao templo inalterável da memória" - Canto II (MELO, 1759, p. 48). 
da procela196; e anuncia uma dentre as criaturas monstruosas que aparecerão em outros cantos, o que colabora na unidade temática do poema:

Espalhadas as naus pelo destino Dos ventos e do mar, sem rumo ou tino Ao arbítrio se entregam da tormenta: Porém o invicto HERÓl [a]inda sustenta Aquele coração nunca vencido De nenhum desfavor, nenhum partido e Sempre como firmíssima coluna Nos giros mais violentos da fortuna. (MELO, 1759, p. 15).

Diante do monstro que tumultua os mares e os ânimos, Afonso Albuquerque dirige o argumento mais imediato da Coroa aos céus, ao modo de prece, com vistas a assegurar a missão de levar o nome de Deus e a fé católica à Índia - terra submetida ao jugo de Maomé e aos mandamentos daquela religião. A teologia se funde à política expansionista e relembra os antigos preceitos da guerra justa ${ }^{197}$, que vigoravam desde o tempo das Cruzadas, empreendidas séculos antes pelos católicos:

Olhai, SENHOR, que a terra em que pretende Fundar a Lei da Graça o invicto Afonso É a mesma Província, onde tão claro Já fiz o vosso NOME, e o Santo LENHO Se arvorou nos altares contra o empenho Deste traidor antigo, que persegue No mar, furioso, o Capitão insigne: Da vossa glória espero que se digne Que ele vá renovar aquele culto e Que perturbou do Abismo o fero insulto, E que escurece em tudo quanto doma A torpe tirania de Mafoma.

\footnotetext{
196 Os versos de $A$ Conquista de Goa lembram o episódio também descrito no primeiro canto da Eneida: "[...] O temporal / já venceu o navio de llioneu, / mais o do forte Acates com um outro / em que Abas ia a bordo, mais aquele / em que seguia o venerando Aletes. / Todos se inundam de inimiga chuva / pelas fendas que abriam nos costados, / todos são dominados e se afundam" (VIRGílIO, 2012, p. 141).

197 Lê-se no Canto II: "Mais, que as armas, o rogo nos persuade / E nunca consentimos a insolência / De querer sujeitar-nos a violência" (MELO, 1759, p. 46). António Manuel Hespanha (2006, p. 199) observou que: "Nos séculos XVII e XVIII, a teologia moral atinge um alcance e uma finura de análise casuística impressionantes. Estamos - pelo menos no Sul da Europa, perante uma sociedade 'integrista', em que se visa - apesar de uma certa laicização do pensamento teológico operado com a escolástica tomista - uma direção integral da vida inspirada na moral cristã e em que, portanto, os atos mais mínimos e mais íntimos estão detalhadamente regulados, quase não havendo lugar para ações indiferentes do ponto de vista do destino sobrenatural de cada um. Este ambiente integrista explica também a influência do discurso teológico sobre outros universos normativos, como designadamente, o direito secular".
} 
(MELO, 1759, pp. 17-18).

Provavelmente por ser uma súplica consistente que emana do herói, é o próprio Deus que lhe responde, numa das passagens mais cifradas do poema:

\begin{abstract}
Não presumas (responde a VOZ ETERNA
DA SUPREMA DEIDADE) que disponho

Outra coisa, contrária ao grande intento

De que o berço do Sol se santifique;

Bem que vejas as naus já quase a pique

Com o impulso infernal, não se concede

Ao Tártaro dragão, que agora mede,

Com esta inútil fantasia, os mares,

Que tenham desafogo os seus pesares

Na Católica esquadra: Se consinto

Que combata no undoso labirinto

Tão esforçado alento, lhe preparo

Nesta fadiga o Espírito preclaro.

Com que já se destina tanta glória

Aos brilhantes arquivos da memória:

Sem trabalho, sem juízo, sem tormento, Não pode haver ilustre vencimento.

(MELO, 1759, p. 19).
\end{abstract}

O discurso celestial, confirma a disposição sublime em levar a religião católica ("se santifique") ao Oriente ("berço do Sol"). Para isso, autoriza que Afonso Albuquerque lute contra as forças infernais no mar ("Consinto que combata no undoso labirinto"), onde forjará o éthos heroico ("já se destina tanta glória”), de que despontarão sabedoria ("Espírito preclaro"), entre mais virtudes, e legará seus feitos extraordinários à história (em "brilhantes arquivos da memória"). A réplica de Deus não se dirige apenas ao herói; elenca, para o catolicíssimo e discreto Rei Dom José I, os motivos que constituem o gênero épico - como sugere o dístico final, em que enuncia as causas ("trabalho", "juízo", tormento") que viabilizam a "ilustre” vitória.

Transcorrida a violenta tempestade, que quase levara ao naufrágio da armada lusitana, "Pacificou a esfera o seu semblante, / Ficando, sem o horror do impulso obsceno, / Todo o mar estanhado, e o Céu sereno" (MELO, 1759, p. 20). No excerto, a descrição do mar como superfície clara e homogênea ${ }^{198}$ retoma um dos lugares-comuns

\footnotetext{
198 Lemos no Canto VIII, Estrofe 73, V. 5, de Os Lusíadas: “Rompendo a força do líquido estanho" (CAMÕES, 2008 [1572], p. 199); na Prosopopeia: "As luzentes Estrelas cintilavam, /E no estanhado Mar resplandeciam, /Que, dado que no Ceo fixas estavam, / Estar no licor salso pareciam" (TEIXEIRA, 1977
} 
empregados na tradição épica portuguesa, em empréstimo aos poetas latinos, o que evidencia a imitação de modelos por Francisco de Pina e Melo. "Estanho" também era um dos verbetes encontrados no Vocabulário Português e Latino, publicado em 1712 por Rafael Bluteau ${ }^{199}$.

Afora isso, a alternância entre procela e calmaria atende a um dos pressupostos explicitados pelo próprio Pina e Melo, ao discorrer sobre a feitura e feição da epopeia, de que era preciso mexer com as paixões do leitor, comovendo-o. Também nessa perspectiva, alternam-se os sentimentos de Afonso Albuquerque. Inicialmente, o abatimento do herói - que supunha ter perdido os companheiros da jornada - leva-o a tecer metáforas enquanto vislumbra a paisagem que se aproxima, à proporção que as "quatro naus" restantes chegam à praia:

Mais que na horrível costa em que se via, Com alta dor, Afonso refletia Na perda dos amados Companheiros: Fingem-se ao longe os bárbaros outeiros, Como toscos gigantes, que assaltavam A morada Celeste: Reforçavam Tanto arrojo a eminência dos rochedos Que entre os rudes, inóspitos enredos De emaranhados bosques, descobriam A inchada presunção com que subiam Mostrando na fiç̧ão de tanto alento, Que era à soberba igual o atrevimento. (MELO, 1759, p. 21).

Da tristeza passa-se ao "júbilo". Após reencontrar as demais embarcações, que haviam aportado à terra por outra margem, e celebrar o reencontro com os marinheiros, Afonso Albuquerque manda afixar o "católico lenho" nos navios e instalar aras para sacrifícios, ao modo como fizera Noé:

Assim o fez Noé, assim Afonso, Depois de haver lutado com os mares:

Ambos de um alto impulso socorridos,

[1601], p. 39). Em nota ao Livro XI de Os Mártires, encontra-se esta nota de Filinto Elísio (1839, p. 127): “Depois que Virgílio chamou stagnum ao Mar, afoitou-se Camões a dar-lhe o nome de líquido estanho. Os Mareantes dizem ainda água estanhada, ou Mar leite, o Mar plano e liso como espelho".

199 “[...] quer Manoel de Faria dar a entender que com atenção chamou o nosso Poeta ao mar líquido estanho, por ser a água do mar mais pesada que as outras, assim como o estanho, depois do ouro, é mais pesado que os outros metais. Nos Autores Latinos não achamos a água comparada com outro metal,que com a prata. Ovídio diz Fons argenteus. Por líquido estanho poderíamos dizer liquidu marmor, pois diz Virgilio, Georgic.I. Infidum remis impellere marmor" (BLUTEAU, 1712, p. 310). 
Ambos a tanto empenho agradecidos.

(MELO, 1759, p. 24).

A equiparação com a personagem bíblica é engenhosa. Além de espelhar a vitória de Albuquerque naquela do mensageiro de Deus, descrita no Antigo Testamento, reinventa-se a origem do herói português, conferindo-lhe atributos encontrados nas Escrituras. Afonso Albuquerque é pintado como figura extraordinária, à altura dos eventos que empreende e dos perigos que enfrenta. Com estatura tão superior, a sua existência se liga diretamente à genealogia mosaica e, por extensão, aproxima o reino português dos impérios que povoavam as mais remotas eras judaico-cristãs.

Instalando-se na vila, chegam notícias de que as terras são habitadas por seres gigantes adornados com pedras valiosas. A representação desproporcional dos habitantes nos remete a Polifemo, de Odisseia, e a Adamastor, de Os Lusíadas ${ }^{200}$. Além de retratar imagens similares, com que reconstitui figuras de auctoritates, o episódio pode sugerir outros sentidos, relacionados às adversidades, mas também à superação de provas, durante a empresa em curso. Por sinal, o encontro entre os navegantes e a nação "inculta" começa em bons termos:

Sossega deste assombro, que te move Um impulso mais fero, que o de Jove:

Tudo em nó é cortejo, e é tudo empenho

De um festivo argumento que medita

A excelsa admiração desta visita.

(MELO, 1759, p. 39)

O Rei que governa o território entabula um discurso que traduz a intenção de estabelecer amizade com os viajantes:

Deidades sois, ó nobres Lusitanos,

Bem que homens pareceis: Esta estatura,

Que tanto nos disforma, e desfigura,

Não a reputo já por excelência:

Agora me parece a corpulência

Uma monstruosidade; e os vossos membros

Reconheço na boa simetria

\footnotetext{
200 De acordo com Cleber Felipe (2020, p. 117), “Gama reage frente aos perigos vaticinados pelo gigante inquirindo: 'Quem és tu? Que esse estupendo / Corpo, certo, me tem maravilhado' (Cam. Lus. V, 49). Neste instante, ocorreu uma reviravolta na narrativa e Adamastor deixou de assustar os nautas como antes. A partir do momento em que ele se identifica como o 'Cabo das Tormentas", passa então a ser conhecido, e deixa de ser exótico, de ser novidade'."
} 
Da justa proporção: Eu me fingia

Quanto maior, mais régio, e venturoso;

E hoje estou persuadido, que se os Numes

Houvessem de tomar a forma humana,

Só seria a da gente Lusitana.

(MELO, 1759, p. 42).

O primeiro canto se encerra quando o Rei estrangeiro pede a Afonso Albuquerque que relate a origem e os feitos da armada portuguesa. Interessa notar que a acolhida pacífica dos lusitanos pelos habitantes não estava longe dos relatos de outros reinos sobre os nativos da América, que chegavam à Coroa portuguesa desde meados do século XVI. O segundo canto se inicia com a resposta de Afonso Albuquerque ao Rei: "Queres, ó Rei, que q'eu diga a nossa origem / (Principia o Herói) nossos costumes, / Nossos ritos, e leis, nossas empresas" (MELO, 1759, p. 43). A exemplo do que acontece ao longo dos dez cantos de A Conquista de Goa, o episódio é sustentando por exemplos de Virgílio - "Infandun Regina jubes" - e Camões - "Mandas-me ó Rei que conte, declarando / De minha gente a grã genealogia -, ambos transcritos no rodapé do poema. Principia a longa resposta. Albuquerque, conhecedor das fórmulas que simulam modéstia, declara-se menor que a matéria:

Quisera q' outro houvesse que as contasse Com mais pompa e estilo, e te informasse Com a voz de um espírito facundo De como a nossa fama gira o Mundo, Pois a minha expressão não desconhece, Que a boca em louvor próprio se envilece. (MELO, 1759, pp. 43-44).

Durante o relato, Albuquerque situa o reino lusitano no Ocidente e afirma que Deus teria escolhido esse povo por adorá-lo:

Este DEUS, que na Cruz sofreu a morte. Por nos remir dos laços de um tirano,

É o que adora o Povo Lusitano: DEUS supremo, piedoso, imenso, forte, Justo, afável, terrível, e clemente, Que não quer outra Fé mais, que a Romana, Nem que tenha outro Deus a gente humana. (MELO, 1759, p. 45). 
As muitas virtudes que Afonso Albuquerque atribui ao povo português emanariam da luz da graça e da magnanimidade dos monarcas: "Dos nossos Reis mais filhos, que vassalos / Todos os Portugueses se reputam" (MELO, 1759, p. 47). Graças a essas virtudes, os lusitanos acumulariam conquistas, enumeradas minuciosamente pelo herói, inclusive a primeira viagem de Vasco da Gama às Índias, e o industrioso "achamento" das partes que viriam a ser chamadas de Brasil:

\author{
Vinte dias lutaram com as ondas \\ Os insignes varões, tendo sorvido \\ Quatro naus as hidrópicas voragens \\ Sem saberem do rumo, em q' se achavam, \\ Uma nova Província descobriram \\ Incógnita aos pilotos; onde viram \\ Outra gente, outro céu, outro terreno: \\ Acabou de se pôr o mar sereno; \\ E ali respiram todos da fadiga, \\ Do trabalho, do espanto, e dos insultos \\ Da horrenda tempestade: Estes incultos, \\ Inóspitos desertos, que hoje formam \\ Do Mundo a quarta parte, têm o nome \\ Então de Santa Cruz; mas a abundância \\ Das árvores purpúreas, q' na estância \\ Dos seus bosques, o clima frutifica, \\ Com o nome do tronco a terra explica, \\ E do comércio o provido ditame \\ Lhe quis chamar Brasil, sem outro exame \\ (MELO, 1759, pp. 66-67).
}

Dentre as qualidades do povo português, representado por Afonso Albuquerque, está a gratidão àqueles que lhe dão guarida e abrigo. O Canto II se encerra com estes versos do herói lusitano, ao Rei local:

Permite que aqui hoje reparemos

As destroçadas naus: Divulgaremos Tanta clemência em toda aquela parte, A que o irado Netuno, e o fero Marte Levar as nossas armas e o teu nome Entre os jaspes, que o tempo não consome, Servindo de esplendor ao claro templo, Inda mais, do que ornato, seja exemplo. (MELO, 1759, pp. 79-80). 
Assombrado com a eloquência de Albuquerque, o anfitrião conclui: "Vós não moveis a bélica potência / Senão onde encontrais a resistência" (MELO, 1759, p. 81-82). O poema reitera a vocação pacífica dos portugueses e a relação, supostamente harmoniosa, que estabelecem com outros povos, inclusive os gentios. Tanto na palavra, quanto nas armas, A Conquista de Goa reforça o contorno virtuoso dos lusitanos, traçado com apoio da genealogia de seus intrépidos desbravadores. Concluído do diálogo entre herói e rei, acordados os termos entre conquistadores e gigantes, o trabalho para reparo das embarcações é interrompido com a notícia de que haveria criaturas infernais na floresta - "Todos aqueles, que os gigantes ouvem, / O bosque acometeram" (MELO, 1759, p. 86).

Essa será a principal matéria do terceiro Canto, em que o poeta reedita a alternância entre locus amoenus e locus horrendus, depois de os portugueses terem feito aquele território de porto. Irmanados portugueses e nativos, uma parte da esquadra permanece no "Reino de Hunnatilpha" (MELO, 1759, p. 120); a outra, segue na descoberta de outros territórios. No canto seguinte, gigantes e lusitanos serão surpreendidos pelos mouros, que combaterão juntamente, logrando êxito:

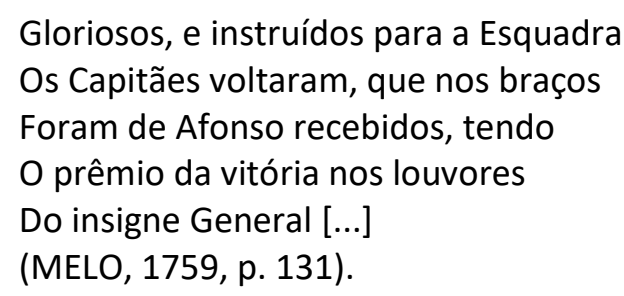

Entre tormentas e calmarias, batalhas e repastos, há uma constante no poema: onde quer que a armada liderada por Afonso Albuquerque chegue, os povos confrontados são convertidos: pelo argumento ou pela força:

Sabendo[,] pois[,] Afonso que Quinele Já se achava instruído nos prodígios Da nossa Santa Lei; se lhe prepara A sagrada ablução: Com pompa rara Quer o HERÓl se celebre este Mistério (MELO, 1759, p. 144). 
Em meio às renhidas batalhas, o decoro ${ }^{201}$ que caracteriza o discurso sublime é transplantado à indumentária com que o herói bravamente enfrenta o inimigo:

Cabeça, adarga, e peito ao mesmo instante

Parte só de um impulso; o HERÓl sustenta

A batalha no braço, e no decoro

Até que a resistência não podendo

Com o peso do esforço Lusitano,

Volta as costas à glória da defesa,

E nos deixa nas mãos a Fortaleza

(MELO, 1759, p. 162).

A morte de Dom Antônio de Noronha, primeiro Conde de Linhares, sepultado ao final do Canto V, prostra os companheiros de aventura. Porém, segundo a bipartição do poema, o desânimo cede ao vigor. No canto seguinte, a tristeza e as dificuldades materiais que enfrentavam os tripulantes ganha novo alento, com a notícia que novas armadas portuguesas se aproximam, em prol da conquista. Do sexto ao décimo canto, a narrativa é preenchida pelos avanços e recuos, êxitos e perdas dos portugueses, em parceria com o indiano Timoja, até que conseguem vencer tanto os mouros quanto as figuras infernais - possivelmente alegorias das religiões inspiradas na cartilha do demônio, segundo a perspectiva católica.

Após negociar o apoio dos companheiros, visando a um mesmo e maior objetivo, Afonso Albuquerque questiona a validade do empreendimento, o que ratifica a fusão entre fundamento teológico e interesse político ${ }^{202}$, que constitui o argumento central do poema:

Que importa que o valor, e a força acuda

A prosperar o impulso, senão obra

A Vontade divina? De que ferve

Que arrojado se empenhe o esforço, e a arte,

Se DEUS não estiver da nossa parte?

(MELO, 1759, p. 220).

201 “Um assunto cômico não quer ser desenvolvido em versos trágicos" (HORÁCIO Apud TRINGALI, 1993 p. 29).

202 "Em seu livro Conquista Espiritual do Oriente (1638), o frade franciscano Paulo de Trindade, cronista macauense, escreveu: 'As duas espadas do poder civil e do poder eclesiástico estiveram sempre tão unidas na conquista do Oriente que raramente encontramos uma sem a outra. $O$ fato é que as armas só conquistavam por intermédio do direito que o Evangelho lhes conferia, e a pregação só era útil quando acompanhada e protegida pela força das armas" (BOXER, 2007, p. 95). 
Grande parte do Canto VIII é preenchida pelo discurso de Cornivel, em resposta ao pedido que Ihe fizera Afonso Albuquerque, no canto anterior. O interlocutor descreve o território, em extensão e nas propriedades que contém ("rebanhos", "relvas", "ribeiras"). No final, acontece um dos diálogos mais notáveis de A Conquista de Goa. Na gruta a que se recolhera o muçulmano, o monstro (misto de dragão e serpente, cuja forma fora anunciada no primeiro canto) sugere a capitulação aos portugueses:

Que Portugal domine esta Cidade: Que nela fique extinta a falsidade Do bárbaro Alcorão: E que se firmem Dos golfos Orientais no verde espelho Os luminosos brados do Evangelho, Que faremos com tanto empenho inútil? Não nos será melhor deixar a empresa, Que dar a conhecer mais a fraqueza Da nossa miserável repugnância? Não (responde Alfarami) tem constância. Tem ânimo, e valor: Nenhum assédio Se deixa, enquanto oferece algum remédio (MELO, 1759, p. 292).

O mouro resiste. Ao embate retórico, seguem-se novas lutas pelo território. Como o poeta pretende ressaltar a constância e pertinácia do povo lusitano, comandado por Afonso de Albuquerque - digno sucessor das conquistas marítimas do reino português -, nada mais convincente (e conveniente ao gênero épico) que conceder maior vigor às palavras e à ação do inimigo. Haveria diversos elementos a considerar, para além do confronto verbal.

O diálogo acontece na caverna: ambiente que tanto pode remeter ao confronto entre Hércules e Caco - representado no oitavo canto da Eneida, de Virgílio ${ }^{203}$ - quanto ao episódio homônimo encontrado na República de Platão, a sugerir o embate em torno das imagens (ou concepções) ilusórias. Sob outra perspectiva, pode dar corpo monstruoso à maldade e ao modo sinuoso como pensam e agem os seguidores de Maomé, piores que serpentes (cuja simbologia talvez seja ainda mais óbvia). Também

\footnotetext{
${ }^{203}$ De acordo com Brunno Vieira (2007, p. 49), haveria "relações de sentido instauradas no confronto entre a narrativa mitológica de Hércules e Anteu (Luc. 4.589-665) e aquela de Hércules e Caco (Verg. Aen. 8.190-279), relações essas que evidenciam dois possíveis tratamentos da temática mitológica na tradição épica latina".
} 
poderíamos mencionar o dragão infernal e o imaginário cristão sobre os animais que pareciam brotar do solo, como se vê no Livro do Apocalipse.

Além da provável motivação alegórica, será oportuno ler e compreender a epopeia de Francisco de Pina e Melo como registro e celebração dos feitos portugueses - sabidamente empreendidos sob a luz da graça e o brilho da moeda e, em tese, justificados pela intenção de levar a fé reta, única e verdadeira aos povos sugestivamente situados nas rotas comerciais que separavam a Península Ibérica das fortunas em madeira, açúcar, pedras e metais preciosos. De um modo e de outro, valeria o alerta da serpente, convencida da petulância que animava outros seres: "Nunca cuidei (...) que fosse tanta / A protérvia dos homens" (MELO, 1759, p. 293).

Não será descabido propor que a maior ou menor coerência que venhamos a atribuir ao poema também decorrerá de algum conhecimento e interpretação dos preceitos católicos, casados à política expansionista do vasto império português, implementada desde o início do século XV com a tomada de Ceuta, no tempo de Dom João I. Esses pressupostos, somados às notas (com versos de Virgílio a Camões) que permeiam todo o poema, permitem-nos afastar dos clichês que, ainda hoje, dogmatizam impressões pré-moldadas por antologistas de literatura luso-brasileira desde o início do século XIX. 


\section{Referências}

ACHCAR, F. Lírica e Lugar-Comum: alguns temas de Horácio e sua presença em português. São Paulo: Edusp, 1994.

ARISTÓTELES. Sobre a Arte Poética. Trad. Antônio Mattoso; Antônio Queirós Campos. Belo Horizonte: Autêntica, 2018.

BLUTEAU, R. Vocabulário Português, Latino [...] (D - E). Lisboa: Colégio das Artes da Companhia de Jesus, 1712.

BODIN de ANGEVIN, J. Les Six Livres de La Republique. Paris: Jacques du Puys, 1576 [PDF].

BOXER, C. R. A Igreja Militante e a Expansão Ibérica: 1440-1770. Trad. Vera Maria Pereira. São Paulo: Companhia das Letras, 2007.

BRAGA, T. História da Literatura Portuguesa, 4ํvol. Os Árcades. Lisboa: INCM, 1984.

BRITO, W. Do Estado: da Construção à Desconstrução do Conceito De Estado-Nação. Revista de História das Ideias, Universidade de Coimbra, Vol. 26, pp. 259-306, 2005.

CAMÕES, L. V. de. Os Lusíadas. In: Obra Completa. Rio de Janeiro: Nova Aguilar, 2008.

CASTANHEIRA TURACEM, F. [Frei Lucas de Santa Catarina]. Serão Político, Abuso Emendado, Dividido em Três Noites para Divertimento dos Curiosos. Lisboa: Oficina de Valentim da Costa Deslandes, 1704 [PDF].

CASTRO, A. P. de. Retórica e Teorização Literária em Portugal: do Humanismo ao Neoclassicismo. 2a ed. Lisboa: INCM, 2008.

CIDADE, H. Lições de Cultura e Literatura Portuguesas, 2ำ vol. Da reação contra o Formalismo Seiscentista ao Advento do Romantismo. Coimbra: Coimbra Editora, 1975.

ELíSIO, F. Os Mártires. In: Obras, vol. XV [Nova Edição]. Lisboa: Tipografia Rolandiana, 1839.

FELIPE, C. V. do A. A Unidade Épica n'Os Lusíadas: revisitando Baco, Adamastor e o velho do Restelo. Revista Iberoamericana, v. XX, n. 73, pp. 107-127, 2020.

HANSEN, J. A. Autor. In: JOBIM, José Luis. Palavras da Crítica: tendências e conceitos no estudo da literatura. Rio de Janeiro: Imago, 1992, pp. 11-43.

. Notas sobre o Gênero Épico. In: TEIXEIRA, Ivan (org.). Épicos. São Paulo: Edusp/Imprensa Oficial, 2008, pp. 17-91.

HESPANHA, A. M. O Direito dos Letrados no Império Português. Florianópolis: Fundação Boiteux, 2006. 
ISUANI, E. A. Três Enfoques sobre o Conceito de Estado. Revista de Ciências Políticas, Rio de Janeiro, v. 27, n. 1, pp. 35-48, 1984.

MELO, F. de P. e de. A Conquista de Goa. Poema Épico. Coimbra: Real Colégio das Artes da Companhia de Jesus, 1759 [PDF].

OLIVEIRA, C. J. de. Tratado do Sublime de Dionísio Longino. Lisboa: INCM, 1984.

RUIZ, R. Francisco de Vitoria e os Direitos dos Índios Americanos: a Evolução da Legislação Indígena Castelhana no Século XVI. Porto Alegre: EDIPUCRS, 2002.

SARAIVA, A. J.; LOPES, Ó. História da Literatura Portuguesa. 17ạ ed. Porto: Porto Editora, 1996.

TEIXEIRA, B. Prosopopeia. 9a ed. São Paulo: Melhoramentos, 1977.

TEIXEIRA, I. Mecenato Pombalino \& Poesia Neoclássica: Basílio da Gama e a Poética do Encômio. São Paulo: Edusp, 1999.

TRINGALI, D. A Arte Poética de Horácio. São Paulo: Musa Editora, 1993.

VERNEY, L. A. Verdadeiro Método de Estudar, Vol. II. Lisboa: Livraria Sá da Costa, 1950.

VIEIRA, B. V. G. Mito e tradição literária na luta entre Hércules e Anteu: Farsália, 4.589 665. Revista Clássica (Soc. Bras. De Est. Cláss.), vol. 20, n. 1, pp. 46-63, 2007.

VIRGÍLIO. Bucólicas / Geórgicas / Eneida. Trad. Agostinho da Silva. Lisboa: Círculo de Leitores, 2012. 


\title{
Marquês de Pombal, Arauto do Segundo Império (brasileiro)?
}

\author{
"O pôr gente de distinção nestas vilas \\ me tem dado um grandíssimo cuidado» \\ (Francisco Xavier de Mendonça Furtado) ${ }^{204}$
}

«Seria um grande erro para com todos os princípios da Historiografia pragmática, se se desprezassem as forças dos indígenas e negros importados» (Karl von Martius) ${ }^{205}$

Resumo: Ao longo do século XIX, a quase totalidade dos manuais dedicados à História do Brasil auxiliou a construir, disseminar e sedimentar uma imagem francamente positiva e modernizadora de Sebastião José de Carvalho e Melo, supervalorizando os "acertos» e minorando os «excessos» praticados, ou atribuídos, ao Ministro de D. José I. Neste artigo, analisa-se de que modo a controversa figura de Pombal passou a ser incorporada à historiografia oficial da Nação brasileira, a partir de pressupostos ideológicos acordados pelos sóciosfundadores do Instituto Histórico e Geográfico do Brasil (desde o final da década de 1830), sob a proteção e patrocínio do imperador D. Pedro Il. A validação do Conde de Oeiras, especialmente nos materiais didáticos, obedecia a uma concepção teleológica de fazer história no Brasil. Por sinal, esse método persiste em diversos autores de nosso tempo, apesar das descobertas registradas pela historiografia, ao longo dos séculos XX e XXI.

Palavras-Chave: Historiografia; Marquês de Pombal; História do Brasil.

Abstract: Along the nineteenth century, almost all manuals concerning to the Brazilian History helped to build, disseminate and sediment a frankly positive and modernizing image of Sebastião José de Carvalho and Melo, overestimating the "hits" and reducing the "excesses" practiced by the Minister of the King D. José I. In this article, we analyze how Pombal's controversial figure was incorporated into the official historiography of Brazilian Nation, based on ideological assumptions agreed upon by the founding partners of the IHGB (since the late 1830s), under Emperor D. Pedro II protection and patronage. The validation of Conde de Oeiras, especially in didactic materials, obeyed a teleological conception of how to make history in Brazil. By the way, this method persists in several authors of our time, despite the discoveries recorded by historiography, throughout the twentieth and twenty-first centuries.

Keywords: Historiography; Marquês de Pombal; Brazilian History.

\section{Retroprojeção}

O Brasil, que supomos conhecer, também é obra de um conjunto de discurso(s). Mais do que pensar o território, que foi Ilha de Vera Cruz, Terra de Santa Cruz, e nome de uma commodity, desde o início do século XVI, a história do país está marcada de

\footnotetext{
${ }^{204}$ Carta do Governador e Capitão-General do Estado do Grão-Pará e Maranhão ao Secretário de D. José I, em 22 de novembro de 1755 (Mendonça, 2005, p. 54).

205 «Como se deve escrever a História do Brasil», 1956, p. 442. Sou muito grato a Patrícia Valim por ter recomendado a leitura desse ensaio de Karl von Martius - discutido adiante.
} 
modo indelével pela ocupação de diferentes lugares, sob variadas modalidades, por povos originários, ludibriados por estrangeiros especializados em rapinagem de terras a que se atribuiu a denominação de "Partes» do Brasil; depois, "Estados» da Coroa portuguesa; «Pátria»; e, finalmente, "Nação» - em tese, moderna, soberana e independente.

Felizmente, os estudos de Alan Manchester (1933), Nelson Werneck Sodré (1965) e H. E. S. Fisher (1971) revelaram, com fartura de provas, o que parte da historiografia brasileira ainda desconhece ou a que finge não conceder importância. A independência política, proclamada em 1822, é uma questão controversa e demandaria cuidadosa reflexão, pois também diz respeito a ambivalências encontradas na historiografia sobre um país que, até bem pouco tempo, estava a discutir a identidade brasileira (ou a projeção dela, a depender dos interessados). A esse respeito, um notável ponto de inflexão pode ser percebido em Brasil: mito fundador e sociedade autoritária, autêntico contraponto à celebração dos quinhentos anos da história do país. Nele, Marilena Chaui (2000, p. 16) observava que:

A partir do século XVIII, com as revoluções norte-americana, holandesa e francesa, «pátria» passa a significar o território cujo senhor é o povo organizado sob a forma de Estado independente. Eis por que, nas revoltas de independência, ocorridas no Brasil nos finais do século XVIII e início do século XIX, os revoltosos falavam em «pátria mineira», "pátria pernambucana», "pátria americana»; finalmente, com o Patriarca da Independência, José Bonifácio, passou-se a falar em «pátria brasileira». Durante todo esse tempo, «nação» continuava usada apenas para os índios, os negros e os judeus.

Para aferir credibilidade ao discurso sobre a constituição da memória nacional, tanto as letras quanto a história, a geografia e outras áreas do saber foram acionadas, desde a década de 1830. Um prenúncio disso aconteceu em 1826, quando Ferdinand Denis escreveu sua história da literatura brasileira, e Almeida Garrett defendeu a substituição dos modelos europeus pelo herói que representasse o espírito e a coloração do Novo Mundo. Daí a eleição do índio como aparente símbolo nacional, tanto por intermédio da literatura, quanto da história.

Como é largamente sabido, as recomendações de Denis e Garrett repercutiram sensivelmente nos primeiros ideólogos da Nação brasileira. Em 1836, um grupo de jovens, capitaneados por Gonçalves de Magalhães e Araújo Porto Alegre, que circulavam 
em Paris havia alguns anos, editou dois números da Revista Niterói e dava início a uma série de obras, a exemplo de Suspiros Poéticos e Saudades, que, dentre outras coisas, tematizavam as virtudes do índio e atrelavam a sua imagem à composição de uma poesia de teor nacionalizante.

Esses gestos (teoricamente patrióticos), celebrados em Paris, antecedem uma série de providências adotadas pelos representantes da Regência e Império brasileiros, para fabricar uma memória do que viria a ser uma versão positivada da história brasileira, com vistas a dar consistência ao projeto civilizatório ${ }^{206}$. Um dos primeiros estudos a resgatar tais episódios subjacentes à memória nacional foi realizado por Maria de Lourdes Haidar, em 1972. Ela lembrava que:

Por Decreto de 2 de dezembro de 1837, converteu-se o Seminário de São Joaquim, antigo Seminário dos Órfãos de São Pedro, no modelar colégio de instrução secundária que, numa homenagem ao futuro imperador, recebeu o nome de Pedro II. O Colégio dos Órfãos de São Pedro datava dos tempos coloniais (Haidar, 2008 [1972], p. 96).

Outro estudo decisivo para se compreender melhor a instauração do discurso nacionalista, ao final da década de 1830, é o de Lucia Maria Paschoal Guimarães (Debaixo da imediata proteção imperial), resultado de sua tese de doutorado, veiculada pela Revista do IHGB, em 1995. A pesquisadora salientava que:

Em meio a tantas crises institucionais e às notícias de revoltas que agitavam o país, a Corte do Rio de Janeiro assistiu, no decorrer de 1838, à instalação de dois importantes centros da Memória Nacional. O primeiro, o Arquivo Público, criado em 2 de janeiro daquele ano, por ato do Ministro Bernardo Pereira de Vasconcellos. O segundo, o Instituto Histórico e Geográfico Brasileiro, constituído meses mais tarde, em 21 de outubro, tratava-se de um empreendimento de caráter privado, que contava com o patrocínio da Sociedade Auxiliadora, por iniciativa do Marechal Raymundo José da Cunha Mattos e o Cônego Januário da Cunha Barbosa, que justificavam a nova instituição alegando o seu caráter

\footnotetext{
206 «No seu empenho para manter a Ordem e difundir a Civilização, os dirigentes imperiais forjaram instituições, copiaram outras, criaram um corpo de leis, esforçaram-se por difundir as Luzes. À maneira das "Nações Civilizadas", deram particular importância à organização da Instrução Pública [...] O primeiro regulamento do Colégio [Pedro II], editado em 1838, seguia o modelo francês, determinando estudos simultâneos e seriados, porque até então o ensino secundário na Corte estava organizado em aulas avulsas» (Mattos, 2000, pp. 33 e 43). «O ensino de História do Brasil está intimamente relacionado ao Colégio Pedro II, instituição criada como estabelecimento oficial do ensino secundário para atender às necessidades de formação de uma elite social, para a qual o projeto civilizatório do Império era especialmente dirigido. [...] A disciplina História teria um importante papel na consolidação do Estado Nacional: o de contribuir para forjar a nacionalidade brasileira» (Santos, 2011, p. 51).
} 
pedagógico, posto que se destinava a «ministrar grandes auxílios à administração pública e ao esclarecimento de todos os brasileiros» (Guimarães, 2011, p. 33).

Aceita a hipótese de que a concepção do Brasil se atrelava à reconstituição interessada de seu pretérito, deve-se recordar que certa historiografia obedece a determinadas perspectivas e recorre a métodos de persuasão, com vistas a sensibilizar o leitorado. Em nosso caso, a tarefa ficou a cargo de um conglomerado de intelectuais que sustentavam, ideológica e financeiramente, o IHGB. Valdei Lopes de Araújo (2008, p. 176) salienta que:

\begin{abstract}
Mesmo admitindo tratar-se de uma tarefa coletiva, Cunha Barbosa não hesitou em estabelecer, desde o início, a escrita de uma História Geral como um dos objetivos centrais do IHGB. Como na "Sociedade dos Acadêmicos Renascidos», tratava-se de um empreendimento coletivo e coordenado, mais do que um gesto de autoria individual. Dividida a história do Brasil em épocas, ficaria mais fácil coordenar o trabalho dos diversos membros. Por isso, o esforço inicial era definir os limites de cada época e os fatos principais a serem relatados. O fundamental era que o programa de uma História Geral partia do pressuposto da preexistência de uma totalidade histórica.
\end{abstract}

\title{
Pombalismo
}

$\mathrm{Na}$ «5 $\underline{a}$ » edição «revista e atualizada» da História do Brasil, de José Francisco de Rocha Pombo (1857-1933), publicada em 1948, há um «Prefácio» sem identificação que enaltece "o trabalho», a «modéstia» e o «amor à verdade» do autor paranaense. A certa altura, o leitor se depara com um subcapítulo intitulado "A obra do Marquês de Pombal», que comporta afirmações vizinhas do anedótico: «D. José I era uma criatura perfeitamente medíocre, de todo incapaz de ação, e só tendo gosto para os regalos e as aventuras escusas. Deu graças quando longo encontrou um homem a quem entregar o reino» (Rocha Pombo, 1948, p. 307).

Quer dizer, embora as premissas anunciadas no paratexto reafirmassem o comprometimento do autor e a veracidade do que ia no livro, a seção dedicada a Pombal repisava um conjunto de hipóteses questionáveis, construídas desde o início do século XIX, no país. Afora isso, os elogios à destreza e ao caráter enérgico do Primeiro Ministro implicavam o apagamento do Rei e lhe atribuíam postura, no mínimo discutível. A suposta letargia e carolice de José I contrapunha-se ao dinamismo e à força do 
Secretário do Reino, que teria assumido o comando virtual da Coroa desde que colocado à prova por ocasião do terremoto lisboeta de 1755 .

O historiador respalda-se na tradição e se filia à auctoritas do gênero em que escreve a sua versão dos acontecimentos. Escorado no historiador inglês Robert Southey, Rocha Pombo sustentava que «[Pombal] possuía em alta dose o orgulho nacional que distingue os portugueses, e tinha robusta fé nos seus próprios talentos e força de caráter» (Idem, ibidem, p. 309). Relevando o temperamento irascível e o caráter despótico das ações implementadas pelo Primeiro Ministro do Rei, o autor privilegiava seus feitos, isentando-o das controvérsias que cercavam o seu nome e comprometiam a sua imagem, como se se tratasse de um homem de éthos inoxidável, ponderado no proceder.

Essa visão condescendente de Sebastião José - nomeado Conde de Oeiras, em 1759, e Marquês de Pombal, em 1769 - foi marca registrada de certa concepção que pautou os livros didáticos produzidos no Brasil entre meados do século XIX e a segunda metade do século XX. É o que se percebe claramente no Compêndio da História do Brasil, do general Abreu e Lima, editado em 1843 (pp. 234-235):

Apesar do quanto se imputa a Pombal, não era ele menos suscetível de conceber grandes ideias, de dispor com madureza vastos planos e de apressar a conclusão deles. Restabeleceu o comércio e a este respeito lhe deveu Portugal vantagens reais. Este Ministro, homem de Estado, não hesitou em atacar às claras os vergonhosos tratados concluídos com a Inglaterra [...]

Com pequenas variações, esse discurso embalou os manuais publicados décadas depois, sempre a validar as decisões a mando de Pombal, como se nota na oposição entre os interesses dos jesuítas e da Coroa portuguesa, no Compêndio de História do Brasil, do padre Raphael Galanti, publicado em 1896:

\footnotetext{
Mais tarde, porém, afirmam os mesmos autores, arrastados, os sucessores desses apóstolos [jesuítas], pela ambição e cobiça, começaram a proteger os índios, chegando até ao excesso de Ihes dizer que a terra era deles! Ofenderam deste modo os colonos cujos interesses prejudicavam, merecendo afinal serem expulsos pelo marquês de Pombal. Parece-nos, por conseguinte, do maior alcance para a história verdadeira estudar com alguma diligência a vida dos primeiros missionários elo nosso país ponderando suas relações com os índios e os colonos.
} 
Enquanto o general elogiava as ações de Pombal, com vistas a livrar a Coroa do jugo inglês - «Era por sábios regulamentos, e vivificando o comércio, que Pombal fazia florescer o Brasil» (Abreu e Lima, 1843, p. 236) -, o padre justificava a expulsão da Companhia de Jesus devido à suposta aliança simétrica entre índios e jesuítas. Escritos no intervalo de cinquenta e três anos, ambos os historiadores reiteravam que se tratava de relatos orientados pela verdade dos fatos. Evidentemente, não se tratava de manuais isentos, mesmo porque ambos interpuseram argumentos com o fito de persuadir 0 consulente sobre os benefícios econômicos e virtudes civilizatórias catalisadas pelo Primeiro Ministro de d. José I.

Um dos saldos dessa trajetória ufanista, antes do tempo, atribuída ao país através dos manuais didáticos ao longo de um século e meio, provavelmente cristalizou a imagem quase sempre positiva de Pombal, que passou de símbolo português a uma espécie de patriarca brasileiro antecipado. Não seria demasiado relembrar que o Brasil não existe como nação ${ }^{207}$, antes de 1822, como assinalam diversos historiadores. Em capítulo publicado recentemente, Vera Lucia Queiroz Andrade (2016, pp. 102 e 104) salienta o fato de que:

Durante o Império, desde o início da tarefa de construção da nacionalidade brasileira, o discurso de legitimação da monarquia levou políticos/intelectuais a formularem um projeto civilizatório de Nação, comprometido com o perfil identitário branco-europeu e cristão idealizado para os trópicos [...] A educação no Brasil monárquico teve seu lugar demarcado no projeto civilizatório do Império de consolidação do Estado/Nação, sendo concebida como instrumento social de moralização dos indivíduos, garantia da ordem e caminho para o progresso.

Sob esse aspecto, não haveria maior razão para enxergar em Sebastião José de Carvalho Melo papéis administrativos ou políticos que não lhe couberam, especialmente porque ele representava exclusivamente os interesses da Coroa portuguesa. Curiosamente, a atuação do Ministro de d. José I foi muitas vezes descrita como augúrio

\footnotetext{
207 «A constituição dessa biografia [da nação] é uma tarefa de gerações, de tal forma que ao passar do tempo, à força de constante repetição desde as primeiras letras até os bancos da universidade, com graus variados de acuidade e sofisticação, forjam-se determinados estereótipos, determinados temas que passam a ter um peso suficientemente marcante para dar consistência a um corpo que há pouco não existia. Aos poucos passa-se de hipóteses, suposições e afirmações, e a colônia é posta como antecedente da nação. Constroem-se histórias nacionais e uma "história geral" passa por um somatório dessas histórias nacionais. A partir dessa perspectiva a época colonial perde sua historicidade e passa a ser um 'momento' da história nacional» (Silva, 1997, p. 14).
} 
do Império brasileiro. Atrelado à historiografia nacional, Pombal foi equivocadamente retratado como anunciador do Brasil pós-independência: espécie de degrau histórico que teria acelerado o ritmo de Portugal, colocando-o em sincronia com as demais civilizações da Europa.

Séculos XIX e XX adentro, esse ideário positivo das Reformas Pombalinas foi reproduzido em diversos manuais de História do Brasil. Eis que o empenho de pesquisadores menos levianos (e mais responsáveis) ajudaram a rever criticamente a extensa documentação relativa à capitania das Minas Gerais, na segunda metade do Setecentos luso-brasileiro. O exame desses manuais comprova que, salvo louváveis exceções, foi especialmente a partir dos anos de 1970 que a imagem favorável a Pombal passou a ser colocada em questão pelos pesquisadores brasileiros.

Nesses casos, frequentemente os estudos realizados no país reverberavam o trabalho sério (e desprovido de lastro pseudonacionalista) realizado por historiadores estrangeiros, que induziram os pesquisadores daqui a rever os limites do ideário comtiano, a contradição entre o liberalismo econômico e o regime escravista, sem contar as fórmulas em louvor dos "avanços», no ensino, no comércio e na lei, atribuídos aos comandos do estadista português. ${ }^{208}$

Com vistas a discutir a imagem de Pombal, repisada ao longo do século XIX no Brasil, percorrem-se manuais didáticos, cujos conteúdos se relacionavam diretamente a atores descritos de modo grandiloquente que foram transformados em protagonistas a liderar episódios de alcance superestimado. Determinados homens e eventos passaram a adornar a História do Brasil com grandes feitos, a despeito de os autores proclamassem estar comprometidos com a fidelidade aos fatos, empreendidos pelo "espírito" de homens industriosos e teoricamente convictos, religiosa e politicamente.

Parece sintomático que, nesses manuais, a diç̧ão dos historiadores se aproximasse do discurso atinente às epopeias que circularam nos Estados do Brasil, Maranhão e Grão-Pará entre os séculos XVII e XVIII: dado que corrobora a necessidade

\footnotetext{
208 Dentre os primeiros trabalhos mais relevantes, que adotaram perspectiva crítica em relação ao período pombalino, assinalam-se As Reformas pombalinas da Instrução Pública, de Laerte Ramos de Carvalho (1952). Mais recentemente, destaca-se A Época Pombalina no mundo luso-brasileiro - coletânea organizada por Francisco Falcon e Claudia Rodrigues (2015) -, e a compilação Jesuítas e Ilustração: rupturas e continuidades, editada por José Eduardo Franco, Karl Heinz Arenz, Luiz Eduardo Oliveira e Maria Regina Barcelos Bettiol (2019) - que congrega numerosos pesquisadores oriundos de Portugal e do Brasil, pautados pela rediscussão do lugar e da atuação do poderoso ministro português.
} 
de reler os manuais com redobrada atenção, a fim de revelar determinados artifícios empregados pelos autores - teoricamente, ciosos de transmitir intenções sinceras ao consulente. Vejamos o que e como escrevia o romancista Joaquim Manuel de Macedo em 1860, ao assumir a cadeira de História do Brasil, no colégio Pedro II:

Os holandeses, apesar da má fortuna que tinham experimentado em 1625, não perdiam de vista o Brasil [...] entrou o audacioso almirante Pieter Hayn duas vezes no porto da Bahia, primeiro em 1627 e depois em 1628, tomando muitos navios mercantes, e naquele último ano, avançando para o recôncavo, onde em Peitinga, o valente capitão Padilha morreu combatendo contra ele (Macedo, 1898, p. 154)

Ao assumir a persona de historiador, Joaquim Manuel de Macedo recorre a adjetivos e advérbios, tanto para enaltecer o vício do invasor («audacioso almirante»), quanto para realçar a virtude do defensor português ("valente capitão»). A intercalação das frases, no parágrafo, permite ao autor acumular informações que considera relevantes (datas e nomes dos atores envolvidos), com o intuito não só de instruir os pupilos do colégio, mas persuadi-los de que os dados passaram pelo crivo da verdade. Quanto a Pombal, o professor atribui a ele evidente protagonismo, a referendar os seus feitos:

Falecendo D. João V a 31 de julho de 1750, sucedeu-lhe no trono de Portugal, D. José I, seu filho, que chamou ao seu conselho o célebre Sebastião José de Carvalho e Melo, ulteriormente conde de Oeiras e marquês de Pombal (neto de uma brasileira), notável estadista, cujo nome jamais será esquecido (Idem, Ibidem, p. 255).

Acresce que, se por um lado, a imagem positiva de Pombal servia ao propósito nacionalista de D. Pedro II a sugerir que o Estado brasileiro independente continuava a marcha evolutiva iniciada pelo então ministro de D. José I, por outro, escamoteava-se a tensão entre o espírito autoritário do estadista e as primeiros gestos ditos «libertários» (ou creditados como «revolucionários») no Brasil, meio século antes de o território vir a se constituir efetivamente como nação.

Ora, o primeiro equívoco relacionado aos manuais de história residia em considerar «nacional» o Estado do Brasil, décadas antes da emancipação oficial da antiga colônia portuguesa, graças ao forte empuxo inglês - como demonstraram Alan K. Manchester, em Preeminência inglesa no Brasil; Nelson Werneck Sodré, com As razões 
da Independência; e H. E. S. Fisher, no seu De Methuen a Pombal. ${ }^{209} \mathrm{O}$ segundo lapso metodológico estava em exprimir (quando não reproduzir) impressões sobre o estadista português sem, ao menos, consultar a vasta documentação que ele assinou.

\section{Revisão}

De extração humilde e origem incerta (Azevedo, 1990; Bessa-Luís, 1990; Maxwell, 1996; Branco, 2014; Chauvin, 2016), Sebastião José de Carvalho e Melo (16991782) foi alçado a fidalgo (e depois, nobre) por manobra dos familiares, conforme salientam seus biógrafos. Se nos manuais de maior extensão e fôlego, Pombal é retratado invariavelmente como promotor da monarquia, nos pequenos livros de história ele é figurado sumariamente, ao modo de uma caricatura às avessas, já que representado com sinal positivo. De maneira similar ao que aconteceu com os manuais de historiografia literária, o país foi pintado como nação pujante, econômica, política, cultural e socialmente, vocacionado para superar o estágio «medieval» e romper com a filiação a antiga matriz portuguesa, em direção ascendente rumo ao futuro da ordem e do progresso.

É ponto pacífico da historiografia crítica que a composição das Histórias do Brasil coincide cronologicamente com a fundação do IHGB, e adere ideologicamente ao empenho do Império em aferir caráter nacionalista ao discurso oficiado por um punhado de sócios, e demais protegidos, interessados em repercutir a propaganda imperial, o credo católico e dar vulto a certos protagonistas da historiografia nacional. Assim como

\footnotetext{
209 «Em 1580, Filipe II submeteu Portugal ao domínio espanhol, mas em 1640, o duque de Bragança iniciou uma revolta para libertar o seu país do controle da Espanha. Lisboa, lutando pela independência e perturbada pelos ataques dos holandeses às ricas pilhagens vindas das colônias, pediu auxílio à Inglaterra, e enviou uma comissão a Londres para negociar um tratado que reconhecesse a recém-proclamada [portuguesa]» (Manchester, 1973, p. 18). «Desde a data em que foi firmado, [o Tratado de Methuen] foi também combatido. Em Portugal, a gente do tempo não poupou os que se haviam envolvido nas negociações. Suspeitas de suborno foram divulgadas. [...] Severas críticas mereceu o tratado, mesmo em documentos oficiais, ainda ao tempo em que foi firmado. Entre elas, a que lhe fez o representante português em Londres, D. Luís da Cunha. Herdeiro das ideias do conde da Ericeira, partidário das opiniões de Colbert, D. Luís da Cunha manifestou-se contrário às facilidades concedidas ao ingresso dos panos ingleses em Portugal, onde prejudicariam o desenvolvimento das indústrias nacionais correspondentes» (Sodré, 1969, pp. 8-9). "A contribuição do Brasil para a 'revolução comercial' inglesa tem sido igualmente negligenciada pelos historiadores. Esta negligência resulta não apenas das estatísticas comerciais inglesas, que não registram qualquer comércio com o Brasil nem mostram a importância do comércio lusobrasileiro para o comércio entre Portugal e a Inglaterra, mas também das indicações superficiais da sua importância» (Fisher, 1984, pp. 22-23).
} 
a literatura brasileira constitui invenção do século XIX, que aventa ideias revolucionárias e sentimentos patrióticos antes do tempo - experenciadas por um punhado de atores de origem e mentalidade portuguesa -, os manuais de história do Brasil ajudaram a forjar um discutível continuum temporal e ideológico, em que episódios mais ou menos graves foram considerados marcos disruptivos e índices de evolução do povo.

Quer dizer, o que poderia ser compreendido como contradição da história portuguesa, durante o reinado de D. José I (1750-1777), passou a representar ações meritórias que espelhariam a transição entre o estágio colonial e o emancipado. Houve, nos manuais de história, uma espécie de «aclimatação» do ministro, quando não a sua incorporação ambivalente à pré-história do Brasil - anacronismo pretensamente justificado pelos eventos transcorridos meio século depois. De maneira geral, o estadista português tomava parte da historiografia do Segundo Império mediado pela sobrevivência dos indígenas, agora catapultados à condição de símbolo nacional. $\mathrm{O}$ Tratado de Madri, firmado em 1750, foi citado em todos os manuais de História do Brasil, que circularam no século XIX, como se vê nos Episódios de História, de J. C. Fernandes Pinheiro, editado pela primeira vez em 1859:

Profunda sensação causou nos gabinetes de Lisboa e de Madrid a conduta dos jesuítas. Incontestável era a sua influência sobre o espírito dos índios, e evidentes provas se haviam colhido que só deles partira a iniciativa e a direção da revolta. Sentava-se n'essa época no sólio lusitano $D$. José I, e guiava o baixel da monarquia o enérgico e ilustrado ministro marquês de Pombal, que de há muito anelava por abater o predomínio da Companhia, votando-Ihe profundo ódio. Como hábil político, aproveitou-se o poderoso ministro da oposição dos jesuítas ao tratado de 1750 para, adicionando-a a outras causas, fazer decretar a supressão da ordem em Portugal e suas conquistas pelo alvará de 3 de setembro de 1759 (Pinheiro, 1866 [1859], p. 167).

Preterido por D. João V, de acordo com seus biógrafos Sebastião José seria requisitado como Secretário do Reino por D. José I. Esse dado comparece a diversos manuais voltados para o ensino formal. Dado curioso, os excertos a seguir sugerem que determinadas informações foram replicadas em boa parte deles, talvez a espelhar o que era ensinado no colégio Pedro II - instituição paradigmática do ensino. Eis como Américo Brasiliense retrata a chegada de Sebastião José:

Morto D. João V, subiu ao trono D. José I. Seu reinado tornou-se notável pelos atos do seu ministro o marquês de Pombal. Foi este estadista que animou o comércio, formando companhias, rivais do monopólio inglês; atacou os tratados com a 
Inglaterra, promulgou medidas salutares, subtraiu Portugal à influência britânica. Confiou a repartição do sul do Brasil a Freire de Andrade, e a do norte a seu irmão. (Brasiliense, 1876, p. 118).

Publicada em 1854, a História Geral do Brasil, de Francisco Adolfo de Varnhagen ${ }^{210}$ talvez tenha inspirado os termos que apareceram nos demais manuais:

E havendo El-Rei D. José, por morte de seu pai D. João $V$, subido ao trono, meses depois de ratificar-se o tratado, [...] [chamou] a seus conselhos o célebre ministro Carvalho (que se achava em Lisboa de volta das suas missões em Londres e em Vienna), mais conhecido pelo título que depois teve de marquês de Pombal (Varnhagen, 1877, p. 915).

A formulação de Varnhagen parecia reverberar no manual de Antônio Alves Coruja:

Por morte de D. João V em 1750, Ihe sucedeu seu filho D. José I, cujo reinado se tornou memorável pela administração do Marquês de Pombal, a quem El-Rei muniu de grandes poderes, prestando absoluta confiança a seus atos. Se muito lhedeve- Portugal, e especialmente a cidade de Lisboa pelas suas enérgicas providências por ocasião do terremoto de que foi vítima em 1 으 de novembro de 1755; não menos Ihe deve o Brasil pela animação que' deu ao seu comércio, navegação, indústria e agricultura; e sobretudo pelas ordens e decretos que expediu em favor da liberdade dos índios, sua emancipação e manutenção de seus bens (Coruja, 1877, p. 133).

Com ligeira alteração na composição do retrato de Pombal, João Pedro Xavier

Pinheiro encontrou outro modo de referir o acontecimento:

Nos primeiros tempos do reinado de D. José foi o marquês de Pombal chamado à direção dos negócios públicos. Este estadista, famoso por eminentes talentos e ainda mais pelo fervoroso desejo de melhorar o seu país e tirá-lo do abatimento em que jazia, depois de atos em que provou sua alta capacidade, teve por conveniente e até necessário guerrear os jesuítas, os quais lhe antolhavam como um obstáculo aos seus desígnios (Pinheiro, 1880, pp. 277-278).

\footnotetext{
210 «O trabalho de Varnhagen pode hoje ser visto como uma busca da nação no Brasil de meados do século XIX. Acontece que, aqui, ao contrário do que acontecera na França, Inglaterra ou mesmo nos Estados Unidos, havia o Estado, mas a Nação ainda não tinha se organizado. A especificidade da colonização portuguesa, a rala presença de imigração de grupos familiares (que só começaria a ganhar peso em fins do século XIX), a continuação do trabalho escravo, a ausência de comércio interno significativo são alguns dos fatores que retardaram algo que se pudesse considerar uma nação no sentido moderno da palavra. Por outro lado, a emancipação política do Brasil dá-se de forma muito particular, liderada que foi pelo próprio filho do rei de Portugal e com a anuência deste, em 1822. Uma transição sem mudança, típica de um país que não reforma, concilia» (Pinsky, 2017, pp. 13-14).
} 
A seu turno, Luís Queirós de Mattoso Maia parecia fazer coro aos termos de Varnhagen:

A D. João V, falecido em 31 de julho de 1750, sucedeu seu filho D. José I, cujo reinado constitui uma das épocas mais importantes da história de Portugal, por causa da administração do célebre ministro Sebastião José de Carvalho e Mello, Conde de Oeiras (junho de 1759), e Marquês de Pombal (17 de setembro de 1770). Da mesma forma que Luís XIII em França tinha-se resolutamente confiado no tino político e administrativo do Cardeal Richelieu, assim D. José I, depois de ter reconhecido os dotes governamentais do seu ministro Carvalho e Mello, entregouIhe a direção da administração pública (Maia, 1891, p. 216).

Quase o mesmo se pode afirmar de Villa-Lobos, cujo manual apareceu alguns anos à frente.

D. José I sucedeu no trono de Portugal a seu pai D. João V, falecido a 31 de julho de 1750. A não ser sua luminosa ideia chamando o notável político Sebastião José de Carvalho e Mello, conde de Oeiras e depois marquês de Pombal, para fazer parte da administração de Portugal, ter-se-ia este país, antes de completar os 26 anos do seu reinado, despenhado no abismo para onde a passos largos caminhava (VillaLobos, 1896, p. 106).

Como se disse, os registros iniciais sobre a História do Brasil foram artigos veiculados pela Revista do IHGB (Instituto Histórico e Geográfico Brasileiro), no final da década de 1830. De modo geral, eles se pautavam pelo elogio do Império, em fidelidade com a Santa Igreja Católica e a forja da Nação, super endividada e recém independente. Com exceção de alguma ressalva, que Francisco Adolfo de Varnhagen registrara na primeira edição de sua História Geral do Brasil, em 1854, esse conjunto de ensaios parece ter orientado a diç̧ão dos autores que produziram manuais sobre o país, nos moldes prescritos por Karl von Martius ${ }^{211}$. Na síntese de Patrícia Valim (2007, pp. 126127):

A centralização política [...] passou a ser o objetivo prioritário para o Regresso conservador, estabelecendo-se, assim, instituições fundamentais para "corrigir» a orientação descentralizadora do período regencial. Nesse empuxo, criaram-se instituições como: o colégio Pedro II, o Arquivo Público do Império e o Instituto Histórico e Geográfico Brasileiro, em 1838 [...] tanto a literatura quanto a

211 «Nos pontos principais a história do Brasil será sempre a história de um ramo de portugueses; mas se ela aspirar a ser completa e merecer o nome de uma história pragmática, jamais poderão ser excluídas as suas relações para com as raças etiópica e índia» (Martius, 1956, p. 454). 
historiografia nacional, forjadas a partir do Rio de Janeiro, inserem-se num mesmo processo, segundo o qual os homens de letras procuração usar a cultura com objetivos práticos: organizar a hegemonia do Estado brasileiro e promover o progresso material da nação sem, contudo, tocar na questão do escravismo.

Hoje se sabe que a concepção dos autores passava pelo ideário defendido pelo Império e replicada pelos membros do IHGB, sob o olhar benévolo de D. Pedro II. De modo análogo ao que sucedia na literatura, a historiografia propagava os ideais defendidos pelo governo ${ }^{212}$. Portanto, no que diz respeito à escrita da história nacional, se a nossa intenção é situar a figura de Pombal com a maior precisão possível, seria imprescindível realizar um movimento duplo.

De um lado, haveria necessidade de revisitar os tratados, decretos, cartas e demais documentos atribuídos ao Ministro de D. José I. De outro, cotejar os manuais de história do Brasil, que circularam no país enquanto durou o regime Imperial, tendo em vista contrabalançar alguns estereótipos aderidos à imagem superestimada do estrategista e mecenas português. Essas e outras questões foram discutidas com parcimônia. Seria escusado lembrar a obviedade de que Pombal não previu a Independência do Brasil Colônia, nem aderiu aos portugueses nascidos no Estado do Brasil. Tampouco as reformas que capitaneou impediram que resquícios da mentalidade reinol portuguesa persistisse nos séculos subsequentes, em nome da mitra, do ouro e do trono. Até meados do século XVIII, ainda eram consideradas virtudes, os modos e artifícios que conferiam discrição aos súditos da Coroa. Como bem observa João Adolfo Hansen (2019, p. 104):

Agudeza, prudência, dissimulação, aparência e honra constituem a discrição. Nas monarquias absolutistas do século XVII, principalmente nas ibéricas, a discrição é padrão nuclear da racionalidade de corte que define o cortesão, proposto para todo o corpo político do Estado como o modelo do uomo universale, o homem universal, como dizia Castiglione no século XVI. Nas práticas de representação, a discrição é categoria intelectual que classifica ou especifica a distinção e a superioridade de ações e palavras, aparecendo figurada no discreto, que é tipo ou personagem dos processos de interlocução.

\footnotetext{
212 «Após o estabelecimento da agremiação no Paço Imperial, de fortalecer a figura do menino-imperador com pompa e circunstância através de comemorações dos natalícios imperiais, da cerimônia do beijamão, entre outras, os sócios do IHGB , sob a pena de seu secretário perpétuo, o cônego Januário, decidiu oferecer um prêmio de 200\$000rs para quem apresentasse o melhor "plano de se escrever a história antiga e moderna do Brasil" [...] a comissão julgadora decidiu que a memória apresentada por Karl von Martius (1794-1868) serviria como modelos para futuros trabalhos apresentados ao IHGB» (Valim, 2007, pp. 129-130).
} 
Durante o século XIX, princípios e valores que orientavam as sociedades de Antigo Estado seriam emulados, quase sempre sob a forma de pastiche, pela incipiente burguesia brasileira, latifundiária, rude e escravista Para um país recém-independente, pareceu fundamental forjar uma historiografia de cunho nobilitante e nacionalista, escrita por "homens bons», quase sempre brancos, poderosos e bem-vistos pelos representantes do Império, com que mantinham relações utilitárias, quase nunca pautadas por gestos de discreta nobreza.

A análise dos manuais supracitados indica que, no XIX, seria tarefa inglória localizar livros, sobre a História do Brasil, que apresentassem uma imagem mais isenta de Sebastião José de Carvalho e Melo. Na quase totalidade deles, Pombal não só foi favorecido, mas também caracterizado como estadista que reergueu Lisboa, a partir dos escombros de 1755 , e, tomando a dianteira do rei d. José I, teria reorientado a história do Brasil, meio século antes de proclamada sua (relativa) independência política. 


\section{Bibliografia}

\section{Fontes}

ABREU e LIMA, J. I. de. (1843). Compêndio da história do Brasil (com retratos). Rio de Janeiro: Eduardo e Henrique Laemmert. 2 Tomos.

BRASILIENSE, A. (1876). Lições de história pátria. São Paulo: Typographia da Província.

CORUJA, A. A. P. (1877). Lições da história do Brasil adaptadas à leitura das escolas. Rio de Janeiro: Typographia do Figaro, de Aguiar e Vellozo.

GALANTI, R. M. (1896). Compêndio de história do Brasil, Tomo I. 3ạ ed. São Paulo: Typographia da Industrial.

LACERDA, J. M. de. (1923). Pequena história do Brazil por perguntas e respostas. Rio de Janeiro: Garnier.

MACEDO, J. M. de. (1898). Lições de história do Brasil para uso das escolas de instrucção primária. Rio de Janeiro: H. Garnier.

MAIA, L. de Q. M. (1891). Lições de história do Brasil proferidas no internato do Gymnasio Nacional. 3a ed. Rio de Janeiro: B. L. Garnier.

MARTIUS, K. von. (1956). "Como se deve escrever a História do Brasil». Revista de História de América, No. 42, pp. 433-458.

MENDONÇA, M. C. de. (2005). A Amazônia na Era Pombalina, Tomo III. Brasília: Edições do Senado Federal.

PINHEIRO, J. C. F. (1866). Episódios da história pátria contados à infância. 4ạ ed. Rio de Janeiro: Garnier.

PINHEIRO, J. P. X. (1880). Epitome da história do Brasil desde o seu descobrimento até a conclusão da guerra do Paraguay. 7ạ ed. Rio de Janeiro: Eduardo \& Henrique Laemmert.

ROCHA POMBO, F. (1925) História do Brasil (com muitos mapas históricos e gravuras explicativas). São Paulo: Melhoramentos.

VARNHAGEN, F. A. de. (1877). História Geral do Brasil antes de sua separação e independência de Portugal. Tomo 2ㅇ. 2aㅡ ed. Rio de Janeiro: Laemmert.

VILLA-LOBOS, R. (1896). História do Brasil (Resumo Didático). 4aㅡ ed. Rio de Janeiro: Laemmert. 
Geral

ANDRADE, V. L. C. de Q. (2016). "Colégio Pedro II - patrimônio e lugar de memória da educação brasileira". In: GASPARELLO, Arlette Medeiros; VILLELA, Heloísa de Oliveira Santos (orgs.). Educação na história: intelectuais, saberes e ações instituintes. Rio de Janeiro: Mauad, pp. 101-116.

ARAÚJO, V. L. de. (2008). A experiência do tempo: conceitos e narrativas na formação nacional brasileira (1813-1845). São Paulo: Aderaldo \& Rothschild.

AZEVEDO, J. L. de. (1990). O Marquês de Pombal e a sua época. 2ª ed. Lisboa: Clássica Editora.

BESSA-LUÍS, A. (1990). Sebastião José. Rio de Janeiro: Nova Fronteira.

BRANCO, C. C. (2014). Perfil do Marquês de Pombal. Lisboa: Plátano Editora.

CARVALHO, L. R. de. (1978). As reformas pombalinas da instrução pública. São Paulo: Edusp; Saraiva.

CHAUVIN, J. P. (2016). "Marquês de Pombal: retrato sem moldura». Revista de Estudos de Cultura (Universidade Federal do Sergipe), no. 4, pp. 53-73.

FALCON, F; RODRIGUES, C. (orgs.). (2015). A "Época Pombalina" no mundo lusobrasileiro. Rio de Janeiro: FGV.

FISHER, H. E. S. (1984). De Methuen a Pombal: o comércio anglo-português de 1700 a 1770. Trad. Joaquim Duarte Peixoto. Lisboa: Gradiva.

FRANCO, J. E. et al (orgs.). (2019). Jesuítas e Ilustração: rupturas e continuidades. São Leopoldo: Editora Unisinos.

GUIMARÃES, L. M. P. (2011). Debaixo da imediata proteção imperial: Instituto Histórico e Geográfico Brasileiro (1838 - 1889). 2a ed. São Paulo: Annablume.

HANSEN, J. A. "O Discreto». In: (2019). Agudezas Seiscentistas e Outros Ensaios. São Paulo: Edusp [org. Cilaine Alves Cunha e Mayra Laudanna], pp. 97-122.

MANCHESTER, A. K. (1973). Preeminência inglesa no Brasil. Trad. Janaína Amado. São Paulo: Brasiliense.

MATTOS, S. R. de. (2000). O Brasil em Lições: a história como disciplina escolar em Joaquim Manuel de Macedo. Rio de Janeiro: Access.

MAXWELL, K. (1996). Marquês de Pombal, paradoxo do lluminismo. 2ª ed. Trad. Antônio de Pádua Danesi. Rio de Janeiro: Paz e Terra. 
PINSKY, Jaime. "Nação e ensino de história no Brasil". In: et al. (orgs.). (2017). $O$ ensino de história e a criação do fato. 14a ed, 3a reimp. São Paulo: Contexto, pp. 11-26.

SANTOS, B. B. M. dos. (2011). O currículo da disciplina escolar História no Colégio Pedro II - a década de 1970 - entre a tradição acadêmica e a tradição pedagógica: a história e os estudos sociais. Rio de Janeiro: Mauad; Faperj.

SILVA, R. F. da. (1997). Colônia e nativismo: a história como "biografia da nação". São Paulo: Hucitec.

SODRÉ, N. W. (1969). As razões da Independência. 2a ed. Rio de Janeiro: Civilização Brasileira.

VALIM, P. (2007). Da Sedição de Mulatos à Conjuração Baiana de 1798: a construção de uma memória histórica. Dissertação de Mestrado. Orientação de Carlos Alberto de Moura Ribeiro Zeron. São Paulo: Departamento de História da FFLCH/USP. 


\section{Lei, Argumento e Arte n'O Uraguay}

¿Contra vuestras entrañas tenéis manos, y no contra al tirano en resistillo?

(Alonso de Ercilla)

Porque essas honras vãs, esse ouro puro, Verdadeiro valor não dão à gente (Luís Vaz de Camões)

De la honte à la gloire, et des jeux aux combats. Aux remparts de Paris les deux rois s'avancèrent (Voltaire) $)^{213}$

Resumo: Neste artigo, propõe-se ler o poema $O$ Uraguay, levando em conta pressupostos teológico-políticos e convenções poético-retóricas, sob o influxo da Lei da Boa Razão, promulgada pelo rei d. José I em 1769 - mesmo ano em que a epopeia de Basílio da Gama foi editada em Lisboa. A abordagem relativiza as categorias de autoria e literatura; problematiza os conceitos de verdade e originalidade e discute as concepções de nativismo e nacionalismo no universo setecentista luso-brasileiro.

Palavras-chave: Missões, Lei da Boa Razão, Épica, Basílio da Gama, O Uraguay.

Abstract: In this article, we propose to read $O$ Uraguay, considering theological-political presuppositions and poetic-rhetorical conventions, under the influence of the Law of Good Reason, promulgated by king d. José I in 1769 - in the same year in which the epic poem of Basilio da Gama was published in Lisbon. In This approach we relativize categories like authorship and literature. We also problematize concepts of truth and originality and discuss conceptions of nativism and nationalism in the seventeenth-century Portuguese-Brazilian universe.

Keywords: Jesuit Missions, Law of Good Reason, Epic Poem, Basílio da Gama, O Uraguay.

\section{Proêmio}

Estudiosos das matérias ditas coloniais tendem a estabelecer relações algo mecânicas entre poesia ${ }^{214}$ e verdade ${ }^{215}$, quando se debruçam sobre versos produzidos

\footnotetext{
213 "Da honra à glória, e dos jogos para os combates. Das muralhas de Paris, os dois reis avançam".

214 “[...] se Homero e Hesíodo não conhecem os termos poietés (nome do agente), poíesis (nome da ação) e poíema (nome do resultado da ação), conhecem o verbo poieîn, fazer, cujos significados têm impacto nas noções posteriores do poeta enquanto fazedor ou produtor da poesia como feitura ou produção[,] e do poema como feito ou produto" (BRANDÃO, 2015, p. 22).

215 Joaci Pereira Furtado $(1997$, p. 31) lembra que "Uma interpretação é plausível tanto quanto evite pretensões totalizantes - ou melhor, avizinha-se da totalidade sem[,] contudo[,] esmagar na obra o espaço multifário para outras aproximações. Visto em sua condição peculiar, a partir da perspectiva não menos singular do leitor, o texto necessita ser re-conhecido primeiramente em sua temporalidade, distante do universo onde se concretiza sua leitura extemporânea". Ricardo Martins Valle (2003, p. 106) notou que: "Entre as verdades e deveres que couberam à poesia de Cláudio, as divergências que mais
} 
no mundo luso-brasileiro, entre os séculos XVI e XVIII ${ }^{216}$. Quando o poema traduz afetos e filia-se ao gênero lírico, alguns buscam nele a sinceridade do autor ${ }^{217}$, minorando o fato de que era homem letrado, súdito do reino, validado socialmente e pleno conhecedor das etiquetas e dos preceitos retórico-poéticos, que aplicava em suas composições. Quando a composição encena grandes feitos e pertence ao gênero épico, alguns defendem a autenticidade dos eventos figurados. Num caso, a poesia - que é produto de procedimentos técnicos e pressupõe variadas capacidades de engendrar matérias e articular agudezas - revelaria a personalidade do sujeito que escreve, supostamente imbuído de valores, sentimentos e intenções colhidas em sua biografia. No segundo caso, a matéria poética aportaria credibilidade, na proporção direta com a maior ou menor adesão do poema aos eventos considerados históricos, ou seja, aqueles dignos de serem cantados com a ajuda das Musas, por homens que criam em Deus, senhor deles ou Maria, mãe dos outros.

Leituras desse jaez acontecem quando se ignoram ou desprezam estudos consistentes realizados nos últimos trinta anos, dentro e fora do Brasil, que permitem reconstituir (ainda que parcialmente) as regras e convenções retórico-poéticas empregadas na produção de textos, os modos de circulação oral e/ou impressa e os protocolos de leitura vigentes naqueles tempos ${ }^{218}$ - tão díspares em relação ao impreciso mundinho pós-moderno, que julgamos mais palatável e menos artificial. De acordo com João Adolfo Hansen (2008, p. 18):

Hoje, a presença desse presente extinto só tem existência metafórica em atos contingentes de leitura. Tais atos estão predeterminados pelo intervalo temporal e semântico que separa e diferencia os tempos em que os poemas

ocuparam os discursos de sua recepção recaem quase sempre sobre dois pontos: 1) a situação de Cláudio na história literária, entre 'barroco', 'árcade' e 'pré-romântico' (entendido, este, como uma sorte de proto-historicidade); 2) a situação de Cláudio numa dilemática nacional entre 'patriotismo' e 'lusitanismo'." (grifos do autor).

${ }^{216}$ É o que se verifica, por exemplo, na Apresentação da poesia brasileira, de Manuel Bandeira (2009), e em Uma história da poesia brasileira, de Alexei Bueno (2007), dois manuais bastante populares.

${ }^{217}$ Basílio da Gama teria "[...] simpatia pelo índio, que, abordado quem sabe inicialmente por exigência do assunto, acabou superando no seu espírito ao guerreiro português, que era preciso exaltar, e ao jesuíta, que era preciso desmoralizar. Como filho da 'simples natureza', ele assomou à primeira plana da consciência artística de Basílio" (Candido, 2000, p. 126).

218 Poesia, vale lembrar, é sobretudo artifício. Como afirma Maria do Socorro Fernandes de Carvalho (2007, p. 167), "Postulado de determinada representatividade social, a excelência nas letras é primeiramente perfeição retórica. Sabemos que esse espelho de virtudes funda-se na definição de que todo belo é virtuoso, fonte da prática oratória do elogio [...] Indicativo da prudência de todo autor é conhecer as ocasiões quanto a lugar, matéria, fins, destinatário e artifícios para a construção de agudezas". 
foram inventados, os séculos XVII, XVIII e XIX, do aqui-agora do leitor que os lê produzindo versões necessariamente parciais deles. Obviamente, a epopeia não é pop e o tempo frio da narração dos arcaísmos heroicos alheios às alegorias do marketing entedia mortalmente o leitor já bastante animado pelo tédio do espetáculo global. A extensão e a estranheza do intervalo podem diminuir, no entanto, se a lê como objeto histórico, tentando refazer as operações do pensamento do seu enunciador

Determinados modos de conceber poesias de variados gêneros, espécies, estilos, tópicas, matérias e temas - produzidas nos Estados Brasil e do Grão Pará e Maranhão, até meados do século XVIII ${ }^{219}$-, redundaram em leituras pautadas por impressionismos que sugerem ver determinados textos e textos preambulares ${ }^{220}$ como se se tratasse de peças, se não confessionais, sinceras e autênticas, capazes de desnudar capítulos da história da América Portuguesa e, no plano individual, decifrar lances positivos, obscuros ou controversos na trajetória incerta de homens letrados, fossem eles historiadores, padres ou poetas. Como percebeu Ivan Teixeira (TEIXEIRA, 2003, p. 140), "Dominados pela ideia evolutiva de nação, os primeiros historiadores do Império, identificados com a poética romântica, procuraram no passado uma antecipação que justificasse as conformações do ideário e das práticas sociais do presente, projetando na estrutura pretérita da América Portuguesa pressupostos do próprio tempo".

Incorre-se no risco de forjar conceitos anacrônicos, estabelecer aproximações biográficas pretensamente certeiras e apontar sentimentos de teor nativista ${ }^{221}$, muito antes de Gonçalves de Magalhães proclamar temas e formas nacionalistas, ancorado em Paris - o que só aconteceu meio século depois. Frequentemente, anacronismo, biografismo e nativismo funcionam como tripé que pretende escorar o papel, digamos,

\footnotetext{
${ }^{219}$ O Estado do Maranhão foi criado pelo rei Filipe II em 1621. Em 1654 passou a ser nomeado Estado do do Maranhão e Grão-Pará. Entre 1751 e 1772, foi designado como Estado do Grão-Pará e Maranhão (Cf. MENDONÇA, 1972).

${ }^{220}$ Segundo Anne Cayeula (1996, pp. 15-16): “O livro do Século de Ouro aporta traços concretos de todo procedimento administrativo ao qual deveria ser submetido antes da publicação, sob a forma de preliminares legais, impressos antes do texto: aprovações ou censuras, do Conselho, do Ordinário, da ordem religiosa, aplicáveis ao autor, licença de impressão, privilégio, errata e tasa".

221 "O espírito localista, feição congênita dos mineiros, oriundos das condições físicas e morais do desenvolvimento da capitania, fortificava ali o nativismo ou nacionalismo regional. O sentimento da liberdade e da independência, atribuído geralmente aos montanheses, parece ter em Minas mais uma vez justificado o conceito. Foi este meio que produziu a floração de poetas que é a plêiade mineira" (VERÍSSIMO, 1963, p. 95). Para Vânia Pinheiro Chaves ("A glorificação do Tratado de Madrid, forma original da brasilidade de $O$ Uraguay". In: TEIXEIRA, Ivan. Obras poéticas de Basilio da Gama. São Paulo: Edusp, 1996, p. 458), Basílio expressara, por intermédio do poema, "uma nova forma de pensar, que talvez se possa definir como 'brasileira' pelo seu particular empenho no desenvolvimento da sociedade colonial".
} 
emancipatório das letras, cujos germes da sublevação em favor do Brasil (e, mais tarde, contra o Estado português) e a pretensão de originalidade pessoal se deixariam antever nas entrelinhas da Carta redigida por Pero Vaz de Caminha (1500) ao rei d. Manuel; em História da província de Santa Cruz, de Pero de Magalhães Gândavo (1576); na Notícia do Brasil, publicada por Gabriel Soares de Souza (1587); em História do Brasil, de Frei Vicente Salvador (1627) etc.

Para alguns estudiosos, a busca pela verdadeira intenção dos autores, supostamente detectável em tratados, sermões, cartas e congêneres, permitir-lhes-ia afirmar que, por analogia com a poesia de cunho pessoal, houvesse rastros da sinceridade em obras edificantes, redigidas em versos, a exemplo do relato de pacificação das lutas entre portugueses e emboabas e a fundação da capital das Minas Gerais - matéria do Vila Rica, de Cláudio Manuel da Costa; a descoberta acidental e a conquista industriosa do Recôncavo baiano - descrita por Santa Rita Durão no Caramuru; o relato das chamadas Guerras Guaraníticas em O Uraguay: poema épico que, nos seus 1377 versos, distribuídos em cinco cantos, narra o sangrento conflito de Portugal e Espanha, na rara aliança dos reinos ibéricos em guerra justa contra os ardilosos jesuítas e os índios inocentes, sob seu comando. Publicado em Portugal no ano de 1769, pelo ex-jesuíta e bacharel José Basílio da Gama, a epopeia relacionava o progresso cultural e econômico do reino à conduta do valoroso e sábio Sebastião José de Carvalho e Melo - o superministro do rei d. José I - em renhida disputa com os jesuítas ${ }^{222}$.

Quando se (re)descobre, lê e examina a poesia produzida na segunda metade do Setecentos, nota-se que os manuais de literatura brasileira tendem a apontar nela traços característicos do "movimento árcade", como se se tratasse de sintomas uniformes, comuns e restritos a um punhado de letrados, quase sempre a ocupar ou disputar cargos de relevo na administração reinol. Um dos aspectos mais controversos dessa premissa reside no lugar-comum de que, situado entre o sinuoso Barroco e o Romantismo semregras, o Arcadismo seria uma estética a transitar entre as duas vertentes, renegando uma, inferior, e anunciando outra, rumo ao ápice do Estado-Nação. Nesse sentido, a

222 “O objetivo primeiro da Companhia de Jesus, cuja fundação foi autorizada por Paulo III em 1540, é 'formar bons soldados da Igreja de Roma, capazes de combater na Europa a heresia e os rebeldes e, no resto do mundo, converter os pagãos'." (MAIA, 1986, p. 6). 
poesia pastoril seria capaz de ilustrar - a despeito dos resquícios "culteranos" e "rococós" -, o desejo sincero dos súditos, situados nas partes do Estado do Brasil, de rever o "pátrio rio", descrever as penhas de Minas e, em alguns casos, emancipar-se de Portugal.

Embora as composições poéticas produzidas na capitania de Minas Gerais respeitassem o decoro previsto na construção de caracteres ${ }^{223}$ e adequação da matéria ao gênero e ao estilo correspondente (humilis, mediocris ou gravis) - esquematizados na Roda de Virgílio 224 -, essa informação parece ter sido subestimada pelos primeiros historiadores da "nossa" literatura, no século XIX. Em lugar disso, Januário da Cunha Barbosa, Francisco Adolfo de Varnhagen, Sílvio Romero e João Ribeiro; mais tarde, José Veríssimo, Ronald de Carvalho etc., defendiam que a clareza ${ }^{225}$, a concisão e a elegância da linguagem caracterizariam a Arcadia "brasileira", o que distanciaria "árcades" econômicos de "gongóricos" prolixos e aproximaria "pré-românticos" emancipacionistas de "românticos" patrióticos. Embora os letrados respeitassem a etiqueta cortesã e estivessem habituados a frequentar saraus e sessões em agremiações, onde duelavam verbal e gestualmente, para parte da crítica eles seriam refratários aos jogos de palavra, torneios sintáticos, hipérboles e metáforas agudas exclusividades da estética anterior, a que se etiquetou o nome impreciso de Barroco.

Quando se nega a importância dos códigos de conduta e das preceptivas retórico-poéticas, num universo de raríssimos leitores, desconsidera-se o papel da auctoritas na construção daqueles poemas. Consequentemente, não se distingue autor empírico e persona poética ${ }^{226}$. Determinados poemas traduziriam, quase sem filtros, a

\footnotetext{
223 “Dizemos que os poetas respeitam as conveniências quando as palavras e ações são dignas de cada personagem" (CÍCERO, 1999, p. 49).

224 “[...] a rota Vergilii, do século XIII, (...) elenca tópicas da invenção e palavras da elocução de três estilos, humilde, medíocre e sublime, correspondentes às Bucólicas, às Geórgicas e à Eneida" (HANSEN, 2008, p. 28). De acordo com Alexandre Pinheiro Hasegawa (2011, p. 42), é “[...] [n]a Parisiana poetria (II, 116-121), de João de Garlândia, [...] que descreve a Rota Vergilli, classificação medieval (séc. XII/XIII) que segue a doutrina dos gramáticos latinos".

225 Ivan Teixeira (1999, p. 71) salientava que “[...] a Arte Poética de [Francisco José] Freire integrou o projeto pombalino de desacreditar a neoescolástica jesuítica e apoiar o estilo claro que viria a chamar-se neoclássico".

${ }^{226}$ De acordo com Alcir Pécora (1001, pp. 191-192), em Glaura, de Silva Alvarenga, “[...] parte importante da tradição crítica brasileira tem reconhecido traços realistas do poeta, sobretudo por interesse histórico moderno de estabelecê-los como indícios da superação do seu próprio período nas letras coloniais, isto é, mais precisamente, com o intuito de descobrir nos poemas os signos da formação daquilo que posteriormente se definiria como sistema de uma literatura nacional". Paulo Sérgio de Vasconcellos (2016, pp. 19-20) lembra que "até mesmo filólogos de notável saber e experiência com os textos se
} 
vida feliz, plana ou acidentada do poeta - o que contagiaria seus versos, permitindo radiografar, com suposta precisão, a postura, o papel e a consciência do autor ${ }^{227}$ frente ao Estado Português, um século e meio antes de a psicanálise ser apresentada ao planeta $^{228}$.

Lei

Fumam ainda nas desertas praias Lagos de sangue tépidos e impuros Em que ondeiam cadáveres despidos, Pasto de corvos. Dura inda nos vales $O$ rouco som da irada artilheria.

MUSA, honremos o Herói que o povo rude Subjugou do Uraguai, e no seu sangue Dos decretos reais lavou a afronta. Ai tanto custas, ambição de império! E Vós, por quem o Maranhão pendura Rotas cadeias e grilhões pesados, Herói e irmão de heróis, saudosa e triste Se ao longe a vossa América vos lembra, Protegei os meus versos. Possa entanto Acostumar ao voo as novas asas Em que um dia vos leve. Desta sorte Medrosa deixa o ninho a vez primeira Águia, que depois foge à humilde terra $E$ vai ver de mais perto no ar vazio O espaço azul, onde não chega o raio (GAMA, 2008, p. 257).

deixavam levar por uma concepção biografista do eu expresso na poesia subjetiva da Antiguidade, extraindo do texto poético, imprudentemente, o que seriam informações sobre o autor de carne e osso. Certamente, nesse tipo de consideração da poesia lírica, tão comum até recentemente, pode-se ver a influência das considerações de Hegel sobre a subjetividade da lírica em oposição à objetividade da épica, (...) que associam o eu lírico ao autor empírico". Marcelo Lachat $(2018$, p. 49) observa que: "[...] os manuscritos e impressos seiscentistas e setecentistas (...) não se pautam por critérios autorais vinculados à 'originalidade' (extemporânea a essas práticas letradas). Além disso, muitas vezes, a autoridade poética não decorre somente do nome de um poeta, e sim da própria composição, julgada excelente segundo os ditames do gênero em que está inserida".

227 Conforme salienta João Adolfo Hansen (1992, pp. 35-36), "O nome do autor não é como o nome próprio, que liga o discurso e o indivíduo que o produz. O nome do autor ocorre no limite dos discursos: não está situado no estado civil do produtor, mas na ruptura ou na linha divisória que os discursos instauram entre si, diferencialmente".

228 "Evidentemente, a poesia árcade não estabelece uma simples relação de identidade com o mundo empírico, que seria dado imediatamente como um decalque nas suas formas. É o pressuposto realista de que a poesia é representação da empiria, pelo qual a própria arte do poeta torna-se algo descartável, que determina as críticas brasileiras que propõem o "artificialismo" árcade. É como convenção poética que a representação árcade encontra a realidade de seu tempo, contudo, como sistema de verossimilhanças e decoros partilhado por autores e públicos. Ela põe em representação as interpretações tidas por verdadeiras em seu tempo e também os procedimentos técnicos e, com isso, compõe a compatibilidade entre as interpretações feitas pelos personagens em ato e os atos de interpretação das recepções diferenciadas, que conferem valor e sentido aos poemas" (HANSEN, 1997, pp. 41-42). 
Os versos iniciais de $O$ Uraguay enquadram o cenário sangrento resultante da guerra que portugueses e espanhóis travaram contra milhares de indígenas, que perderam a vida na luta sob o manto, o mando e o comércio dos jesuítas. ${ }^{229}$ Vívida, a cena corresponde à técnica da écfrase - "processo descritivo detalhado por meio do qual se pode produzir 'um quadro' do objeto da descrição" (RODOLPHO, 2012, p. 22). Em meio ao "pasto de corvos", introduz-se, com o apoio da "Musa", a figura do governador e general Andrade 230 - futuro Conde de Bobadela -, "herói" que, ao subjugar o "povo rude", teria lavado "a afronta dos Decretos Reais" 231 . Em seguida, os versos (e as "notas históricas" redigidas por Basílio da Gama) fazem referência ao governador do Estado do Maranhão e Grão Pará, Francisco Xavier de Mendonça Furtado, a quem o poema é dedicado e para quem pede proteção. Para além de julgar as atitudes do homem-poeta e caracterizar os seus versos como sintomas de mera bajulação ${ }^{232}$, com fins pessoais e alcance político ${ }^{233}$, há que se considerar os argumentos que vão neles e os

\footnotetext{
${ }^{229}$ A perfídia dos jesuítas é reforçada no episódio protagonizado pela índia Lindoia, que perde seu companheiro, o líder Cacambo, para as maquinações do Padre Balda, que contraria todas as virtudes esperadas de um religioso: "Obra do seu valor! Tinha Cacambo / Real esposa, a senhoril Lindoia, / De costumes suavíssimos e honestos, / Em verdes anos: com ditosos laços / Amor os tinha unido; mas apenas / Os tinha unido, quando ao som primeiro / Das trombetas Iho arrebatou dos braços / A glória enganadora. Ou foi que Balda, / Engenhoso e sutil, quis desfazer-se / Da presença importuna e perigosa / Do índio generoso; e desde aquela / Saudosa manhã, que a despedida / Presenciou dos dous amantes, nunca / Consentiu que outra vez tornasse aos braços / Da formosa Lindoia e descobria / Sempre novos pretextos da demora" (GAMA, 2008, pp. 281-282). A temática lírica reforça o elemento trágico, presente no poema, o que reforça tratar-se de uma epopeia em que se fundem matérias (a guerra aportada pelos europeus, a morte do casal de amantes, a ambição dos jesuítas) estilos (médio e sublime) e gêneros (épico, trágico, lírico).

230 "O primeiro ministro português Sebastião José de Carvalho e Melo, conde de Oeiras, nomeou como primeiro comissário das demarcações do sul o governador do Rio de Janeiro e Minas Gerais, Gomes Freire de Andrada, cuja dedicação seria compensada com o título de conde de Bobadela. [...] Em setembro de 1751 , os demarcadores europeus zarparam para o Brasil, onde se reuniriam com os oficiais que já estavam na América. Desembarcaram no Rio de Janeiro no dia 27 de outubro" (GOLIN, 2014, pp. 61-62).

${ }^{231}$ O poema dialoga com dois tempos: o de sua enunciação (em 1767, o Diretório dos Índios fora decretado por Francisco Xavier Furtado de Mendonça, no Maranhão; em 1769, fora publicada a Lei da Boa Razão, por d. José I); e o do seu enunciado (em 1750, após dez anos de discussão, havia sido firmado o Tratado de Madri entre Espanha e Portugal; nove anos depois, os jesuítas haviam sido expulsos dos Estados do Brasil, Maranhão e Grão-Pará).

232 "Como representantes de Deus sobre a Terra, os [reis] soberanos exercem seu governo pelo ângulo da justiça, da graça e dos favores. Quando o rei rende justiça, em acordo com cada corpo que sua condição demanda, ele apenas repete o que Deus havia feito quando criou o mundo" (CAMARINHAS, 2012, p. 10). ${ }^{233}$ Lembre-se que a prática acontecia na Itália entre o final da Idade Média e o início do Renascimento: "A entrada dos representantes do estilo do Renascimento em postos na corte, iniciada por Cosimo e já corriqueira sob Lorenzo de Médici, não só ofereceu a esses artistas um círculo mais amplo de influências, mas também deu-Ihes uma autoconsciência que os distanciaria de todas as formas de consciência com que Florença estava familiarizada" (WARNKE, 2001, p. 92).
} 
procedimentos empregados pelo futuro secretário do ministro Sebastião José de Carvalho e Melo, segundo os preceitos do gênero epidíctico, utilizado para elogiar ou censurar. Como defendia Ivan Teixeira:

[...] o específico segmento de discurso em que se encaixa $O$ Uraguay apresenta duas direções aparentemente contraditórias, mas que na verdade são complementares: uma é a propagação do ideário pombalino; outra é a Arte Poética, de Francisco José Freire [...] Em Portugal, o grande modelo desse tipo de composição são os Panegíricos, de João de Barros, cuja leitura ensina que o elogio aos nobres, longe do conceito atual de simples bajulação, tinha a função não só de glorificar o merecimento das ações do elogiado, mas também de instruir os de mais baixa condição pela força do exemplo (TEIXEIRA, 1999, pp. 69-70).

O elogio ao poderoso irmão do ministro comprova essa tese. Nos versos finais, a metáfora pretende aproximar a persona poética de uma jovem águia que, ainda "medrosa", descolará da "humilde terra" e chegará ao firmamento, capaz de para lá levar palavras excelentes, à altura do sublime governador da região Norte do Estado do Brasil, Francisco Xavier de Mendonça Furtado. O cenário, tinto pelo sangue "impuro" dos índios, contrasta com o anúncio do herói (o general Andrade) e o elogio ao irmão de Sebastião José de Carvalho e Melo. Estamos diante de um habilidoso poeta, atento às normas que presidiam a confecção de poemas encomiásticos. O campo de batalha, repleto de corpos inertes, contrasta com a vitalidade e bravura de Andrade. A posição ambígua da persona poética contrasta com a posição superior dos governantes e o lugar altivo que ocupam.

Repare-se que, por se tratar de poema com matéria elevada, Basílio da Gama recorre a certos expedientes que caracterizam o gênero épico. De modo a captar a benevolência dos leitores, o enunciador sugere estar em fase de aprendizagem, "temeroso" como o filhote de uma ave. O procedimento é engenhoso. Ao igualar-se à espécie águia, enaltece a si próprio, tendo em vista que a ave tem virtudes que recomendam a persona poética, a atuar como obediente súdito ${ }^{234}$ do reino, capaz de

\footnotetext{
${ }^{234}$ No canto V, representa-se a sujeição dos sobreviventes ao General Andrade, que ali acumula as funções de guerreiro, pai e emissário do Tratado de Madri: "Entra no povo e ao templo se encaminha / O invicto Andrade; e generoso, entanto, / Reprime a militar licença, e a todos / Co'a grande sombra ampara: alegre e brando / No meio da vitória. Em roda o cercam / (Nem se enganaram) procurando abrigo / Chorosas mães, e filhos inocentes, / E curvos pais e tímidas donzelas. / Sossegado o tumulto e conhecidas / As vis astúcias de Tedeu e Balda, / Cai a infame República por terra. / Aos pés do General as toscas armas / Já
} 
enxergar ao longe e ser preciso em descrever/narrar a história que virá. O poeta fixa o nome dos irmãos (Francisco Xavier e Sebastião José) num poema épico, que ultrapassa as fronteiras do reino. Ao redigi-lo, dialoga com a tradição épica, dos últimos dois séculos, especialmente Alonso de Ercilla (La Araucana, de 1569), Luís Vaz de Camões (Os Lusíadas, de 1572), e Voltaire (La Henriade, de 1723), que servem de epígrafe a este $\operatorname{artigo}^{235}$. Além de considerarmos os artifícios retórico-poéticos aplicados pelo poeta, outra chave de leitura, porventura útil e agradável na aproximação de O Uraguay, residiria na ênfase que a persona poética concede à legislação reinol, mais especificamente a Lei da Boa Razão (TELLES, 1865), promulgada pelo rei d. José I em agosto de 1769. A esse respeito, Íris Kantor (2019, p. 467) observa que a referida Lei:

[...] criava, ainda, uma nova ordem de ambiguidades incompatíveis com os modos de governar típicos da justiça corporativa tradicional. Sob o signo das Luzes, o novo princípio de ordenamento jurídico impôs a revogação dos usos e costumes com menos de cem anos de vigência. Alterava-se radicalmente o sistema jurídico, desautorizando o uso das práticas costumeiras (baseadas no direito romano e na tradição jurisprudencial) em favor de um direito pátrio abstrato.

Aos olhos dos europeus, a guerra era justa (GROTIUS, 2004). Tratava-se de assegurar o cumprimento do Tratado de Madri, firmado pelos reis de Portugal e Espanha, em 1750. Luiz Felipe Baêta Neves (1978, p. 119) lembrava que "As Aldeias são um espaço, território preciso produzido por jesuítas. São, pois, território cristão. 0 Governador-Geral, especialmente no período de Mem de Sá, concede às Aldeias regalias 'quase municipais', comparáveis, em seu estatuto jurídico, às das vilas portuguesas"236. No poema, os europeus são pintados como civilizados, a agir em acordo com outra lógica, a razão de estado. Merece investigação o fato de que, embora a narrativa se

tem deposto o rude Americano, / Que reconhece as ordens e se humilha, / E a imagem do seu rei prostrado adora" (GAMA, 2008, p. 303).

${ }^{235}$ La Ercilla envolve a luta entre espanhóis e índios mapuche, vencida pelo nobre Caupolicán, na Guerra de Arauco. Os Lusíadas retrata a viagem e conquistas de Vasco da Gama, a representar o povo português, em seu caminho para as Índias. Em La Henriade, Voltaire transforma o rei Henri IV em protagonista da narrativa e discute as questões que dividam católicos e protestantes, na França. Todos os poemas tinham dez cantos.

236 "Escolhido o local, o ponto de maior destaque do terreno, com melhor vista da região, era destinado à igreja e quase sempre voltada à sua frente para o norte. [...] A igreja constitui o centro da organização urbanística da povoação, que é planificada, organizada e disciplinada com o rigor de uma produção industrial. Em sua frente era demarcada uma praça retangular, quase quadrada, com lados que variavam entre 100 e 140 metros, e tendo como eixo de simetria a porta principal da igreja" (MALLMANN, 1986, p. 258). 
passe em meados da década de 1750, o poema foi editado no mesmo ano em que o rei d. José I decretou a Lei da Boa Razão. Os dois tempos dialogam, o que talvez explique que, antes dos embates mortais, advenha o duelo de palavras entre portugueses e índios. A persona poética reproduz o discurso pacificador, mas enérgico, pela boca do general Andrade. O diálogo entre ele e os nativos reforça a suspeição do reino em relação à tramoia jesuítica e, simultaneamente, favorece a denúncia sobre a rede de enganos em que os nativos teriam caído. $O$ argumento de $O$ Uraguay funda-se no cumprimento do Tratado de Madri. No plano jurídico, vigente no tempo em que foi escrito, o poema incorpora pressupostos do Diretório dos Índios (1767) e da Lei da Boa Razão (1769). Sobre o Diretório, Rita Helena de Almeida observa que:

[...] veio a lume dois anos depois da Lei de 6 de junho de 1755, que restituiu a liberdade aos índios, e da Lei de 7 de junho, que excluiu os missionários do poder temporal de sua administração. (...) $O$ argumento era o de que, não tendo sido educados com os "meios da civilidade", da "convivência" e da "racionalidade", os índios também estariam inaptos a formar governos próprios, inviabilizando, deste modo, a finalidade da Lei de 6 de junho, quanto ao reconhecimento de sua representatividade política. Entrava-se, assim, no domínio do conceito da menoridade do índio e da necessária tutela (ALMEIDA, 1997, p. 167).

Disputado entre colonos $^{237}$ e jesuítas, desde meados do século XVI, o índio foi embasou argumentos a que os irmãos da Companhia de Jesus recorriam para, supostamente, combater a sua escravização e levar-lhes a palavra santa e consoladora de Deus. Da parte dos colonos, a convivência entre os índios e os religiosos interferia diretamente nos negócios que estes praticavam, com consequências para a coroa portuguesa. Os dispositivos jurídicos lançados por Francisco Xavier de Mendonça Furtado, nos Estados do norte, haviam sido discutidos por cartas, com seu irmão, o ministro Sebastião José de Carvalho e Melo. A aplicação imediata dos decretos implicava criar fendas no Direito Comum. De acordo com António Manuel Hespanha:

A política pombalina do direito - paralela à de outros países europeus na mesma época - visa submeter direito e juristas a um controlo mais estrito da coroa. Esta

237 “Desde o início da colonização do Vale Amazônico, a relação entre colonos e missionários foi violenta. Mathias C. Kiemen reporta que a Companhia de Jesus foi expulsa duas vezes ao longo do século XVII, em 1622 e 1662, pela mesma razão: sua intromissão na relação que os colonos pretendiam estabelecer com os índios. São diversos os autores que afirmam que os missionários detinham um virtual monopólio sobre a distribuição de mão de obra, desde que o Regimento das Missões passou a vigorar, em 1686, e, com isso garantiram para si uma fortuna considerável" (COELHO, 2016, p. 169). 
política desenvolve-se em três frentes de reformas - a da legislação, a do sistema das fontes de direito e a do ensino de direito (HESPANHA, 2006, p. 140). ${ }^{238}$

Em que consistia a Lei da Boa Razão, promulgada no mesmo ano em que $O$ Uraguay foi editado? Tratava-se de centralizar no rei a promulgação das leis, bem como as sanções e vetos e demais dispositivos. Uma das justificativas para o emprego dessa lei residia na tentativa de alinhar o reino de Portugal com as demais nações da Europa. E a Europa, como se sabe, representava o poderio maior do Ocidente. Arno e Maria José Wehling (2004, p. 467) sintetizam as principais mudanças introduzidas com a referida lei:

\begin{abstract}
A lei de 18 de agosto de 1769, dita da Boa Razão, é o instrumento fundamenta desta política contrária ao direito comum. Seus principais dispositivos são francamente centralizadores e uniformizadores: a razão e a vontade do monarca são as fontes do direito; a jurisprudência deveria ser unificada e só seria reconhecida como tal se tornada assento da Casa de Suplicação; o direito consuetudinário só seria admitido se fosse condizente com a boa razão, tivesse mais de cem anos e não se chocasse com a lei; o direito comum só seria admitido quando não conflitasse com a boa razão, entendida esta como as "verdades essenciais, intrínsecas, inalteráveis" evidenciadas no direito divino e natural e nas leis "políticas, econômicas, mercantis e marítimas" das "nações civilizadas".
\end{abstract}

\title{
Argumento \& Arte
}

Ao analisar a disposição das partes que compõem o poema, Ivan Teixeira aponta que "[...] preâmbulo não-narrativo (vv. 1 - 20) e situação inicial da narrativa (vv. 21 244)" seriam as duas seções do Canto I. Deste modo, o proêmio ocuparia os versos de 1 a 5; a invocação/proposição e verso de transição, os versos de 6 a 9; já a dedicatória estaria situada entre o décimo e o vigésimo versos. Deste modo, "a segunda parte do canto preocupa-se exclusivamente com os antecedentes da ação do poema" (TEIXEIRA, 1996, pp. 99-100) Durante o “congresso de heróis", que se preparavam para a batalha contra os índios, ouve-se este diálogo entre o espanhol Catâneo e o governador português:

\footnotetext{
238 “Em meados do século XVIII ocorre um processo generalizado na Europa contra aspectos considerados arcaicos da sociedade ou do Estado, que envolve não apenas os intelectuais iluministas [...], mas a própria burocracia estatal em vários países. O direito comum, jus commune, que era o direito civil fortemente enraizado na tradição romanista, a multiplicidade de tribunais e instâncias judiciais e o prestígio dos doutrinadores na elaboração das sentenças eram todos fatores considerados negativos para o estabelecimento de uma justiça eficaz e efetivamente centralizada" (WEHLING; WEHLING, 2004, p. 466).
} 
Levantadas as mesas, entretinham

O congresso de heróis discursos vários.

Ali Catâneo ao General pedia

Que do princípio lhe dissesse as causas

Da nova guerra e do fatal tumulto.

Se aos Padres seguem os rebeldes povos?

Quem os governa em paz e na peleja?

Que do premeditado oculto Império

Vagamente na Europa se falava

Nos seus lugares cada qual imóvel

Pende da sua boca: atende em roda

Tudo em silêncio, e dá princípio Andrade:

O nosso último rei e o rei de Espanha

Determinaram, por cortar de um golpe,

Como sabeis, neste ângulo da terra,

As desordens de povos confinantes,

Que mais certos sinais nos dividissem

Tirando a linha de onde a estéril costa,

E o cerro de Castilhos o mar lava

Ao monte mais vizinho, e que as vertentes

Os termos do domínio assinalassem.

Vossa fica a Colônia, e ficam nossos

Sete povos, que os Bárbaros habitam

Naquela oriental vasta campina

Que o fértil Uraguai discorre e banha.

(GAMA, 2008, pp. 261-262)

O protagonismo dos portugueses, em relação aos espanhóis, é reforçado por uma série de procedimentos, na disposição mesma do poema, em que o banquete remete à tradição épica cultivada desde a Antiguidade. É o General Gomes Freire de Andrade quem mais faz uso da palavra, ao longo dos cantos. Detentor de um éthos pragmático e racional, o herói é configurado como personificação de virtudes guerreiras, combinadas à capacidade de argumentar (logos), em defesa do jugo imposto pelos reinos da Ibéria, que supostamente agiam estritamente para que se cumprisse o acordo firmado entre os reis. Isso não o impedia de se sentir incomodado em guerrear contra os índios - sentimento que acentuaria a sua boa índole, combinada ao fato de representar a civilidade de um legítimo súdito do reino, capaz de perceber e exercer compaixão (pathos).

A narrativa sugere que o maior obstáculo não eram os índios, mas os padres jesuítas, que se recusavam a ceder as reduções indígenas aos europeus. Em sua composição, Basílio da Gama enalteceu a empatia dos portugueses em relação aos índios, sem perder de vista a ambiguidade embutida nessa aproximação, pois 
precisavam combatê-los. No plano poético, essa dupla orientação reflete-se na oscilação de cenas amenas e trágicas, a alternar paz e guerra, vida e morte etc. Para além dos episódios inventados pelo poeta, recorde-se que a arte de escrever combinava-se à competência de atestar credibilidade e obedecer aos códigos que vigoravam na corte, desde meados do século XVII, como destaca Marco Antonio Silveira (1997, p. 49):

[...] a partir da metade do Seiscentos, um novo quadro se delineou no Império português - para além das alterações de caráter político-administrativo, acentuou-se e difundiu-se o uso de formas de fidalguia com o intuito de se aproximar da "civilização". Estabeleceu-se em Portugal, na verdade, um arranjo particular do "processo civilizatório". Ser civilizado dependia do título adquirido ou do papel desempenhado na estrutura burocrático-patrimonialista; porém, significava, acima de tudo, ser um "bom vassalo" e um "bom cristão".

No Uraguay, embora os índios sejam coadjuvantes na narrativa, revelam-se adversários valentes que, além disso, refutam coerentemente o discurso dos invasores europeus $^{239}$. Ao pintar os nativos desse modo, poder-se-ia afirmar que Basílio da Gama recorreu a um procedimento que seria aplicado no Caramuru, doze anos depois: o de sobrevalorizar o papel dos portugueses, justamente por enfrentarem oponentes tão hábeis em lutar, quanto em contra-argumentar ${ }^{240}$ :
Notava o General o sítio forte,
Quando Meneses, que vizinho estava, Lhe diz: Nestes desertos encontramos Mais do que se esperava, e me parece Que só por força de armas poderemos Inteiramente sujeitar os povos.
Torna-lhe o General: Tentem-se os meios De brandura e de amor; se isto não basta, Farei a meu pesar o último esforço. Mandou, dizendo assim, que os índios todos Que tinha prisioneiros no seu campo Fossem vestidos das formosas cores, Que a inculta gente simples tanto adora.

\footnotetext{
239 “Esta população relativamente grande de índios era governada [...] por um número insignificante de sacerdotes que, sem dispor de nenhuma força europeia e sempre em maus termos com os colonos espanhóis por sua firme postura contra a escravidão dos índios, não possuíam meios de coerção. Por isso, os índios deveriam estar em conformidade com seu governo, pois se não fosse assim, os jesuítas não teriam poder para impedir que regressassem a sua vida selvagem" (GRAHAM, 2000, p. 201).

240 Para Luciana Gama (2003, p. 130): “A construção da representação do indígena no Caramuru passa pela aspereza cuja finalidade, sem dúvida, é tornar as ações do herói Diogo Álvares mais grandiosas, que, por sua vez, representa, como sabemos, a tópica do esforço jesuítico/católico no descobrimento, que, por sua vez, é argumento fundamental inserido nas práticas letradas em favor da volta da Companhia de Jesus no Setecentos português".
} 


\author{
Abraçou-os a todos, como filhos, \\ $E$ deu a todos liberdade. Alegres \\ Vão buscar os parentes e os amigos, \\ $\mathrm{E}$ a uns e a outros contam a grandeza \\ Do excelso coração e peito nobre \\ Do General famoso, invicto Andrade. \\ Já para o nosso campo vêm descendo, \\ Por mandado dos seus, dous dos mais nobres. \\ Sem arcos, sem aljavas; mas as testas \\ De várias e altas penas coroadas, \\ E cercadas de penas as cinturas, \\ E os pés, e os braços e o pescoço. \\ Entrara Sem mostras nem sinal de cortesia \\ Sepé no pavilhão. Porém Cacambo \\ Fez, ao seu modo, cortesia estranha, \\ E começou: Ó General famoso, \\ Tu tens à vista quanta gente bebe \\ Do soberbo Uraguai a esquerda margem. \\ Bem que os nossos avôs fossem despojo \\ Da perfídia de Europa, e daqui mesmo \\ Co's não vingados ossos dos parentes \\ Se vejam branquejar ao longe os vales, \\ Eu, desarmado e só, buscar-te venho. \\ Tanto espero de ti. E enquanto as armas \\ Dão lugar à razão, senhor, vejamos \\ Se se pode salvar a vida e o sangue \\ De tantos desgraçados [...] \\ (GAMA, 2008, pp. 265-266).
}

Os argumentos apresentados pelos corajosos índios desarmados não convencem o general português, o que faz deste um dos episódios-chave de O Uraguay. Sem chegarem a um acordo pacífico, o diálogo sugere que a má influência dos jesuítas é que impelia os nativos a resistir à demarcação de terras por espanhóis e portugueses. De todo modo, não se pode ignorar que Cacambo se refere aos seus ancestrais, traídos pelos europeus. O embaixador indígena reconhece a miséria em que eles se encontravam, mas não a associa ao fato de estarem sob o comando dos jesuítas. Essa aparente contradição reforça a tópica de que o índio seria inocente, como diziam os vários tratados, diálogos e relações sobre as partes do Brasil, redigidos desde o século XVI. Seria possível questionar a habilidade discursiva dos líderes indígenas? Ivan Teixeira demonstrou que não:

Poder-se-ia, à primeira vista, objetar uma tal proficiência retórica num índio americano, como se objetou durante muito tempo a opulência verbal de o rei de 
Melinde em sua conversa com Vasco da Gama, no final do canto II de Os Lusíadas. [...] No caso de Cacambo, não procede, porque o seu desempenho verbal, além de agenciar informações importantes à trama do poema, funciona como índice de assimilação da civilização europeia, para a qual foi convertido e da qual não poderá jamais tirar nenhum proveito em favor de seu povo, ainda que demonstre eficiência na manipulação daquele código (TEIXEIRA, 1996, p. 51).

Como a oferta de paz não é aceita pelo general português, a narrativa oferece um segundo ponto para exame. À primeira vista, poder-se-ia atribuir aos europeus a responsabilidade pela violenta guerra - anunciada no tenso diálogo entre Andrade e Cacambo. Porém, vale recordar que portugueses e espanhóis estavam imbuídos do senso de dever. Súditos da coroa, não haveria como irem de encontro ao desejo dos reis, expresso no Tratado. Em meio aos primeiros lances da guerra, Sepé aparece em sonho ao amigo Cacambo e sugere que ateie fogo ao acampamento dos rivais, para lavar a afronta de sangue.

Foge, foge, Cacambo. E tu descansas, Tendo tão perto os inimigos? Torna, Torna aos teus bosques, e nas pátrias grutas Tua fraqueza e desventura encobre. Ou, se acaso inda vivem no teu peito Os desejos de glória, ao duro passo Resiste valeroso; ah tu, que podes! $E$ tu, que podes, põe a mão nos peitos À fortuna de Europa: agora é tempo, Que descuidados da outra parte dormem. Envolve em fogo e fumo o campo, e paguem $\mathrm{O}$ teu sangue e o meu sangue. Assim dizendo Se perdeu entre as nuvens, sacudindo Sobre as tendas, no ar, fumante tocha; E assinala com chamas o caminho.

Acorda o índio valeroso, e salta Longe da curva rede, e sem demora $\mathrm{O}$ arco e as setas arrebata, e fere $O$ chão com o pé: quer sobre o largo rio Ir peito a peito a contrastar co'a morte. Tem diante dos olhos a figura Do caro amigo, e inda lhe escuta as vozes. Pendura a um verde tronco as várias penas, E o arco, e as setas, e a sonora aljava; $E$ onde mais manso e mais quieto o rio Se estende e espraia sobre a ruiva areia Pensativo e turbado entra; [...] E o índio afortunado a praia oposta Tocou sem ser sentido. Aqui se aparta 
Da margem guarnecida e mansamente

Pelo silêncio vai da noite escura

Buscando a parte donde vinha o vento.

Lá, como é uso do país, roçando

Dous lenhos entre si, desperta a chama,

Que já se ateia nas ligeiras palhas,

E velozmente se propaga [...]

(GAMA, 2008, pp. 279-280).

O episódio parece acumular duas funções: ressaltar a atitude torpe dos índios e enaltecer a retidão dos portugueses, que não haviam lançado mão de expedientes dessa natureza, apesar de reivindicarem o direito às missões, conforme estipulava o Tratado de Madri. Consequentemente, na trama poética o argumento em defesa da guerra justa ganha mais força. Como recomendavam as retóricas antigas, especialmente de Cícero, o episódio pretende "mover as paixões" do leitor, com vistas a justificar o comportamento dos portugueses, como se se tratasse de uma reação à iniciativa questionável dos nativos.

\section{Pátria?}

Como se disse, nem sempre a leitura de O Uraguay ultrapassou o discurso nacionalista, atribuído ao poema a partir do século XIX. Em capítulo redigido na virada para o século XX, José Veríssimo (1996, p. 421) supunha que "faltava ao poeta o recuo necessário no tempo para uma idealização verdadeiramente poética do acontecimento, cujos atores ainda viviam". Talvez a ressalva do crítico procedesse. Mas parece difícil decifrar o que Veríssimo entendia por uma "idealização verdadeiramente poética". Essa concepção descolada dos eventos relacionados à violenta guerra entre europeus e índios talvez explicasse algum equívoco na afirmação anacrônica de que haveria "Romantismo no poema de Basílio da Gama" (VERÍSSIMO, 1996, p. 423). Teria o célebre historiador utilizado "Romantismo" em lugar de "lirismo"? As impressões de José Veríssimo parecem ter contagiado parte significativa da crítica posterior, como foi o caso de Povina Cavalcanti, que, em 1928, supôs que "O Uraguay" teria sido "a nossa primeira oficina de modas: o primeiro ateliê do bom gosto literário indígena" (CAVALCANTI, 1996, p. 429). Quatro anos depois, o português Manuel da Silva Gaio (1932, p. XIV) afirmava o seguinte a respeito da poesia bucólica, em seu país: 
Seja qual for o género cultivado por um novelista ou poeta, há de a sua obra impor-se, não porque obedeça a fixados preceitos, estabelecidos para esse determinado género, mas só pelo que intrinsecamente represente e signifique: - como revelação sincera da maneira de ser do autor;

- como expressão bela de sentimentos profundos, dominadoras paixões, ideias soberanas;

- como reflexo vivo do meio natural e social sob cuja influência ele a concebeu e realizou, obedecendo ou reagindo a quaisquer normas.

Manuel Bandeira (2009, p. 34) também reagiu negativamente ao poema de Basílio da Gama, em 1946. Talvez reverberando a leitura de Sílvio Romero e José Veríssimo, para ele "Não há grandeza de inspiração no Uraguai: os seus méritos residem na beleza das paisagens, correção e brilho da forma, fino sentimento no episódio da morte de Lindoia." Em 1961, o professor catedrático do Colégio Pedro II, Clóvis Monteiro, sugeria que:

[...] a literatura brasileira já nasceu clássica e erudita no século XVII, quando se achava em pleno triunfo o Culteranismo na Europa. Foi culteranista, como a portuguesa, até os meados do século XVIII; daí por diante, até o advento da Escola Romântica, desenvolveu-se em consonância com o Arcadismo, que animado em Portugal, como na Itália, de espírito reacionário, tendente a prestigiar os verdadeiros princípios da escola Clássica (MONTEIRO, 1961, pp. 115-116).

Em 1970, Alfredo Bosi (2001, p. 65) retomou a hipótese de Antonio Candido, anunciada na Formação da Literatura Brasileira, em 1959, segundo qual O Uraguay seria um poema "que melhor se diria lírico-narrativo do que épico", pois não seguiria rigorosamente os preceitos do gênero ${ }^{241}$. Dentre as leituras subsequentes, chama atenção o ensaio de Vânia Pinheiro Chaves, redigido em 1994. A pesquisadora começara por salientar a resposta dada pelo jesuíta Lourenço Kaulen ao poema de Basílio, em 1786: "A virulência com que Kaulen contra-ataca e argumenta a favor da sua Ordem leva-o não só a negar todo e qualquer valor à obra, mas ainda a imputar aos nosso poeta graves defeitos de caráter" (CHAVES, 1996, p. 425). Outra virtude do artigo de Chaves estava em salientar o fundamento político-teológico para as ações adotadas pelo general português: “o herói do poema [...] frisa bem o caráter político-econômico-social da falta cometida pelos padres, quando apresenta aos embaixadores índios as razões de

\footnotetext{
${ }^{241}$ Hipótese contestada por Ivan Teixeira, em Mecenato Pombalino e Poesia Neoclássica (1999), para quem o poema se inspirava em épicos da Antiguidade; em Os Lusíadas, de Camões; e em La Henriade, de Voltaire.
} 
sua ação, e que, para o poeta, o seu principal pecado consiste na criação de uma 'República Infame', ou melhor, de um 'império tirânico, que usurpam' aos soberanos ibéricos" (CHAVES, 1996, p. 454). No ano seguinte, o mexicano Jorge Antonio Rueda de la Serna (1995, p. XVIII) lamentava:

[...] o crescente desinteresse sobre o tema entre os estudiosos da literatura e o preconceito generalizado contra a poesia arcádica. Essa ideia comum, acerca de sua artificialidade e bajulação, explica, em grande parte, a escassa disposição para entregar-se à árdua tarefa de voltar aos velhos materiais - o que exige um paciente labor muitas vezes de decifração crítica.

Rejeitar a etiqueta patriótica afixada a $O$ Uraguay, bem como a suposta sinceridade (ou falta dela), por parte do poeta Basílio da Gama (que não se confunde necessariamente com a persona poética), não impede vislumbrar as qualidades estéticas do poema. Pelo contrário, talvez haja maior interesse em salientar os elementos que permitem considerá-lo uma epopeia breve, em que o general Andrada figura como herói, pintado como pacífico, mas enérgico. Representante do poder real, ele é capaz de se compadecer com o destino infeliz dos índios, embora cumpra com vigor as leis ordenadas pelos reis de Portugal e Espanha. Outro expediente que permitiria classificar O Uraguay como poema épico está no diálogo dos europeus entre si (enquanto se posicionavam nas imediações do território a ser disputado aos índios sob o comando da Companhia de Jesus), e nos confrontos verbais entre portugueses e nativos, a explicitar argumentos de um e de outro lado, antes que se concretizasse a sangrenta batalha com uso das armas.

Por esse motivo, na discussão sobre as matérias e gêneros, porventura seria mais produtivo caracterizar a sina de Lindoia não como episódio romântico, mas como excurso amoroso, em acordo com os preceitos do gênero lírico. Longe de ser um apêndice narrativo, trata-se de cena relevante, que também serve a reforçar o argumento que embala o poema, desde os versos iniciais: além de acentuar o caráter da índia e o sofrimento de seu irmão Caitutu, o sacrifício de Lindoia realça o contraste entre a ética dos nativos e a má-fé atribuída aos jesuítas, condensada na figura torpe do Padre Balda, que enviara Cacambo para a morte com a intenção de casar Lindoia (recém viúva) com o seu filho Baldeta, a fim de torná-lo cacique da tribo. A esse respeito, devese recordar a tradição, na poesia épica, que desde Homero reservava espaço para 
eventos capitaneados por Eros (ou Cupido, entre os latinos), paralelamente à narrativa dos grandes feitos. Aceita esta observação, seria possível afirmar que o poema atende às recomendações de Voltaire, no prefácio a La Henriade. 


\section{Referências}

ALMEIDA, Rita Heloísa de. O Diretório dos Índios: um projeto de "civilização" no Brasil do século XVIII. Brasília: Editora UnB, 1997.

BANDEIRA, Manuel. Apresentação da poesia brasileira seguida de uma antologia. São Paulo: Cosac Naify, 2009.

BOSI, Alfredo. História concisa da literatura brasileira. 39ạ ed. São Paulo: Cultrix, 2001.

BRANDÃO, Jacyntho Lins. Antiga Musa: arqueologia da ficção. 2a ed. Belo Horizonte: Relicário, 2015.

BUENO, Alexei. Uma História da Poesia Brasileira. Rio de Janeiro: Ermakoff, 2007.

CAMARINHAS, Nuno. Les magistrats et l'administration de la justice. Le Portugal et son empire colonial (XVII-XVIII siècle). Paris: L'Harmattan, 2012.

CANDIDO, Antonio. "O disfarce épico de Basílio da Gama". In: Formação da Literatura Brasileira (momentos decisivos). 1ㅇv volume (1750-1836). 9a ed. Belo Horizonte: Itatiaia, pp. 121-129.

CARVALHO, Maria do Socorro Fernandes de. Poesia de Agudeza em Portugal: estudo retórico da poesia lírica e satírica escrita em Portugal no século XVII. São Paulo: Humanitas; Edusp, 2007.

CAVALCANTI, Povina. "Relendo o Caramuru e O Uraguay". In: TEIXEIRA, Ivan. Obras poéticas de Basílio da Gama. In: TEIXEIRA, Ivan. Obras poéticas de Basílio da Gama. São Paulo: Edusp, 1996, pp. 427-433.

CAYEULA, Anne. Le paratexte au siècle d'or. Genebra: Droz, 1996.

CHAVES, Vânia Pinheiro. "A glorificação do Tratado de Madrid, forma original da brasilidade de O Uraguay". In: TEIXEIRA, Ivan. Obras poéticas de Basilio da Gama. São Paulo: Edusp, 1996, pp. 451-468.

CÍCERO. Dos Deveres. Trad. Angélica Chiappetta. São Paulo: Martins Fontes, 1999.

COELHO, Mauro Cezar. Do sertão para o mar. Um estudo sobre a experiência portuguesa na América: o caso do Diretório dos Índios (1770-1798). São Paulo: Editora Livraria da Física, 2016.

FURTADO, Joaci Pereira. Uma República de leitores: história e memória na recepção das Cartas Chilenas [1845-1989]. São Paulo: Hucitec, 1997.

GAIO, Manuel da Silva. Bucolismo I - Bernardim Ribeiro. Coimbra: Imprensa da Universidade de Coimbra, 1932. 
GAMA, Basílio da. O Uraguay. In: TEIXEIRA, Ivan (org.). Épicos. São Paulo: Edusp/Imprensa Oficial, 2008, pp. 251-314.

GAMA, Luciana. "A retórica do sublime no Caramuru: poema épico do descobrimento da Bahia. Revista USP, São Paulo, n. 57, pp. 122-137, 2003.

GOLIN, Tau. A guerra guaranítica: o levante indígena que desafiou Portugal e Espanha. São Paulo: Terceiro Nome, 2014.

GRAHAM, Robert B. Cunninghame. La Arcadia perdida. Una historia de las missiones jesuíticas. Trad. Alicia Jurado. Buenos Aires: Emecé, 2000.

GROTIUS, Hugo. O Direito da guerra e da paz. 2 vol. Trad. Ciro Fioranza. Florianópolis: Ed. Unijuí, 2004.

HANSEN, João Adolfo. "Autor". In: JOBIM, José Luis (org.). Palavras da crítica: tendências e conceitos no estudo da literatura. Rio de Janeiro: Imago, 1992, pp. 11-43.

HANSEN, João Adolfo. "As liras de Gonzaga: entre retórica e valor de troca". Revista Via Atlântica, São Paulo, n. 1, pp. 41-42, 1997.

HANSEN, João Adolfo. "Notas sobre o gênero épico". In: TEIXEIRA, Ivan (org.). Épicos. São Paulo: Edusp/Imprensa Oficial, 2008, pp. 17-91.

HASEGAWA, Alexandre Pinheiro. Os Limites do Gênero Bucólico em Vergílio: um estudo das éclogas dramáticas. São Paulo: Humanitas, 2011.

HESPANHA, António Manuel. O Direito dos Letrados no Império português. Florianópolis: Fundação Boiteaux, 2006.

KANTOR, Íris. "Novas expressões da soberania portuguesa na América do Sul: impasses e repercussões do reformismo pombalino na segunda metade do século XVIII". In: FRAGOSO, João; GOUVÊA, Maria de Fátima. O Brasil Colonial, vol. 3 (ca. 1720 - ca. 1821). 3ạ ed. Rio de Janeiro: Civilização Brasileira, 2019, pp. 463-482.

LACHAT, Marcelo. "Saudades de Lídia e Armido", poema atribuído a Bernardo Vieira Ravasco: estudo e edição. São Paulo: Alameda, 2018.

MAIA, Pedro. Ratio Studiorum: método pedagógico dos jesuítas. São Paulo: Edições Loyola, 1986.

MALLMANN, Alfeu Nilson. Retrato sem retoque das missões guaranis. Porto Alegre: Martins Livreiro, 1986.

MENDONÇA, Manuel Carneiro de. Raízes da Formação Administrativa do Brasil, Tomo I. Rio de Janeiro: IHGB, 1972. 
MONTEIRO, Clóvis. Esboços de História Literária. Rio de Janeiro: Oficinas Gráficas do Colégio Pedro II, 1961.

NEVES, Luiz Felipe Baêta. O combate dos Soldados de Cristo na Terra dos Papagaios: colonialismo e repressão cultural. Rio de Janeiro: Forense Universitária, 1978.

LA SERNA, Jorge Antonio Ruedas de. Arcádia: tradição e mudança. São Paulo: Edusp, 1995.

PÉCORA, Alcir. Máquina de Gêneros. São Paulo: Edusp, 2001.

RODOLPHO, Melina. Écfrase e evidência nas letras latinas: doutrina e práxis. São Paulo: Humanitas, 2012.

SILVEIRA, Marco Antonio. O universo do indistinto: estado e sociedade nas Minas setecentistas (1735-1808). São Paulo: Hucitec, 1997.

TEIXEIRA, Ivan. "História e ideologia em O Uraguay". In: . Obras poéticas de Basílio da Gama. São Paulo: Edusp, 1996, pp. 45-98.

TEIXEIRA, Ivan. Mecenato Pombalino e poesia neoclássica. São Paulo: Edusp, 1999.

TEIXEIRA, Ivan. "Hermenêutica, retórica e poética nas letras da América Portuguesa". Revista USP, São Paulo, n. 57, pp. 138-159, 2003.

TELLES, José Homem Corrêa. Comentários à "Lei da Boa Razão". Lisboa: Tipografia de Maria da Madre de Deus, 1865.

VALLE, Ricardo Martin. "A construção da posteridade ou A gênese como ruína: um ensaio sobre Cláudio Manuel da Costa". Revista USP, São Paulo, n. 57, pp. 104-121, 2003.

VASCONCELLOS, Paulo Sérgio de. Persona Poética e autor empírico na poesia amorosa romana. São Paulo: Editora Unifesp, 2016.

VERÍSSIMO, José. História da Literatura Brasileira: de Bento Teixeira (1601) a Machado de Assis (1908). 4ạ ed. Brasília: Editora UnB, 1963.

VERÍSSIMO, José. "O Uraguay, de Basílio da Gama". In: TEIXEIRA, Ivan. Obras poéticas de Basílio da Gama. São Paulo: Edusp, 1996, pp. 421-426.

WARNKE, Martin. O artista da Corte: os antecedentes dos artistas modernos. Trad. Maria Clara Cescato. São Paulo: Edusp, 2001.

WEHLING, Arno; WEHLING, Maria José. Direito e Justiça no Brasil Colonial: o Tribunal da Relação do Rio de Janeiro [1751-1808]. Rio de Janeiro: Renovar, 2004. 


\section{Revisão do Caramuru}

[...] existem dois tipos de injustiça: um, da parte daqueles que mal fazem, o outro, da parte daqueles que, quando podem, não protegem do erro aqueles a quem o mal é infligido (Marco Túlio Cícero). ${ }^{242}$

[...] vós sois convidados a reconhecer a Santa Igreja como senhora e dominadora do mundo inteiro e a prestar vossa homenagem ao Rei espanhol, como a Senhor vosso (Juan López de Palacios Rubios)..243

[...] todas as ações que se executam ou contra a consciência ou contra a lei, são em si más

(Tomás Antônio Gonzaga). ${ }^{244}$

Resumo: Caramuru: Poema Épico do Descobrimento da Bahia (1781) é uma dessas obras que, ombreada com outras do mesmo período e lugar, foi lida até recentemente como composição de qualidade inferior, cujo interesse seria mais histórico que poético; e o valor, mais documental que artístico. Malgrado o lugar secundário a que lhe rebaixou a crítica brasileira, o poema do Frei José de Santa Rita Durão (1722-1784) passou a ser lido com perspectiva menos anacrônica e mais justa desde meados do século XX. A década de 2000 representou ganho em qualidade e rigor dos estudos em torno da epopeia. Neste artigo, propõe-se a revisitar a fortuna crítica e apresentar nova leitura sobre o poema.

Palavras-Chave: Santa Rita Durão; Caramuru; Épica; Século XVIII.

Abstract: Caramuru: Poema Épico do Descobrimento da Bahia (1781), it's a work that, combined with another poems from the same period and place, until recently was read as a composition of inferior quality, whose interest would be more historical than poetic; and, concerning his value, it would be more documentary than artistic. Despite the secondary place to which Brazilian criticism put this poem, Frei José de Santa Rita Durão (1722-1784) was read without an anachronistic view and a fairer perspective, since the middle of the 20th century. The 2000s represented a gain in quality and rigor in the studies around the epic. In this article, we propose to revisit the critical fortune and present a new reading on the poem.

Keywords: Santa Rita Durão; Caramuru; Epic; 18th Century.

\section{Inventio}

Supondo-se que o leitor não esteja bem familiarizado com a epopeia Caramuru, convém dizer do que se trata. Publicado em Lisboa no ano de 1781, o poema relata o

\footnotetext{
242 Dos Deveres (CÍCERO, 2017, p. 22).

243 Requerimiento lido aos índios pelos espanhóis em 1513 (RUIZ, 2002, p. 77).

${ }^{244}$ Tratado de Direito Natural (GONZAGA, 2004, p. 67).
} 
naufrágio de uma embarcação portuguesa, próxima do Recôncavo baiano, no início do século XVI. ${ }^{245}$ Sete sobreviventes ${ }^{246}$ chegam à terra e logo são submetidos aos cuidados dos nativos, que se alimentarão de suas carnes à medida que se recompuserem. Diogo Álvares Correia escapa ao ritual antropofágico, por fazer uso da pólvora para abater uma ave. Percebido como um ser mágico, ademais com poder de fazer fogo, ele passa a liderar os índios da região e se une monogamicamente - como recomendavam os costumes da igreja católica - a Paraguaçu, filha do cacique tupinambá. Após enfrentar tribos inimigas, parte com ela em direção à Europa, onde serão abençoados por Catarina de Médici, que rebatiza a índia com o próprio nome (Catarina Álvares). No regresso ao Estado do Brasil, Paraguaçu tem uma visão dos dias que virão, em meio às lutas e conquistas do Reino. Diogo Álvares Correia retoma a liderança dos tupinambás e, recompensado pela Coroa, amplia seu poderio e alcance.

Coma epopeia de Santa Rita Durão foi recebida? Em 1826, Ferdinand Denis afirmou que "não falta[va]m méritos ao poema Caramuru" (DENIS Apud CÉSAR, 1978, p. 47). No mesmo ano, Almeida Garrett sugeriu que, nele, “O estilo é[era] ainda por vezes afetado; lá surdem aqui e ali seus gongorismos; mas onde o poeta se contentou com a natureza e com a simples expressão da verdade, há oitavas belíssimas, ainda sublimes" (GARRETT Apud CÉSAR, 1978, p. 91 - grifo do autor). Em 1850, Francisco Adolfo de Varnhagen (1946, p.35) acreditava que "Este poema, mais acabado que o anterior [ $O$

\footnotetext{
245 "Ao desembarcar na Bahia, em 1510, muito provavelmente em consequência de um acidente de navegação, o português de nome Diogo Álvares se viu cercado de índios, cujas disposições eram hostis, nem mais ou menos. Para espantá-los, Diogo Álvares teve a feliz ideia de descarregar seu bacamarte. A detonação semeou o espanto entre os índios, e fazendo-os passar, sem demora, da animosidade ao respeito, valeu a Álvares, da parte deles, o famoso apelido de Caramuru, nome de um peixe, do gênero da enguia, cujas descargas elétricas provocam uma violenta comoção" (LIMA, 2000, p. 36).

${ }^{246}$ Agradeço a Maria Fernandes de Carvalho e Leonardo Zuccaro, pelos relevantes apontamentos feitos a este artigo, em sua versão inicial. Devo a Cleber Vinícius do Amaral Felipe (2020, p. 10) a oportuna lembrança de um episódio da Odisseia, no canto IX, transcorrido na ilha em que reside Polifemo. Ao recriar o naufrágio de Diogo Álvares Correia e seus companheiros, Durão reverberaria Homero? É possível: "Numa passagem do canto IX da Odisseia, Polifemo aprisionou Odisseu e seus companheiros, devorando seis deles durante o dejejum. Antropofagia e falta de hospitalidade são duas práticas notadamente censuráveis aos olhos do protagonista, pois os homens jamais deveriam consumir alimentos crus, negligenciar as hecatombes, ignorar os rituais de purificação ou deixar de acolher os estrangeiros, práticas condizentes com o ambiente da pólis. Polifemo, ao contrário, zombava de "Zeus hospitaleiro", conduta que causou sua ruína: depois de deixá-lo ébrio, Odisseu perfurou seu único olho e fugiu às pressas na companhia dos sobreviventes. Em momento algum Homero alegou tratar-se de uma ilha, mas o poeta Eurípedes, no século $V$ a. C., relendo o episódio em chave satírica, associou a terra dos ciclopes à ilha da Sicília, informação que foi repetida na Eneida, de Virgílio. Logo, a ilha em questão reúne no seu âmago personagens míticas que atuam como antípodas do homem excelente detentor da virtude (areté) e merecedor de fama perene (kléos)".
} 
Uraguai], é de fácil e natural metrificação, e dicção clara e elegante; nele o poeta só pelo seu gênio conseguiu fazer herói um indivíduo, que estava longe de o poder ser". Treze anos depois, Ferdinand Wolf supôs que aquele "[...] assunto, em verdade, não se presta(va) ao épico[,] senão no sentido mais amplo do vocabulário: conviria melhor a uma sequência de cantos semelhantes aos romances espanhóis, ou antes: a um romance (...) Ademais, Durão não enriqueceu a tradição com qualquer achado particular, e também não a modificou de modo original" (WOLF Apud CÉSAR, 1978, pp. 158-159). Na virada do século XIX para o XX, Sílvio Romero (1902, p. 108) supôs que:

Não foi inutilmente que apareceram Matos, Durão, Basílio, Gonçalves Dias, A. de Azevedo, Martins Pena, Agrário de Meneses, Alencar, Macedo, Varela, Tobias Barreto, Manuel de Almeida e Celso de Magalhães. Estes nomes pertencem à história; não é possível passar sobre eles uma esponja para satisfazer caprichos. É uma questão diversa, que pertence à crítica e não à história, saber se essa literatura é pobre ou opulenta, original ou não. Julgo-a pobre; mas é sempre uma literatura.

Um pouco depois dele - em relativa (e rara) convergência de gosto e opinião -, José Veríssimo (1963, p. 115) defendeu que:

Pela sua concepção e execução era o Caramuru, mais do que o Uraguai, um dos muitos poemas saídos da fonte camoniana. Sem embargo desta falta de originalidade inicial, da mesma forma e estilo poético, e de reminiscências do poema de Camões, tem o Caramuru qualidades próprias estimáveis.

Afora menções ligeiras em outros manuais, tão concisos quanto superficiais ${ }^{247}$, Antonio Candido (2000) e Sérgio Buarque de Holanda (1991) ${ }^{248}$ talvez tenham sido os

\footnotetext{
247 "Pela originalidade do estro e do feitio, assim como pela força da expressão, o Uraguai, de Basílio da Gama, é o mais perfeito e melhor poema aparecido no Brasil, em todo o período colonial; Santa Rita Durão ainda era um camoniano, e Cláudio um discípulo fidelíssimo da escola arcádica francesa e italiana, como os demais poetas do seu grupo" (CARVALHO, 1968, p. 151). "Durão ficou em nossa literatura como autor da epopeia Caramuru (1781). O poema é mais nosso do que o Uraguai, pelo assunto e pela intenção patriótica; mais extenso (dez cantos). Não tem, no entanto, a originalidade do outro. Durão apegou-se em tudo ao modelo camoniano (BANDEIRA, 2009, p. 35). "Dividido em dez cantos em oitavas camonianas, ou seja, na exata divisão formal de Os Lusíadas, [Caramuru] narra o descobrimento da Bahia por Diogo Álvares Correia. Publicado onze anos depois de O Uraguai, parece arcaico em relação a este, embora talvez caldeie mais elementos especificamente brasileiros do que o último" (BUENO, 2007, p. 49).

248 "As tentativas épicas foram a debilidade e o anacronismo mais flagrante do século XVIII, não obstante tão aferrado ao senso das proporções e culto das formas naturais. Fraqueza a que não escapou o próprio Voltaire (muito ao contrário!) e alastrou o século de uma produção abundante e medíocre" (CANDIDO,
} 
primeiros a reorientar a percepção do poema, sem, contudo, retirá-lo do limbo anacrônico, plagiário e nacionalista em que ele fora metido pela crítica do Oitocentos. Dentre outros fatores que levaram em conta, a discussão girava em torno do gênero (épico): Caramuru continuou sendo avaliado, positiva ou negativamente, em contraste com poetas antigos e autores de seu tempo. A esse respeito, Ivan Teixeira (2003, p. 156) sugeria ser:

[...] pouco estimulante a tentativa de retomada da velha discussão sobre a suposta inadequação de $O$ Uraguai a um conceito abstrato e universal de epopeia, pois é inevitável que os gêneros literários também se transformaram. Assim como o epos de Camões não é o mesmo de Virgílio e o deste não se confunde com o de Homero, o de Basílio da Gama diferencia-se de seus antecessores por se inscrever no discurso doutrinário da ilustração portuguesa, cuja poética foi sistematizada por Freire (1759, vol. II, Livro III, p. 165), que o define da seguinte maneira: "A epopeia é a imitação de uma ação heroica, perfeita e de justa grandeza, feita em verso heroico por modo misto, de maneira que cause uma singular admiração e prazer e, ao mesmo tempo, excite os ânimos a amar as virtudes e as grandes empresas".

De maneira geral, a epopeia ${ }^{249}$ de Durão - similarmente ao modo como incerta crítica $^{250}$ procedeu em relação à Prosopopeia, de Bento Teixeira - foi classificada como obra sem maior qualidade, e afixada como marco temporal de um momento histórico em que se prenunciavam os ventos da pretensa "originalidade", emancipação política e ausência de regras que se atribuem ao Romantismo brasileiro, a embalar, desde o Setecentos, uma espécie de protonacionalismo (embora o poema tenha sido

2000, p. 169). "Não parece exato dizer-se que, em tudo isso, ele [Durão] fuja à convenção épica. O certo é que, ao compor seu poema, deve ter tido presente, constantemente, a tradição mais venerável do gênero e que através e além do modelo camoniano, procura beber nas mesmas fontes de que bebeu Camões. Seu Diogo Álvares é, na verdade, um herói civilizador típico: não o fora também, e de modo eminente, o herói do poema que, desde o Renascimento, servira de paradigma a todas as mais famosas epopeias? Eneias, o pio Eneias, tem sua réplica americana, digna de ocupar a 'douta lira' e o zelo religioso e apostólico de Durão" (HOLANDA, 1991, p. 96).

249 "A fábula épica é feito ilustre; grande ação de herói, rei ou chefe, que ensina uma verdade moral com o exemplo espantoso. Narrada como ficção semelhante à história, exige a ordem artificial (ordo artificialis), o uso de caracteres, pensamentos e costumes heroicos com palavras de estilo alto ou sublime. Segundo os preceptistas, deve ser grande, maravilhosa, inteira, uma e verossímil” (HANSEN, 2008, p. 48). ${ }^{250} \mathrm{Na}$ tentativa de menosprezar os estudos retórico-poéticos, que levam em conta as especificidades de produção e circulação de textos do século XVI, XVIII e XVIII, parte dessa crítica procede pela tentativa de exclusão, como adverte Caio César Esteves de Souza (2017, p. 16): “[...] o silêncio construtivo trabalha ativamente para garantir que um conjunto de sentidos não passe do campo do não-dito ao do dito, para que um enunciado possa continuar sendo enunciado sem que perca o seu sentido unívoco, sua hegemonia". 
concebido, escrito e publicado em Lisboa - capital do Reino, para onde José de Santa Rita Durão seguira em 1731 e de onde nunca mais retornou ao Estado do Brasil). Seria mais produtivo não afiliar o Caramuru a um gênero pré e pós-datado, no século XVIII, e considerarmos o tempo e o lugar onde foi composto, bem como o repertório cultural de Durão e os artifícios retórico-poéticos que empregou, sem perder de vista a perspectiva teológico-política que embasava a epopeia que transformou Diogo Álvares Correia em protagonista virtuoso da conquista do Recôncavo baiano e, por extensão, da capitania da Bahia. Haveria igual interesse em notar que o português foi caracterizado como líder enérgico, porque armado de coragem, audácia e pólvora; mas também ordeiro e pacifista, porque teria (com)vencido o gentio pela palavra, como anuncia a décima quarta estrofe do segundo Canto:

Mas Diogo, naqueles intervalos, Suspendendo o furor do duro Marte, Esperança concebe de amansá-los, Uma vez com temor, outra com arte: A viseira levanta e vai buscá-los, Mostrando-se risonho em toda parte; Levantai-vos (Ihes diz) e assim dizendo, la-os co'a própria mão da terra erguendo (DURÃO, 2005, p. 51).

Destro nas armas e nas palavras, Diogo Correia é ambicioso. Eleita Paraguaçu como esposa, o casal vai à Europa, onde reafirma fidelidade ao Rei, que lhe autoriza e incentiva a desbravar maior território na capitania, ocupado por gentes não "civilizadas" e "violentas", desviadas do caminho verdadeiro e famintas de carne humana. Nuno Camarinhas (2012, p. 10) lembra que:

Representantes de Deus na Terra, os soberanos exerciam seu governo pela ótica da justiça, da graça e dos favores. Quando o rei faz justiça para cada corpo, em acordo com a sua demanda, ele só repete o que Deus havia feito quando criou o mundo. À imagem de Deus, senhor da Justiça, mas também do Amor, o rei é capaz de moderar suas decisões por meio da graça.

Espanta que as leituras menos anacrônicas sobre o poema Caramuru sejam bem recentes, no Brasil. Em 2000, Ronald Polito preparou uma edição bem cuidada do 
poema, que chama atenção. Lançada pela editora Martins Fontes (coleção Poetas do Brasil), a publicação deve ser saudada como iniciativa relevante, tanto do ponto de vista artístico quanto crítico, já que o pesquisador dava os primeiros sinais de que a crítica canônica poderia ser revisitada e aprimorada, em pontos gerais e específicos. A seu ver:

[É] Notável que esses e outros críticos do século passado [XIX] relevem os traços que se tornarão tópicos de crítica ao Caramuru nas épocas posteriores, ou para conferir-Ihe qualidades positivas ou defeitos. De qualquer modo, eles não esgotam as leituras que já foram propostas e, por outro lado, respondem, grosso modo, a expectativas próprias do universo romântico da literatura brasileira do século XIX, com seu desejo e busca do exótico, do genuinamente brasileiro, do rol milionário de nossas riquezas naturais e culturais, em que desponta a figura do índio, finalmente entronizada (POLITO, 2005, pp. XXIX e $X X X)$.

Três anos depois, Luciana Gama escreveu um ensaio em que revelou como Frei de Santa Rita Durão incorporara os preceitos de Longino, em Do Sublime ${ }^{251}$. Em 2008, foi a vez de Berty Biron reinterpretar o poema, à luz da razão de Estado ${ }^{252}$ vigente em Portugal, ao final do Setecentos. No ano seguinte, Ricardo Martins Valle (2009) estudou extensa jurisdição relativa às guerras, ditas "justas", promovidas pelos europeus. Mais recentemente, pesquisas de Rodrigo Gomes de Oliveira Pinto (2015), Caio César Esteves de Souza (2017), Leonardo Zuccaro (2019) e Heidi Strecker Gomes (2020), reforçam a hipótese de que a poesia luso-brasileira, produzida entre os séculos XVI e XVIII, precisaria ser lida em acordo não com o projeto nacionalista do século XIX, nem

\footnotetext{
251 “A primeira fonte do sublime é a mais considerável, cuja definição está por todo o Tratado [de Longino]. Trata- se do que podemos considerar como o caráter do orador, que em linhas gerais não deve ter espírito humilde e desprezível, já que "não é possível que aqueles que são acostumados a pensar baixa e servilmente e que nisto trabalham toda a vida, hajam de produzir coisa admirável e digna de toda a posteridade" (GAMA, 2003, p. 125).

252 “De modo geral, o pressuposto doutrinário das versões católicas e luteranas da 'razão de Estado' é a unidade de integração das partes do 'corpo' à 'cabeça', discutida por Santo Tomás de Aquino no Comentário do livro V da Metafísica de Aristóteles. Neste, uma rede cerrada de metáforas organicistas figura a sociedade política como um corpo humano definido escolasticamente, no qual o tronco e os membros se submetem à cabeça. (...) A metafísica do 'corpo' é substancializada nos textos neoescolásticos dos séculos XVI e XVII; no caso de Portugal, é apropriada na doutrina do 'pacto de sujeição' do 'corpo místico do Estado' feita por Francisco Suárez em De Legibus, tornando-se um dos fundamentos do direito absoluto e do direito ordinário também no Estado do Brasil, onde regula o exclusivo monopolista e a ação jesuítica" (HANSEN, 2019, pp. 78-79).
} 
com o ponto de vista do leitor fincado na perspectiva multimídia e hiperindividualista ${ }^{253}$ do século XX e XXI. Como alertava Ivan Teixeira (2003, p. 140):

A segunda parte da expressão "literatura colonial brasileira" também merece comentário. Dominados pela ideia evolutiva de nação, os primeiros historiadores do Império, identificados com a poética romântica, procuraram no passado uma antecipação que justificasse as conformações do ideário e das práticas sociais do presente, projetando na estrutura pretérita da América Portuguesa pressupostos do próprio tempo, com seu modo específico de compreender e organizar a realidade social, assim como de conceber a estruturação e a função da obra de arte.

Desde os estudos pioneiros no Brasil, realizados por João Adolfo Hansen, Alcir Pécora, Adma Muhana, Ivan Teixeira, Marcello Moreira, Joaci Pereira Furtado, Roberto Acízelo de Souza, Marco Antonio Silveira, Íris Kantor, dentre outros, não há muito cabimento em atribuir sentimento nacionalista, sinceridade e consciência nativistaemancipatória ${ }^{254}$ a um súdito português, quase sempre comprometido com as questões da Igreja e do Reino ${ }^{255}$. Também não há sentido em supor espontaneidade e originalidade ${ }^{256}$ artística em um teólogo, homem letrado e duplamente submetido ao corpo místico - conceito colocado em prática pela Coroa desde o final da Idade Média. Desse modo, não havia exatamente vaidade autoral em Frei José de Santa Rita Durão; tampouco, sanha editorial ou ambição comercial, sendo ele um poeta que referendava a guerra justa ${ }^{257}$ contra os índios da capitania da Bahia, em nome da fé que pretendia

\footnotetext{
253 Em analogia com o conceito de "Hipermoderno", discutido por Gilles Lipovetsky (2004).

254 "O sentimento nativista amadurece no decorrer do século XVII, gerando conflitos sangrentos entre os filhos da terra e os portugueses, provocando nas atividades literárias o interesse pela natureza e pela história do Brasil, afirmando-se nos gabos muitas vezes excessivos" (BANDEIRA, 2009, p. 15). Alfredo Bosi (2012, p. 225 e ss.) vê traços "nativistas" na cultura "brasileira" do "final do século XVIII", antes de proclamada a Independência política e territorial do território, sob forte pressão inglesa, em 1822.

255 Dizia Tomás de Aquino (2009, p. 185): “Como toda a Igreja é denominada um único corpo místico por comparações ao corpo natural do homem, que segundo os diversos membros, exerce diversos atos, como ensina o Apóstolo na Carta aos Coríntios, assim Cristo é denominado cabeça da Igreja por comparação com a cabeça humana. Nesta, podemos considerar três aspectos: ordem, perfeição e poder".

256 "[...] a noção de autor como presença é imediatamente anacrônica quando o efeito da sua representação unitária é assumido e generalizado, estendendo-se a discursos que não o enunciam, como na repetição ritual das 'sociedades de discurso' de rapsodos da Grécia arcaica, nas sociedades précolombianas, em sociedades xamanistas e em outras, que não pressupõem o indivíduo, a consciência e o progresso, como a antiga Roma e as inúmeras tradições latinas produzidas pelas apropriações dos discursos antigos. É apenas no século XVIII que surge o autor-presença e a generalização atual da autoria, como identidade ideal e/ou causalidade psicologista, é invariavelmente a de esquemas projetivos muito próximos aos da exegese cristã que alegava a santidade do Autor quando pretendia provar o valor de um texto" (HANSEN, 1992, p. 14).

${ }^{257}$ Em 1625, Hugo Grotius (1901, s/p) defendia "haver um comando especial para executar o julgamento de Deus perante nações culpadas pelos piores crimes". Cf. Instituição da Coisa Bélica (VALLE, 2009).
} 
anular diferenças, do arcabuz que imobilizava, e da razão de estado que desconsiderava vontades pessoais, afora a do rei - soberano, por definição e estatuto ${ }^{258}$. Como mostrou Norbert Elias (2001, pp. 125-126):

Aquilo que é "racional" depende sempre da estrutura da sociedade. O que denominamos objetivamente "razão", ou ratio, vem à tona sempre que a adaptação a uma determinada sociedade e a sobrevivência dentro dela demandam uma precaução ou cálculo específicos e, com isso, uma retração de emoções individuais efêmeras.

A posição do Frei era, no mínimo, ambígua. Como religioso que frequenta os restritos círculos do Paço, ele materializava o princípio teológico-político subjacente à leitura do poema que compôs, em acordo com preceitos retórico-poéticos. Tratava-se de uma sociedade altamente cifrada, em que corte, fidalguia e clero se comportavam entre o dogma, a lei e o extenso poder Real. Como ensinou Magalhães Godinho (1971, p. 68), "O clero constitui o primeiro braço do Reino (...) Por um lado, forma uma organização própria, com a sua hierarquia interna, para mais dependente de uma cabeça que se situa no estrangeiro". Na outra ponta daquelas sociedades, o índio chamado de "gente bestial" e inocente, por Pero Vaz de Caminha (CORTESÃO, 1994, p. 166) -, cuja língua não admitiria as noções de moral ("nem Fé"), justiça ("nem Lei") ou poder soberano ("nem Rei"), segundo Pero de Magalhães de Gândavo (2004, pp. 135136) - repetido, em 1627, por Frei Vicente do Salvador (1965, p. 85) - e que supostamente não precisava trabalhar para melhor viver, como esses e outros cronistas decretaram, voltou a ser descrito e noticiado como "indolente" e prejudicial ao latifúndio por sujeitos da nova velha ditadura brasileira.

Poderíamos afirmar que Caramuru era e permanece "atual"? Não exatamente, pois não se trata de denunciar os maus tratos impingidos ao gentio do século XVI, mas

\footnotetext{
258 "É nesta corte, de brilho breve, que desponta a etiqueta. Nasce de um ritual preciso: o da adoração do príncipe. O duque de Borgonha compõe, a partir do luxo, de uma largueza sem par no Ocidente, e das maneiras refinadas, uma estratégia voltada para a exaltação de sua pessoa e o seu reconhecimento como soberano. Já o primeiro duque adota em seus atos a fórmula 'tal é o nosso prazer', característica dos reis absolutos, porque significa que a vontade do legislador é causa suficiente para a eficácia da lei. O 'belprazer' do príncipe vem da expressão latina quod principi placuit habet vigorem legem, 'o que apraz ao príncipe tem força de lei', ressuscitada pelos juristas da escolha de Bolonha a partir do século XI" (RIBEIRO, 1990, pp. 28-29).
} 
de enaltecer as virtudes do povo português. Heroicizado ${ }^{259}$, em acordo com o gênero (épico), a matéria (industriosa) e o estilo (gravis) ${ }^{260}$, Diogo está para os conquistadores, assim como a capitania da Bahia, para o Estado do Brasil. É discutível atribuir índole benevolente a Santa Rita Durão, por ser Frei; ou mapear sinais "indianistas" no poema, por retratar índios; ou, ainda, supor que o poeta se preocupasse com a veracidade dos fatos, por transliterar anedotas e lendas que entraram para manuais de história, contemporâneos ao poema. Magalhães Godinho (1971, p. 90) chamava atenção para o caráter ambivalente da sociedade do Antigo Estado português: “[...] a longo prazo, a sociedade assume por isso esse caráter ambíguo que the empresta uma ordem nobiliárquico-eclesiástica assente numa economia mercantilista até à medula".

\section{Dispositio}

Rigoroso na emulação de modelos letrados e na aplicação de técnicas retóricopoéticas que reafirmavam dogmas metafísicos e leis do Reino, os dez cantos do Caramuru recordavam a hierarquização social e tentavam persuadir o leitor, fosse ele vulgar ou discreto. ${ }^{261} \mathrm{Em}$ contato com o poema, situado mais de dois séculos antes de nosso tempo, seria desejável subtrair da análise a visão romantizada de autoria e individuação ${ }^{262}$ do escritor; e não ajuizar o poema improcedentemente, como se se

\footnotetext{
${ }^{259}$ De acordo com João Adolfo Hansen (2008, p. 34) “As definições luso-brasileiras de epopeia dos séculos XVI, XVII e XVIII incluem-se na longa duração dos preceitos aristotélicos do gênero, mas expurgam o maravilhoso antigo. Quando não o moralizam alegoricamente, substituem-no pelo maravilhoso cristão ou indígena".

${ }^{260}$ Na síntese de Rodrigo Gomes de Oliveira Pinto (2015, p. 27): “[...] desde a Rhetorica ad Herennium (ca. séc. I a.C.), são três os genera aos quais os discursos se reduzem: 'et grave et mediocre et attenuatum', a saber, grave, medíocre e atenuado (Rhet. Her. IV 11, 16). No jargão latino empregado por Cícero após as lições do anônimo, aponta Marcos Martinho dos Santos lendo o De oratore, o Orator, o Brutus e o De optimo genere oratorum, dos três gêneros, um é 'grave ou pleno ou sublime ou amplo ou grandíloquo ou veemente ou copioso', outro é 'sutil ou tênue ou atenuado ou compresso ou remisso ou humilde', outro, enfim, é 'médio ou medíocre ou temperado ou módico ou intermediário'."

261 "Na cultura ibérica do século XVII, o tipo do discreto é modelado, assim, pela retórica aristotélica apropriada na doutrina escolástica de uma história providencialista, segundo a qual os casos vividos por homens ilustres do passado são exemplos para a experiência política do presente. É discreto, por isso, aquele que pauta as ações pela sollertia, a sagacidade escolástica. Divivida em perspicácia e versatilidade, a sollertia permite achar instantaneamente, nos exemplos passados memorizados como eruditio ou erudição, a imagem adequada à ocasião" (HANSEN, 2019b, p. 104).

262 "A regra nuclear da auctoritas antiga é o costume (consuetudo) que prescreve o decoro interno do discurso como adequação das partes do todo e, deste, aos preceitos da auctoritas já realizada pelos clássicos; ao mesmo tempo, prescreve o decoro externo, como adequação verossímil à recepção. $\mathrm{A}$
} 
tratasse de cópia artificial, datada e ineficaz de versos tidos por melhores. Não nos esqueçamos de que, na enunciação dos quase sete mil versos, a persona poética criada por Durão rimava catequese e expansão territorial, equilibrando os dogmas da Igreja Católica e as ordenações do Reino.

Por esses e outros motivos, seria mais profícuo recorrer às preceptivas que circulavam na Europa e territórios, frequentavam ordens religiosas e orientavam glosas e disputas ${ }^{263}$ poéticas em academias. Os poetas aplicaram ou adaptaram certos preceitos, na emulação de regras de composição, decoro e modelos letrados, não reduz o escopo de leitura, nem reduz o potencial de análise e interpretação de um poema como Caramuru. Pelo contrário, permite nos situarmos mais perto das condições de produção letrada, além de aproximá-lo de textos produzidos em seu tempo, conforme sugeriu Stephen Greenblatt, ao descrever o que entendia por "poética cultural". 264

Quem conhece minimamente os manuais de retórica de Aristóteles, Cícero ou Quintiliano; os tratados de poética de Horácio ou Longino; as obras que ensinavam modos de falar e regras de cortesia, como Castiglione, Gracián etc., percebe que não se trata de meros catálogos com listas de tropos e figuras, mas que as técnicas de persuasão, as variantes de dissimulação e as maneiras de produzir afetos - previstos e ilustrados neles - combinavam-se de múltiplos modos: tão ou mais variados que as possibilidades sugeridas pelos tratados de versificação do século $\mathrm{XX}^{265}$ (e nos quais dificilmente um crítico de nossos dias põe reparo). Nem sempre esses pressupostos são considerados, na abordagem dos poemas, embora concebidos segundo a forma mentis de tempos muito distantes do nosso. Renato Janine Ribeiro (1990, p. 9) nota que: “Desde o século XIX, a concepção da história como ciência tendeu a desqualificar as antigas explicações oferecidas para os acontecimentos políticos e sociais: procuram-se causas mais profundas para uma guerra do que ambições dinásticas ou a glória ofendida de um rei".

auctoritas relaciona-se intimamente coma urbanitas, um uso culto e civil da língua" (HANSEN, 1992, p. 25).

263 Lectio e disputatio integravam o método de ensino jesuítico. O primeiro consistia na exposição de um tema previamente preparado pelo aluno. O segundo envolvia debates entre estudantes, sobre um mesmo tema, com vistas a exercitar a eloquência perante o professor e os demais estudantes (Cf. MAIA, 1986; CAMBI, 1999; CAMARINHAS, 2012).

${ }^{264}$ Ivan Teixeira (1999; 2003) talvez tenha sido o maior interlocutor de Greenblatt, no Brasil.

265 Por exemplo, Versificação Portuguesa, de Said Ali (edição de 2006) e "A Versificação em Língua Portuguesa", de Manuel Bandeira (edição de 1997). 
Exposta a matéria, tratemos de suas partes. O primeiro canto do Caramuru relata o naufrágio do barco onde estavam Diogo Álvares Correia e os demais tripulantes, dentre eles, Fernando, que conta a história protagonizado por Auréu, em meio aos tupinambás. Os versos finais (desse canto) descrevem a preparação do ritual antropofágico. O segundo canto contém o episódio relacionado ao tiro que muda a sorte do português. Gupeva, falante habilidoso, descreve o que entende por inferno no canto III. Nos versos finais, aproximam-se os caetés. A batalha toma o canto seguinte, com cenas de violência vívidas, como recomenda a técnica da écfrase ${ }^{266}$.

No Caramuru temos na maioria dos cantos o procedimento da descrição amparada nas ações dos indígenas em campo de batalha e não uma descrição mais claramente moral que visa a mostrar as características espirituais e do caráter indígena. Procedimento este que nos sugere que a intencionalidade aqui é argumentar em favor da capacidade de organização e, portanto, política, da sociedade indígena, baseada no modo como esses utilizavam seus instrumentos (GAMA, 2003, p. 132).

No canto $V$, enquanto os prisioneiros da guerra são preparados como cardápio, o índio Embiara é morto. Há um novo ataque dos inimigos. Neste canto, o líder branco mata o índio da tribo rival Jararaca com um tiro de espingarda. Também morre Bambu, fato a que a persona poética confere menor importância, pois pretende realçar as artimanhas e habilidades do herói. Berty Biron (2008, p. 344) bem o percebeu:

É digno de nota que o poeta Santa Rita Durão observa o ideal horaciano, segundo o qual a poesia deve ser utilis e dulcis, coerentemente com o conceito de sua dupla função: utilidade e deleite. Nesse sentido, revela-se a função educativa, em que o poeta exalta as virtudes do herói como ideais de moral e ética: a prudência norteia o herói cristão, que se subordina à Metrópole para

\footnotetext{
${ }^{266}$ Leonardo Zuccaro (2019, pp. 24-25) explica que: “Enargôs é um advérbio de modo derivado do adjetivo enargés, da qual também deriva o substantivo enárgeia, figura (skhêma) que muito aparece em textos tanto gregos como latinos, e é justamente o meio pelo qual a ékphrasis produz o efeito de conduzir aos olhos o objeto exposto. Vertida por Quintiliano por euidentia, ou seja, "vividez" ou "evidência", não está, contudo, associada somente à ékphrasis, ao menos não na Antiguidade clássica e tardia, ocorrendo para qualificar discursos em geral, como por exemplo em Dionísio de Halicarnasso, para quem ela é característica da elocutio do orador Lísias (Lys., 7)26; ou em Ps.- Élio Aristides, em que o vocábulo aparece diversas vezes para qualificar o bom discurso político (ou deliberativo) (Cf. Ael. Ar., Ars II.80; II.110; II.122), e no próprio Quintiliano (Inst. Orat., 4.2.63)".
} 
empreender a "guerra justa" contra os inimigos da Igreja e do rei de Portugal. Além disso, o poema deixa entrever o verdadeiro trabalho de educação dos indígenas realizado pelos jesuítas.

O sexto canto narra a partida de Diogo e Paraguaçu para a França e o afogamento de Moema, que, apaixonada pelo português, pulara atrás do batel. Por sinal, a ênfase no pathos, a comoção do leitor pretendida pelo poeta nesta cena, levou parte considerável da crítica a esquecer os recursos eficazes empregados no episódio. Os artíficios continuam. No canto seguinte, descreve-se a pomposa chegada do casal à França. Ao rei, descrevem-se animais considerados monstruosos. Nos cantos VIII e IX, Paraguaçu (batizada Catarina) comunica visões sobre o destino de Portugal, entre o século XVI (combates entre Tamoios e os franceses liderados por Villegaignon) e o XVII (guerras dos portugueses contra os holandeses). Paralelamente às leituras que percebem a articulação entre retórica/poética e teologia/política no poema de Santa Rita Durão, há que se enfatizar que ele foi concebido segundo a forma mentis de uma sociedade de Antigo Estado, submetida ao racionalismo cortesão, segundo Norbert Elias (2001, p. 110):

A "racionalidade da corte", se podemos chamar assim, não recebe o seu caráter específico, como a racionalidade científica, nem em função do esforço pelo conhecimento e controle de fenômenos naturais exteriores ao humano, nem em função do planejamento calculado da estratégia na concorrência pelo poder econômico, como a racionalidade burguesa. (...) seu caráter específico deriva, em primeiro lugar, do planejamento calculado da estratégia de comportamento em relação a possíveis perdas e ganhos de status e prestígio sob a pressão de uma competição contínua pelo poder.

Quer dizer, a publicização do poema facultava e favorecia a distinção social de um homem letrado que, alinhado com as premissas e motivações do governo de Dona Maria, justifica teológica e politicamente a atuação dos "conquistadores" portugueses, em sua busca por "salvar" as almas dos índios ${ }^{267}$ que habitavam a capitania da Bahia. Na síntese de Marco Antonio Silveira,

[...] torna-se explícito o modelo de vassalo que se adaptava ao arranjo particular do "processo civilizatório" no Império português. O desejo

\footnotetext{
267 “Ao mencionar São Gregório Nazianzeno, Durão tem em vista destacar a importância, no contexto de sua obra, do ministério da Trindade, que o teólogo celebra em seus discursos, em oposição ao monoteísmo judaico e ao divino difuso do paganismo. E, em seguida, menciona São Paulino, monge beneditino a quem o Papa Gregório Magno envia à Inglaterra, onde o missionário converte o rei Edwin à fé católica" (BIRON, 2008, pp. 329-330).
} 
incansável de servir a Sua Majestade, carregado de fidelidade e amor à ordem, acompanhava o respeito a Deus e seus religiosos, a caridade, o "juízo delicado" e até mesmo certo apego aos livros e "artes liberais" (SILVEIRA, 1997, pp. 5354).

Determinados episódios pareciam reforçar o caráter bravio e guerreiro, mas pacífico e prudente ${ }^{268}$, dos valorosos portugueses ${ }^{269}$. Como afirma João Adolfo Hansen (2008, p. 169): "Seu éthos ou caráter é, como diz Luzán catolicamente, ser valente com prudência, constante com magnanimidade, obediente aos preceitos dos deuses, observante das cerimônias de sua religião, afável e benigno" ${ }^{270}$. Diogo sobreviveu ao afogamento, caçou, liderou os nativos e combateu os inimigos do Vaticano, e da Coroa, com diligência. Faz jus à alcunha Caramuru, que o distingue perante os índios, em reconhecimento de sua força e nomeia uma epopeia que protagoniza.

\section{Elocutio}

A tradição greco-latina cristalizou a divisão da arte retórica em partes ${ }^{271}$, dentre elas a Elocução (Lexis > Elocutio), que consistia no modo como o orador se dirigia ao ouvinte ou ao leitor com clareza e elegância, para persuadi-lo(s), comovê-lo e agradálo. No terceiro livro da Retórica, Aristóteles (2012, p. 191) advertia que: "A expressão possuirá a forma conveniente se exprimir emoções e caracteres, e se conservar a 'analogia' com os assuntos estabelecidos. Há analogia se não se falar grosseiramente acerca de assuntos importantes, nem solenemente de assuntos de pouca monta, nem se colocarem ornamentos numa palavra vulgar". Em meados do XVIII, o então célebre

\footnotetext{
268 "Segundo o Filósofo [Aristóteles], a prudência é a 'reta razão aplicada ao agir, ou seja, é algo próprio da razão prática" (AGOSTINHO, 2005, p. 5). "A substância não basta; também se requer a circunstância" (GRACIÁN, 2011, p. 348).

269 O que reforça a hipótese de Marcos Antonio Silveira (1997), apoiado em Johann Huizinga (em Outono da Idade Média), de que nas sociedades de Antigo Estado a violência dos nobres convivia com estritas regras de cortesia.

${ }^{270}$ Rodrigo Gomes de Oliveira Pinto (2-15, pp. 23-24) ilustra-o com numerosos exemplos colhidos na tradição: Nos termos da lição que Torquato Tasso apresenta em seu Discorsi dell'arte poetica ed in particolare sopra il poema eroico, estampado em 1587, trata-se do tipo que se notabiliza exemplarmente pela suma virtude: Eneias notabiliza-se pela piedade, Aquiles, pela fortaleza em combate, Ulisses, pela prudência, Amadis de Gaula, pela lealdade, e Bradamante, pela constância".

${ }^{271}$ Lê-se, na Retórica a Herênio (1997, pp. 71-72): “A invenção é a capacidade de encontrar argumentos verdadeiros ou verossímeis que façam a causa conveniente. A disposição ordena e distribui os argumentos e mostra o lugar em que cada um deles deve ser situado. $O$ estilo serve para adaptar os argumentos da invenção às palavras e frases apropriadas. A memória consiste em reter com segurança na mente as ideias e palavras e a sua disposição. A representação é a capacidade de regular a voz, o rosto e os gestos de maneira agradável".
} 
Luís Verney (1991, p. 80) reconhecia o papel imprescindível da retórica. Ele advertia que:

\begin{abstract}
Muito necessário é estudar a natureza; estudar o caráter das paixões; falar naturalmente; que só assim se fala eloquente e só assim se persuade. Este é o primeiro ponto, ou o mais importante, em matéria de Retórica. O segundo, e de não menor consequência, está em saber proporcionar o estilo ao argumento que se trata. Consiste o estilo em certas maneiras de se explicar a certas particulares expressões que cada homem usa (...) se deve regular segundo a matéria que se trata. As expressões magníficas e nobres ornam as coisas de uma certa majestade e mostram o grande conceito que delas forma quem assim fala.
\end{abstract}

No final do Setecentos, Hugh Blair (2005, p. 266) redefiniu a arte de falar em público, como sinônimo para Eloquência. Para o inglês, essa arte conteria "três graus": o primeiro e mais baixo, aquele que objetiva agradar os ouvintes, meramente - como era o caso dos panegíricos, orações inaugurais etc. Um segundo, e elevado grau, envolveria não só agradaria, mas também informaria e educaria os ouvintes. O terceiro, e mais elevado grau, seria aquele em que o discurso do orador comoveria os ouvintes, arrastando-os em diferentes paixões, e portanto, para outras direções, envolvendo-os mais intimamente com a fala, fosse ela resultante de debates em assembleias, quanto em discursos e sermões a partir do púlpito. Seis anos depois dele, Ignácio de Luzan (1789, p. 310) declarava: "É mister (...) que o poeta cuide também das palavras e da elocução, cuja beleza consiste na eleição de vozes e em sua acertada colocação. A perspicácia e claridade da oração, a propriedade e pureza das vozes são as principais virtudes da elocução". Seria conveniente examinar de perto a voz que narra enuncia o Caramuru. Para isso, lembremos a recomendação de Longino (OLIVEIRA, 1984, p. 57), que elegeu a "frase nobre" como uma das "fontes da Sublimidade". Segundo o tratadista, ela se constrói a partir da "escolha de vocábulos e a diç̧ão elegante e figurada".

Verney (1991,p. 82) assinalava ainda que: “Esta magnificência de expressões grandiosas e harmoniosas convém ao estilo sublime, com a distribuição dita de aplicar as melhores às coisas que merecem maior atenção. Também no estilo sublime devem entrar reflexões judiciosas e várias sentenças que excitem a atenção". Há numerosas 
passagens do poema que correspondem à lição do filósofo. Um dos episódios mais relevantes envolve o diálogo entre Diogo Álvares Correia e Gupeva:

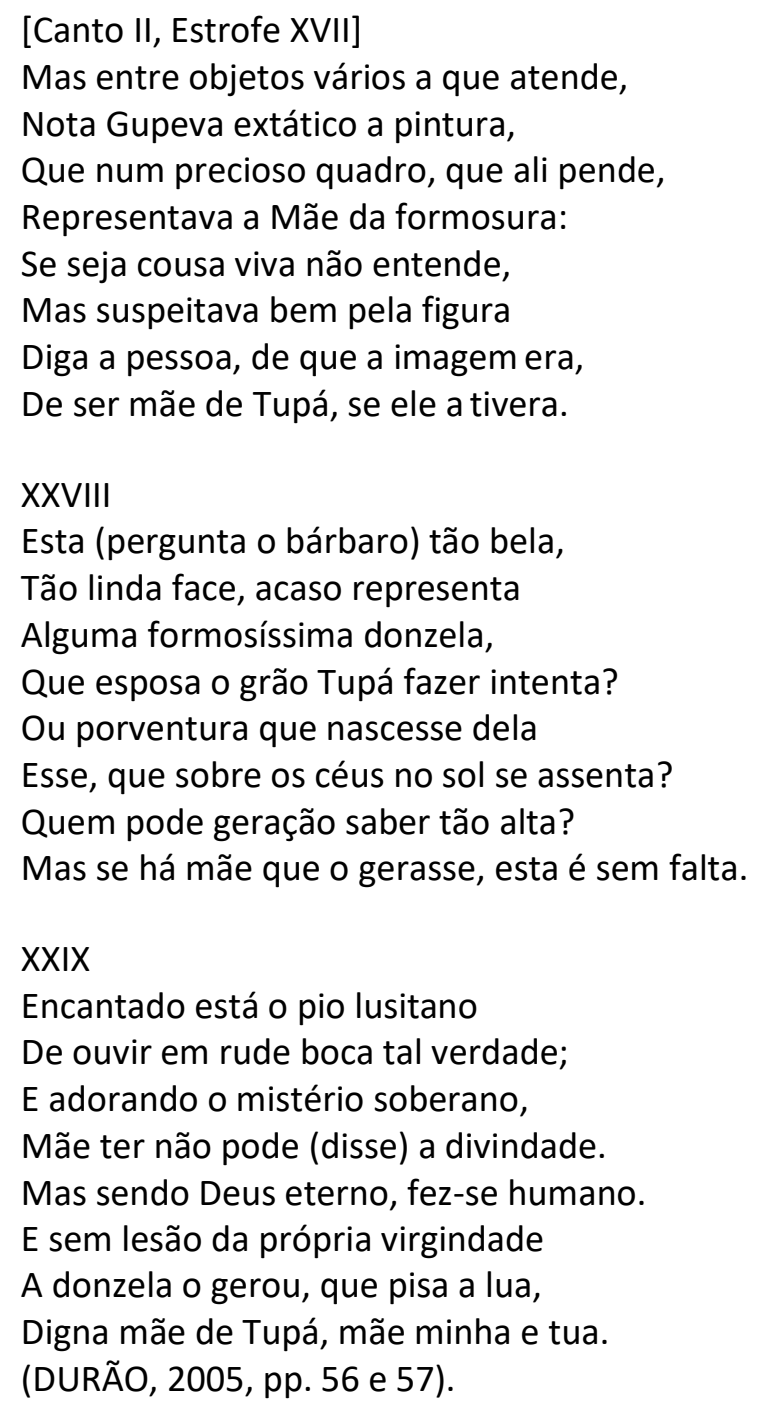

Inicialmente, Santa Rita Durão atribui a Gupeva o sentimento de orfandade espiritual. Como a religião tupinambá não previa adoração à mãe de Jesus Cristo, Diogo compartilha com ele a figura de Maria. A intenção é persuasória: Durão reafirma a sua fidelidade à igreja; reforça o caminho da fé católica; atribui ao branco a tarefa de converter o índio. Para obter maior consistência nos argumentos, antes de colocar o índio ao lado do português ("mãe minha e tua"), a rezar na capela, descreve a postura extasiada do guerreiro, diante da imagem. Aos atributos externos de Maria ("tão bela") somam-se os morais ("formosíssima donzela"). Ut pictura poesis. O retrato da virgem não cabe em palavras. Os versos ressoam também os ensinamentos de Horácio (1984, p. 
55), que recomendava manutenção da unidade, com vista a assegurar e tornar mais eficazes os efeitos pretendidos pelo poeta:

[...] forcejo por ser breve, em obscuro me torno; a quem procura o estilo polido, faltam a força e o calor, e todo o que se propõe atingir o sublime, descamba no empolado. Acaba, todavia, rastejando pelo chão o demasiado cauto, o que tem medo da procela; mas quem deseje variar prodigiosamente um tema uno, pintará golfinhos nas florestas e javalis nas ondas do mar. Procurando fugir do engano se cai no erro, caso não se possua a arte.

O fato de José de Santa Rita Durão ser eremita da Ordem de Santo Agostinho talvez explique a ênfase na conduta relativamente pacífica do herói discreto e ponderado, tal como foi pintado Diogo Álvares. A sua bravura, como guerreiro, só é acionada quando defende o novo território que lidera. Os métodos do herói por vezes dialogam com os líderes indígenas em disputa: "Era Sergipe o príncipe valente / Na esquadra valerosa, que atacava; / Varão entre os seus bom, manso e prudente, / Que com justiça os povos comandava" [Canto I, Estrofe XC]. (DURÃO, 2005, p. 45). Para reforçar a visão harmonizadora do português, náufrago corajoso, industrioso e civilizador, o poeta leva-o a pronunciar-se com sabedoria, imbuído que está pela graça divina. Diogo revela energia, graças à vocação expansionista; age retamente, pois reproduz valores da religião católica, que promete o "caminho, a verdade ${ }^{272}$ e a vida"; procede de modo elevado, em dupla conveniência (moral e estilística), conveniente ao gênero épico. Ricardo Valle (2009, p. 11) considera que, até o final do século XVIII, "Por meio da ficção verossímil cheia de verdades da épica em geral e da épica cristã em especial, entendia-se que se podia inculcar coragem na alma dos jovens".

Sob tais aspectos, será determinante atentarmos para a linguagem. A observância do decoro, na composição do Caramuru, começa pelo léxico: o poeta escolhe palavras que nobilitam as ações descritas nos versos, como se vê na estrofe XXVII do primeiro canto: "Diogo então, que à gente miseranda, / Por ser de nobre sangue precedia (...) Serviu-se por bastão de uma espingarda" (DURÃO, 2005, p. 21).

\footnotetext{
272 "[...] há duas espécies de verdade. Uma, que de fato é o que realmente aconteceu; outra que, de modo verossímil, é ou foi, ou poderia e deveria ser, segundo as forças e o curso regular da natureza. A primeira verdade buscam-na os teólogos, os matemáticos e outras ciências, como também a história; a segunda pertence aos poetas, aos retóricos e, às vezes, os historiadores" (LUZÁN, 1789, p. 143).
} 
Dessa ótica, seria possível compreender o poema como ilustração de outro ensinamento de Longino (OLIVEIRA, 1984, p. 59): “[...] nada faz mais sublime a oração do que um afeto nobre, onde é próprio, o qual parece, como uma inspiração e furor divino e em certo modo a enche de divindade". Como nota Luciana Gama (2003, p. 129): “Adequadas à matéria, a articulação bem como a elocução dos instrumentos dos indígenas no Caramuru são hiperbólicas e bem-dispostas. Imagem e som devem confluir".

Ao retratar Paraguaçu, Santa Rita Durão pinta-a como branca, virginal e elegante e, desse modo, supõe elevá-la acima da condição dos índios, descritos como escuros, pecadores e rudes ${ }^{273}$. Adequada e proporcional ao gênero sublime, Paraguaçu está para Maria, a virgem mãe de Deus, assim como Diogo está para o valoroso Rei Manuel I-a reforçar a dupla sujeição dos índios: à religião católica (que os governa espiritualmente) e à política reinol, como definia o conceito de corpo místico ${ }^{274}$. Ao adotar esse artifício, o poeta não só moldou a personagem contrapondo-a aos índios; buscava fidelizar o interlocutor de seu tempo, que pressupunha a "natural superioridade" moral e intelectual dos brancos em relação aos índios. Essa questão não era estranha aos homens letrados que seguiam a carreira jurídica: afora o diploma obtido em Direito Civil ou Canônico, também havia a prova em que atestavam a pureza de sangue. São muitas as implicações relacionadas ao retrato de Paraguaçu ${ }^{275}$ :

\footnotetext{
273 Leonardo Zuccaro (2019, pp. 18-19) observa que: “'Descrição', em português, tem como étimo descriptio. 0 vocábulo latino, por sua vez, era usado para verter diversos outros do grego antigo, caso semelhante ao da figura, exposto por Auerbach num verdadeiro trabalho de lexicologia. Descriptio poderia ser o vocábulo equivalente na acepção do grego antigo diagraphía, substantivo derivado do verbo diagráphō, que é 'descrever em detalhes, com todas os limites demarcados', ou também 'delinear'. É encontrado, na maior parte das vezes, em textos legais, em contextos judiciais e deliberativos, como nas Leis de Platão (Lg. 778a), mas também em Políbio (1. 62. 7), e em orações de Lísias $(17,5)$ e Demóstenes $(18,25 ; 48,26)$, e que em Cícero passou a ser descriptio, próximo do que é para nós 'transcrever' (cf. Ep. ad Fam. 12,17,12). Apesar disso, podemos encontrá-lo também em Aristóteles, na Retórica (Rhet. 1378a). Este verbo, por ser derivado do substantivo diágramma (que significa em português, dentre outras coisas, 'figura geométrica'), também deriva tanto de graphía ('desenho' e, posteriormente, 'escrita'), como do verbo gráphō, que, além de 'desenhar' ou 'escrever' (sendo que grámma pode significar 'letra'), em um contexto matemático significa também 'descrever figuras geométricas', como nos Elementos de Euclides e em Arquimedes (cf. Euclid. Post. 3; Archim. Sph. Cyl. Def. 1; Fluit. 2.4). Deriva daí a geometria descritiva”. 274 "A doutrina corporativa da Igreja Romana foi sumarizada e dogmatizada em 1302, pelo Papa Bonifácio VIII nas sentenças lapidares da bula Unam sanctam (...) O contexto geral da bula não deixa dúvida quanto ao sentido da sentença introdutória. Ela revela o esforço supremo, da parte do poder espiritual de responder e, se possível, sobrepujar o desafio da incipiente autossuficiência dos corpos políticos seculares" (KANTOROWICZ, 1997, p. 194).

275 De acordo com Antônio Manuel Hespanha (2006, p. 52), no Antigo Regime "tende-se a distinguir, dentro do povo, os estados 'limpos' (como o dos letrados, lavradores, militares) dos estados 'vis' (como os
} 
[Canto II, Estrofe LXXVIII]

Paraguaçu gentil (tal nome teve),

Bem diversa de gente tão nojosa,

De cor tão alva como a branca neve,

E donde não é neve, era de rosa:

O nariz natural, boca mui breve,

Olhos de bela luz, testa espaçosa;

De algodão tudo o mais, com manto espesso,

Quanto honesta encobriu, fez ver-lhe o preço.

(DURÃO, 2005, p. 75).

Afinado com a auctoritas camoniana, no poema, Durão sugere que Diogo Álvares Correia acumula virtudes de homem enérgico e ordeiro, súdito e fiel, o que se reflete no longo diálogo inicial que trava com os índios - ocasião em que reafirma sua posição "superior" e estabelece lugar e poder de mando, pelo discurso. Moralmente falando, as qualidades do herói ${ }^{276}$ se confirmam pelo fato de ter recusado a poligamia - costume tido por bárbaro e avesso ao dogma católico ${ }^{277}$ - ao tomar Paraguaçu como primeira e única esposa. Porém, a união com a índia não assegura a paz ao casal e, por extensão, a tribo. O lirismo se imiscui à temática da guerra, em possível alusão ao Uraguai, de Basílio da Gama (1769). Envolvidos nas constantes batalhas entre tupinambás e tapuias, a jovem também era desejada por Jararaca, líder da tribo rival:
[Canto IV, Estrofe I]
Era o invasor noturno um chefe errante, Terror do sertão vasto e da marinha, Príncipe dos caetés, nação possante, Que do grão Jararaca o nome tinha: Este de P'raguaçu perdido amante, Com ciúmes da donzela ardendo vinha:

oficiais mecânicos e artesãos). É este o sentido da classificação de um jurista seiscentista português, Melchior Febo - 'no que respeita à nobreza (secular), existem três estados: um[,] o nobre, outro[,] o mecânico e artesão, o último, o dos privilegiados que, pela milícia ou pela arte se libertam das profissões sórdidas". Nuno Camarinhas (2012, p. 206) lembra que: "O segundo critério fundamental que determinava o ingresso na carreira [jurídica] era que o candidato demonstrasse pureza de sangue. (...) Concluída a formação universitária, além de dois anos de práticas em tribunais, os candidatos solicitavam ao Desembargo do Paço a instauração de inquéritos sobre sua pureza de sangue".

276 "No que se refere às propriedades do herói, Freire recomenda que se ponham em evidência os costumes 'raros', 'sublimes' e 'admiráveis'. A bondade moral é importante porque o herói épico deve ser um exemplo a se copiar. Daí a 'prudência', a 'generosidade', a 'força' e principalmente o 'valor na guerra'. Ora, se observarmos os adjetivos que acompanham Diogo, veremos que denotam heroísmo, nobreza e força”" (BIRON, 2003, p. 330).

277 "Os historiadores gostam de citar uma famosa passagem de Tertuliano, o grande apologista que viveu entre os séculos II e III depois de Cristo; e trata-se de uma citação oportuna: a comunidade dos cristãos é um corpus, ou seja, é uma realidade orgânica e unitária, graças a três elementos de coesão: a crença na mesma fé, a esperança comum na salvação eterna e a unidade disciplinar" (GROSSI, 2014, p. 137). 
Ímpeto que à razão, batendo as asas,

Apaga o claro lume e acende as brasas

(DURÃO, 2005, p. 119).

O modo como o poeta descreve as armas aportadas pelos guerreiros prenuncia a violência dos confrontos, sem que se descuide dos artifícios que elevem o nível da linguagem, adequando-a ao estilo grave, que caracteriza o gênero épico:

\author{
[Canto IV, Estrofe XXVI] \\ Em guerreiras colunas, feroz gente, \\ Que no horror da figura assombra tudo, \\ Trazem por armas uma maça ingente, \\ Tendo de duro lenho um forte escudo; \\ Frechas e arco no braço armipotente, \\ Nas mãos um dardo de pau-santo agudo, \\ Sobre os ombros a rede, à cinta as cuias, \\ Tal era a imagem dos cruéis tapuias. \\ (DURÃO, 2005, p. 129).
}

Neste, e em outros episódios, as aliterações $(/ \mathrm{r} /$ e $/ \mathrm{m} /)$ parecem reforçar os rascantes sons de luta renhida. Combinada às onomatopeias, o poeta foge ao estilo humilde (GOMES, 2020) e a à dicção coloquial, recorrendo ao hipérbato e à hipérbole no primeiro verso ("Em guerreiras colunas, feroz gente"). ${ }^{278}$ Mas talvez o embate mais importante seja aquele travado entre marido e esposa, entre as estrofes $\mathrm{V}$ e $\mathrm{XI}$ do Canto V:

\author{
[Canto V, Estrofe IX] \\ Desde a origem da imensa eternidade, \\ Que tudo sem princípio ordena e rege, \\ Devemos presumir da Divindade \\ Que onde o ótimo encontra, em tudo o elege; \\ E sendo em nós tão grande a iniquidade, \\ Não temos cousa que a qualquer nos inveje, \\ Onde se os mais possíveis vendo fores, \\ Nós fomos os eleitos por melhores.
}

\footnotetext{
278 Durão afeta humildade nas "Reflexões Prévias e Argumento", com que apresenta o poema, no que parece aplicar o recurso da captatio benevolentiae, recomendado pela retórica tradicional: "[...] espero as repreensões, para, se for possível, emendar os defeitos" (DURÃO, 2005, p. 5). Como salienta Maria Fernandes de Carvalho (2209, p. 11): "A disposição desses discursos preambulares interfere no decoro da obra em si, compondo parte de sua autoridade".
} 
Estrofe X

Embora seja assim (disse a donzela);

Mas que culpa têm estes, que o ignoravam?

Não cuida acaso Deus, ou pouco zela

As almas, que entre nós se condenavam?

E senão, porque causa aos mais revela

As doutrinas que aos nossos se ocultavam?

Distava mais do céu a nossa gente,

Porque medeia o mar d'este a poente?

(DURÃO, 2005, p. 154).

Um leitor desavisado poderia inferir que Santa Rita Durão, homem de alma pia e intenções retas, estivesse a dar maior razão à indígena. Talvez esse episódio seja a oportunidade de sugerir justamente o contrário. Desde os versos iniciais, é a voz do herói português (que, sintomaticamente, nomeia o poema) que mais se escuta. Entre os feitos do reino e as providências divinas, o herói não só enfrenta guerreiros ferozes, mas também fortes oponentes no âmbito do discurso. Haveria que se pensar por que Santa Rita Durão concedeu a Gupeva e a Paraguaçu a rara capacidade de refutar os argumentos apresentados por Diogo. Porventura fosse um modo de simular equidade de falas entre os índios e o homem branco. De todo modo, ficando invariavelmente com a palavra final, os contrapontos apresentados pelos nativos resultam impotentes. A concepção de mundo previa o Deus católico, apostólico e romano, que se fundia ao projeto de expansão do reino português. Nesse sentido, pouco há de mais prepotente, no Caramuru, que estes versos ao final do Canto VI: "Não foi acaso (disse o herói prudente), / Respondendo ao discurso), foi destino / Querer o grão Tupá que a vossa gente / A mão conheça do poder divino" (DURÃO, 2005, p. 176).

Vizinho do discurso historiográfico, no século XVIII o gênero épico compartilhava com aquele a pretensão à verdade e o fato de ser escrita, na quase totalidade dos casos, pelos homens mais afortunados, ou próximos aos poderes que emanavam do rei. Por intermédio dos versos, o poeta reafirma lealdade "[...] à soberania do rei, louvada na alegação das misérias sofridas e dos méritos acumulados de que o próprio poema tem interesse em ser uma atestação" (VALLE, 2009, p. 114 - grifo do autor). Nesse sentido, a epopeia contém expedientes artificiais e também acena para o direito civil e canônico. Amparada pela narração tida por honesta, civilizada e bem-intencionada, a historiografia seria fidedigna aos eventos transcorridos; por sua vez, o poema épico concederia vivacidade e outros recursos de ênfase, onde faltava colorido. Talvez porque 
situado entre a história e a poesia; porventura, por ser mais extenso e grandiloquente que a epopeia de Basílio da Gama, Caramuru ainda carece de leitores capazes de reconhecer nele um poderoso diálogo com os textos que circularam em seu tempo e lugar, fossem eles aparentemente contra a Ordem da Companhia de Jesus, fossem em simulada defesa dos índios. 


\section{Referências}

ALI, S. Versificação Portuguesa. São Paulo: Edusp, 2006.

AQUINO, [Santo] T. de. A Prudência. Trad. Jean Lauand. São Paulo: Martins Fontes, 2005.

Suma Teológica, Volume VIII. 2. ed. São Paulo: Loyola, 2009.

ARISTÓTELES. Retórica. Trad. Manuel Alexandre Júnior; Paulo Farmhouse Alberto; Abel do Nascimento Pena. São Paulo: Martins Fontes, 2012.

BANDEIRA, M. Apresentação da poesia brasileira: seguida de uma antologia. São Paulo: Cosac Naify, 2009.

A Versificação em Língua Portuguesa. In: Seleta de Prosa. Rio de Janeiro: Nova Fronteira, 1997, pp. 533-557.

BIRON, B. R. R. Luzes, Razão e Fé em Caramuru. In: TEIXEIRA, Ivan (org.). Épicos. São Paulo: Edusp/Imprensa Oficial, 2008, pp. 317-354.

BLAIR, H. Lectures on Rhetoric and Belles Lettres. Carbondale: Southern Illinois University Press, 2005.

BOSI, A. Cultura. In: CARVALHO, J. M. de. (org.). História do Brasil Nação, Volume 2: A Construção Nacional (1830-1889). Rio de Janeiro: Objetiva, 2012, pp. 225-279.

BUENO, A. Uma História da Poesia Brasileira. Rio de Jandiro: G. Ermakoff, 2007.

CAMARINHAS, N. Les Magistrats et L'Administration de la Justice: Le Portugal et son Empire Colonial (XVII-XVIII' siècle). Paris: L'Harmattan, 2012.

CAMBI, F. História da Pedagogia. Trad. Álvaro Lorencini. São Paulo: Editora Unesp, 1999.

CANDIDO, A. O Passadista Santa Rita Durão. In Formação da Literatura Brasileira (Momentos Decisivos) - 10 Volume (1750-1836). 9. ed. Belo Horizonte: Itatiaia, 2000, pp. 169-178.

CARVALHO, M. do S. F. de. Preambulares do Livro Seiscentista em Portugal e no Brasil. Piauí: Eudpfi; Fapepi, 2009.

CARVALHO, R. de. Pequena História da Literatura Brasileira. 13. ed. Rio de Janeiro: F. Briguiet \& Cia, 1968.

CÉSAR, G. Historiadores e Críticos do Romantismo, V. 1. São Paulo: Edusp, 1978. 
CÍCERO, M. T. Dos Deveres. Lisboa: Edições 70, 2017.

CORTESÃO, J. “A Carta” de Pero Vaz de Caminha. Lisboa: INCM, 1994.

ELIAS, N. A Sociedade de Corte: investigação sobre a sociologia da realeza e da aristocracia de corte. Trad. Pedro Süssekind. Rio de Janeiro: Zahar, 2001.

FELIPE, C. V. do A. O Conde de Monte-Cristo e a catábase de Edmund Dantès, 2020 (no prelo), 20 p. [PDF]

GAMA, L. A Retórica do Sublime no Caramuru: Poema Épico do Descobrimento da Bahia. Revista USP, n. 57, São Paulo, pp. 122-137, 2003.

GÂNDAVO, P. de M. de. A Primeira História do Brasil: História da Província de Santa Cruz a que vulgarmente chamamos Brasil. 2. ed. Rio de Janeiro: Zahar, 2004 (Org. Sheila Moura Hue; Ronaldo Menegaz).

GODINHO, V. M. A Estrutura na Antiga Sociedade Portuguesa. Lisboa: Editora Arcádia, 1971.

GOMES, H. S. Figura de Marília. São Paulo: FFLCH/USP, 2020. Dissertação de Mestrado [em curso]. Orientação: Jean Pierre Chauvin.

GONZAGA, T. A. Tratado de Direito Natural. São Paulo: Martins Fontes, 2004 (Org. Keila Grinberg).

GRACIÁN, Baltasar. Oraculo Manual y Arte de Prudencia. In: Obras Completas. Madri: Cátedra, 2011, pp. 339-430.

GROSSI, P. A Ordem Jurídica Medieval. Trad. Denise Rossato Agostinetti. São Paulo: WMF Martins Fontes, 2014.

GROTIUS, H. The Rights of War and Peace. Trad. A. C. Campbell. New York; London: M. Walter Dunne Publisher, 1901 [EPUB].

HANSEN, J. A. Autor. In: JOBIM, José Luis. Palavras da Crítica: Tendências e Conceitos no Estudo da Literatura. São Paulo: Imago, 1992, pp. 11-43.

. Notas sobre o Gênero Épico. In: TEIXEIRA, I. (org.). Épicos. São Paulo: Edusp/Imprensa Oficial, 2008, pp. 17-91.

. Razão de Estado. In: . Agudezas Seiscentistas e Outros Ensaios. São Paulo: Edusp, 2019a, pp. 75-96 (Org. Cilaine Alves Cunha e Mayra Laudanna).

. O Discreto. In: Agudezas Seiscentistas e Outros Ensaios. São Paulo:

Edusp, 2019b, pp. 97-122 (Org. Cilaine Alves Cunha e Mayra Laudanna). 
HESPANHA, A. M. O Direito dos Letrados no Império Português. Florianópolis: Fundação Boiteux, 2006.

HOLANDA, S. B. de. O Mito Americano. In: CANDIDO, Antonio (org.). Capítulos de Literatura Colonial. São Paulo: Brasiliense, 1991, pp. 79-115.

HORÁCIO. Arte Poética ou Regras da Verdadeira Poesia em Geral e de Todas as Suas Espécies. Trad. R. M. Rosado Fernandes. Lisboa: Inquérito, 1984.

KANTOROWICZ, E. H. The King's Two Bodies: a Study in Mediaeval Political Theology. New Jersey: Princenton University Press, 1997.

LIMA, O. Formação História da Nacionalidade Brasileira. 3. ed. Rio de Janeiro: Topbooks; São Paulo: Publifolha, 2000.

LIPOVETSKY, G. Tempos Hipermodernos. Trad. Mário Vilela. São Paulo: Barcarola, 2004.

LUZÁN, I. de. La Poética, Ó Reglas de la Poesía en General, y de sus Principales Especies. Madri: Imprenta de Don Antonio de Sancha, 1789.

MAIA, P. (org.). "Ratio Studiorum": Método Pedagógico dos Jesuítas. São Paulo: Edições Loyola, 1986.

OLIVEIRA, C. J. de. Tratado do Sublime de Dionísio Longino. Lisboa: INCM, 1984.

PINTO, R. G. de O. Doutrina do misto e anatomia do monstro: usos da retórica de Hermógenes entre os séculos XVI e XVIII. São Paulo: FFLCH/USP, 2015. Tese de Doutorado. Orientação: Adma Fadul Muhana.

POLITO, R. Introdução. In: DURÃO, Santa Rita. Caramuru: Poema Épico do Descobrimento da Bahia. 2a ed. São Paulo: Martins Fontes, 2005, pp. IX-XLVIII.

RETÓRICA a Herênio. Trad. Salvador Núñez. Madri: Gredos, 1997.

RIBEIRO, R. J. A Etiqueta no Antigo Regime. 3. ed. São Paulo: Brasiliense, 1990.

ROMERO, S. História da Literatura Brasileira - Tomo 10 (1500-1830). 2. ed. Rio de Janeiro: H. Garnier, 1902.

RUIZ, R. Francisco de Vitoria e o Direito dos Índios Americanos. Porto Alegre: EDIPUCRS, 2002.

SALVADOR, [Frei] V. de. História do Brasil (1500-1627). São Paulo: Melhoramentos, 1965. 
SILVEIRA, M. A. da. O Universo do indistinto: Estado e Sociedade nas Minas Setecentistas (1735-1808). São Paulo: Hucitec,1997.

SOUZA, C. C. E. de. Alvarenga Peixoto e(m) seu tempo. São Paulo: FFLCH/USP, 2017. Dissertação de Mestrado. Orientação: João Adolfo Hansen.

TEIXEIRA, I. Mecenato Pombalino e Poesia Neoclássica. São Paulo: Edusp, 1999. . Hermenêutica, Retórica e Poética nas Letras da América Portuguesa. Revista USP, n. 57, pp. 138-159, 2003.

VALLE, R. M. Instituições da Coisa Bélica. Tradições de Doutrina e Jurisprudência, Instituições Civis, Práticas Letradas, Guerra Justa e Matéria Heroica. São Paulo: FFLCH/USP, 2009. Tese de Doutorado. Orientação: João Adolfo Hansen.

VARNHAGEN, F. A. de. Ensaio Histórico sobre as Letras no Brasil. In: Florilégio da Poesia Brasileira, Tomo 1. Rio de Janeiro: ABL, 1946, pp. 9-48.

VERÍSSIMO, J. História da Literatura Brasileira: de Bento Teixeira (1601) a Machado de Assis (1908). 4. ed. Brasília: Editora UnB, 1963.

VERNEY, L. A. Verdadeiro Método de Estudar (Cartas sobre Retórica e Poética). Lisboa: Presença, 1991 (Org. Maria Lucília Gonçalves Pires).

ZUCCARO, L. O discurso evidente: Um estudo da descrição na obra impressa de Manuel Botelho de Oliveira. São Paulo: FFLCH/USP, 2019. Dissertação de Mestrado. Orientação: Adma Fadul Muhana. 


\section{Retórica, Controvérsia do Oitocentos}

For all good poetry is the spontaneous overflow of powerful feelings

(William Wordsworth) ${ }^{279}$

Resumo: Durante os Oitocentos, a palavra "retórica" foi empregada basicamente de duas formas, no Brasil: 1. Positivamente, como disciplina avalizada por instituições de prestígio, a exemplo do Colégio Dom Pedro II; 2. Pejorativamente, como predicado depreciativo de um certo modo de se expressar, tido por artificial, pomposo e inautêntico. Neste artigo foram discutidas as acepções do termo e também foram identificados alguns entre os atores que se manifestaram a respeito da arte da persuasão, a partir do século XIX.

Palavras-chave: Literatura Brasileira; Retórica; Discurso; Crítica.

Abstract: During nineteenth century, "rhetoric" it was a word used in two forms in Brazil: 1. Positively, as a discipline endorsed by some prestigious institutions, such as the Dom Pedro II; 2. Pejoratively, as a derogatory predicate of a certain way to express, considered like an artificial, pompous and inauthentic resource. In this article, we discuss the meanings of this term and locate some of the actors who expressed themselves about the art of persuasion since the 19th century.

Keywords: Brazilian Literature; Rhetoric; Discurse; Criticism.

\section{Artifício}

"Retórica" é palavra de uso controverso. Discussões em torno do termo remontam aos filósofos gregos, cinco séculos antes de Cristo - em particular nos diálogos transcritos por Platão, discípulo dileto de Sócrates. Em Górgias, o filósofo de Alopece contrapõe-se ao protagonista que nomeia o livro, sugerindo que a retórica era equiparável à culinária: ambas seriam artes do supérfluo. Em outra ocasião, Sócrates discutia sobre o exercício da técnica, questionando a isenção do sofista. Contratado e pago por seus alunos, o orador privilegiaria os efeitos, suscitados pelo discurso habilidoso, mas desprezaria a busca pela verdade:

Não se dá com o orador e a oratória o mesmo que com relação a todas as demais artes? Ela não tem precisão nenhuma de saber as matérias mesas na realidade;

279 “Porque toda boa poesia é um espontâneo transbordar de poderosos sentimentos" (WORDSWORTH, $1800, \mathrm{~s} / \mathrm{p}$ - tradução minha). 
basta-Ihe ter descoberto um artifício de persuasão, para, entre não sabedores, passar por saber mais do que os que sabem. (PLATÃO, 1970, p. 71).

Reexaminados os motivos para a ressalva de Sócrates, nota-se que a perspectiva tinha cunho moralizante. No diálogo com Górgias, o filósofo atrelava e condicionava o ofício do sofista ao emprego artificial e desvirtuado da palavra, resultando em uma fala viciosa. Para sair vitorioso de uma controvérsia, o orador seria capaz de simular a verdade e dissimular os expedientes a que recorria, ainda quando discorresse perante o grande público. Olivier Reboul contesta o antigo juízo de Sócrates:

[...] é aos sofistas que a retórica deve os primeiros esboços de gramática, bem como a disposição do discurso e um ideal de prosa ornada e erudita. Deve-se a eles a ideia de que a verdade nunca passa de acordo entre interlocutores, acordo final que resulta da discussão, acordo final que resulta da discussão, acordo inicial também, sem o qual a discussão não seria possível. A eles se deve a insistência no kairós, momento oportuno, ocasião que se deve agarrar na fuga incessante das coisas, ao que se dá o nome de espírito da oportunidade ou de réplica vivaz, e que é a alma de qualquer retórica viva. (REBOUL, 2000, p. 9).

Essa concepção algo maniqueísta começaria a mudar graças ao manual escrito por Aristóteles, décadas depois. Discípulo proeminente de Platão, ele discordava de seu mestre em diversos aspectos, entre os quais a caracterização e o emprego da retórica, que para ele tinha estatuto de arte legítima, e estaria sujeita, portanto, a um conjunto de regras. Parece haver acordo entre os especialistas de que Aristóteles foi o primeiro a sistematizar os preceitos e usos da retórica ${ }^{280}$. Uma diferença notável nos usos da arte da persuasão, durante o período medieval, comparativamente ao emprego defendido por Aristóteles, é que para o estagirita a retórica era uma arte de cunho pragmático que auxiliava os oradores, advogados, professores e poetas a expor ou defender causas, em acordo com o grau de justiça ou iniquidade; permitia tecer elogios ou vitupérios (pressuposto do gênero demonstrativo); estabelecia prioridades, em acordo com gênero deliberativo. Como observa João Adolfo Hansen:

\footnotetext{
280 "Se os sofistas emprestam a retórica para seu poder, Aristóteles a aprecia por sua utilidade. Com ele, ela não é mais aquela ciência da persuasão, apropriada para substituir os valores; ela se torna em meio de argumentar, com a ajuda de noções comuns e elementos de prova racional, a fim de levar um auditório a admitir as ideias" (ROBRIEUX, 1993, p. 11 - tradução minha).
} 
[...] a técnica retórica é arte de falar bem, não de falar o Bem ou a verdade. Desde Platão, a tensão e a guerra de "retórica" e "filosofia" aparecem em posições inimigas quanto à "autoridade" e à "autenticidade" da técnica. A desqualificação dela por Platão como doxastiké episteme, conhecimento opiniático, foi assumida por muito filósofo moderno, como Descartes, Locke, Kant, e continua reproduzida no senso comum que entende "retórica" como "não verdadeiro". Aristóteles é neutro na divisão dos domínios, provavelmente porque, como bom grego, sabia que o núcleo da sua sociedade era o ágon, a disputa, em que era fundamental a fala persuasiva. (HANSEN, 2013, p. 13).

Quer dizer, a ênfase não recairia exclusivamente sobre o caráter ético do orador, nem incidiria apenas no efeito moralizante das palavras, nem se reduziria ao efeito provocado pelo retor. A técnica pressupunha a articulação entre a performance do orador (que deveria projetar seu éthos no discurso), o logos (ilustrado pelo saber do próprio falante) e o estímulo às paixões do auditório (pathos). De acordo com Lineide Mosca:

O ponto fundamental da doutrina aristotélica, no que toca à Retórica, reside em considerá-la do domínio dos conhecimentos prováveis e não das certezas e das evidências, os quais caberiam aos raciocínios científicos e lógicos. Por essa razão, o seu campo é o da controvérsia, da crença, do mundo da opinião, que se há de formar dialeticamente, pelo embate das ideias e pela habilidade no manejo do discurso. (MOSCA, 2004, p. 20).

Com a redescoberta dos manuscritos da Retórica de Aristóteles, a edição Princeps no início do século $\mathrm{XVI}$, a arte da persuasão voltou com renovado vigor à cena intelectual europeia e motivou acalorados debates - por exemplo, entre ciceronianos e não-ciceronianos - pelas mãos dos homens mais representativos de seu tempo. As disputas filosóficas em torno de preceptivas também permearam as discussões da Igreja Católica, naquele período. Vale lembrar que, no final dos Quinhentos, a retórica também orientara a reformulação do ensino jesuítico, com vistas à padronização da catequese: "A Ratio studiorum não é apenas uma carta de ensino nos colégios dos jesuítas; ela integra, de pleno direito, a 'Instituição' da Companhia de Jesus, quer dizer, o conjunto dos textos oficiais que definem o estatuto religioso da Ordem, seu espírito e meios de colocá-la em ação." (RATIO, 1997, p. 26 - tradução minha). 281

\footnotetext{
281 De acordo com a Companhia da Ordem de Jesus, "A eloquência se reduz essencialmente a três elementos: as regras de expressão oral, o estilo e a erudição" (RATIO, 1997, p. 165).
} 
Classificada como uma das sete artes (Septivium) ${ }^{282}$ consideradas essenciais à formação dos irmãos da Ordem da Companhia de Jesus, ela foi seguida rigorosamente pelos homens que detinham a palavra santa e a aplicavam nos sermões e correspondências de modo sistemático. Assunto, disposição, expressão, performance e memória eram partes caudatárias da tradicional divisão retórica ${ }^{283}$, sistematizada durante a Antiguidade greco-latina.

Durante a Idade Média, quando o mundo ocidental se resumia praticamente à Europa, os nomes de Aristóteles, Cícero e Quintiliano circularam em grego, latim e línguas vernáculas em abadias, conventos, monastérios, cortes e academias ligadas às cortes. Compreendida como ferramenta, tanto de hermenêutica, quanto de exegese, a retórica passou a ser empregada como procedimento de cunho moralizante - no caso da igreja cristã. A retórica era concebida como valioso aparato técnico: conjunto de procedimentos a sustentar o teor e a estruturar sermões, correspondências e manuais de caráter didático ou instrucional.

Por outro lado, a arte também era aplicada na elaboração e organização de tratados desvinculados dos dogmas, que distinguiam engenho de agudeza, em favor da etiqueta cortesã (Baltazar Gracián) ${ }^{284}$ e embalavam diálogos polêmicos (como foi o caso de Erasmo de Roterdã, ao contestar a tradição ciceroniana) ${ }^{285}$. Entre os autores mais eruditos, algumas autoridades religiosas, como o espanhol Tomás Sánchez, "ensinavam" a mulher a se comportar no papel de esposa subserviente e responsável pela geração de herdeiros (CARRODEGUAS, 2003). No século XVII luso-brasileiro, a retórica amparou

\footnotetext{
282 “Na Idade Média, a 'cultura' é uma taxionomia, uma rede funcional de 'artes', isto é, de linguagens sujeitas a regras (a etimologia da época aproxima arte de arctus, que significa articulado) e essas 'artes' são chamadas 'liberais', porque não servem para ganhar dinheiro (em oposição às artes mechanicae, às atividades manuais): são linguagens gerais e requintadas. As artes liberais ocupam o lugar da 'cultura geral' que Platão recusava, em nome e em proveito somente da filosofia" (BARTHES, 1975, p. 165).

283 Inventio (encontrar o que dizer), Dispositio (dividir a matéria do discurso em partes), Elocutio (empregar expressão adequada com o gênero pretendido), Memoria (confirmar ditos e feitos com ações exemplares) e Actio (performar o discurso por meio da voz e do gestuário oratório). Eis uma das recomendações de Cícero: "Aquele que aspire ao primeiro posto na eloquência deverá pronunciar as partes violentas em tom agudo; em tom grave as partes calmas; e pronunciará o parecer sério com tonalidade profunda e patética, mediante inflexões da voz" (CICÉRON, 2010, p. 52).

284 "Toda potência intencional da alma goza de algum artifício em seu objeto; a proporção entre as partes do visível é beleza; entre os sons, consonância. Que até o gosto vulgar haja combinação entre o picante e o suave, entre o doce e o acre" (GRACIÁN, 2010, p. 139-140).

285 "De onde, pois, tirará o nome de ciceroniano, isto é, de melhor orador, aquele que fala de temas que não conhece profundamente e que não os expõe com o sentimento do peito, para não dizer claramente que os despreza e os odeia?" (ROTERDÃ, 2013, p. 96).
} 
a epistolografia, a parenética e a obra profética ${ }^{286}$, de Antônio Vieira. Alcir Pécora mostrou, ao estudar a farta correspondência do jesuíta, que o padre obedecia aos preceitos da Ars Dictaminis, discutida havia muitos séculos:

Nas cartas seriam particularmente importantes as diferenças decorrentes das posições sociais de autor e destinatário: se se escreve a superior, a carta não pode ser jocosa; a igual, não descortês; a inferior, não orgulhosa. Da mesma forma, as saudações e as despedidas devem manifestar diferenças de grau de amizade ou posição social (PÉCORA, 2001, p. 19).

James Murphy ressaltava que o gênero epistolar passou a ser discutido desde o século IV d.C., no trabalho de Gaius Julius Victor. Ciente de que a retórica tradicional não levava em conta o discurso coloquial, a intenção do retor latino era propor um conjunto de preceptivas aplicadas ao discurso informal (sermo), que também seriam aplicáveis à carta (epistola) do gênero familiar - de linguagem mais pessoal (MURPHY, 1974, p. 195).

\section{Verdade}

Como se sabe, àquela altura o Brasil era um pedaço do reino português situação que só começaria a mudar no final do século XVIII - momento em que as preceptivas começam a ser debatidas com vigor. Durante o Oitocentos, a arte da persuasão recebeu ataques os mais criativos e variados, que coincidiram com o advento da estética romântica. Embora recriminada nas esferas sociais, a Retórica era um dos esteios do ensino, especialmente nos estabelecimentos do Rio de Janeiro. Segundo Roberto Acízelo de Souza:

Durante o século XIX, há no Brasil, ao longo de um período que coincide quase integralmente com o ciclo do Império, um grande interesse pelos estudos de retórica (a que se anexam ou com que se confundem os de poética), interesse traduzido por várias publicações e pela inserção das disciplinas mencionadas nos currículos escolares. Observa-se, contudo, que esse interesse desaparece no final dos anos de 1880 , embora diversos resíduos dessa tradição se tenham conservado no século XX (SOUZA, 1999, p. 1).

\footnotetext{
286 Para os católicos em geral, como o mundo espiritual e o temporal eram regidos por Deus, não havia rigorosa distinção entre os tempos (Pretérito, Presente e Futuro). O gênero profético pressupunha a reprodução indefinida do presente, o que explica os pressupostos de Vieira, ao discorrer sobre o futuro (Cf. KOSELLECK, 2012).
} 
Na esteira de Ferdinand Denis (1826), poetas brasileiros, como Gonçalves de Magalhães e Gonçalves Dias, proclamavam a inobservância das tópicas greco-latinas e a ênfase no índio, alçado artificialmente ao posto de "herói americano" (DENIS apud GOMES; VECCHI, 1992). Desse modo, empenhados no projeto indianista - idealizado e financiado por Dom Pedro II e seu séquito - um comitê de homens tidos por notáveis concentrou-se em torno do IHGB, a exaltar e publicizar uma nova configuração do índio. Simultaneamente, e contrariando o discurso entusiástico do Instituto, o nativo era percebido ora como ameaça cultural, ora como empecilho econômico e civilizatório, como se lê em ensaios pseudocientíficos, disseminados nas assembleias e demais círculos de prestígio. Como assinalou a antropóloga Manuela Carneiro da Cunha, o discurso cientificista que chegava da Alemanha na primeira metade do século, combinado às sentenças de homens da confiança do Imperador, a exemplo de José Bonifácio ${ }^{287}$, resultou num discurso incompatível com as práticas adotadas pelo Estado:

[...] pode-se dizer que a questão indígena deixou de ser essencialmente uma questão de mão de obra para se tornar uma questão de terras. Nas regiões de povoamento antigo, trata-se mesquinhamente de se apoderar das terras dos aldeamentos. Nas frentes de expansão ou nas rotas fluviais a serem estabelecidas, faz-se largo uso, quando se o consegue, do trabalho indígena, mas são sem dúvida a conquista territorial e a segurança dos caminhos e dos colonos os motores do processo. (CUNHA, 2012, p. 56).

Paralelamente ao discurso inflamado de escritores, bacharéis e intelectuais nativistas de primeira hora - a retórica (já reduzida à disciplina "Eloquência", nos colégios) acompanhava a perspectiva utilitária de uma sociedade culturalmente rasa, forrada por arrivistas grosseiros, latifundiários recém-urbanizados, especuladores financeiros, e uma intelligentsia retroalimentada por teorias raciais que chegavam nos navios europeus. Durante os Oitocentos, a arte de "bem-dizer" (na definição de Quintiliano) confundia-se com a pompa dos oradores de mesa, canapé e tribuna. Na literatura, avulta o nome de Machado de Assis, que, segundo Maria Nazaré Lins Soares,

\footnotetext{
${ }^{287}$ Em 1827, José Bonifácio, então "presidente da província de Minas Gerais, ao ser indagado sobre a índole dos Aymorés e Botocudos, responde nos termos seguintes: 'de leões, leões se geram; e dos cruéis Botocudos (que devoram e bebem o sangue humano) só pode resultar prole semelhante'." (CUNHA, 2012, p. 59).
} 
"ridicularizou, através da sua [obra] todos aqueles que se compraziam em erguer no vazio estruturas verbais grandiloquentes, pensando com isso estar fazendo literatura" (SOARES, 1968, p. 5-6).

$\mathrm{Na}$ arena política, forjavam-se estratagemas e modos de dizer que pretendiam naturalizar a violência a ser aplicada na conversão ou extermínio dos Botocudos - índios cruéis, não integrados à civilização importada da Europa. A seu turno, as tribos Tupi e Guarani eram reconhecidas como grupos de índios pacíficos, já domesticados pela religião e conformados segundo a lei (SILVA, 1823). No plano historiográfico, assistia-se a um duvidoso pastiche dos manuais de Tácito e Tito Lívio. Valorizava-se o tom ufanista dos historiadores, empenhados em enaltecer o Imperador e a jovem nação. Todos proclamavam perseguir a verdade. É sugestivo que, um século após a primeira edição (1730), o manual de Sebastião da Rocha Pita fosse retomado como modelo de historiar ${ }^{288}$ - a reforçar, pela História, o discurso literário nativista.

O caso de Rocha Pita ilustra uma das contradições do tempo. Ao avaliar a sua obra, duas medidas foram aplicadas. Esquecido, quando não rebaixado como "poeta acadêmico"289, o historiador foi retomado como uma das primeiras vozes capazes de sacudir as liras - ou seja, as cordas interiores do leitor. Seu discurso historiográfico, datado e calcado em impressionismos, e redigido de modo impreciso e grandiloquente, foi considerado como expressão de seus "esforços escrupulosos para o fim de conseguir a verdade", como sugeriu Pereira da Silva, colaborador da Revista do IHGB, em 1849 (SILVA apud CHAUVIN, s/d, p. 270). Um estudo recente confirma a hipótese de Roberto Acízelo de Souza de que a acepção e o emprego da palavra "retórica" conflitavam, durante os Oitocentos. Reporto-me ao relevante trabalho de João Adalberto Campato Júnior, em que o pesquisador revela o recurso a expedientes retóricos na poesia épica de Gonçalves de Magalhães - porta-voz e símbolo do Romantismo nacional:

Na condição de homem de letras e de teórico empenhado na criação da obra ou poema nacional, Magalhães propugnava a seguinte fórmula com vistas à nacionalização romântica das letras, difusa em seus textos de caráter ensaístico e aplicada a suas obras: abordagem de assunto nacional, abandono do complexo

\footnotetext{
288 Isso se evidencia no livro que Joaquim Manuel Macedo escreveu para os alunos de história do Colégio Dom Pedro II, que atribui máximas virtudes a Dom Pedro II e a outros supostos "heróis" da nossa história. ${ }^{289}$ O Coronel Sebastião da Rocha Pita participou assiduamente das sessões da Academia Brasília dos Esquecidos, entre abril de 1724 e fevereiro de 1725, período em que compôs numerosos poemas de variados gêneros e temas.
} 
mitológico greco-latino, religiosidade cristã, celebração das belezas da natureza tropical, tematização do elemento indígena e respeito à inspiração na criação literária. Tal receita - a mesma, diga-se, de passagem, de outros intelectuais da época, como o francês Ferdinand Denis, o português Almeida Garrett e o brasileiro José de Alencar - Magalhães tentaria pôr em prática, principalmente, com A Confederação dos Tamoios. (CAMPATO JÚNIOR, 2014, p. 16-17).

Contrariando manuais tradicionais de literatura, Campato revela a distância entre o tom libertário proclamado pelo poeta e a arte supostamente desprovida de artifícios dos românticos. Para isso, selecionou diversos excertos do poema épico $A$ Confederação dos Tamoios, escrito sob encomenda do Imperador Pedro II, que também convidou o poeta para declamar os numerosos versos no Palácio Real. A solenidade e pompa do evento corroboram o elevado grau de artificialismo do projeto nativista e sugerem o caráter pouco "espontâneo" do poema:

Epopeia de feição clássica, $A$ Confederação dos Tamoios é devedora das épicas homérica, camoniana e das dos árcades brasileiros. O poema - elaborado em 1837, concluído em 1854 e publicado em 1856 - é formado por dez cantos, em versos decassílabos, de finalidade moral, que tratam de ação heroica, pois de outra forma não podem ser denominadas a brava luta e a valente resistência dos gentios contra os portugueses. (CAMPATO, 2012, p. 17).

Outro fator que rivalizava com a retórica era a crença de que a poesia ultrarromântica resultasse da honestidade e espontaneidade do escritor: sujeito particularmente sensível aos elementos da natureza (em oposição a "artifício") e que se confundia com a persona que ele inventara para o melhor versejar. ${ }^{290}$ José Veríssimo parecia acreditar que "A inspiração poética, como a forma que a realiza, ou o estilo, é função do temperamento do poeta que a condiciona." (VERÍSSIMO, 1963, p. 151). Quando se refere à numerosa obra de Joaquim Manuel de Macedo, sentencia injustamente que os seus romances "são todos talhados por um só molde" (VERíSSIMO, 1963, p. 173). ${ }^{291}$

\footnotetext{
290 “[...] deve cair fora a noção idealista, rotineira em manuais, que propõe a 'Retórica' como forma-matriz e expressão de uma história cíclica do Espírito Humano, que seria retórico, artificioso, complicado, formalista, sofístico, obscurantista e regressivo durante algum tempo, e não-retórico, natural, singelo, filosófico, verdadeiro, ilustrado e progressista em outro, para reencarnar espiritualmente retórico etc." (HANSEN, 2013, p. 14).

291 José Veríssimo teria lido A Luneta Mágica? É possível que não, o que explicaria seu equivocado juízo, ao nivelar "todas" as obras do romancista, baseado no enredo singelo de $A$ Moreninha etc.
} 
Para além da hipótese de que os poetas estivessem a desentranhar verdades, Francisco Achcar sugeriu que a estreita correlação entre biografia, honestidade e arte seria facilmente desmontável: "Para os que, a partir do romantismo, concebem o eulírico de forma substancial e associam diretamente o enunciado lírico à experiência subjetiva do poeta, um problema que logo se coloca é o do sentido da lírica: por que e em que o particular assume significação geral?” (ACHCAR, 1994, p. 37).

Não seria tarefa complexa descobrir numerosas convenções estéticas e ideológicas na poesia romântica. A recusa aos temas, gêneros e modelos greco-latinos não se efetivou, para além dos ensaios panfletários. Seria um equívoco repetir, ainda hoje, a premissa de que os escritores daquele período fossem mais (ou menos) afeitos à verdade, que os seus predecessores. A larga utilização do soneto, quando compunham poemas de temática lírica; o recurso ao gênero épico, para descrever sangrentas batalhas entre índios e portugueses, sugerem justamente o contrário.

\section{Retórica contra Retórica}

Outra contradição em torno da arte retórica reside no fato de que, embora constituísse disciplina obrigatória nos cursos escolares e universitários, a partir do século XIX, ela fosse questionada por jornalistas e escritores, no início do século seguinte. Até isso acontecer de modo mais explícito, o auditório da corte cindia-se entre a admiração pela lábia do orador e a ressalva frente ao discurso empolado frequentemente manejado por "doutores" intelectualmente medíocres, a disfarçar a falta de engenho com o discurso mais floreado.

Na virada para 1900, determinadas obras passariam as ser interpretadas como repositório da expressão preciosista, o que comprometeria a distinção entre homem, autor e persona artística. A boa literatura corria o risco de se ver nivelada ao discurso formalista e oco. Não por acaso, os parnasianos foram escolhidos como alvos prediletos dos modernistas, a partir da década de 1910. Sinal dos novos velhos tempos, o ensino de "Eloquência" começou a desaparecer das escolas, logo que a nossa Primeira Constituição Republicana foi proclamada: "1891 é o último ano em que a disciplina retórica, poética e literatura nacional consta do currículo, sendo substituída, a partir de 
1892, por história da literatura nacional, ano em que o galardão de livro oficial passa para a História da Literatura Brasileira de Sílvio Romero." (SOUZA, 1999, p. 43).

Duas possíveis vítimas do julgamento apressado, graças à linguagem considerada ornamentada, rebuscada e postiça, são José de Alencar e Raul Pompeia. Embora fossem muito populares em seu tempo, hoje ambos são estudados com menor afinco, talvez porque negligenciados por grande parte dos estudantes universitários, inclusive pesquisadores de literatura e colegas de ofício. Salvo artigos esparsos e raros trabalhos de fôlego em torno de sua obra, Alencar e Pompeia costumam ser recebidos com contorcionismos faciais, tanto na sala de aula quanto nos corredores. Curiosamente, quando se debruçou sobre o primeiro romance alencarino, mais uma vez a voz sobranceira de José Veríssimo abusou da generalização, espraiando seu julgamento para outros autores e movimentos:

[Alencar] Estreou em 1857 com uma obra-prima, que infelizmente não mais se repetiria em sua carreira literária, $O$ Guarani. Na literatura brasileira dá-se frequentemente o caso estranho de iniciarem-se os escritores com as suas melhores obras e estacionarem nelas, se delas não retrogradam. $O$ fato passouse com Alencar com o Guarani, com Macedo com a Moreninha, com Taunay com a Inocência, com Raul Pompeia com o Ateneu, com o sr. Bilac com as suas primeiras Poesias, e se está acaso passando com o sr. Graça Aranha com o seu Canaã. (VERÍSSIMO, 1963, p. 198).

Celebrada durante os Oitocentos, no século seguinte a obra de José de Alencar passou da popularidade ao questionamento; e deste ao relativo ostracismo, atualmente. E, no entanto, embora menos estudado que o necessário e devido, o cearense conta com novas e produtivas chaves de leitura, a exemplo de Eduardo Vieira Martins. Por adotar uma perspectiva que revitaliza os temas, reconsidera a forma romance e enfatiza o elemento estético, o pesquisador concluiu que, em O Guarani:

Essas longas descrições ou "cenas da natureza", como então eram chamadas, muitas vezes parecem excessivas para os leitores de hoje: são aqueles trechos que o aluno, curioso para conhecer a sequência da ação ou cansado da leitura, pula, em busca do fim da história. Se prestarmos atenção a elas, entretanto, podemos atribuir-Ihes três funções. Em primeiro lugar, a presença da natureza fornecia o elemento particular, a "cor local", que os românticos procuravam imprimir à literatura, acreditando com isso, contribuir para a sua nacionalização. Em segundo, deve-se destacar o aspecto, por assim dizer, musical dessas passagens. Nelas, o romancista procurava mostrar sua capacidade estilística, 
sua habilidade para criar um grande quadro poético [...]. Por fim, uma terceira função desses quadros é preparar a ação. (MARTINS, 2014, p. 21-22).

Como já sugerido, algo similar acontece nas análises sobre a obra maior de Raul Pompeia. Repitamos parte do percurso percorrido pela crítica. No início do século XX, José Veríssimo concedeu um meio elogio ao romance, aproximando o temperamento de Pompeia da dicção romanesca:

No que decididamente os sobreleva a todos [Aluísio Azevedo e Júlio Ribeiro] Raul Pompeia é, não só na maior originalidade nativa e na distinção, sob o aspecto artístico, do seu único romance, mas ainda no talento superior revelado na abundância, roçando acaso pela demasia, de ideias e sensações não raro esquisitas e sempre curiosas, que dão ao seu livro singular sainete e pico. Nesse livro, porém, que tantas promessas trazia e tantas esperanças despertou, parece se esgotou todo o engenho do malogrado escritor e espírito brilhantíssimo. (VERÍSSIMO, 1963, pp. 262-3).

Os casos de Alencar e Pompeia são emblemáticos. Reconhecidos como escritores de talento do século XIX, resistirão a novos modos de conceber literatura e língua, num país em que o esmero da linguagem, o sabor das descrições e a qualidade da obra dependem de maior dedicação e empenho dos leitores ao se aproximarem da obra literária? Uma célebre afirmação de Lúcia Miguel Pereira, de meados do século XX, poderia ser vista como cláusula no pacto de leitura, firmado entre romancista e leitor. Como se reverberasse o juízo de José Veríssimo, a estudiosa afirmou que $O$ Ateneu era um "romance estranho", que "[...] oscilava entre as insinuações de Machado de Assis e as ousadias dos naturalistas, variava no estilo da sobriedade ao rebuscamento." (PEREIRA, 1988, p. 108).

Afinal, a dificuldade para classificar Raul Pompeia guardaria relação com o seu relativo esquecimento pela crítica? Talvez seja precisamente o contrário. A linguagem deve estar em nosso horizonte interpretativo por diversos motivos. Será oportuno resgatar o ensaio de Alfredo Bosi, que descortinou o aparato discursivo em O Ateneu:

Raul Pompeia, inventor plástico, modelou as sequências da obra não como simples elos de uma cadeia temporal, mas como se cada episódio abrigasse em si um viveiro de figuras em plena arborescência. Daí vem uma saturação estilística, quase palpável, no esforço de dar vida aos ambientes onde se movem Sérgio, Aristarco, Ema, os meninos. Os nomes de objetos e de aspectos naturais, que se atulham em parágrafos densos, fazem mais do que transpor um cenário 
entre parnasiano e fin-de-siècle a decorar os espaços da trama; participam dessa mesma trama, pois jorram da memória em moto perpétuo de Sérgio adulto tão arroubadamente quanto invadiram, um dia, a fantasia de Sérgio menino (BOSI, 2003, p. 51-52).

Mais recentemente, Eliana Amaral chamou a atenção para dois aspectos relativos a 0 Ateneu: 1. A estrutura do enredo, a traduzir as angústias de Sérgio: "Tematizando no fundo o drama da solidão, o desajuste do indivíduo num ambiente que Ihe é hostil, a obra compõe-se de doze capítulos que se assemelham a uma sucessão de quadros, não subordinados linearmente entre si." 2. Outra produtiva chave de leitura se dá na "mistura entre ação e digressão" (AMARAL, 2005, p. 21-22). Ou seja, o aparente retardamento ou desvio da ação precisa ser analisado como sinal positivo, e não como passatempo inócuo. Metáfora e ironia são recursos recorrentes na obra de José de Alencar e Raul Pompeia. Senão, vejamos.

Descrito nas páginas iniciais do romance alencarino, seria o rio Paquequer uma metáfora dos índios a desbravar as matas e a percorrer sinuosamente os caminhos que os mantinham afastados da cidade (território mais poderoso, feito rio suserano?). "Dirse-ia que, vassalo e tributário desse rei das águas, o pequeno rio, altivo e sobranceiro contra os rochedos, curva-se humildemente aos pés do suserano." (ALENCAR, 2014, p. 51). Aproximado textual e imageticamente de seu mantenedor tirânico, seria o colégio Ateneu a versão em tijolos, vazio e pompa, de Aristarco? Observe-se como o narrador sintetiza os artifícios embutidos no discurso inflamado e gestos desmedidos do professor Venâncio - espécie de bajulador mor de Aristarco: "Um último gesto espaçoso, como um jamegão no vácuo, arrematou o rapto de eloquência." (POMPEIA, 2005, p. 46).

No romance de Alencar, a sugestiva aproximação entre o pequeno rio e o homem, a salvaguardar o aspecto "natural" dos indígenas, como contraposição ao grande rio - este, em correspondência com os artifícios da cidade "civilizada": "No ano da graça de 1604, o lugar que acabamos de descrever estava deserto e inculto: a cidade do Rio de Janeiro tinha-se fundado havia menos de meio século, e a civilização não tivera tempo de penetrar o interior." (ALENCAR, 2014, p. 52). Em Pompeia, a linguagem do narrador redunda em relato com dupla direção: uma a reproduzir textualmente o discurso acalorado e piegas do mestre; outra, a sugerir a grande distância entre o caráter 
falso e patético da peroração e as tiranias exercidas sistematicamente no tradicional colégio:

$O$ diretor recebeu-nos em sua residência, com manifestações ultra de afeto. Fezse cativante, paternal; abriu-nos amostras dos melhores padrões do seu espírito, evidenciou as faturas do seu coração. O gênero era bom, sem dúvida nenhuma; que apesar do paletó de seda e do calçado raso com que se nos apresentava, apesar da bondosa familiaridade com que declinava até nós, nem um segundo o destituí da altitude de divinização em que o meu critério embasbacado o aceitara (POMPEIA, 2005, p. 54).

Esses e outros enigmas foram construídos por meio da linguagem castiça, vigorosa e sugestiva - traços que irmanam a prosa de Alencar e Pompeia. Sob esse aspecto, torna-se difícil justificar o distanciamento dos leitores em relação a obras de inegável qualidade. Porventura continuaremos a supor que esses e outros escritores de grande talento teriam sido relegados ao relativo silêncio, em razão de seu discurso farto em adjetivos, advérbios e poderosas metáforas? Afora o valor intrínseco e o interesse histórico na arte da persuasão, não haverá dúvida de que um dos métodos mais eficazes de descortinar a diç̧ão de outra época é tomar contato com as preceptivas e matrizes culturais conhecidas e/ou empregadas por seus autores. Tomar contato com a retórica viabiliza demonstrar que o discurso de determinados narradores e personagens reproduz, no plano literário, a usual indistinção entre conteúdo, forma e expressão, como se o discurso em geral prescindisse de convenções, fórmulas e modos particulares de dizer.

Como convidar o aluno a que usufrua e se assenhoreie do texto literário, deslocando-se para um tempo, espaço e linguagens que não são os seus?

A questão não é ociosa. Um dos argumentos correntes, entre professores de literatura, é de que o público leitor de hoje não dispõe de vocabulário (nem repertório) suficiente para ler com maior fluência e fluidez os escritores de outros períodos históricos. Ora, a julgar pelos rumos de nossa Educação superior, quem garante que este não seja, em breve, o destino reservado à obra de Machado de Assis - a despeito de ser considerado um dos maiores representantes de nossa literatura, dentro e fora do país? 


\section{REFERÊNCIAS}

ALENCAR, José de. O Guarani. 3ª ed. Cotia: Ateliê, 2014.

AMARAL, Emília. "Apresentação". In: POMPEIA, Raul. O Ateneu. $2^{\mathrm{a}}$ ed. Cotia: Ateliê, 2005, pp. 9-36.

BARTHES, Roland. "A Retórica Antiga". In: COHEN, Jean et al. (orgs.). Pesquisas de Retórica. Tradução: Leda Pinto Mafra Iruzun. Petrópolis: Vozes, 1975, pp. 147-224.

BOSI, Alfredo. "O Ateneu, opacidade e destruição". In: Céu, Inferno: Ensaios de

Crítica Literária e Ideológica. São Paulo: Duas Cidades; Editora 34, 2003, pp. 51-86.

CAMPATO JÚNIOR, João Adalberto. A Confederação dos Tamoios: Gênese, Retórica e Ideologia da Epopeia no Segundo Reinado. Curitiba: CRV, 2014.

CARRODEGUAS, Celestino. La Sacramentalidad del Matrimonio: Doctrina de Tomás Sánchez, S. J. Madrid: Universidad Pontificia Comillas, 2003.

CHAUVIN, Jean Pierre. "O Verso Protocolar de Sebastião da Rocha Pita". XVII Encontro de Estudos Comparados de Literaturas de Língua Portuguesa. São Paulo: FFLCH/USP [ebook no prelo].

CICERÓN. El Orador. $4^{\mathrm{a}}$ reimp. Traducción: Eustaquio Sánchez Salor. Madrid: Alianza Editorial, 2010.

CUNHA, Manuela Carneiro da. Índios no Brasil: História, Direitos e Cidadania. São Paulo: Claro Enigma, 2012.

GOMES, Álvaro Cardoso; VECHI, Carlos Alberto. A Estética Romântica: textos doutrinários comentados. São Paulo: Atlas, 1992.

GRACIÁN, Baltasar. Arte de Ingenio, Tratado de la Agudeza. $2^{\mathrm{a}}$ ed. Madrid: Cátedra, 2010.

HANSEN, João Adolfo. "Instituição Retórica, Técnica Retórica, Discurso". Revista Matraga, v. 20, n. 33, 2013, pp. 11-46.

KOSELLECK, Reinhart. Futuro Passado: Contribuição à Semântica dos Tempos Históricos. $3^{a}$ reimp. Tradução: Wilma Patrícia Maas; Carlos Almeida Pereira. Rio de Janeiro: Contraponto; PUC-Rio, 2012.

MARTINS, Eduardo Vieira. "Apresentação". In: ALENCAR, José. O Guarani. $3^{a}$ ed. Cotia: Ateliê, 2014, pp. 11-42. 
MOSCA, Lineide do Lago Salvador. "Velhas e Novas Retóricas: convergências e desdobramentos". In: (Org.). Retóricas de ontem e de hoje. $3^{\mathrm{a}}$ ed. São Paulo: Humanitas, 2004, pp. 17-54.

MURPHY, James J. Rhetoric in the Middle Ages: A History of Rhetorical Theory from St. Augustine to the Renaissance. Berkeley: University of California Press, 1974.

PÉCORA, Alcir. Máquina de Gêneros. São Paulo: Edusp, 2001.

PEREIRA, Lúcia Miguel. "Raul Pompeia". In: . História da Literatura Brasileira: Prosa de Fiç̧ão (de 1870 a 1920). Belo Horizonte: Itatiaia; São Paulo: Edusp, 1988.

PLATÃO. Górgias ou A Oratória. Tradução: Jaime Bruna. São Paulo: Difel, 1970.

POMPEIA, Raul. O Ateneu. $2^{\text {a }}$ ed. Cotia: Ateliê, 2005.

RATIO Studiorum: Plan Raisonné et Institution des Études dans la Compagnie de Jésus. Traduction: Léone Albrieux; Dolorès Pralon-Julia. Paris: Belin, 1997.

REBOUL, Olivier. Introdução à Retórica. Tradução: Ivone Castilo Benedetti. São Paulo: Martins Fontes, 2000.

ROBRIEUX, Jean-Jacques. Éléments de Rhétorique et d'Argumentation. Paris: Dunod, 1993.

ROTERDÃ, Erasmo de. Diálogo Ciceroniano. Tradução: Elaine C. Sartorelli. São Paulo: Editora Unesp, 2013.

SILVA, José Bonifácio Andrada e. Apontamentos para a civilização dos índios bravos do Império do Brasil. Rio de Janeiro: Assembleia Geral Constituinte e Legislativa, 1823.

SOARES, Maria Nazaré Lins. Machado de Assis e a Análise da Expressão. Rio de Janeiro: INL, 1968.

SOUZA, Roberto Acízelo de. O Império da Eloquência. Rio de Janeiro: EdUERJ; EdUFF, 1999.

VERÍSSIMO, José. História da Literatura Brasileira. 4ª ed. Brasília: Editora da UnB, 1963.

WORDSWORTH, William. "Preface" to Lyrical Ballads (1800). Disponível em: <http://www.bartleby.com/39/36.html>. Acesso em: 16.9.2017. 


\title{
(Anti)Retórica em Gonçalves de Magalhães
}

\author{
Nunca poeta foi hipócrita (Junqueira Freire) $)^{292}$ \\ [...] esse livro fez-se por si, naturalmente, \\ sem esforço (Casimiro de Abreu) $)^{293}$ \\ Oh! terra de meu berço, \\ - oh pátria amada (Fagundes Varela) ${ }^{294}$
}

Resumo: O texto com que Gonçalves de Magalhães (1811 - 1882) apresenta Suspiros Poéticos e Saudades pretendia sintetizar premissas e valores da escola romântica. No entanto, embora o poeta se recusasse a seguir modelos da Antiguidade greco-latina e defendesse a honestidade com que compusera seus versos, tanto o "Prólogo" quanto os poemas do volume propiciam interpretação em chave inversa.

Palavras-Chave: Romantismo, Retórica, Gonçalves de Magalhães.

Abstract: In his presentation to Suspiros Poéticos e Saudades, Gonçalves de Magalhães (1811 1882 ), intends to synthesise some premises and values from romantic school. However, despite he refuses to follow Ancient greco-latin models and defended the honesty in your works, both "Prologue" and poems on the volume propitiate a different key interpretation.

Keywords: Romanticism, Rhetoric, Gonçalves de Magalhães.

\section{Arqueologia}

Publicado em Paris em 1836, quase simultaneamente com o primeiro tomo da Revista Niterói, o livro Suspiros Poéticos e Saudades reúne cinquenta e cinco poemas quarenta e três, na primeira parte (Suspiros Poéticos), e doze, na segunda (Saudades). 0 título dado ao volume não poderia ser mais decoroso: os versos são prenhes de interjeições e protestos de patriotismo daquele que se dizia poeta "peregrino".

A exemplo do que sucede a outras obras, hoje empregadas quase exclusivamente como meras balizas temporais e estéticas, os manuais de literatura brasileira costumam referendar o ensaio de Domingos José Gonçalves Magalhães, publicado no primeiro tomo de Niterói, como marco inaugural do "nosso" Romantismo. Em 1939, por ocasião de nova edição de Suspiros Poéticos e Saudades, Sérgio Buarque de Holanda assinalava que:

\footnotetext{
292 "Prólogo do Autor". In: Contradições Poéticas. Rio de Janeiro: Garnier, s/d., p. 4.

293 "Prólogo". In: As Primaveras. São Paulo: Martins Fontes, 2002, p. 6.

294 “Ao Brasil". In: O Estandarte Auriverde [Poesias Completas]. São Paulo: Edição Saraiva, 1956, p. 76.
} 
Os Suspiros Poéticos quiseram ser a um tempo o nosso prefácio de Cromwell e o grito do Ipiranga da poesia. O manifesto que no mesmo ano publicava Magalhães em sua revista Nitheroy (...) reflete em um só movimento as duas aspirações. O fato de surgirem, livro e revista, em Paris, tem, por outro lado, um aspecto simbólico. Daí por diante será a França, não Portugal, o país que vai ditar as regras e modas que seguirão os nossos homens de cultura (HOLANDA, 1986, p. 15).

Inspirado nos pareceres de Ferdinand Dennis e Almeida Garrett, sobre a literatura brasileira - ambos escritos em 1826 -, Gonçalves de Magalhães reafirmava a necessidade de os escritores da jovem nação substituírem a mitologia clássica pela mitologia cristã. Era imperativo escrever de nova maneira. A dicção "original" substituiria a "imitação" de modelos; a América, nova e emancipada, tomaria o lugar da Europa, antiga colonizadora; a "inspiração" tomaria o assento dos preceitos clássicos. De modo similar, o "Prólogo" à coletânea poderia ser considerado como uma espécie de síntese dos preceitos que orientavam a poesia do volume. Àquela altura, Gonçalves de Magalhães contava 25 anos e acabara de se formar em Medicina no Rio de Janeiro. Disposto a reforçar a ideia de que o seu livro inaugurasse um "novo" modo de conceber poesia, Gonçalves de Magalhães começa o texto de maneira originalíssima: o verbo "Lede" intitula o que poderia ser considerado uma "advertência" ao leitor ${ }^{295}$. Nas primeiras linhas, sugere analogias entre a arquitetura e a literatura. A "um pórtico ao Edifício" corresponderia "um prólogo ao Livro".

A aproximação entre as artes demonstra engenho (algo curioso, sendo o poeta tão adepto do "natural"). Como se reforçasse a similitude entre a fachada de um edifício e o papel do texto introdutório, recorre a palavras trissílabas e de sonoridade similar. Nada mal, para quem advogava a supremacia das paixões, e da suposta espontaneidade, sobre a razão, sob o influxo do cálculo. Ao final do primeiro parágrafo, Magalhães defende-se de eventuais leitores "preconceituosos", decerto embalados por "espíritos apoucados" (MAGALHÃES, 1986, p. 39). Princípio nem tão modesto, para quem pretendia afetar humildade e captar a benevolência alheia.

Em seguida, o poeta afirmaria que se tratava de "um Livro de Poesias escritas segundo as impressões dos lugares" (Idem, Ibidem, p. 39), sujeito, portanto, a oscilar

\footnotetext{
${ }^{295}$ Ao referir-se ao "Prólogo" de Suspiros Poéticos e Saudades, assim se pronunciou José Veríssimo: “Essas páginas anódinas, mal pensadas e mal escritas, nada têm do ardor dos iniciadores ou neófitos da nova escola fora daqui" (VERÍSSIMO, 1963. p. 144).
} 
quanto ao conteúdo, registro e forma, sujeito a diferentes tempos, ações e lugares. No segundo parágrafo, evoca alguns dos pilares da estética romântica: poder divino ("grandeza de Deus"), representação da morte ("ciprestes que espalham sua sombra sobre túmulos"), destino "da Pátria", espontaneidade e movimento ("um Peregrino"). Os poemas materializariam as impressões de quem transitara por entre diferentes países da Europa, cujos versos variavam segundo "as cenas da Natureza".

Mas como assegurar que o livro fosse aceito como prova de sua "boa-fé?". Era preciso reforçar a hipótese de que se tratava de "poesias da alma e do coração" e que, consequentemente, deveriam ser interpretadas pelo mesmo viés com que teriam sido compostas - supondo que o livro encontraria "eco" da "alma nestas folhas". Para isso, o poeta se lançava aos "pés" (Idem, Ibidem, p. 40) do público brasileiro, em potencial.

Após propor que o leitor ordinário se identificasse com as paixões representadas no livro, Gonçalves de Magalhães passa à segunda seção de seu "Prólogo", de maneira a induzir um novo método de análise: "Para bem se avaliar esta obra, três coisas releva notar: o fim, o gênero, e a forma" (Idem, Ibidem, p. 40). O discurso afeta didatismo, preocupação com o modo como a sua obra seria recebida e interpretada por aqui. A contradição é evidente: de um lado, impressionismo versificado; de outro, instruções com vistas a assegurar uma leitura que rumasse ao "absoluto".

O poeta adverte que sua obra tem acento emotivo, embora a representação das paixões pressuponha a aplicação de técnicas da poética. Afirma temer a Deus, embora passasse os dias a viajar, em autêntica vida mundana e "errante" em diversos países do exterior. Atesta a conotação patriótica dos versos, embora estivesse, havia anos, longe de sua "saudosa" terra.

Autointitulando-se patriótico e modernizador, embora situado no velho continente europeu, o poeta-andante afirma que o objetivo maior de Suspiros Poéticos e Saudades seria "elevar a Poesia à sublime fonte donde ela emana (...) indicando apenas no Brasil uma nova estrada aos futuros engenhos" (Idem, Ibidem, p. 41). Para isso, Magalhães tentara, "empunhando a lira da Razão, (...) vibrar as cordas eternas do Santo, do Justo e do Belo" (Idem, Ibidem, p. 41). A trinca de adjetivos não é fruto do acaso: Gonçalves de Magalhães introduz o critério de "santidade" entre as virtudes comuns ao gênero sublime - "justo" e "belo". 
Ao justapor "santidade", "justiça" e "beleza", sugeria a equiparação entre os valores preconizados pela fé católica àqueles que eram perseguidos não exclusivamente pelos poetas e filósofos, desde a antiguidade greco-latina. Ao acrescentar a qualidade do que seria "Santo" aos esteios da melhor tradição lírica, propõe o alinhamento de novos vértices a embalar o fazer poético.

Como evocara a temática religiosa, poucas linhas a frente tecerá ressalvas a Antônio Pereira de Sousa Caldas - embora o reconhecesse como "o primeiro dos nossos líricos". Contrariando as ideias de Rousseau e contestando a sua reverberação supostamente indevida, na poesia do sacerdote, lamenta que o poeta baiano "cantasse o homem selvagem de preferência ao homem civilizado", já que a civilização seria "obra de Deus" (Idem, Ibidem, p. 41).

Gonçalves Magalhães era natural do Rio de Janeiro. Representante de incerta elite da jovem pátria brasileira, o recém-diplomado passaria quatro anos na Europa, a afetar saudade da pátria. Talvez distante das ruas fétidas da Corte brasileira, encontrasse melhor ambiente para elucubrar modos eficazes de defender a expressão romântica. O discurso nega o modo como procede. É divertido supor que a poesia romântica fosse uma espécie de "eflúvio" da alma e que o poeta negasse a fonte do Monte Hélicon, embora bebesse na tradição greco-latina.

Em acordo com uma escala maior, rumo aos céus, Gonçalves de Magalhães elege o artista do verso como espécie moral de seu tempo: "O poeta sem religião, e sem moral, é como o veneno derramado na fonte" (Idem, Ibidem, p. 42). A aproximação entre moral, ética e estética avançam. Além de vértice da arte poética, "santidade" passa a ser sustentáculo não só dos versos bons, elevados em direção a Deus, mas condição do sujeito que tenciona aderir ao Romantismo.

Trilhados os objetivos da poesia romântica, o escritor sugere que "determinado e conhecido o fim, o gênero se apresenta[ria] naturalmente". O seu método, portanto, seria espontâneo e substituiria a ideia de "fazer uma obra segundo a Arte", em que "imitar era o meio indicado; fingida era a inspiração, e artificial o entusiasmo" (Idem, Ibidem, p. 43).

Em suma, o fazer poético substituiria o artifício dos clássicos pela sinceridade do versejador moderno. Ora, nada mais ultrapassado, feio e pequeno que supor "que com Homero emparelhavam; como se pudesse parecer belo quem achasse algum velho 
manto grego, e com ele se cobrisse! Antigos e safados ornamentos, de que todos se servem, a ninguém honram" (Idem, Ibidem, p. 43).

Corroborando a ideia de que seu livro primava pela espontaneidade do registro, o impulso de Deus e amor da Pátria, o poeta alega se tratar de obra feita ao sabor do aleatório, graças à despreocupação com a ordem dos versos e o método como foram construídos: "Quanto à forma, isto é, à construção, por assim dizer, material das estrofes, e de cada cântico em particular, nenhuma ordem seguimos; exprimindo as ideias como elas se apresentaram, para não destruir o acento da inspiração" (Idem, Ibidem, pp. 43-4).

Repare-se que a palavra "construção" aparece duas vezes no "Prólogo", o que parece contradizer o método supostamente "desordenado" do poeta. Tanto os seus versos revelam preocupação com a forma, quanto a sua disposição entre as duas partes do volume sugerem o contrário.

Ora, é justamente por enfileirar poemas datados em momentos diferentes e compostos em lugares variados, que Suspiros Poéticos e Saudades revela ter sido concebido em acordo com um arranjo pré-determinado que visava simular, no teor dos versos, mas também em sua distribuição "aleatória" no volume, maior efeito de "sinceridade": palavra-chave do projeto romântico.

Os artifícios, em nome do que chama de "natural", prosseguem. Se no primeiro parágrafo, Gonçalves de Magalhães comparara a poesia com a arquitetura, agora sugere sua analogia com a música, com vistas a driblar a monotonia dos sons e o ritmo simétrico dos versos: "não se compõe uma orquestra só com sons doces e flautados; cada paixão requer sua linguagem própria, seus sons imitativos, e períodos explicativos" (Idem, Ibidem, p. 44).

Escamoteando a persona de homem letrado, bem formado, jovem, rico e engenhoso, o poeta sugere que só contaria com duas espécies de leitores. Aqueles que o lessem "de boa-fé" poderiam "colher uma pérola no meio das ondas". Já aqueles que se aproximassem com "olhos de prisma" agiriam "como as serpentes", que "sabem converter em veneno até o néctar das flores" (Idem, Ibidem,p. 45).

O maniqueísmo participa do "Prólogo" e dos versos. Somente os leitores maliciosos, contaminados pela peçonha, seriam imunes a seus versos, inspirados pela 
bondade e honestidade, pois sua aproximação datada, calculista e minuciosa seria incompatível com uma poesia que emanava "do coração e da alma", como já vimos.

Para além do temor a Deus e a rejeição da cultura clássica, o autor afirma que a sua obra pagaria "um tributo à Pátria". Nas linhas finais, estabelece diálogo figurado com o livro, como se estivesse a traçar e prever o melhor caminho para a poesia que continha: "Tu vais, ó Livro, ao meio do turbilhão em que se debate nossa Pátria; onde a trombeta da mediocridade abala todos os ossos, e desperta todas as ambições; onde tudo está gelado, exceto o egoísmo" (Idem, Ibidem, p. 45).

Sim, o livro (personificação do próprio poeta) seguiria: "cheio de amor pela Pátria, de entusiasmo por tudo o que é grande, e de esperanças em Deus, e no futuro" (Idem, Ibidem, p. 46). Não será demasiado supor que o volume "peregrinaria" em meio a uma terra de medíocres - sina que o poeta procurara contornar sob o abrigo do velho continente.

\section{Arte}

A leitura atenta do "Prólogo" de Suspiros Poéticos e Saudades bastaria para mostrar que a simplicidade do poeta é fingida. Embora negasse seguir os modelos da tradição clássica ${ }^{296}$, Gonçalves de Magalhães lança mão de tópicas que remontavam a séculos de existência, já em seu tempo. É o que revela, por exemplo, o ato de se postar "aos pés" dos leitores - em que recorre a uma canônica fórmula de humildade, utilizada tanto pelo poeta, em 1836, quanto por Antônio Vieira, em meados do século XVII, ao enviar cartas a pessoas de posição superior.

Longe de ser fruto da espontaneidade, ou brotar das impressões aligeiradas do poeta "peregrino", o texto introdutório revelam artifício e acentuam o caráter programático do livro. Publicado no mesmo ano em que saíra o "Ensaio sobre a História da Literatura do Brasil", na Revista Niterói, esse segundo livro de Gonçalves de Magalhães integrava o projeto de filiação ao romantismo francês e português, que ele pudera conferir in loco, em companhia de Araújo Porto Alegre e Francisco de Sales

\footnotetext{
296 “Nas poesias iniciais de Magalhães nota-se frequentemente a influência dos árcades; nas seguintes, o abuso dos antigos modelos leva-o a acercar-se de um 'novo maravilhoso'. Nisso está o ponto de partida do seu romantismo" (HOLANDA, 1986, p. 20).
} 
Torres Homem. É deste último o comentário sobre Suspiros Poéticos e Saudades, quando da primeira edição do livro do amigo, em Paris:

Desde os princípios do século atual uma grande reação começou a abalar os antigos fundamentos do reino místico das musas. $O$ vago das lembranças do berço da civilização moderna, os sublimes pensamentos do Cristianismo, a simplicidade das cenas da natureza, que tão tocantes relações oferecem com as misérias do nosso coração, pareceram uma fonte de emoções mais delicadas e verdadeiras que os engenhosos sonhos da Antiguidade (TORRES HOMEM, 1986, p. 33). ${ }^{297}$

O artigo de Torres Homem reverberará no que dirão os críticos. A poesia de Magalhães é saudada como beata, natural, patriótica, nova e sincera; mas, embora o poeta negasse o emprego de artifícios e afirmasse desobedecer os modelos antigos, não despreza a forma. Por sinal, estrutura o "Prólogo" com múltiplos objetivos: sintetizar o teor do programa romântico, em curso; induzir a leitura do público; reforçar os votos com a religião oficial do Império; acentuar a ideologia patriótica, como maior alcance e penetração de uma literatura dita nacional. Como observou Maria Orlanda Pinassi:

Com a publicação da revista e do poema de Magalhães, começavam a provar o gosto da notoriedade entre figuras importantes da Corte, notoriedade que seria uma marca de seu papel intelectual durante quase todo o Império: Gonçalves Magalhães seria Visconde de Araguaia, Porto Alegre, Barão de Santo Ângelo e Torres Homem, Visconde de Inhomirim (PINASSI, 1998, pp. 18-19).

A tradição poética não só reverbera, mas também contagia os versos convencionais de Gonçalves de Magalhães. Comecemos pela tópica da vita brevis horaciana, facilmente detectável nos versos de "A Beleza":

A velhice, do mundo cansada,

A teu mando resiste somente;

Porém que te importa

A voz impotente,

Que se perde, sem ser escutada? (MAGALHÃES, 1986, p. 129)

\footnotetext{
297 “Esse juízo encomiástico, para quem leia hoje os Suspiros Poéticos e Saudades, mesmo para quem os lia no século passado [XIX], depois, talvez, de uns vinte anos de sua publicação, parece simplesmente o produto da amizade, da participação na mesma confraria literária" (BARROS, 1973, p. 77).
} 
Estruturado em quintetos, "A Beleza" contradiz a falta de projeto, anunciada pelo poeta no "Prólogo". Repare-se na alternância entre eneassílabos (no primeiro, segundo e quinto versos) e pentassílabos (no terceiro e quarto versos), o que confere um ritmo binário ao texto. Essa oscilação, na medida dos versos se repete nas dez estrofes do poema e parece reforçar o jogo de perguntas e respostas sugerido ao longo dos cinquenta versos:

Infeliz tenho sido até agora,

Que a meus olhos te mostras severa;

Nem gozo a ventura,

Que goza uma fera;

Entretanto ninguém mais te adora

(MAGALHÃES, 1986, p. 130).

Algo de similar se verifica em "A Tristeza", décimo quarto poema do livro:

Triste sou como o salgueiro

Solitário junto ao lago,

Que depois da tempestade

Mostra dos raios o estrago

(MAGALHÃES, 1986, p. 147).

Integralmente disposto em quartetos, todos os versos são heptassílabos e tentam comover o leitor mais duro. A quinta e última quadra evidencia o teor contraditório do que o eu lírico afirma. Embora afirme esperar pela morte, como "lenitivo", persiste em versejar, sem descuidar o ritmo dos versos, nem a alternância entre rimas, a justapor o primeiro com o terceiro e o segundo com o quarto versos:

Do mundo já nada espero, Nem sei por que inda vivo! Só a esperança da morte Me causa algum lenitivo (MAGALHÃES, 1986, p. 148).

Um dos temas-chave do livro é a saudade. Para abordar o motivo sob variada perspectiva, Gonçalves de Magalhães também presta homenagens aos velhos amigos, inclusive aqueles deixados na "pátria". É o que se lê no poema "XXV - Ao 
Meu llustre Mestre e Amigo / O Reverendíssimo Senhor / Fr. Francisco de MonteAlverne":

Eis-me em Roma! Da Pátria tão distante! Inda de vós conservo tal lembrança, Que às vezes se me antolha a imagem vossa;

A ela me dirijo, falo, escuto,

E cuido que ela me ouve, e me responde. Como de um tão bom mestre, tão amigo Poderá o discípulo esquecer-se? Quantas vezes aqui, nos sacros templos, Ouço santas palavras destes padres; Cuido ver-vos no púlpito elevado; Mas desconheço as vozes, e nem sinto Bater-me o coração dilacerado Da grave dor cristã; nem em transportes Subir minha alma ao céu como um eflúvio Da flor erguido; então saudoso exclamo: Quem me dera inda ouvir o grande Alverne! (MAGALHÃES, 1986, pp. 227-8).

Estruturado em decassílabos, o poema se aproxima formalmente de uma carta familiar, endereçada sob a forma de versos, ao frei - situado na "Pátria" comum, mas "tão distante". Repare-se: a opção pelas décimas não parece fruto de "impressões" ou palavras feitas ao sabor do acaso. Gonçalves de Magalhães parece aplicar as antigas lições da poética, que recomendavam adequar o tema ao gênero e às medidas do poema:

Embalde Roma invoco, e a musa empenho, Para um quadro traçar destes prodígios; Sem cessar uma voz me fala n'alma: Da louca pretensão que te alucina, Desiste, oh fantasia! não te é dado Achar uma linguagem tão facunda, Tão sublimes imagens com que pintes Dignamente esta imensa maravilha (MAGALHÃES, 1986, p. 228).

Embora o poeta reitere que os versos de Suspiros Poéticos e Saudades fossem inspirados nas "circunstâncias", a matéria de seus poemas invariavelmente combina memória e tradição, ainda que "Embalde Roma" invoque. O eu lírico sugere não ser capaz de empregar uma linguagem à altura de 
assunto tão elevado. Expediente semelhante será encontrado na segunda quadra do poema "XXX - No Álbum De Uma Veneziana", destinado a uma "bela virgem":

\author{
Quisera na minha lira \\ Cadenciar algum hino, \\ Com que louvasse os encantos \\ Desse teu rosto divino \\ (MAGALHÃES, 1986, p. 263).
}

De que trata o poema? Mais uma vez o eu lírico afirma que os seus parcos meios de expressão não lhe permitem "louvar os encantos" da homenageada, com "rosto divino". Duas estrofes mais e o poeta redige a estrofe nestes termos:

\author{
Ah! temo, temo, acredita, \\ Que a minha fúnebre lira, \\ Em vez de entoar um hino, \\ Só triste nênia desfira (Idem, Ibidem, p. 263).
}

Por acaso, a repetição do verbo "temer" guardaria relação com as imagens que se imprimiram tão fortemente na alma e peito do nosso "vate"? Mistério insondável, para além da discussão em torno da cota de verdade, porventura embutida no poema. De que elementos dispomos? O assunto é lírico e envolve os afetos do eu lírico por uma mulher. Talvez por esse motivo, Gonçalves de Magalhães redija o poema em quadras heptassílabas, como se pretendesse corroborar o vínculo entre tema, gênero e quantidade de sílabas métricas. Atentese, ainda, para as rimas finais: elas aproximam, em todas as estrofes, o segundo e o quarto versos.

\title{
Projeto
}

Nada menos "impressionista" ou "de boa-fé" que um projeto (calculado) e de cunho ambicioso, redigido mediante a confortável distância em relação ao país onde ele nascera e se formara. Não será demasiado lembrar que a Revista 
Niterói ${ }^{298}$ e o livro, ambos editados na França, circularam imediatamente no Brasil.

No ensaio de Gonçalves de Magalhães, lê-se o seguinte:

A poesia brasileira não é uma indígena civilizada; é uma grega vestida à francesa e à portuguesa e climatizada no Brasil; é uma virgem do Hélicon que, peregrinando pelo mundo, estragou seu manto, talhado pelas mãos de Homero, e sentada à sombra das palmeiras da América, se apraz ainda com as reminiscências da pátria, cuida ouvir o doce murmúrio da Castália, o trépido sussurro do London e do Ismeno, e toma por um rouxinol o sabiá que gorjeia entre os galhos da laranjeira (MAGALHÃES, 2014, p. 100).

Dessa forma, tanto o ensaio veiculado no periódico, em 1836, quanto o "Prólogo" e os poemas do livro serviriam como cartão de visitas em etapa posterior, quando da maior aproximação entre Gonçalves de Magalhães e Dom Pedro II. Na síntese de Lilia Schwarcz (1999, pp. 137-138):

[...] d. Pedro II, um jovem rei de 22 anos, vivia no "melhor dos mundos". Com a recente estabilidade política e financeira, obtida mediante a entrada do café brasileiro no mercado internacional, convertia-se no centro das atenções: o maestro da cena cultural, o pêndulo das decisões políticas. É esse o momento em que o imperador assumirá uma postura mais ativa junto ao Instituto Histórico e Geográfico Brasileiro e procurará formar uma geração de intelectuais e de artistas - segundo Freyre, tão jovens como ele -, que passarão a refletir sobre uma nacionalidade brasileira. É a época do indigenismo de fundo romântico, dos quadros grandiosos da Academia Imperial de Belas-Artes, dos exames no Colégio Pedro II. O imperador transformava-se aos poucos em um "monarca tropical".

Sob tal perspectiva, a criação do Instituto Histórico e Geográfico Brasileiro em 1838, pode ser considerada mais uma etapa do projeto de uma nação que caminhava tropegamente sobre o frágil assoalho da Independência e precisava reforçar a sua identidade no âmbito político e cultural. Lucia Maria Paschoal Guimarães relembra que:

298 "Carregando de culpa as empresas do colonizador português, baseadas sobretudo em formas de opressão estética e material, na revista Niterói é proposta uma ruptura com os valores coloniais, representados principalmente pelas normas clássicas e universalizantes que impediam a manifestação das particularidades brasileiras do espírito e da natureza. O passado, portanto, deveria ser corrigido mas, para isso, era mister abandonar a cultura da imitação e da generalização imposta pelos padrões portugueses" (PINASSI, 1998, p. 22). 
Em meio a tantas crises institucionais e às notícias de revoltas que agitavam o país, a Corte do Rio de Janeiro assistiu, no decorrer de 1838, à instalação de dois importantes centros da Memória Nacional. O primeiro, o Arquivo Público, criado em 2 de janeiro daquele ano, por ato do Ministro Bernardo Pereira de Vasconcellos. O segundo, tarde, em 21 de outubro, tratava-se de um empreendimento de caráter privado, que contava com o patrocínio da Sociedade Auxiliadora da Indústria Nacional. Sua fundação decorrera de uma proposição encaminhada ao Conselho Administrativo da Sociedade Auxiliadora, por iniciativa do Marechal Raymundo José da Cunha Matos e o Cônego Januário da Cunha Barbosa, que justificavam a nova instituição alegando o seu caráter pedagógico (GUIMARÃES, 2011, p. 33).

Como se sabe, nas décadas seguintes Dom Pedro II passaria a admirá-lo e defendê-lo, inclusive nos jornais da Corte, elegendo Domingos José Gonçalves Magalhães lídimo porta-voz da literatura nacionalista. Quase um brasão literário do Segundo Império. Sob essa ótica, o ruído suscitado pela controvérsia entre José de Alencar e Gonçalves de Magalhães, em torno da Confederação dos Tamoios, terá rendido eloquente murmuração na Corte enlameada do Rio de Janeiro. Mas, afora as disputas veiculadas em jornais e comentadas nos cafés, o saldo terá sido menor do que pretende certa crítica.

De certo modo, Dom Pedro II reeditava o mecenatismo de Sebastião José de Carvalho e Melo, durante o reinado de Dom José I, entre 1750 e 1777. No âmbito oficial, empenhado em dar maior representatividade aos poetas que orbitavam em torno do palácio, a proteção do imperador será levada às últimas consequências, na década de 1850. É sintomático que, no mesmo ano tenha sido criada a Revista Guanabara, sob a direção de Porto Alegre, Gonçalves Dias e Joaquim Manuel de Macedo. Em 1856 é publicado o célebre poemeto épico de temática indianista, $A$ Confederação dos Tamoios, pelo mesmo Gonçalves de Magalhães, agora sob o incentivo político, cultural e pecuniário do próprio imperador. ${ }^{299}$

\footnotetext{
299 'Retornando, de certa forma, ao modelo do 'bom selvagem' de Rousseau, Magalhães construía sob encomenda, o que deveria ser o maior épico nacional centrado na figura dos heróis indígenas, com seus atos de bravura e gestos de sacrifício. Tentando fundir a 'excentricidade romântica com a pesquisa histórica', esse autor acreditava ser possível superar as especificidades regionais para se chegar a um mito nacional de fundação" (SCHWARCZ, 1999, p. 206).
} 
Após intenso debate nos jornais da Corte ${ }^{300}$, em torno do épico de Magalhães, o fato é que, ao final da vida, tanto José de Alencar - desgostoso com o fato de ter sido preterido por Dom Pedro II ao posto no Senado -, quanto o protegido máximo do Imperador, Gonçalves de Magalhães, findariam seus dias sob o auspicioso manto da vida pública: um, recolhido em suas largas terras; outro, tão "patriótico" que trocara o novo mundo americano - cenário ideal para a nova poesia romântica - pela vetusta Europa.

Substancialmente, a trajetória de Gonçalves de Magalhães reforça a premissa de que a "sinceridade" continuava a ser afetação de homem letrado, sequioso por ampliar o seu leitorado e exercer maior influência junto aos círculos de poder. É que, em seu caso, a honestidade não passava de um projeto, capaz de lhe render o título de Visconde do Araguaia: autêntica mercê concedida pelo Império.

Porventura não seja demasiado lembrar que poesia é artifício. E o poeta não estava sozinho, no projeto romântico de vincular a arte à suposta honestidade e produzir efeito de verdade. A exemplo do que acontecia com seus conterrâneos, em Gonçalves de Magalhães "saudade" era, quase sempre, substantivo abstrato. E "suspiro" talvez nunca ultrapassasse o plano da interjeição.

\footnotetext{
300 Lê-se na segunda carta escrita por Alencar: "No retrato do herói, querendo dar uma ideia de sua ligeireza em atirar ao arco, o Sr. Magalhães ficou, para mim, aquém de J. Basílio da Gama, no seu poemeto do Uraguai. Há neste último mais simplicidade de forma, e ao mesmo tempo mais energia de pensamento" (ALENCAR, 2014, p. 435).
} 


\section{Referências}

ABREU, Casimiro José Marques de. As Primaveras. São Paulo: Martins Fontes, 2002.

ALENCAR, José de. "Carta Segunda". In: In: SOUZA, Roberto Acízelo de (org.). Historiografia da Literatura Brasileira: Textos Fundadores (1825 - 1888). Rio de Janeiro: Caetés, 2014, pp. 90-108, pp. 431-440.

BARROS, Roque Spencer Maciel de. A Significação Educativa do Romantismo Brasileiro: Gonçalves de Magalhães. São Paulo: Grijalbo; Edusp, 1973.

CUNHA, Cilaine Alves. "Ativismo neoclássico de Gonçalves Dias". Revista Língua e Literatura, n. 27, São Paulo: FFLCH-USP, 2003, pp. 225-243.

FREIRE, Luís José Junqueira. Obras Completas - Tomo II: Contradições Poéticas. $4^{\mathrm{a}}$ ed. Rio de Janeiro: Garnier, s/d.

GUIMARÃES, Lúcia Maria Paschoal. Debaixo da Imediata Proteção Imperial: Instituto Histórico e Geográfico Brasileiro (1838-1889). São Paulo: Annablume, 2011.

HOLANDA, Sérgio Buarque de. "Prefácio". In: GONÇALVES MAGALHÃES, Domingos José. Suspiros Poéticos e Saudades. $5^{\text {a }}$ ed. Brasília: Editora da UnB; INL, 1986, pp. 13-32.

MAGALHÃES, Domingos José Gonçalves. Suspiros Poéticos e Saudades. $5^{\mathrm{a}}$ ed. Brasília: Editora da UnB; INL, 1986.

" "Discurso sobre a História da Literatura do Brasil". In: SOUZA, Roberto Acízelo de (org.). Historiografia da Literatura Brasileira: Textos Fundadores (1825 - 1888). Rio de Janeiro: Caetés, 2014, pp. 90-108.

PINASSI, Maria Orlanda. Três Devotos, uma Fé, Nenhum Milagre. São Paulo: Editora UNESP, 1998.

SCHWARCZ, Lilia Moritz. As Barbas do Imperador: D. Pedro II, um Monarca nos Trópicos. $2^{\mathrm{a}}$ reimp. São Paulo: Companhia das Letras, 1999.

TORRES HOMEM, Francisco de Sales. "Artigo". In: GONÇALVES MAGALHÃES, Domingos José. Suspiros Poéticos e Saudades. 5a ed. Brasília: Editora da UnB; INL, 1986, pp. 33-37.

VARELA, Luís Nicolau Fagundes. Poesias Completas. São Paulo: Edição Saraiva, 1956.

VERÍSSIMO, José. História da Literatura Brasileira. 4ª ed. Brasília: Editora da UnB, 1963. 


\title{
Ut Musica Poesis: leitura do Requiem (1791), de Mozart ${ }^{301}$
}

\author{
Quid sum miser tunc dicturus? \\ (Joannes Chrysostomus Wolfgangus Theophilus Mozart) $^{302}$ \\ O harmony! thou tenderest nurse of pain, \\ If that thy note's sweet magic e'er can heal \\ Griefs which the patient spirit oft may feel, \\ Oh! let me listen to thy songs again \\ (William Lisle Bowles) $^{303}$
}

Em memória de Pierre Daniel Chauvin (1943-2013)

Resumo: Neste ensaio, propõe-se analisar partes do Requiem (1791) de Mozart (1756-1791), segundo a perspectiva da Musica Poetica. Levam-se em conta: o gênero da obra; o tema que ela aborda; as partes em que a matéria se divide; o modo como a performance das vozes e instrumentos correspondem decorosamente à dicção sacra e elevada, adequada ao estilo sublime. No diálogo entre as Letras e a Música, procura-se: apontar analogias entre palavras e notas; analisar a produção de metáforas; interpretar a conjugação entre melodia e harmonia.

Palavras-Chave: Musica Poetica, Retórica Musical, Letras, Requiem, Mozart.

Abstract: In this essay, we intend to analyze some parts of Mozart's Requiem (1791), from the perspective of Musica Poetica, considering the work genre; the theme it addresses; the parts in which the work it is divided; the voices and instruments performance in the way to decoratively correspond to the sacred and elevated diction, appropriate to the sublime style. In Letters and Music dialogue, we search for analogies between words and notes; analyze metaphors production. This interpretation also conjugates melody and harmony.

Keywords: Musica Poetica, Musical Rhetoric, Lettres, Requiem, Mozart.

\section{Ut Musica Poesis}

Seria a Música uma arte mimética? A discussão remonta aos filósofos do tempo de Sócrates. Em estudo recente, Leonardo Aldrovandi apontou a República e as Leis, de Platão, como obras fundamentais para apresentar uma parte da resposta. A seu ver, é necessário relativizar os conceitos de "originalidade" e "genialidade", que costumam ser atribuídos equivocadamente a compositores de outras eras - que superestimam os limites do artista, antes mesmo de sua emancipação como sujeito - o que só viria a

\footnotetext{
${ }^{301}$ Este ensaio retoma o capítulo final do projeto de pós-doutorado desenvolvido no programa de pósgraduação em Letras da Unifesp (Guarulhos), sob a supervisão de João Adolfo Hansen, em torno das letras e artes que circularam no mundo luso-brasileiro durante o século XVIII. Agradeço a Mônica Lucas, do Departamento de Música da ECA, a Cassiano Barros, pesquisador da UDESC, e a Felipe Faglioni, doutorando da ECA, USP, pela interlocução e pelas indicações bibliográficas.

302 "Tuba mirum" In: Requiem, 1986 [1791], p. 45.

${ }^{303}$ The Poetical Works, Vol. 1 (1815, p. 22).
} 
acontecer na passagem do Setecentos para o Oitocentos: momento em que a mimese

foi submetida à nova ordem do capital e à relação mais explícita da obra como "propriedade" intelectual, sujeita às noções incipientes de Direito Autoral ${ }^{304 .}$

[...] um pouco na contramão de certa ideologia sustentada em torno da criatividade individual ou da obra de arte vista como ser autônomo e purificado, independente dos processos de sua produção ou de sua recepção, veremos que a mimese ajuda a demonstrar que inclusive autores ou obras considerados singulares ou excepcionais sempre se valem de processos que emergem de uma zona que nos é comum (ALDROVANDI, 2019, p. XXI).

Para evitar impressionismos, que costumam desconsiderar o tempo ${ }^{305}$ e lugar $^{306}$ em que os letrados e artistas viveram, é preciso lembrar que o próprio entendimento da palavra "arte" variou sensivelmente, antes mesmo da rasoura romântica. Raymond Williams (2007, p. 61) lembrava que:

Antes de meados do Século 17, sem arte [artless] significava "inábil" ou "destituído de habilidade", e o sentido sobreviveu. Ocorreu, porém, um primeiro contraste regular entre arte e natureza, isto é, entre o produto da habilidade humana e o produto de alguma qualidade inerente. Sem arte adquiriu então, desde meados do Século 17, mas sobretudo a partir do final do Século 18, um sentido positivo para assinalar espontaneidade mesmo em "arte".

Natureza versus Artifício: fórmula que seria tomada em sentido bem diverso, com o advento do Romantismo, quando a relativa autonomização do artista elevou-o à condição de "gênio" (ou pária) social. Em meio à discussão sobre o caráter mimético das

\footnotetext{
${ }^{304}$ Numerosas discussões sobre os conceitos de "autoria" e "originalidade" foram sistematizadas por João Adolfo Hansen (1992, p. 11): "Desde o século XIX romântico, que generalizou a autoria como presença do indivíduo nas obras, a pertinência semântica da noção idealista assim produzida como 'criação' vem sendo questionada nas críticas à unificação substancializadora da sua particularidade histórica de produção e produto". De acordo com Joaci Pereira Furtado (1997, p. 28): “[...] o século XIX não se limitou a lançar a grife Mozart - isto é, a ideia de que tudo que traz sua assinatura é, por definição, um 'clássico'. TomouIhe também a biografia, com a qual o romantismo simpatizou de imediato, elegendo o artista como seu primeiro herói".

305 "Certamente as fisionomias musicais de Mozart e Haydn são bem conhecidas (...) A indumentária que a moda prescreve aos indivíduos de uma mesma geração impõe a seus usuários um modelo especial de gestos e uma determinada postura que são condicionados pelo corte das roupas. Da mesma maneira, a indumentária musical utilizada por uma época deixa sua marca na linguagem e, em sentido figurado, no gestual dessa música, assim como na atitude do compositor em relação ao material sonoro" (STRAVINSKY, 1996, p. 70).

${ }^{306}$ Mônica Lucas (2016, pp. 18-19) observa que "O ideal do vir bonus teve grande circulação durante os sécs. XVI, XVII e XVIII, reformulado no gênero literário conhecido como institutio aulica, ou escola de corte, que compreende os manuais devotados à descrição do príncipe ou do cortesão perfeitos. No mundo luterano, estes manuais foram utilizados no programa pedagógico dos ginásios. No séc. XVI, este ideal de perfeição passa também a ser discutido nas poéticas musicais. No âmbito italiano, a referencial obra de Gioseffo Zarlino, Institutione Harmoniche (1558), descreve da seguinte maneira o músico perfeito".
} 
artes - aqui, notadamente da música -, entre os séculos XVI e XVIII circularam tratados de Retórica e Poética Musical na Alemanha ${ }^{307}$, dentre os quais se destacam os de Joachim Burmeister, Johann Mattheson e Heinrich Christoph Koch.

Em 1513, Raffaele Brandolini (2001, p. 15) sugeria que "Sobretudo graças ao som da música, um exército poderia ser armar, entrar em formação e enfrentar o inimigo de cabeça erguida". Durante o Setecentos, apareceram manuais em vários países que aproximaram pintura, música e poesia, como evidenciam os Three Treatises, de James Harris (1765, p. 72), para quem: “A Poesia (assim como a Música) não tem outras fontes, além daqueles duas: Som e Movimento" ${ }^{308}$. Mônica Lucas assinala que, em 1764, Johann Mattheson:

[...] especifica alguns conhecimentos gerais necessários para o músico perfeito: conhecimento dos aspectos matemáticos dos temperamentos e da harmonia; conhecimento da língua grega e latina, suficientes para entender escritos sobre música, além da língua francesa e, sobretudo, italiana, línguas próprias do galant-homme. O mestre-de-capela deve também ser versado na melopoesia, ou seja, a poesia adequada à música (LUCAS, 2016, p. 119).

Evidentemente, a discussão não era matéria nova e os artistas ainda não levavam em conta a "originalidade", no sentido conferido à essa palavra, desde o Oitocentos. Fosse nos diálogos de Platão, fosse na Poética de Aristóteles, termos associados à sonoridade e disposição rítmica das palavras eram utilizados. Na Instituição Oratória, de Quintiliano, escrita no primeiro século da era cristã, há numerosas passagens que estabelecem analogias entre a oração (oratória), a poesia e a música e também ressaltavam aspectos comuns, tais como "tom", "harmonia" e "ritmo". Como dizia

\footnotetext{
307 "The rigorous application of rhetorical terminology and methodology to musical analysis and composition remained a predominantly German Baroque phenomenon. While rhetorical principles influenced musical composition in Italian, French. and English circles, only in Germany did this develop into an enthusiastic adoption and adaptation of rhetorical terminology, methods, and structures. This resulted in a veritable musical rhetoric, a 'local German dialect' which flourished particularly in the writings of Lutheran Kantors" (BARTEL, 1998, p. IX) - "A rigorosa aplicação da terminologia e metodologia retórica na análise e composição musical permaneceu sendo um fenômeno predominante no Barroco alemão. Enquanto os princípios retóricos influenciaram a composição musical nos círculos italianos, franceses e ingleses, apenas na Alemanha ele se converteu na entusiasmada adoção e adaptação da terminologia, dos métodos e das estruturas retóricas. Isso resultou numa autêntica retórica musical, um 'dialeto alemão local' que floresceu especialmente na escrita dos cantores luteranos".

308 "Poetry (like Music) has no other sources, than those two of Sound and Motion".
} 
Harris (1765, p. 96): “Existem sons que nos fazem alegres ou tristes; enérgicos ou doces; e isso acontece com quase toda afeição que sentimos" ${ }^{309}$.

A questão é que, por ignorar ou desprezar os tratados sobre música e poesia que circularam entre os séculos XVII e XVIII, nem sempre os manuais sobre a história da Música levaram tais preceptivas em maior e melhor consideração. Por exemplo, na versão inglesa da Enciclopédia Larousse, editada por Geoffrey Hindley em 1971, continuamos a encontrar a tradicional (e questionável) periodização da História da Música (Barroco, Classicismo, Romantismo...), em que Bach condensaria o assim chamado Barroco; Mozart seria o paradigma clássico; e Beethoven, o representante maior da transição para o Romantismo (HINDLEY, 1986). Via de regra, quanto mais suscinto o manual, mais evidentes e limitadores são os rótulos e generalizações etiquetados aos compositores, obras e "movimentos". Outro exemplo: em Uma Breve História da Música, lê-se que a arte musical poderia ser agrupada em datas estanques, que não admitiriam a sobreposição de gêneros, estilos ${ }^{310}$ e temas em um mesmo tempo:

Música medieval - até cerca de 1450

Música renascentista $-1450-1600$

Música barroca - $1600-1750$

Música clássica - 1750-1810

Romantismo do século XIX - 1810-1910

Música do século XX

(BENNETT, 1986, p. 11).

Seria importante flexibilizar as estreitas margens temporais e "estéticas", reproduzidas na maioria dos manuais sobre História da Música. Para isso, discute algumas noções de Retórica Musical, na tentativa de aproximar Música e Poesia, e examina, em particular, o Requiem de Wolfgang Amadeus Mozart (1756-1791), para além das características que reduziriam sua obra e denotariam seu pertencimento ao chamado Classicismo. Joaci Pereira Furtado (1997, pp. 27-28) observa, com acuidade, que:

Contemporâneo e entusiasta - mesmo que moderado - do radicalismo burguês, com a era pós-1789 o musicista foi enobrecido com o anfíbio título de "clássico". Sua morte, descrita de modo tão dramático por [Milos] Forman, bem que lhe

\footnotetext{
309 "There are Sounds to make us' chearful, or sad; martial, or tender; and so of almost every other Affection, which we feel".

${ }^{310}$ Para Joachim Burmeister (2017, p. 198), havia "[...] quatro estilos: 1. O humilde; 2. O grandioso; 3. O médio; 4 . O misto. $\mathrm{O}$ estilo é humilde quanto os intervalos se sucedem em degraus mais próximos".
} 
pode autorizar poses de mártir, já deslocado num mundo que desejava transformado de acordo com o que naquele final de século era aspiração de muitos. Entretanto, o músico cujo cadáver se perdeu no cemitério vienense de São Marcos estranharia tanta veneração, se se considerarem, por exemplo, os dados documentais. Em sua correspondência, por exemplo, ele não demonstra nenhuma preocupação em nutrir fama de gênio. Mozart foi antes de tudo um típico compositor vivendo sob o Antigo Regime. Como tal, teve de perseguir encomendas e empregos mal remunerados e depara-se com frequentes humilhações.

Dentre os conceitos abordados na análise e interpretação do réquiem, consideram-se aspectos relacionados à melodia, harmonia, disposição de vozes e instrumentos, características timbrais etc. Também se considera o emprego de lugarescomuns e metáforas, uma vez que, a exemplo das Letras, da Pintura, da Escultura e da Arquitetura, a Música setecentista se orientava por preceptivas retórico-poéticas e consistia na imitação de modelos. O estudo de Leonard Ratner (1980, p. 9) é fundamental, nessa abordagem:

Devido ao contato com os cultos, a poesia, o drama, os entretenimentos, a dança, as cerimônias, os militares, a caça e a vida das classes sociais inferiores, no início do século XVIII a música desenvolveu um repertório de figuras características, que formou um rico legado para os compositores. Algumas dessas figuras se associavam a sentimentos e afetos; outras tinham sabor pitoresco. Aqui, elas foram designadas como tópicas-assuntos do discurso musical. Tópicas aparecem como peças plenamente realizadas, ou seja, tipos; ou como figuras e progressões em uma peça, ou seja, estilos. A distinção entre tipos e estilos é flexível: minuetos e marchas representam tipos completos de composição; mas também fornecem estilos para outras peças musicais. ${ }^{311}$

Como se disse, os compositores, assim como os poetas e artistas daquele tempo, emulavam músicos precedentes e transcreviam sons, pausas e silêncios para as partituras, segundo a concepção de que a palavra estava para a nota assim como o verso, para o fraseado 312 - como apontou Kofi Agawu (2009, pp. 15-16):

\footnotetext{
311 "From its contacts with worship, poetry, drama, entertainment, dance, ceremony, the military, the hunt, and the life of the lower classes, music in the early 18th century developed a thesaurus of characteristic figures, which formed a rich legacy for classic composers. Some of these figures were associated with various feelings and affections; others had a picturesque flavor. They are designated here as topics-subjects for musical discourse. Topics appear as fully worked-out pieces, i.e., types, or as figures and progressions within a piece, i.e., styles. The distinction between types and styles is flexible; minuets and marches represent complete types of composition, but they also furnish styles for other pieces". 312 "The idea that music and language are closely affiliated possesses considerable historical and geocultural depth. John Neubauer reminds us that the ancient Greeks, for example, designated music and language by a single term, musiké. Plato advocated a 'word-dominated music' over a 'mathematical music', and Saint Augustine challenged that particular prioritization while enunciating the benefits of wellchosen words for the music that accompanies worship. In the seventeenth and eighteenth centuries, links
} 
A ideia de que música e linguagem estão intimamente associadas tem raízes históricas e geoculturais. John Neubauer nos lembra que os gregos antigos, por exemplo, designaram música e linguagem com um mesmo termo, musiké. Platão advogava o domínio da "música-palavra" sobre a "música matemática", e Santo Agostinho contestava os benefícios dessa priorização em particular, durante a enunciação de palavras bem-escolhidas para a música que acompanha o culto. Durante os séculos XVII e XVIII, ligações entre música e retórica frequentemente foram reconhecidas e ocasionalmente teorizadas, sendo a retórica musical "o esforço mais concentrado em aplicar princípios verbais à música, na história".

\section{A analogia "música como poesia" comparece em muitos versos compostos entre}

o século XVII e XIX. De acordo com Mônica Lucas (2013, p. 14):

[Johann Nikolaus] Forkel entende o vínculo entre música e linguagem segundo dois aspectos diversos, porém relacionados. $O$ primeiro se concentra no aspecto histórico, estabelecendo para ambas as artes uma origem comum, que permitiria a transposição completa das premissas da linguagem verbal para o âmbito musical. Forkel afirma que a música teria evoluído desde um estágio primitivo, em que seu conteúdo seria em grande parte indeterminado, até a constituição de uma linguagem perfeitamente análoga à linguagem verbal, em que as emoções e suas modificações poderiam ser expressas com grande precisão. Isso permite a ele estabelecer uma segunda abordagem para a ligação entre música e linguagem ${ }^{313}$, segundo seu aspecto sistemático. Forkel parece ser o primeiro autor a utilizar o termo gramática para se referir ao conjunto de prescrições e regras que determinam o uso correto da linguagem musical. Ele trata ainda da retórica musical, seguindo o aspecto sistemático parcialmente elaborado por autores anteriores a ele.

Por sua vez, Cassiano de Almeida Barros $(2018$, p. 6) considera que:

Partindo da analogia entre música e linguagem, em conformidade a mecanismos e categorias do discurso verbal e da lógica, [Heinrich Christoph] Koch sistematiza uma fraseologia musical, constituindo ferramentas que viabilizam uma espécie de racionalização do pensamento musical. De acordo com essa sistematização, a analogia entre música e linguagem se estende para a relação entre linguagem e pensamento: se a linguagem verbal condiciona o pensamento verbal ao mesmo tempo em que é condicionada por ele, a linguagem musical condiciona e é condicionada pelo pensamento musical. Nesses termos, a relevância da

between music and rhetoric were frequently acknowledged and occasionally theorized, musical rhetoric being 'the most concerted effort in history to apply verbal principles to music'." (AGAWU, 2009, pp. 1516).

${ }^{313}$ Em sua pesquisa de pós-doutorado, Mônica Lucas (2008, p. 25) demonstrou que: “A concepção musical luterana centra-se na representação de palavras do texto. Para autores reformados, a palavra isolada é entendida como a matéria da inventio; a fantasia do compositor deve girar em torno de palavras do texto que possuam conteúdo afetivo e imagético. Andreas Herbst, em seu Musica Poetica (1643), oferece quatro categorias de palavras musicalmente representáveis: verbos que exprimem afecção, verbos locomotivos, advérbios e as idades do homem ou seus atributos.40 No pensamento luterano, certos procedimentos musicais não só representam, mas ainda explicam a palavra, evidenciando seu sentido oculto, geralmente fundamentado nos dogmas da doutrina". 
fraseologia para a produção musical consolida-se a partir de sua sistematização, proposta como a sistematização do próprio pensamento musical em si.

De acordo com Leonard Ratner (1980, p. 25):

Tendo em vista a abundância de tópicas disponíveis, os compositores do século XVIII puderam dar maior passo e tornar sua música francamente pictórica. $\mathrm{O}$ pitoresco e a pintura com palavras representam esforços para imitar ou representar ideias específicas da poesia e de outros gêneros literários. 0 pitoresco, associado em geral com a música instrumental, transmite a ideia de uma ação ou cena. A pintura com palavras corresponde à palavra da oração, em um texto como figuração musical. Ambos os procedimentos foram honrados, durante séculos, em madrigais, composições francesas descritivas para cravo, peças de batalha etc. ${ }^{314}$

Nessa acepção, a partitura musical, assim como a notação do poema, resultaria da combinação decorosa de melodia e harmonia ${ }^{315}$ (conveniente e proporcional), conforme o gênero (lírico, épico, dramático), adequada ao tema (pastoral, amoroso, fúnebre), à forma musical (réquiem, sinfonia, balada, rondó, minueto, valsa, noturno etc.) e ao estilo ${ }^{316}$ (gravis, mediocris, humilis) e à extensão. Como se sabe, as relações entre música e poesia remontam à Grécia Arcaica, oito, nove séculos antes da Era Cristã. Quase mil anos depois, no primeiro livro da Instituição Oratória, Quintiliano ressalta a

314 "Given the wealth of available topics, 18th-century composers at times could easily take a further step and become frankly pictorial in their music. Pictorialism and word-painting in music represent efforts to imitate or symbolize specific ideas from poetry or other types of literature. Pictorialism, generally associated with instrumental music, conveys some idea of an action or scene. Word-painting is the matching of a word of phrase in a text to a musical figure. Both procedures had been honored for centuries in madrigals, descriptive French clavecin music, battle pieces, etc.".

315 "A harmonia é um poema musical construído a partir de melodias de variadas vozes, ligadas entre si" (BURMEISTER, 2017, p. 103). Convém sinalizar para o emprego da melodia e da harmonia na poesia lusobrasileira, para relembrar a mão dupla que há entre música e poesia. "O poeta seiscentista tendia a desenvolver a harmonia, isto é, o efeito da simultaneidade de recursos semânticos, sonoros e sintáticos. O árcade prefere a melodia, a correnteza frasal da linha" (MARQUES, 2017, p. 61).

316 "The fantasia style is recognized by one or more of the following features-elaborate figuration, shifting harmonies, chromatic conjunct bass lines, sudden contrasts, full textures or disembodied melodic figuresin short, a sense of improvisation and loose structural links between figures and phrases. (...) In 18thcentury opera, the fantasia style is used to evoke the supernatural the ombra, representing ghosts, gods, moral values, punishments-and to bring forth feelings of awe and terror. Mozart incorporates elements of the church style - alla breve, stile legato - in the introduction to his overture to Don Giovanni, K. 527, 1787 , and later recalls this music in the duel, Act I, and the "supper" scene, Act II. Beethoven may well have had the ombra in mind in the introduction to his Symphony No. 4 in Bb major, Op. 60, 1806" (RATNER, 1980, p. 24) - "O estilo fantasia é reconhecido por um ou mais elementos da figuração seguinte: harmonias cambiantes, linhas de baixo cromáticas, contrastes repentinos, texturas cheias ou figuras melódicas flébeis, senso de improviso e estruturas soltas a ligar figuras e frases. (...) Na ópera setecentista, o estilo fantasia foi utilizado para evocar o sobrenatural, a sombra, a representar fantasmas, deuses, valores morais, o castigo e estimular sentimentos de temor e terror. Mozart incorporou elementos do estilo sagrado - alla breve, stile legato - na 'Introdução' à 4a Sinfonia, em Si bemol maior, Op. 60, 1806". 
importância de estudar variados saberes para se aprofundar no estudo da Oratória, com vistas ao entendimento e produção de discursos com fins persuasórios ${ }^{317}$ :

Também não é suficiente ter lido os poetas; é necessário estudar a fundo todas as espécies de escritores, não tendo em vista o conteúdo, mas as expressões, que frequentemente adquirem legitimidade pelos autores. Tanto não pode a gramática ser perfeita se a música, que é preciso ensinar-lhe sobre os metros e os ritmos; se desconhecer o movimento dos astros não entenderá os poetas, que - para deixar de lado outros pontos - tantas vezes usam o nascer e o ocaso dos astros para a determinação dos tempos; também não pode desconhecer a filosofia, tanto por causa de referências muito numerosas, em quase todos os poemas, tiradas das mais abstratas questões naturais, como os de Empédocles entre os gregos, os de Varrão e de Lucrécio entre os latinos que legaram em versos os preceitos da sabedoria (Quintiliano, 2015, pp. 77 e 79).

\section{Invenção, Disposição, Performance}

O Requiem de Wolfgang Amadeus Mozart (1756-1791) resultou da encomenda de uma peça musical ao compositor austríaco no ano de sua morte. Inacabada, a obra teria sido revista e concluída por um ou mais colaboradores, especialmente Franz Xaver Süssmayr (1766-1803). Praticamente um século após a morte de Mozart, Henri de Curzon (1888) traduziu e editou centenas de cartas do compositor. Cem anos depois, Robbins Landon reuniu relatos testemunhados pela esposa de Amadeus, Constanze. Apoiado por vasta documentação e biografias, o investigador reforçou a hipótese de que o compositor teria cobrado cinquenta ou cem ducados pela composição do Requiem, estimando em "[...] cerca de quatro semanas" (LANDON, 1990, p. 77), o prazo para entregar a partitura manuscrita. ${ }^{318}$

\footnotetext{
${ }^{317}$ Quintiliano tornou a ser considerado em relação às Letras e à Música, durante o século XVIII, período em que, "To be persuasive, both linguistic and musical rhetoric had first to establish coherence and then promote eloquence. This was done by defining the various components of discourse, indicating their functions, and demonstrating ways in which they might be persuasively arranged. Many 18th-century theorists looked upon phrase structure, chord progression, rhythmic scansion, melodic construction, texture, and performance as the rhetoric of music" (RATNER, 1980, p. 31) - "Para serem persuasivas, primeiramente, a retórica verbal e a musical precisavam estabelecer coerência entre si e promover a eloquência. Esse caminho foi logrado, definindo-se os vários componentes do discurso, indicando-se suas funções e demonstrando-se os modos como eles precisavam ser arranjados persuasoriamente. Diversos teóricos do século XVIII observaram a estrutura frasal, a progressão dos acordes, a divisão rítmica, a construção da melodia, a tessitura e a performance como [elementos da] retórica musical".

318 "No dia 14 de fevereiro de 1791 a morte arrancou do senhor Conde van Walsegg sua querida esposa, na flor da vida (ela ainda não completara vinte e um anos). Ele quis erigir um memorial duplo para ela e para tanto teve uma excelente ideia: conseguiu através de seu representante comercial, o Senhor Dr. Johann Sortchan, Advogado da Corte e do Judiciário, em Viena, que um dos melhores escultores de Viena [Johann Martin Fischer, 1740-1822] moldasse um epitáfio, e que Mozart compusesse um Réquiem para o
} 
Afora o dado anedótico, há que se levar em conta que a autoria de uma música ou poema, no final do século XVIII, não tinha a mesma relevância, nem atribuía o mesmo prestígio ao músico, como viria a acontecer no Romantismo - quando o artista deixou a condição de vassalo do reino, submetido às leis do Estado, e passou à condição de indivíduo, a disputar pelo mercado da arte, com seus produtos (Hansen, 1992). Norbert Elias (1995, pp. 17-18) advertia que:

Tanto na Alemanha como na França[,] as pessoas que trabalhavam neste campo [musical] ainda eram fortemente dependentes do favor, do patronato e, portanto, do gosto da corte e dos círculos aristocráticos (e do patriciado burguês urbano, que seguia seu exemplo). Na verdade, mesmo na geração de Mozart, um músico que desejasse ser socialmente reconhecido como artista sério e, ao mesmo tempo, quisesse manter a si e a sua família, tinha de conseguir posto na rede das instituições da corte ou em suas ramificações.

O músico da corte deixou de frequentar espaços mais restritos e gradativamente se integrou à lógica burguesa, que substituiu os modelos pela originalidade dos produtos, a disputar espaço no mercado de bens culturais. De todo modo, talvez se possa afirmar que o compositor austríaco estivesse acima da elevada média dos músicos de seu tempo. Porém, a visão que temos de Wolfgang Amadeus Mozart - gênio injustiçado, morto na miséria - começou a ser forjada no mesmo século XIX, quando passou a se cristalizar uma imagem idealizada que superestimava o compositor inclusive no Brasil, ainda Estado português, durante a regência de Dom José I.

No quesito extrapolação, o filme Amadeus, de 1984, baseado na peça de Peter Shaffer, é uma amostra eloquente dessa caricatura, pasteurizada e mitificadora, do músico vienense. Ao superestimá-lo, foi preciso transformar Antonio Salieri (1750-1825) em compositor inepto, padre invejoso e tipo criminoso. "As injustiças vitimaram até a pobre Constanze Mozart [1762-1842], tida como esposa imbecil e viúva oportunista"

qual ele (o conde), como sempre, reservou exclusivo direito de posse" (LANDON, 1990, p. 79). Em Opus Ultimum, Daniel Lesson (2004, p. 5) argumenta que: "The romantic imagination is overwhelmingly captured by the essence of the tragedy found in the story of Mozart's composition of the Requiem. Evidence of this in the English-speaking world may be found in the many fiction stories published by periodicals during the nineteenth and early twentieth centuries, almost all of which have the same common Requiem-related theme: the central character dies with his final and most glorious composition unfinished" - "A imaginação romântica foi absolutamente capturada pela essência da tragédia relacionada à história sobre a composição do Requiem de Mozart. Uma evidência disso, no mundo anglófono, pode ser encontrada em diversas histórias de fiç̧ão publicadas em periódicos do século XIX e início do XX, quase todas recorrendo ao mesmo lugar-comum: o protagonista morria ao final, deixando inacabada sua gloriosa composição". 
(FURTADO, 1997, p. 29). Seria menos impreciso e mais produtivo analisar e interpretar algumas partes do Requiem à luz da retórica musical e do que se convencionou chamar Musica Poetica, na Europa, entre os séculos XVI e XVIII. Digamos algo sobre o tema (inventio) e a configuração da obra. Quanto ao gênero, o réquiem se relaciona à matéria sacra $^{319}$ - peça fúnebre que celebra uma divindade ou é produzida em memória de alguém que faleceu. $O$ gênero poderia estar relacionado ao propósito moralizante da igreja, pelo menos desde o século $X \mathrm{VI}{ }^{320}$.

Para ser decoroso ao compor um réquiem, o músico recorre a hinos (missais), leva em conta matérias sublimes ${ }^{321}$ (representação da morte ${ }^{322}$, chamado dos anjos, paixões inspiradas por Deus, luz da Graça ${ }^{323}$, paz eterna etc.). De acordo com Mônica Lucas $(2008$, p. 32):

319 Os biógrafos de Mozart sugerem que ele teria compartilhado com a esposa grande interesse em compor uma peça do gênero réquiem (Cf. LANDON, 1990, p. 75 e ss). De acordo com Mônica Lucas (2013, p. 18): “Para Forkel, matérias distintas estabelecem três estilos principais de escrita: o estilo sacro, que se relaciona com afetos elevados, nobres e devotos, o estilo de câmara, utilizado para o deleite de um público seleto em ambientes privados e o estilo teatral, utilizado para a expressão de sentimentos morais. Forkel descarta a divisão retórica tradicional que divide os estilos em alto, médio e baixo, segundo a qualidade do afeto representado. Ele a substitui por uma distinção segundo as emoções básicas da alegria/serenidade, melancolia e da ira".

320 Cassiano Barros $(2020$, p. 18) observa que "Lutero atribuiu um lugar de destaque à música em sua proposta de reforma religiosa. Reconhecida como instrumento próprio da ação do Espírito Santo, conforme relatos das Escrituras - como por exemplo em II Reis 3:15 - a música ocupou o lugar seguinte ao da Palavra de Deus, a principal, se não a única fonte de conhecimento Dele. De fato, Lutero reconhecia na música uma origem divina, observando sua presença na natureza como manifestação da 'voz' das coisas, e considerando que 'desde o começo do mundo ela foi infundida e implantada em todas as criaturas, individualmente e coletivamente. Pois nada existe sem som, sem número sonoro'."

${ }^{321}$ Lê-se no Tratado do Sublime, de Longino: "[...] ]a nossa alma naturalmente se eleva em certo modo com o Sublime verdadeiro" (OLIVEIRA, 1984, p. 56). Lê-se em Lectures on Rhetoric and Belles Lettres, de Hugh Blair, publicado em 1783 (2005, p. 26): "It [sublime] produces a sort of internal elevation and expansion; it raises the mind much above its ordinary state; and fills it with a degree of wonder and astonishment, which it cannot well express" > "O sublime produz uma espécie de elevação expansão espiritual; ele eleva a mente muito acima do senso ordinário e a preenche com um grau de maravilhamento e surpresa que não pode ser facilmente expresso".

${ }^{322} \mathrm{Com}$ "[...] o desenvolvimento da ópera no final do Renascimento, as obras musicais passaram a ter um caráter narrativo mais definido e, com a caracterização maior dos temas, as questões das imagens sonoras se estabeleceram, consolidando-se muitas vezes por meio da utilização estereotipada de certos recursos musicais. Um exemplo disso é o modo como os compositores começaram a tratar a representação do profano e do celestial, da morte e da ressurreição no contexto musical" (CAVINI, 2005, p. 216).

323 “[...] por um lado, 'graça' deveria ser uma dimensão que permeia toda a teologia, na medida em que ela trata do Deus capaz de relação e disposto à relação, cuja graciosa autodoação é inaugurada com a criação e consumada escatologicamente. Por outro lado, é preciso tratar a graça como encontro entre Deus e ser humano no drama da sua história de amor, antes de se falar das múltiplas formas de veiculação 'sacramental' da vontade de graça divina na Igreja e no mundo" (HILBERATH, 2001, p. 14). De acordo com João Adolfo Hansen (2006, p. 105): "Como "centelha da consciência", a sindérese é a presença da Lei natural na mente, aconselhando o bem e vituperando o mal. No XVII, a noção relaciona-se com a doutrina do juízo e da prudência, fundamentando a solércia ou a sagacidade que especifica o tipo do discreto; é também a sindérese que evidencia, na forma exterior do decoro estilístico, as operações éticas do juízo, 
[...] as artes, no sistema das artes liberales, têm como finalidade a Virtude ${ }^{324}$, no sentido ético-retórico do século XVII, e a divisão entre elas, fundamentada na qualidade da representação, se dá entre as artes que representam o número (quadrivium) e as que representam a palavra (trivium). Embora em outras artes, esta divisão tenha perdido a validade já no século XIII, na música, no mundo luterano, ela é normativa até o século XVIII. ${ }^{325}$

As composições relacionadas a esse gênero ${ }^{326}$ costumam ser concebidas em escalas, fraseados e harmonias de tonalidade menor ${ }^{327}$, prevendo-se que sua execução obedeça a andamentos lentos (Largo, Adagio), alternados com moderados (Andante) e moderadamente velozes (Allegro, Cantabile). No Requiem de Mozart, as melodias representam vozes ${ }^{328}$ performadas solitária (Solo) ou coletivamente (Tutti), com maior (Forte, Fortíssimo) ou menor intensidade (Piano, Pianíssimo). Ao analisar a Sinfonia de Praga, Leonard Ratner (1980, p. 27) sustentou que:

Mozart foi o grande mestre em combinar e coordenar tópicas, frequentemente nos espaços mais reduzidos, e com brilhante contraste. O movimento Allegro do primeiro movimento da Sinfonia de Praga K 504, 1786, é um panorama de tópicas, antigas e novas, em que a mudança do tema ocorre a pequenos intervalos. A "Introdução" se relaciona com o Allegro pelos meios mais sutis.

como circumscriptio (cf. Santo Tomás de Aquino, Summa Theologica, 2o, I, 94, art. I, 2; 1a part., 79, art .XII)".

${ }^{324}$ Cassiano Barros (2018, pp. 4-5) observa que, de modo similar, que "Koch compreendia que o fim da arte musical, assim como de todas as demais belas artes, consistia na edificação moral do homem. Para alcançar este fim, as obras musicais deviam estar conformadas para a persuasão, de modo que fossem obtidas a adesão para as virtudes e a aversão aos vícios. Nesse sentido, as 'formas musicais', como designadas por Koch, não eram entendidas como estruturas pré-moldadas ou moldes para serem preenchidos por matéria amorfa, mas como gêneros discursivos, modos de representação do pensamento que conformam a matéria tratada de acordo com suas características e condições de recepção".

325 Kevin Barry (1987, p. 143) mostrou que as composições de temática e gênero sacro foram muito cultivadas ao final do Setecentos: "Uma equação contemporânea entre música e idealismo era religiosa. O próprio [poeta William Lisle] Bowles, em um panfleto em defesa dos oratórios, arguia que 'de todas as artes do homem, a música era a única associada, em nossa mente, às alegrias puras e felicidade do céu' . Para outro clérigo escritor, um adágio de Mozart revelava os mesmos sentimentos latentes de espécie divina".

${ }^{326}$ A discussão em torno dos gêneros musicais é relevante, também, porque pressupõe e assinala critérios específicos, relacionados à matéria e ao estilo das composições. Pedro Marques $(2017$, p. 60) ressalta as correspondências entre música e poesia, no século XVIII: "Soneto, cançoneta, lira, rondó ou madrigal, conformam raciocínios e cenários límpidos, numa língua metrificada que, limada na escrita, flui musicalidade na locução oral".

327 "[...] as expressões formadas a partir dos tons individuais das escalas se conformam entre si para a caracterização dos nossos sentimentos, assim como as partes da linguagem se conformam para a caracterização das diversas relações de um objeto ou pensamento. Portanto, temos tons principais, característicos e de ligação, tão variados quanto as emoções com todas as suas relações e maneiras de encaixe e que ser vem para a sua expressão" (FORKEL Apud LUCAS, 2013, p. 15).

328 "A voz é um corpo melódico formado e constituído pela acumulação de sons em que os movimentos ascendentes e descendentes são concebidos em vista da composição musical cantada" (BURMEISTER, 2017, p. 93). 
Inicialmente, é difícil perceber a mudança de tempo entre o Adagio e o Allegro; a sincopação em dois níveis - a quarta e oitava notas dos primeiros violinos contra a alla zoppa da quarta e meias-notas das cordas mais graves - obnubilam o ritmo; a melodia da canção é ocultada pelos instrumentos graves enquanto a harmonia oscila no tom de Sol, graças ao Dó sustenido. Tudo isso concede maior brilho às fanfarras, que concluem o primeiro período do Allegro, imprimindo um perfil afiado ao tom, à melodia e ao ritmo. ${ }^{329}$

Na forma como o conhecemos (transcrito), o Requiem de Mozart (1986 e 2018) divide-se em doze seções. O primeiro aspecto a observar reside no fato de que a partitura revela simetrias em sua distribuição (dispositio): as duas partes mais longas são justamente a primeira ("Introitus") e a última ("Agnus Dei"), com a mesma quantidade de páginas (MOZART, 2018). As duas mais breves são a terceira ("Tuba Mirum") e antepenúltima ("Sanctus"). O modo como foram distribuídas pode sugerir que, ao armar e dispor as partes da música, Mozart a teria concebido objetivando obter a forma espelhada de duas grandes seções:

\begin{tabular}{|l|l|}
\hline Seções Iniciais e Intermediárias & Seções Intermediárias e Finais \\
\hline Introitus -16 & Lacrimosa -6 \\
\hline Dies Irae -6 & Domine Jesu -8 \\
\hline Tuba Mirum -4 & Hostias -8 \\
\hline Rex Tremendae -6 & Sanctus -3 \\
\hline Recordare -8 & Benedictus -14 \\
\hline Confutatis -9 & Agnus Dei -16 \\
\hline
\end{tabular}

A hipótese de que a composição contasse duas seções, subdivididas em seis subseções, poderia ser reforçada pelo fato de "Lacrimosa" (sétima) retoma e desenvolve o tema e o andamento da primeira, "Introitus". Seria razoável propor analogias entre a música e as letras, para comentar a disposição da peça. Dessa perspectiva, o Requiem poderia ser associado a um romance, dividido em dois livros, cada um com seis capítulos. Ele contém orações e diálogos entre as vozes, sob a forma de acordes ${ }^{330}$. Essas

\footnotetext{
329 "Mozart was the greatest master at mixing and coordinating topics, often in the shortest space and with startling contrast. The allegro of the first movement of his Prague Symphony, K. 504, 1786, is a panorama of topics, old and new, in which a change of subject occurs every few measures. The introduction is linked to the allegro by the subtlest of means. We hardly sense at first the change of tempo from adagio to allegro; the syncopation on two levels-the quarter- and eighth-notes in the first violins against the alla zoppa ("limping") quarter- and half-notes in the lower strings-clouds the rhythm; the singing melody is buried in the lower instruments while the harmony falters toward $G$, thanks to the $C^{\#}$. All this lends added brilliance to the fanfares that conclude the first period of the allegro, finally giving sharp profile to the key, melody, and rhythm".

330 A esse respeito, Arnold Schoenberg (2004, p. 22) recomendava que "Ao encadear acordes, é aconselhável que cada uma das quatro vozes (soprano, contralto, tenor e baixo, geralmente utilizadas
} 
personagens seriam acompanhadas por instrumentos convenientes à dicção elevada do gênero fúnebre: cordas, órgão, metais ${ }^{331}$ e madeiras apoiam diálogos ora vibrantes, ora melífluos - reforçados pelas pausas ou sinais de ligamento.

Quanto à disposição (dispositio) e performance (actio) $)^{332}$, o gênero réquiem se aproxima do sermão, prática letrada que também costumava ser dividida em várias partes, com fins pré-definidos ${ }^{333}$. A primeira subseção ("Introitus") funciona como Exórdio e subdivide-se em Adagio e Allegro. Transposta para o plano religioso, elas corresponderiam, ainda que parcialmente, à oscilação de afetos performadas pelo orador, diante dos fiéis - ora a introduzir o tópico com brandura, ora a assinalar contrapontos, quando expõe a quaestio do sermão.

Outro aspecto importante envolve o ambiente em que a peça seria apresentada. Quando compôs a obra, Mozart possivelmente teria vislumbrado sua execução em espaços relativamente amplos, perante razoável auditório (possivelmente, um funeral aberto ao público). Isso explicaria a presença de variadas vozes e instrumentos, reconhecidos por soar enérgica e nitidamente em espaços amplos. Em relevante estudo sobre as performances letradas e artísticas ao final do século XVIII, Kevin Barry (1987, p. 18) relativizava a hipótese de John Hollander de que “[...] o interesse imaginativo, reflexivo e especulativo em música terminara por volta de 1700 ". Barry salienta que escritores e poetas eram entusiastas e integravam a audiência de concertos musicais, durante o Setecentos. Samuel Taylor Coleridge, por exemplo, tinha admiração particular por Mozart, Beethoven, Palestrina e Purcell (1987, pp. 23-24).

\footnotetext{
para apresentar sequências harmônicas) não se mova mais do que o necessário", a fim de evitar "os grande saltos".

331 "The topic of horn call is, as Agawu notes, 'normally associated with announcements and opening gestures.'. But unlike the others discussed so far, this topic brings with it a distinctly more active harmonic environment, the motion from tonic to dominant and back again to tonic. As a result[,] the horn call adapts itself easily to a variety of other functions, including both cadential (Example 5b) and post-cadential" (CAPLIN, 2005, p. 119) - "A tópica do horn call está 'associada', como nota Agawu, 'ao modo dos anúncios e aberturas'. Mas diferentemente de outras, já tão discutidas, essa tópica traz um ambiente harmônico mais evidente, o deslocamento da [nota] tônica para a dominante e de volta para a tônica. Como resultado, o horn calls se adapta facilmente à variedade de funções, inclusive nas cadências e póscadências".

332 Lê-se na Retórica a Herênio (1997, pp. 74-75): “Há dois tipos de exórdio: o exórdio direto, que os gregos chamam prooímion, e o exórdio por insinuação, que denominam éphodos. O exórdio direto serve para lograr de maneira imediata que o ouvinte nos escute. Seu objetivo é conseguir que os ouvintes se mostrem atentos interessados e favoráveis".

${ }^{333}$ Vários tratados da Ars Praedicandi orientaram a disposição e pregação dos sermões durante a Idade Média, distribuídos em partes que variavam quanto ao número de partes em que deveriam ser divididos. Cf. James Murphy (1974, pp. 269-355) e Alcir Pécora (2008).
} 


\section{Elocução}

É frequente o emprego do antigo conceito de "dicção" 334 , mesmo nos estudos recentes sobre Literatura. Será possível dizer algo equivalente, em relação à Música? Em 1606, Joachim Burmeister (2017, p. 77) argumentou que:

[...] a música poética é a célebre parte da música que ensina como se deve escrever um poema musical, combinando os sons das melodias para construir uma harmonia ornada por diversos afetos, que constituem os períodos do discurso; essa harmonia visa a tocar o espírito e o coração dos homens, suscitando movimentos variados da alma.

Cento e sessenta e nove anos depois, James Harris (1765, p. 102) alertou para o fato de que: "A música, quando desacompanhada, só pode despertar afetos que rapidamente definham ou decaem, se não forem sustentados e alimentados pelas nutritivas imagens da poesia. Contudo, é preciso lembrar, nessa união, que a poesia sempre teve precedência; sua utilidade, assim como sua dignidade, é mais considerável”335. Para o gramático inglês, os vínculos entre a Música e a Poesia atendiam ao pressuposto de que a disposição e arranjo dos sons move as paixões do ouvinte, mas não se sustenta por maior tempo se não contar com as metáforas sugeridas pelos versos. Em um belo estudo sobre a Musica Poetica, Ferruccio Civra (2009, p. 41) salientou que:

Na realidade, toda a retórica musical reconduz à ideia primordial pitagórica da retórica como psicacogia e, nesse sentido, há de ser intensa: os afetos, com ou sem intervenção da palavra, são a natura de que a arte musical é a imitação; são o conteúdo ou significado principal do discurso. ${ }^{336}$

Naturalmente, sons e imagens são produzidos de diferentes modos, por músicos e poetas. Por isso, se quisermos ilustrar possíveis diálogos entre a música e as letras,

\footnotetext{
334 "Aqui pretendo que as palavras sejam entendidas de modo geral, uma vez que que há duplo entendimento delas; um que significa tudo pelo qual o discurso se interliga, como em Horácio: 'As palavras seguirão espontaneamente o assunto selecionado'. E outro, em que o verbo é parte da oração, como lego ('leio'), scribo ('escrevo'); evitando a ambiguidade, alguns preferiram dizer voces, 'vozes', locutiones, 'locuções' e dictiones, 'dicções'." (QUINTILIANO, 2015, Livro I, p. 93).

335 "Music, when alone, can only raise Affections, which soon languish and decay, if not maintained and fed by the nutritive Images of Poetry. Yet must it be remembered, in this Union, that Poetry ever have the Precedence; its Utility, as well as Dignity, being by far the more considerable".

336 "In realtà, tutta la retorica musicale è da ricondurre alla primordiale idea pitagórica della retorica come psicacogia e in questo senso ha da essere intensa: gli affetti, com o senza intervento della parola, sono la natura di cui l'arte musicale è l'imitazione, sono il contenuto o significato principale del suo discorso".
} 
pode ser produtivo estabelecer paralelos entre esse gênero musical e a tragédia. A seu modo, ambas as artes tratam de matéria relacionada ao destino, a finitude e o reconforto espiritual do homem. Aceita a analogia entre notas e palavras, poder-se-ia escutar, ler ${ }^{337}$ e interpretar o Requiem como discurso musical que privilegia a voz de personae que se expressam sós ou como parte de outras vozes. Em vários excertos, as vozes humanas conjugam melodias a harmonias, no que são enriquecidas pelos instrumentos.

A existência de numerosos timbres comprova tratar-se de uma composição a versar sobre matéria elevada, possivelmente concebida de modo a induzir a reflexão e estimular variadas paixões, da audiência, sobre a morte e o juízo final. A partitura mostra que Mozart havia escrito melodias, coincidentes ou não, para catorze timbres - dez deles produzidos por instrumentos (metais, madeiras, percussão e cordas); quatro, por vozes humanas, com duas intermediárias (Alto e Tenor) entre a mais aguda (Soprano) e mais grave (Baixo):

\footnotetext{
337 “Uma interpretação é plausível tanto quanto evite pretensões totalizantes - ou melhor, avizinha-se da totalidade sem contudo esmagar a obra o espaço multifário para outras aproximações. Visto em sua condição peculiar, a partir da perspectiva não menos singular do leitor, o texto necessita ser re-conhecido primeiramente em sua temporalidade, distante do universo onde se concretiza sua leitura extemporânea" (FURTADO, 1997, p. 31 - grifo meu).
} 


\section{REQUIEM}

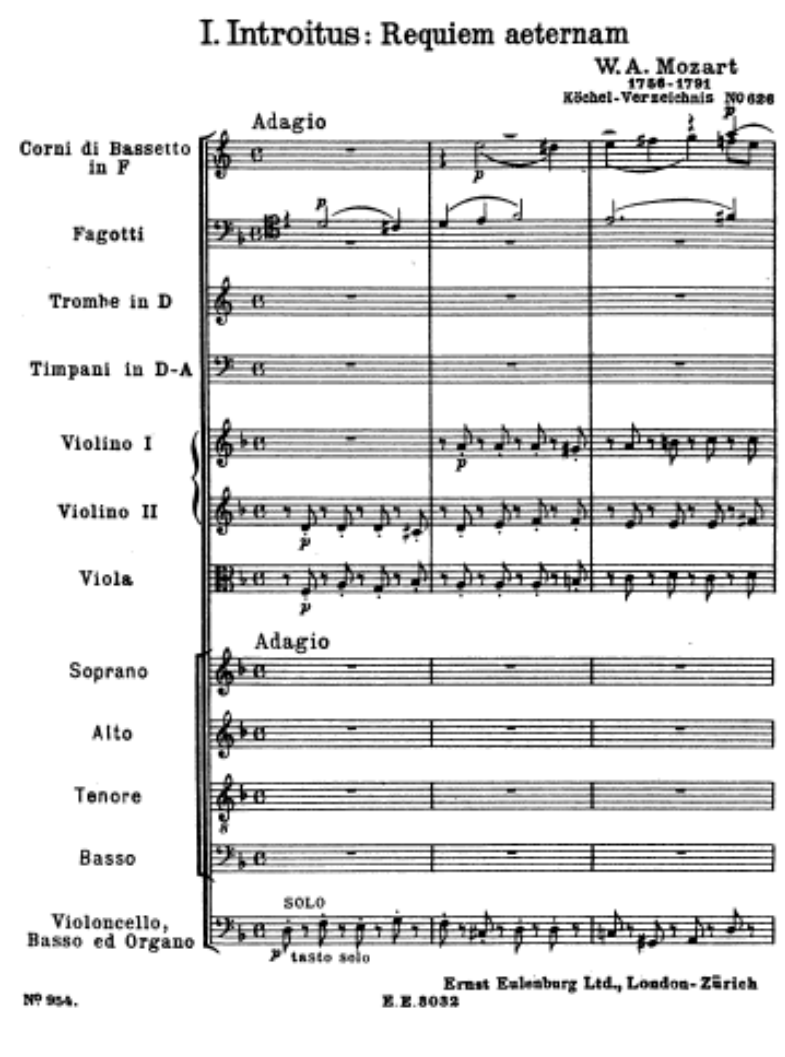

(MOZART, 1986, p. 1)

As vozes foram dispostas de modo a soar conjunta ou individualmente. Há momentos em que três delas, harmonizadas, reforçam a melodia principal (solo), o que confere maior volume e intensidade às seções em que isso acontece (MOZART, 1986, p. 3):

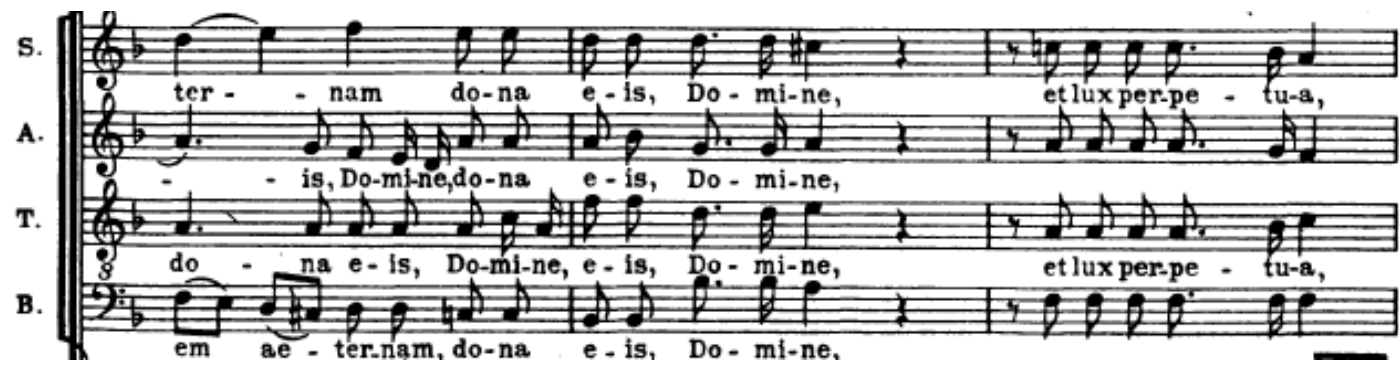

Em outros excertos, um grupo de vozes reproduz, compassos a frente, o desenho melódico das primeiras (MOZART, 1986, p. 2): 


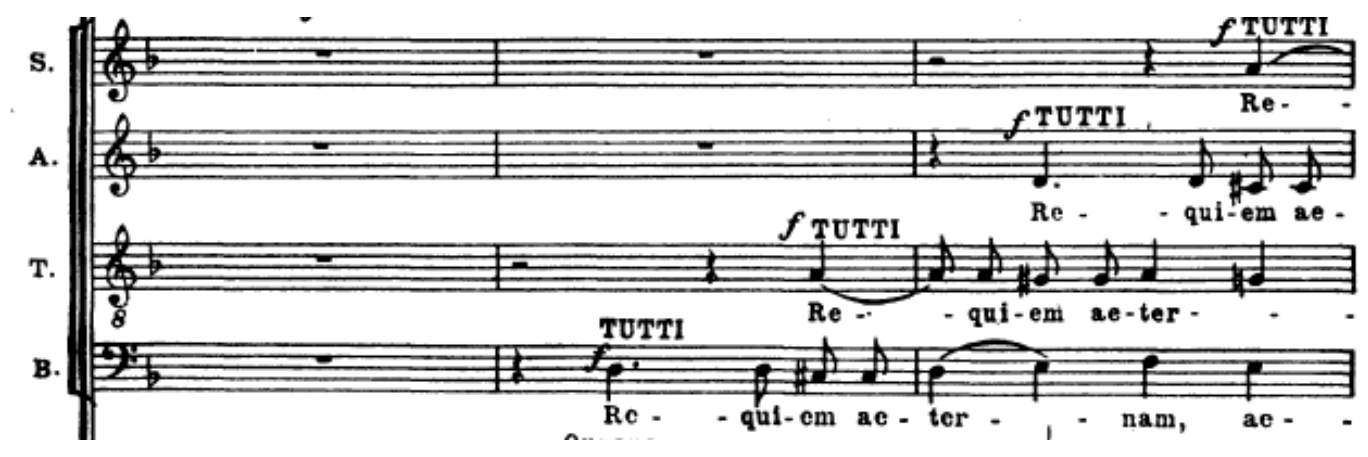

A combinação das vozes - Soprano, Alto, Tenor e Baixo -, que ora soam simultaneamente, ora alternadamente; ora em uníssono, ora mediante intervalos tonais, é uma das principais características do Réquiem. No "Introitus", analogamente ao primeiro capítulo de uma peça trágica, as vozes atuam como se estivessem a dialogar sobre a morte e eternidade. Não seria demasiado interpretar a disposição desses sons, performados sincrônica ou a-sincronicamente; em uníssono ou sob a forma de intervalos ${ }^{338}$ (terças, quartas, quintas, sextas, oitavas etc.), como procedimento análogo ao artifício empregado nos diálogos de personagens e falas reproduzidas pelos coros, nas tragédias gregas, durante a Antiguidade, a disputar as rédeas do destino.

No Requiem, há diversas passagens em que o Solo, executado por um ou mais cantores, precede compassos em que duas, três ou quatro vozes se combinam, como se mimetizassem diálogos entre uma ou mais personae e entes celestiais. Seria o caso de indagar se poderíamos associar as vozes masculinas com as dimensões debaixo do céu 339 - em alusão às hierarquias celestiais, terrenas ou infernais, que iam de Pseudo-

\footnotetext{
338 "Si je touche la corde $u t$, les cordes montées à son Octave $u t$, à la Quinte sol de cette Octave, à la Tierce mi de la double Octave, même aux Octaves de tout cela, frémiront toutes $\&$ résonneront à la fois; \& quand la corde seroit seule, première on distingueroit encore tous ces Sons dans sa résonnance. Voilà donc I'Octave, la Tierce majeure, \& la Quinte directes. Les autres Consonnances se trouvent aussi par combinaisons; [à] savoir, la Tierce mineure, du $m i$ au sol ; la Sixte mineure, du même mi à l'ut den haut; la Quarte, du sol à ce même ut; \& la Sixte majeure, du même sol au mi qui est au-dessus de lui" (ROUSSEAU, 1768, p. 115) - "Se eu toco a corda dó, as cordas elevadas até a sua oitava (Dó), à quinta (Sol) desta oitava, à terça $(\mathrm{Mi})$ da próxima oitava, inclusive as oitavas, todas vibrarão e soarão ao mesmo tempo; e quanto a corda estiver só, primeiramente distinguiremos todos esses sons em sua ressonância. Lá está a Oitava, a Terça Maior \& a Quinta direta. As demais Consonâncias também se encontram mediante combinações; a saber, a Terça menor, do Mi ao Sol; a Sexta menor, do mesmo Mi ao Dó superior; a Quarta, do Sol ao mesmo Dó; \& a Sexta maior, do mesmo Sol ao Mi posterior"

339 De acordo com João Vicente Ganzarolli Oliveira (2018, pp. 183-1840: "Aristóteles considerava os planetas seres inteligentes, intermediários entre o homem e Deus, Motor Imóvel no seu sistema cosmológico. Séculos depois, no auge do platonismo cristão em Bizâncio, Dionísio Aeropagita substituiu
} 
Aeropagita a Dante Alighieri -, o que reforçaria o destino infernal reservado aos maus (MOZART, 1986, p. 28):

s.

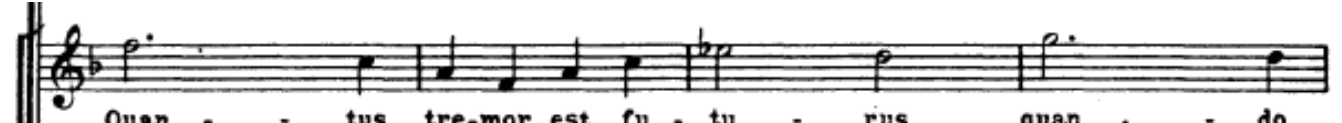

A.
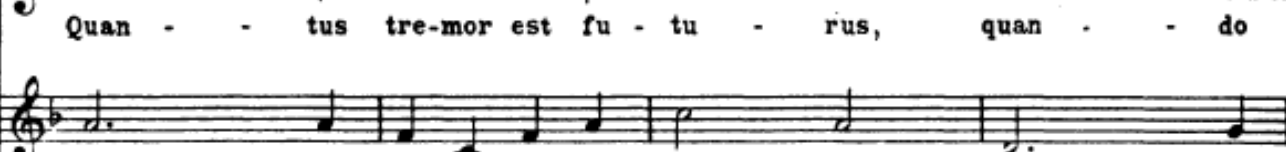

T.

Quan - - tus tre-mor est fu - ti - rus quan do

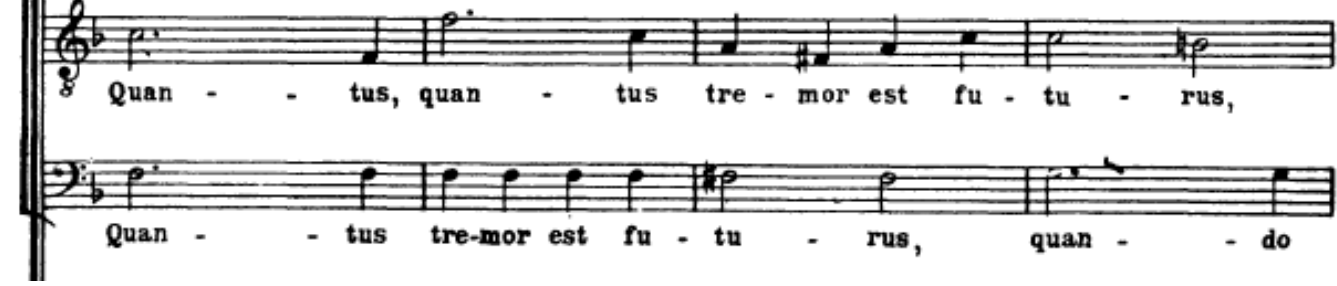

Além dos fraseados melódicos, harmonizados pelas vozes e instrumentos, chama atenção o arranjo das notas performadas pelos cantores. Em "Rex tremendae", ora eles executam as mesmas sílabas, que coincidem com diferentes notas, ora, diferentes sílabas reforçam os intervalos tonais, executados simultaneamente (MOZART, 1986, p. 50):

os planetas de Aristóteles pelos anjos de que fala a Bíblia. (...) Aristóteles preenche esse hiato ontológico com os astros; Dionísio o faz com os anjos: tal é o assunto central da sua obra sobre a hierarquia angélica, de influência incomensurável tanto em Bizâncio quanto na Europa ocidental. Isso fortalece a interpretação de Egon Joseph Wellesz, que aposta na analogia intencional (particularmente em Bizâncio) entre a música celeste, isto é, angélica, e a humana: a intenção era imitar 'os cantos divinos entoados pelos anjos do Céu'." 


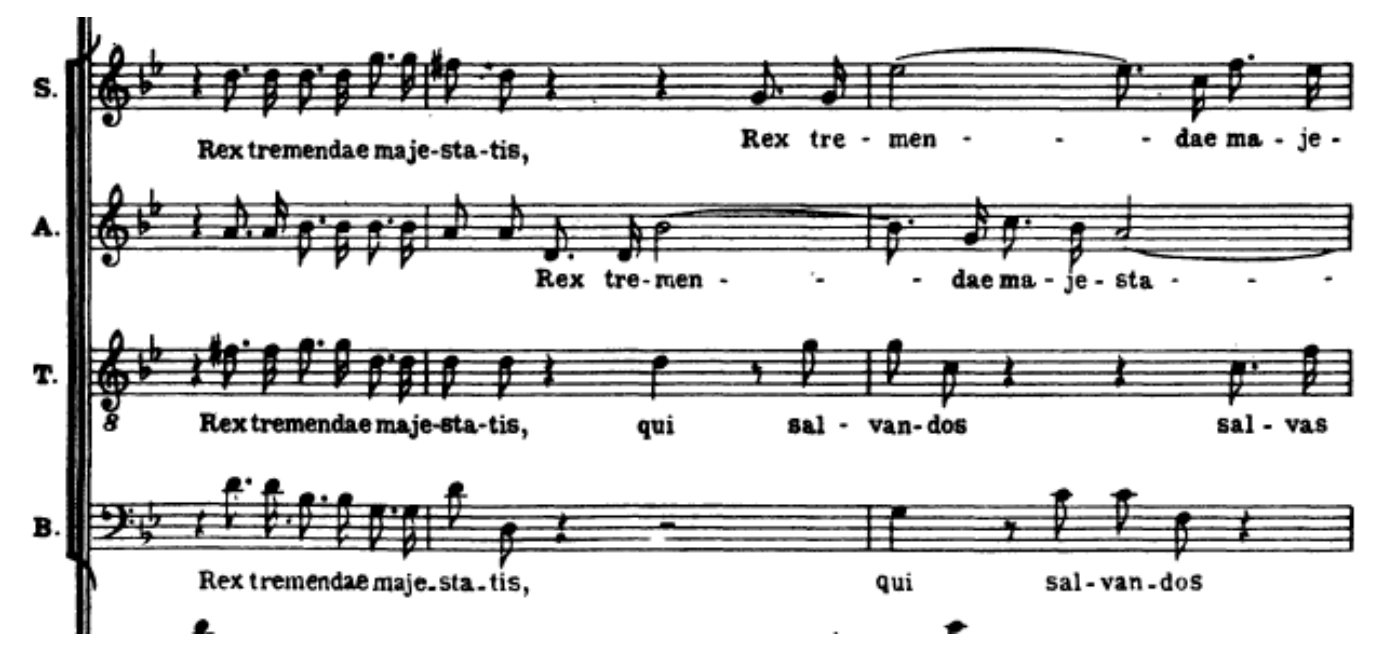

Na mesma subseção, as vozes masculinas reverberam as femininas com um compasso de diferença, em anaploche ${ }^{340}$, a evocar o cânone ${ }^{341}$ musical - artifício bastante utilizado no século XVII (MOZART, 1986, p. 53):

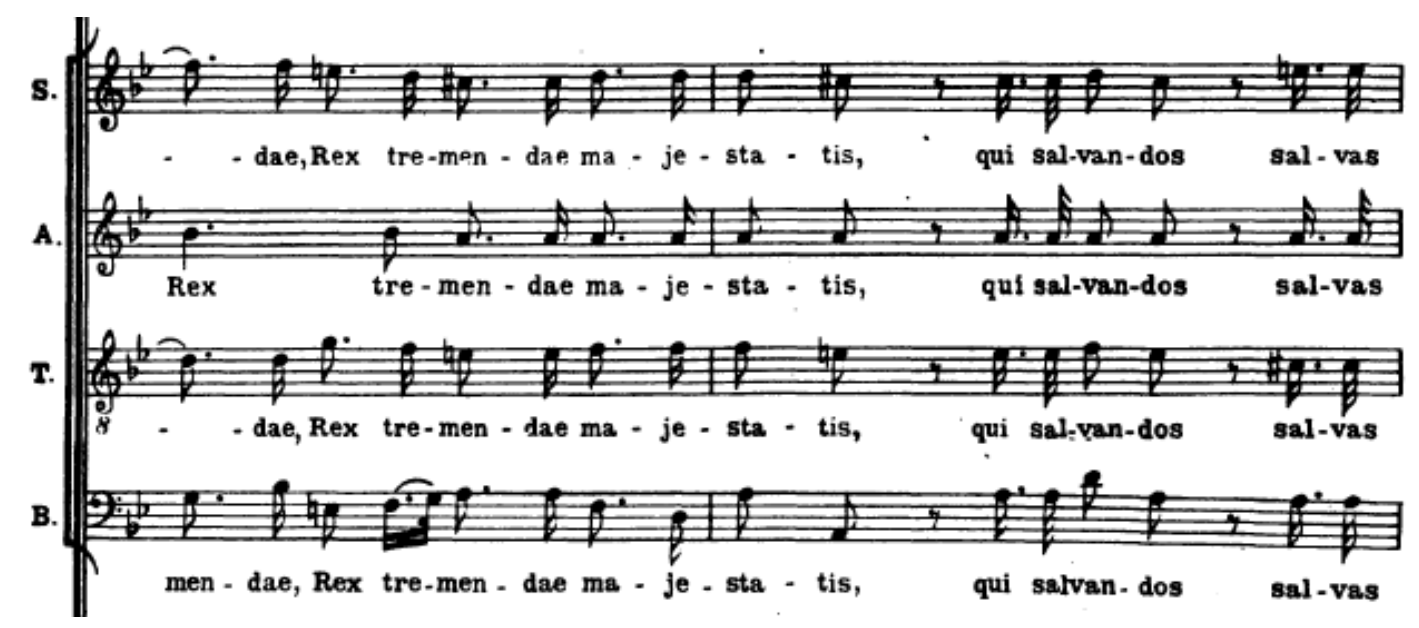

340 "Anàploche (gr. Anaploké = intreccio) è la repetizione frequente di una parola o di uno stesso concetto in segmenti sucessivi" (PERLINI, 2002, p. 21) - "Anaploche é a repetição frequente de uma palavra ou de um mesmo conceito em segmentos sucessivos".

341 “CANON, s, m. C'était dans la Musique ancienne une règle ou méthode pour déterminer les rapports des Intervalles. L'on donnait aussi le nom de Canon à I'Instrument par lequel on trouvait ces rapports, \& Ptolomée a donné le même nom au Livre que nous avons de lui sur les rapports de tous les Intervalles harmoniques. (...) CANON, en Musique moderne, est une sorte de Fugue qu'on appelle perpétuelle, parce que les Parties, partant l'une après l'autre, répètent sans cesse le même Chant (ROUSSEAU, 1768, p. 70) - "Cânone, sub., masc. - Na música antiga, era uma regra ou método que dizia respeito às correspondências entre os intervalos. Também se dava o nome de Cânone ao instrumento mediante o qual se produziam essas ligações. Ptolomeu atribuiu o mesmo nome às correspondências de todos os intervalos harmônicos no livro dele que possuímos. (...) Na Música moderna, Cânone é uma espécie de Fuga que denominamos perpétua, já que as partes, partindo umas após as outras, repetem sem cessar o mesmo canto". 
Recurso similar orienta os primeiros versos e notas de "Confutatis" (MOZART, 1986, p. 67):

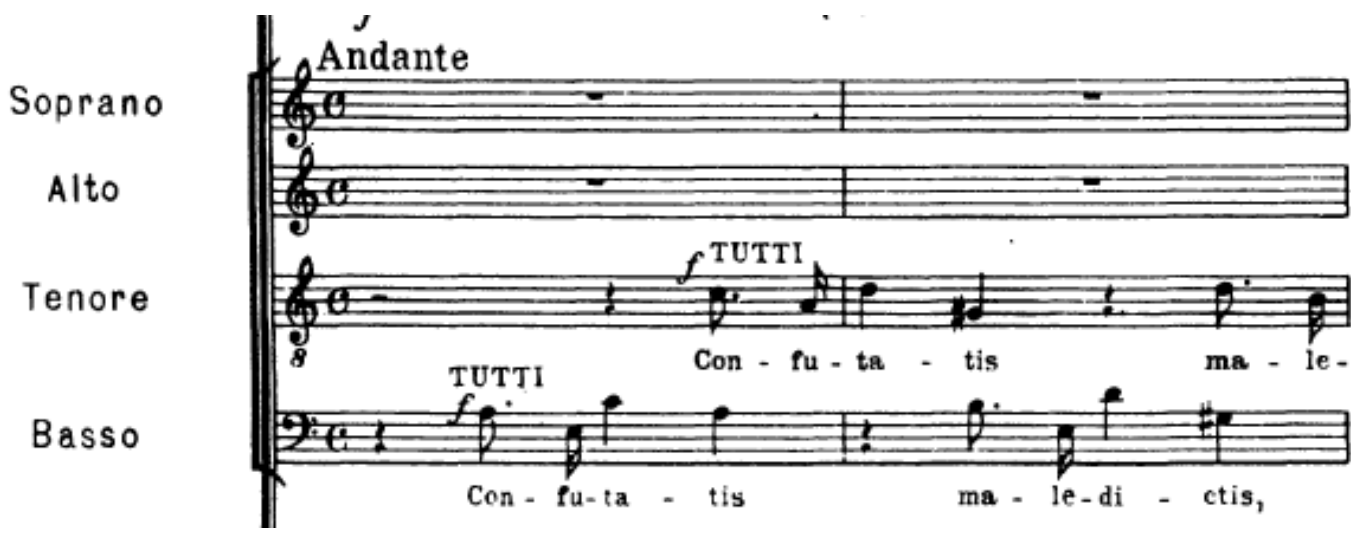

A segunda seção contém sensível variação, performada de modo sucessivo e alternado pelas quatro vozes, em que Soprano e Alto entoam "Voca, Voca-me, Voca-me cum benedcitis" ao longo de quatro compassos. A elas respondem, Tenor e Baixo com "Confutatis, maledictis, flammis a cribus ad dictis, com futatis maledictism, flammis a cribus addictis", pronunciadas em tempos diferentes, o que produz a simultaneidade de sílabas diferentes ${ }^{342}$, executadas pelas vozes masculinas em intervalos melódicos também variados (MOZART, 1986, p. 69):

${ }^{342}$ Na subceção "Confutatis", evidencia-se o uso de "sequências", por Mozart, ou seja, a "repetição exata de um segmento transposto a outro grau [nota]" (SCHOENBERG, 2004, p. 148), nas melodias performadas sequencialmente, em diferentes notas, por Baixo e Tenor. 

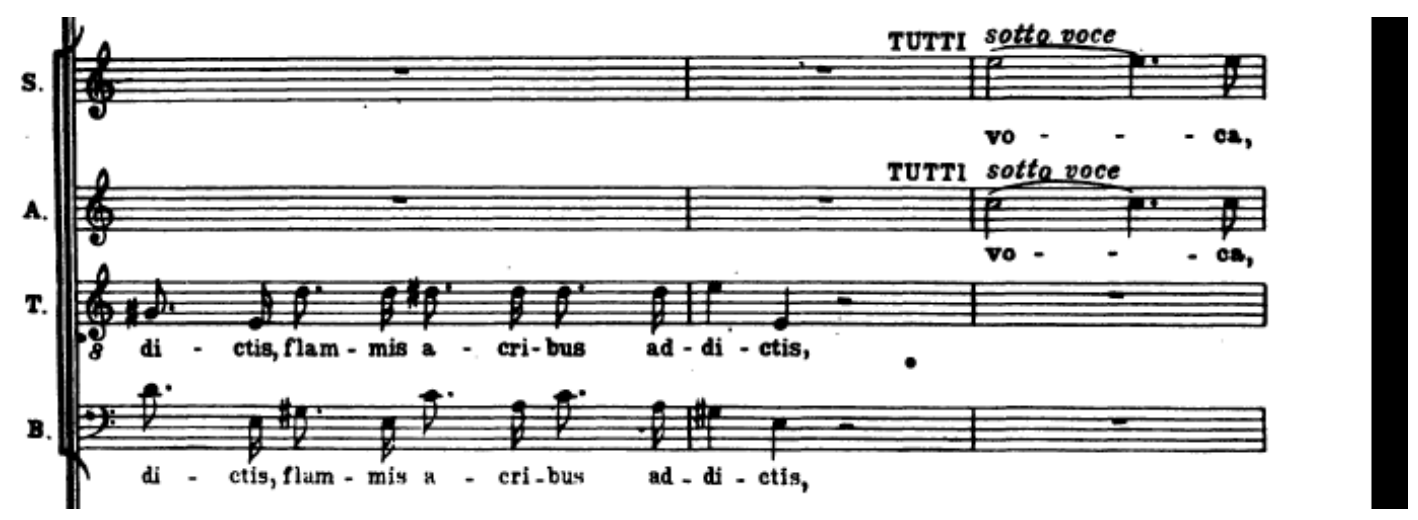

Enquanto as vozes femininas soam simultaneamente, em intervalo de terças, juntamente com primeiro e segundo violinos, em fraseado com reduzida quantidade de notas, as masculinas são executadas em oitavas, com reforço das semifusas executadas por violinos, viola, violoncelo, contrabaixo e órgão. O contraste entre a dicção amena (a cargo das vozes femininas, acompanhadas por poucos instrumentos) e a enérgica (a cargo das vozes masculinas, reforçadas por variados timbres) talvez explique o impacto provocado por esta seção, o que recorda os ensinamentos de Aristóteles, Cícero e Quintiliano, de que o orador deveria afetar o auditório, movendo as suas paixões. Segundo Aldrovandi (2019, p. 113):

[...] desde o século XVI, a noção de musica poetica inseriu a retórica na própria teoria musical. A ideia de pensar a forma da música por partes contrastantes também se associava a noções da arte oratória, especialmente à antiga ideia clássica de que o pensamento sobre a ordem das partes ajudava a "mover" as almas. Já no século XVI, fala-se de uma estrutura ternária de um discurso: exordium, medium e finis. E vários teóricos da música, a partir de então (como Poncio, Cerone, Praetorius, Mattheson), passam a analisar motetos, missas, madrigais etc., fazendo alusão a princípios da arte oratória.

Os versos da oração ("Voca-me" etc.) estão em correspondência com as notas e o fraseado melódico. As vozes graves condenam os malditos com vigor e velocidade. As vozes femininas suplicam mais lenta e brandamente pelo chamado de Deus. Não seria descabido associar Tenor, Baixo e os instrumentos que os acompanham sob a forma dos ostinati $^{343}$ com as profundas camadas do Inferno. Contraposta à condenação, a vocação

343 O ostinato pode ser definido como um padrão melódico ou rítmico repetido (RAWLINS, 2005). No filme Amadeus (1984), há uma cena impressionante, em torno dos ostinati, que reforça o brilhantismo do "genial" Mozart, a contrastar o seu raciocínio e extraordinária capacidade inventiva com a suposta 
é enunciada por notas angelicais e agudas, representadas mais lentamente pelas vozes femininas. Combinadas ao final, as quatro vozes sustentam a terceira seção melódica e são retomadas na seção contígua, "Lacrimosa" - seção que desenvolve o tema introdutório:

\section{Introitus: Requiem aeternam}

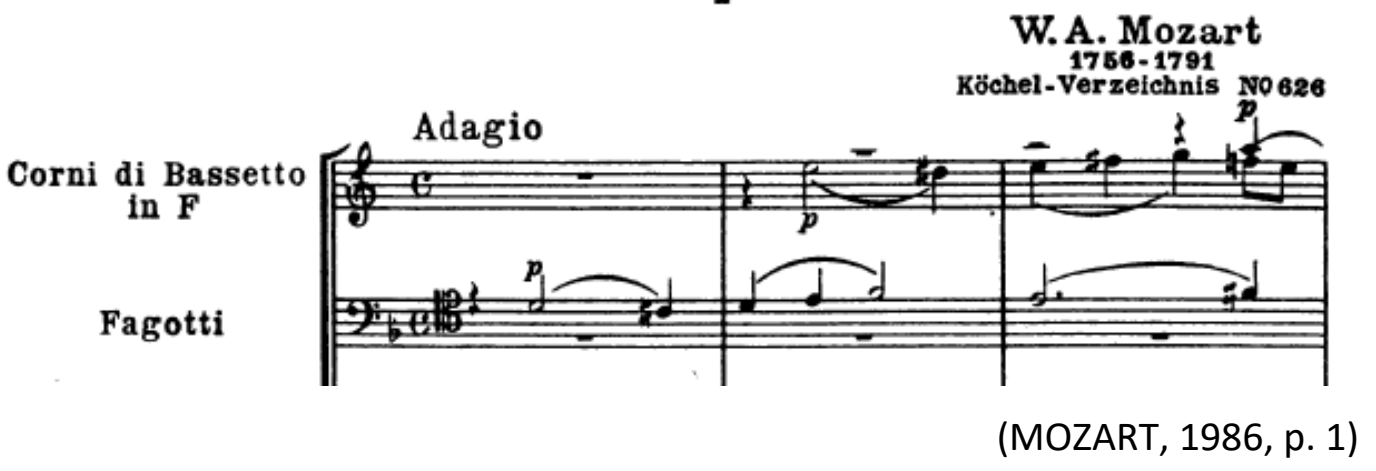

80

\section{Lacrimosa dies illa}

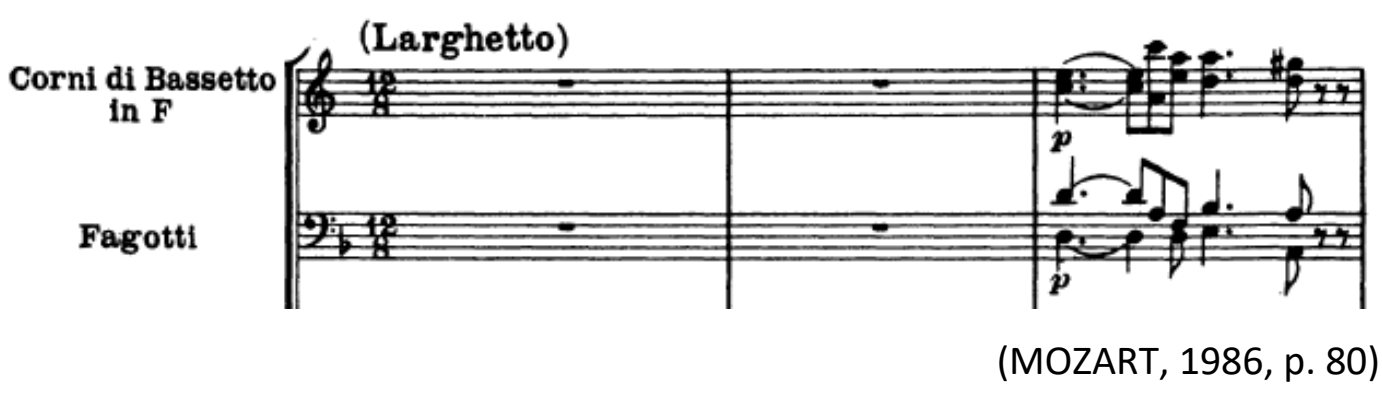

Poder-se-ia sugerir que "Confutatis" repousa sobre o tema danação versus salvação - parte e contraparte que resultam do julgamento dos mortos por Deus. As notas graves entram em analogia com as profundezas, em catábase ${ }^{344}$; as agudas parecem endereçar o pedido das almas ao céu, perfazendo uma anábase, sequência das notas em ascensão ${ }^{345}$. Por sua vez, "Lacrimosa", é uma breve oração a Deus para que

mediocridade de Salieri - que, nessa versão fantasiosa, tanto encomenda o Requiem ao músico, quanto colabora na transcrição da obra, até a morte (planejada) do compositor.

344 "Catàbasi (gr. katábasis = discesa) é uma frase musicale che, discendendo, esprime 'sosottomizione, umiliazione ed avvilimento'. È il contrario dell'Anábase" (PERLINI, 2002, p. 26) - "Cabatase é uma frase musical que, descendo, exprime 'submissão, humilhação e aviltamento'. É o contrário de Anábase".

345 "Anàbasi (gr. anábasis = salita), o Ascénsus (lat., idem), è uma liena musicale che, salendo, esprime 'esaltazione, ascensione o cose alte ed emitenti'." (PERLINI, 2002, p. 16) - "Anábase é uma linha musical que, de saída, exprime 'exaltação, ascensão ou coisa elevada e eminente'." 
Jesus tenha repouso - tema central da obra, que retoma a essência do gênero composicional - requies, requiem > descanso (DOTRO; HELDER, 2010, pp. 140-141).

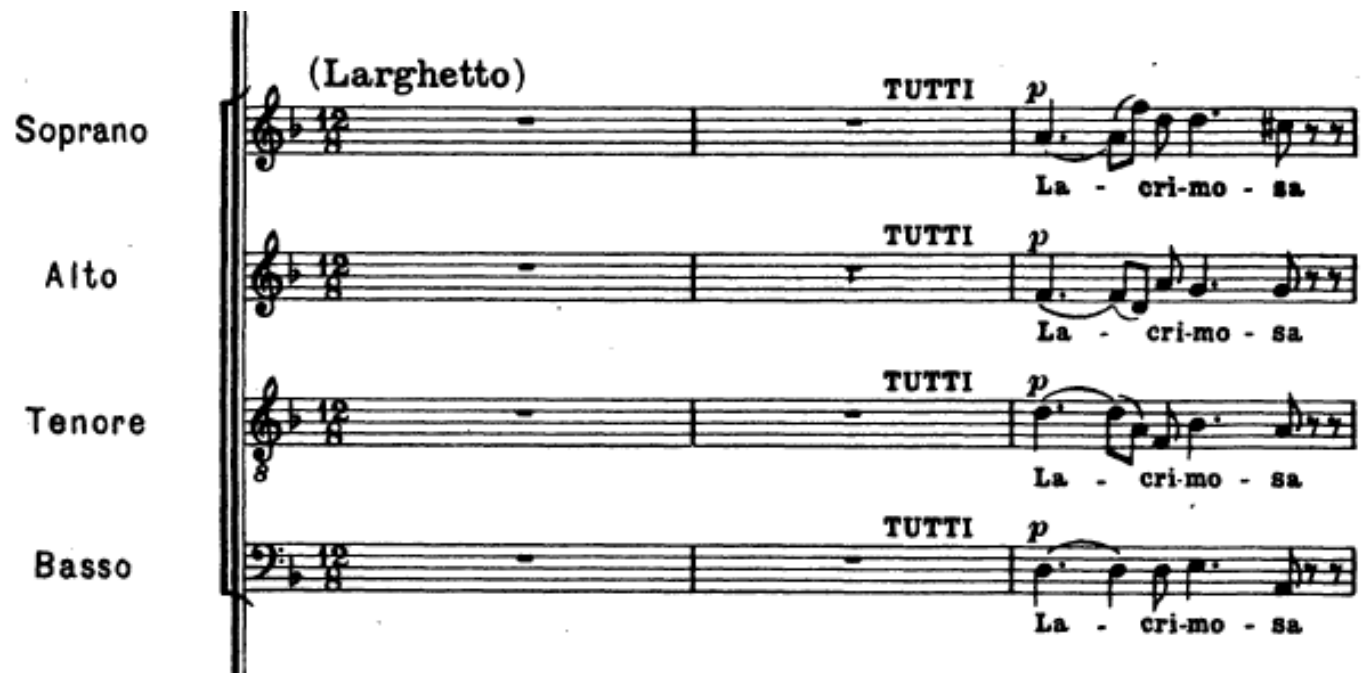

(MOZART, 1986, p. 80)

João Vicente Ganzarolli de Oliveira (2018, pp. 130-131 e 132) ressalta a importância da harmonia e sua correlação com as formas musicais:

Cícero falou de intervalos harmônicos nos quais os sons se misturam em obediência às leis da proporcionalidade. No início da era cristã, Plutarco fez referência ao uso de intervalos harmônicos de quarta e de quinta, na música vocal e também na instrumental. O neoplatônico Aristides Quintiliano (séc. III d.C.) adotou a ideia, também presente em Plutarco, de que as estações do ano relacionam-se entre si obedecendo às proporções que regem os intervalos sonoros sobre os quais se edifica a música das esferas: a primeira está para o outono na mesma proporção da quarta justa (4/3); em relação ao inverno, a proporção existente é a quinta justa (3/2); com o verão, relaciona-se mediante a oitava (2/1). Santo Agostinho, por sua vez, considerava a música um recurso para o entendimento da sociedade humana; segundo ele, no acordo razoável e moderado dos sons estaria um indicativo da cidade bem ordenada. (...) No século XIII - época em que a polifonia já estava legitimada tanto no âmbito sacro quanto no profano -, Tomás de Aquino escrevia: "As consonâncias musicais consistem em proporções numéricas aplicadas aos sons de acordo com a matéria".

Uma audição atenta ao Requiem de Mozart talvez reforce a leitura proposta nessas páginas. Dentre os aspectos relacionados à composição, haveria que se enfatizar as implicações do consórcio entre a melodia e a harmonia. A sugestão pode parecer óbvia, considerando estarmos diante de uma peça de estilo sublime, escrita do final do 
século XVIII, e concebida para vários instrumentos. No entanto, seria preciso levar em conta o que representam as notas (agudas, médias e graves) emitidas pelas vozes e o aspecto simbólico dos instrumentos (trombone, fagote, sacabuxa, violino etc.), que reverberava a disputa musical entre Apolo (lira) e Mársias (flauta), como demonstrou Emanuel Winternitz (1979). ${ }^{346}$

Obra de temática sacra, parece razoável interpretá-la como representação dos conflitos que obstruem o percurso gracioso e altivo da alma. O motivo é sublime, como demanda o gênero e salientam os instrumentos e vozes. O descanso final só virá após a vitória, obtida graças à conduta virtuosa sobre os vícios mundanos. Em correspondência com os instrumentos e vozes que simbolizam a dimensão celestial, as notas ascendentes sugerem o ascenso do espírito, a sugerir que o éthos, forjado em vida, recebeu a destinação adequada após o juízo dos mortos.

\footnotetext{
${ }^{346} \mathrm{Na}$ pesquisa de doutorado de Felipe Faglioni (2020, p. 1), em andamento, ele também se refere à importância da simbologia relacionada aos instrumentos musicais, desde a Antiguidade até o século XVIII. Claudio Monteverdi e Jean-Baptiste Lully, dentre outros, fizeram "[...] uso dos instrumentos musicais e seus simbolismos como ferramenta retórica em obras do início do século XVII (...) - palco para acontecimentos-chave no desenvolvimento da construção (...) e sua aplicação no repertório daquela época, bem como de posteriores".
} 


\section{Referências}

\section{Partituras}

MOZART, Wolfgang Amadeus. Requiem. New York: Dover Publications, Inc., 2018.

MOZART, Wolfgang Amadeus. Requiem [Köchel-Edition 626]. Zurich: Ernst Eulenberg Ltd., 1986.

\section{Estudos}

AGAWU, Kofi. Music as Discourse: Semiotic Adventures in Romantic Music. Oxford: Oxford University Press, 2009.

ALDROVANDI, Leonardo. Música e Mimese. São Paulo: Perspectiva, 2019.

BARROS, Cassiano de Almeida. Fundamentos teológico-políticos da Musica Poetica alemã. Revista Vórtex, Curitiba, 2020, 29p. [no prelo]

A Lógica da Expressão Musical no Classicismo: uma Revisão dos Tratados de H. C. Koch. Per Musi, Belo Horizonte, pp. 1-16, 2018.

BARRY, Kevin. Language, Music and The Sign: A study in aesthetics, Poetics and Poetic Practice from Collins to Coleridge. Cambridge: Cambridge University Press, 1987.

BARTEL, Dietrich. Musica Poetica: Musical-Rhetorical Figures in German Baroque Music. Lincoln: University of Nebraska Press, 1998.

BENNETT, Roy. Uma Breve História da Música. Trad. Maria Teresa Resende Costa. Rio de Janeiro: Zahar, 1986.

BLAIR, Hugh. Lectures on Rhetoric and Belles Lettres. Carbondale: Southern Illinois University Press, 2005.

BOWLES, William Lisle. The Poetical Works of William Lisle Bowles, Vol. 1. Edinburgh: James Nichol, 1815.

BRANDOLINI, Raffaele. On Music and Poetry. Trad. Ann E. Moyer; Marc Laureys. Tempe: Arizona Center for Mediaeval and Renaissance Studies, 2001.

BURMEISTER, Joachim. Poétique Musicale suivi de David Chytraeus - De La Musique. Trad. Agathe Sueur; Pascal Dubreuil. Paris: Rhutmos, 2017.

CAPLIN, William E. On the Relation of Musical Topoi to Formal Function. EighteenCentury Music, v. 2, n. 1, 2005, pp. 113-124. 
CAVINI, Maristella Pinheiro. A Morte o Sentimento Místico Humano: Dramaturgias Musicais Contidas no Réquiem de Mozart. Anais do III Fórum de Pesquisa Científica em Arte. Curitiba: Escola de Música e Belas Artes do Paraná, 2005, pp. 212-221.

CIVRA, Ferruccio. Musica Poetica: Retorica e Musica nel Periodo dela Riforma. Torino: Libreria Musicale Italiana Editrice, 2009.

CURZON, Henri de. Lettres de W. A. Mozart. Paris: Librairie Hachette, 1888. [PDF]

DOTRO, Ricardo Pascual; HELDER, Gerardo García. Dicionário de Liturgia. Trad. Gilmar Saint'Clair Riberiro. São Paulo: Edições Loyola, 2006.

ELIAS, Norbert. Mozart: Sociologia de um Gênio. Trad. Sergio Goes de Paula. Rio de Janeiro: Zahar, 1995.

FAGLIONI, Filipe. Instrumentos de sopro de madeira como alegoria retórica na música europeia do século XVIII. Tese de Doutorado. São Paulo, ECA/USP, 2020 [em andamento].

FURTADO, Joaci Pereira. Uma República de Leitores: História e Memória na Recepção das Cartas Chilenas (1845-1989). São Paulo: Hucitec, 1997.

HANSEN, João Adolfo. Categorias Epidíticas da Ekphrasis. Revista USP, São Paulo, n. 71, 2006, pp. 85-105.

Autor. In: JOBIM, José Luis (org.). Palavras da Crítica: Tendências e Conceitos no Estudo de Literatura. Rio de Janeiro: Imago, 1992, pp. 11-43.

HILBERATH, Bernd Jochen. Doutrina da Graça. In: SCHNEIDER, Theodor (org.). Manual de Dogmática, Vol. II. 5a ed. Trad. Ilson Kayser; Luís Marcos Sander; Walter Schlupp. Petrópolis: Vozes, 2001.

HINDLEY, Geoffrey (ed.). The Larousse Encyclopedia of Music. 14a ed. Twickenham: Hamlyn Publishing, 1986.

LANDON, H. C. Robbins. O Último Ano de Mozart: o Esplendor da Música na Vida Cultural da Europa ao Final do Século XVIII. Trad. Newton Goldman. Rio de Janeiro: Nova Fronteira, 1990.

LEESON, Daniel N. Opus Ultimum: the Story of the Mozart Requiem. New York: Algora Publishing, 2004.

LUCAS, Mônica. Johann Mattheson e o Ideal do Músico Perfeito. Per Musi, Belo Horizonte, n. 35, 2016, pp. 100-123. 
Relações entre Música e Linguagem na Segunda Metade do Séc. XVIII: A Allgemeine Geschichte der Musik de Johann Nikolaus Forkel. Revista Música Hodie, 9 (3Esp), 2013, pp. 13-27.

Imitação e Linguagem na Música Instrumental Europeia na Segunda Metade do Século XVIII. Relatório de Pós-Doutorado. São Paulo: FFLCH/USP, 2008. [Inédito]

MARQUES, Pedro. Arcádia Melodiosa no Brasil. Remate de Males, Campinas, n. 371, pp. 59-82.

OLIVEIRA, João Vicente Ganzarolli de. Ensaios sobre a Música Polifônica: Vozes que Iluminam o Ocidente. Rio de Janeiro: Editora UFRJ, 2018.

OLIVEIRA, José Custódio de. Tratado do Sublime de Dionísio Longino. Lisboa: Imprensa Nacional-Casa da Moeda, 1984.

PÉCORA, Alcir. Teatro do Sacramento: a Unidade Teológico-Política dos Sermões de Antônio Vieira. 2a ed. Campinas: Editora Unicamp; São Paulo: Edusp, 2008.

PERLINI, Silvano. Elementi di Retorica Musicale: il Texto e la su Veste Musicale nella Polifonia del '500 - '600. Milano: Casa Ricordi, 2002.

QUINTILIANO, Marcus Fabius. Instituição Oratória, T. I, Livro I. Trad. Bruno Fregni Bassetto. Campinas: Editora Unicamp, 2015.

RATNER, Leonard G. Classic Music: Expression, Form and Style. New York: Schirmer Books, 1980.

RAWLINS, Robert; BAHHA, Nor Eddine. Jazzology: The Encyclopedia of Jazz Theory for All Musicians. Londres: Hal Leonard Corporation, 2005.

RETÓRICA a Herenio. Trad. Salvador Núñez. Madrid: Gredos, 1997.

ROUSSEAU, Jean-Jacques. Dictionnaire de Musique. Paris: Chez la Veuve Duchesne, Librairie, 1768. [PDF]

SCHOENBERG, Arnold. Funções Estruturais da Harmonia. Trad. Eduardo Seincman. São Paulo: Via Lettera, 2004.

STRAVINSKY, Igor. Poética Musical (em 6 leições). Trad. Luiz Paulo Horta. Rio de Janeiro: Zahar, 1996.

WILLIAMS, Raymond. Arte. In: Palavras-Chave [um Vocabulário de Cultura e Sociedade]. Trad. Sandra Guardini Vasconcelos. São Paulo: Boitempo, 2007, pp. 60-62.

WINTERNITZ, Emanuel. Musical instruments and their symbolism in Western art: studies in music iconology. New Haven: Yale University Press, 1979. 